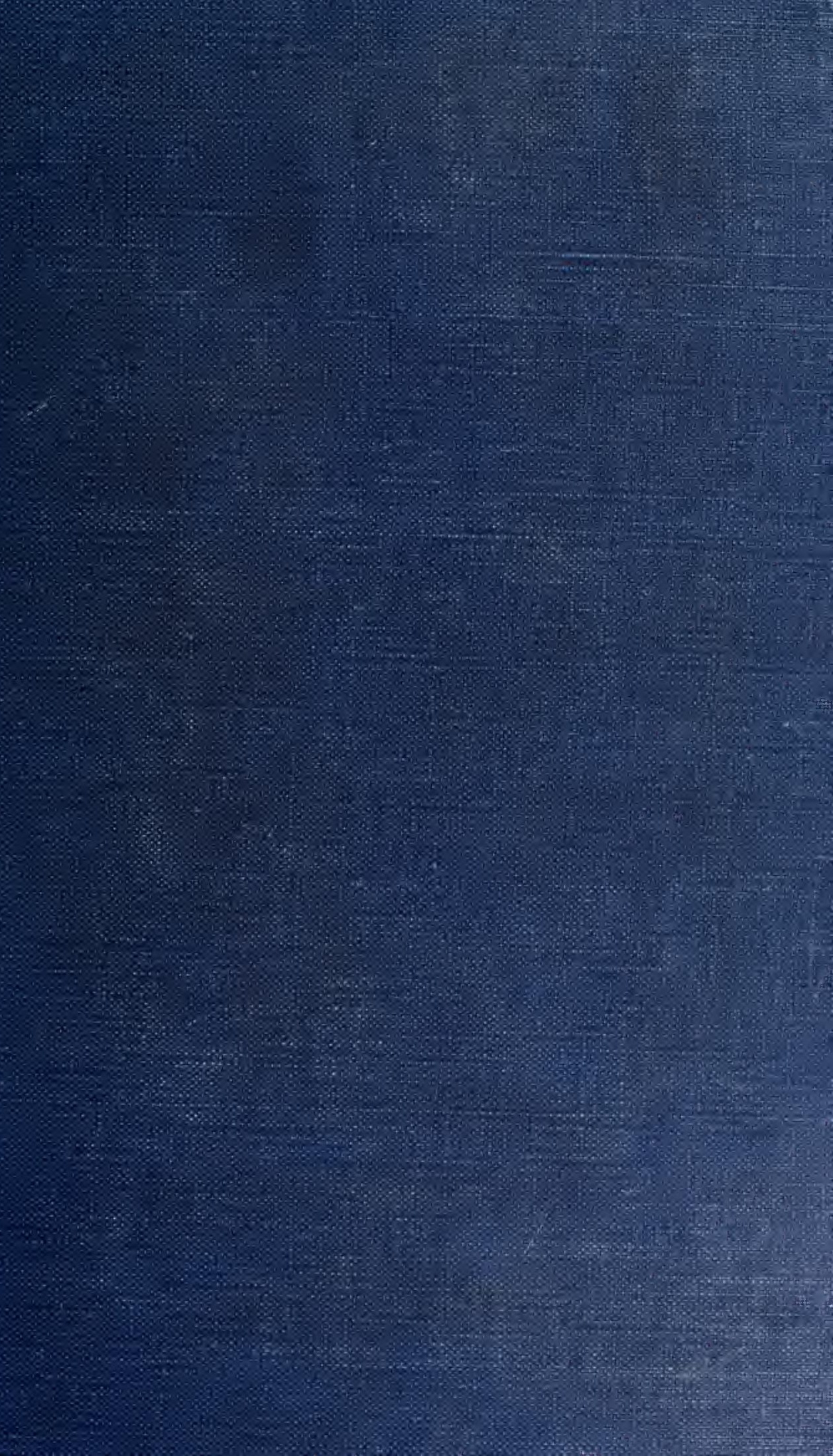



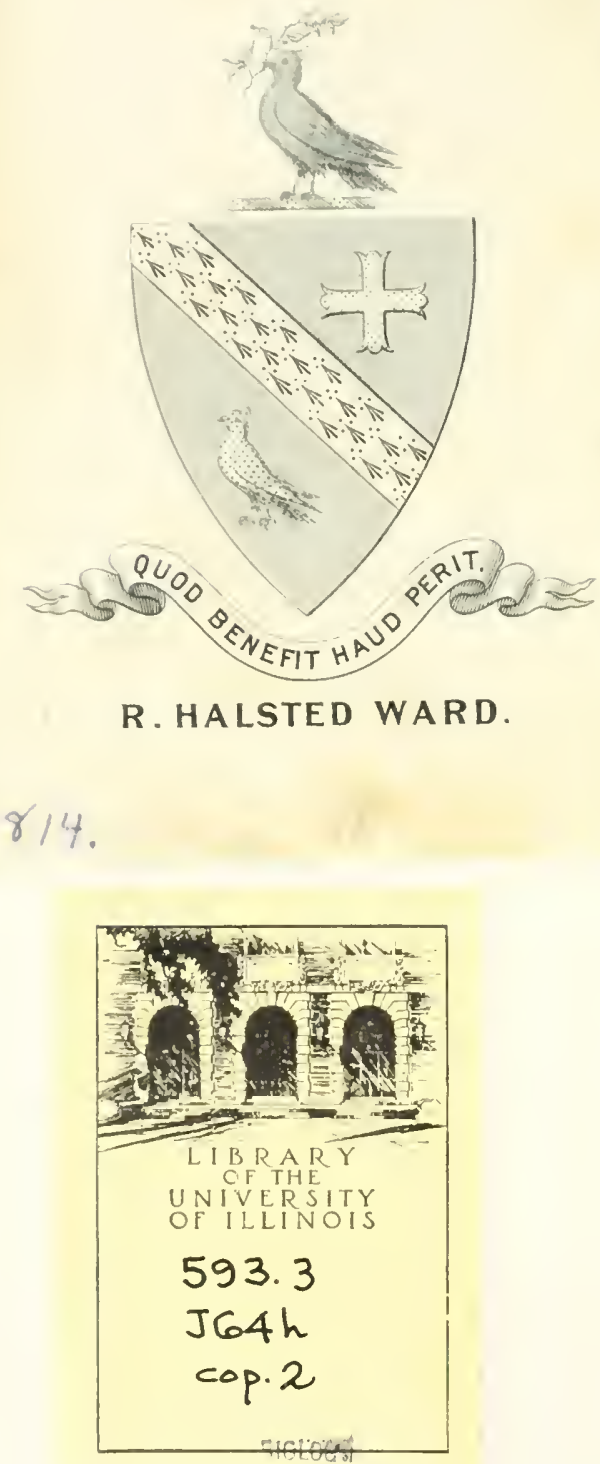
The person charging this material is responsible for its return on or before the Latest Date stamped below.

Theft, mutilation, and underlining of books are reasons for disciplinary action and may result in dismissal from the University.

UNIVERSITY OF ILLINOIS LIBRARY AT URBANA-CHAMPAIGN

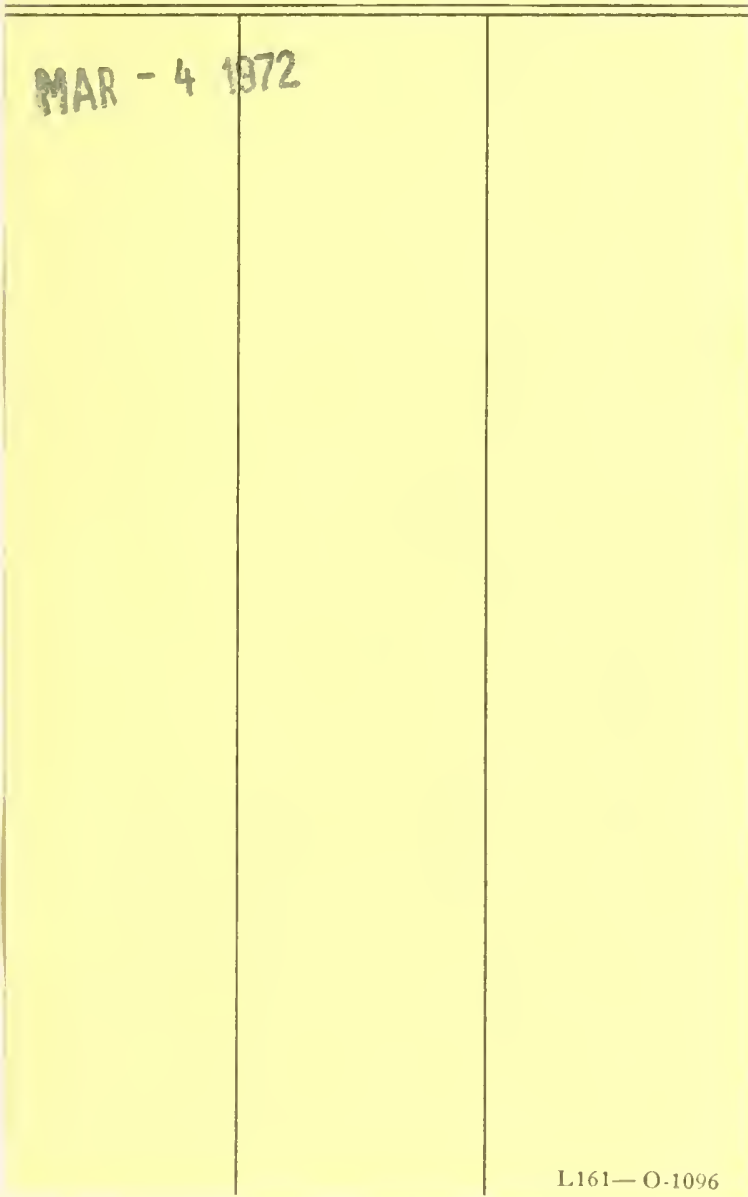


Digitized by the Internet Archive in 2011 with funding from University of Illinois Urbana-Champaign 


\section{A \\ HISTORY}

OF

\section{BRITISH SPONGES AND}

\section{LITHOPHYTES}

$\mathrm{BI}$

\section{GEORGE JOHNSTON, M. D., Ens.}

Fellow of the Royal College of Surgeons, Extraordinary Member of the Foyal Mcdical, and Corresponding Member of the Mcdieo-Chirurgical Socicties of Edinburgh ; Coriesponding Member of the Zoological Socicty of London; IIonorary $\mathbf{M} \mathrm{cmber}$ of the Royal Zoological Society of Ireland, of the Dublin Natural History Society, of the Natural History Society of Newcastlc-12pon-Tyne, of the Devon and Cornwall Natural llistory Society, of the Literary and 'hilosophical Society of St Andrews. and of the Trucedside Physical Society.

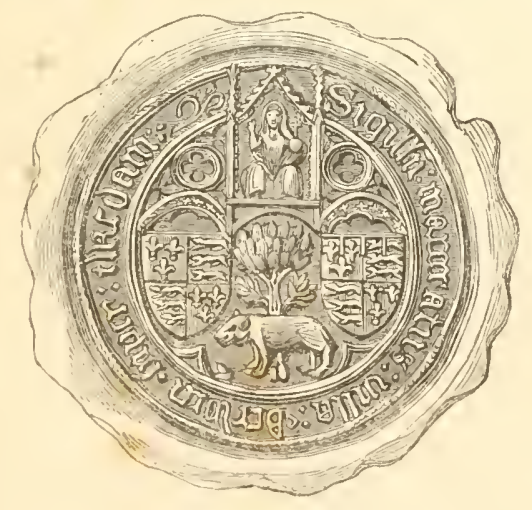

14. H. IIZARS, EDINBYRGII:

S. HIGHLEY. 3:2, FLEET STREET, IONDON; IND W. CURRY, JUN. AND CO, DUBLIN. 
PRINTED BY JOHN STARK, EDYNBURGH. 


$$
\begin{aligned}
& 593.3 \\
& J 64 h \\
& \text { Top. } 2
\end{aligned}
$$

THIS VOLUME

IS AFFECTIONATELY DEDICATED

BY HER HUSBAND

THE AUTHOR. 


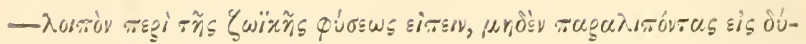

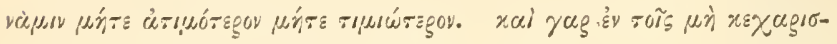

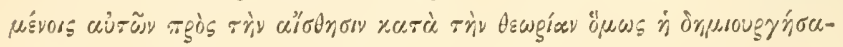

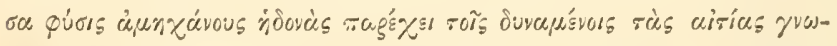

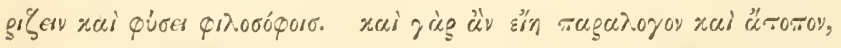

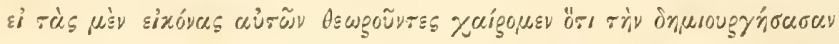

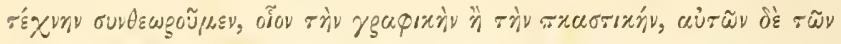

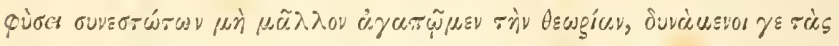

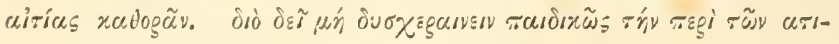

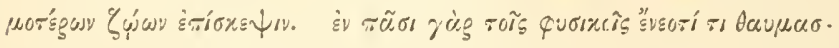

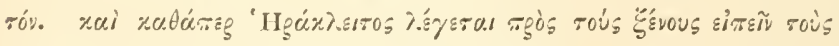

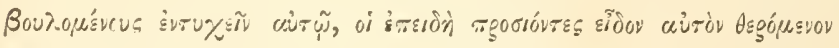

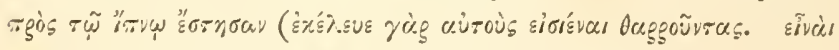

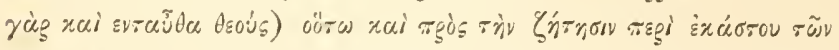

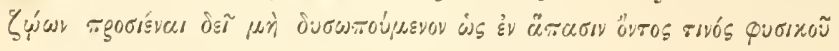

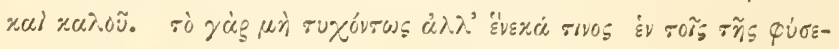

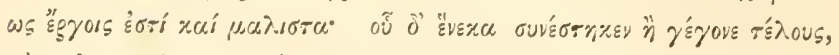

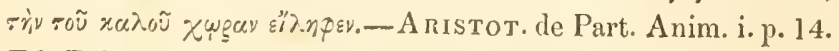
Ed. Bekker. 


\section{PRE F A E}

This work may very properly be considered as a supplement to my History of British Zoophytes. From my correspondents I learned that such a work was expected from me, and I was the more easily induced to undertake it from a belief that no other naturalist was likely to devote his time to illustrate a comparatively limited and isolated class of organized beings, obscure in character, and possessed of less interest than attaches to almost every other. The class may be said to oceupy at present a piece of debateable land, lying between the confines of the two organic kingdoms, - too poor and barren to be an object of contest with the subjects of either, and readily relinquished to the occupation of any eccentrie borderer who may find his pleasure in cultivating an intimacy with its rnde tenantry. This is not an easy task, for there is so much that is common to them, and cach adapts itself so readily to circumstances and assumes a new mask, that it requires a tact, to be gained only by some experience, to recognize them under their guises; while we labour, perhaps in vain, to devise phrases which shall aptly pourtray to others the characteristics of objects that have no fixed shape, and whose distinctive peculiaritics almost cheat the cyc. 
The physiology of the sponges has been fully elucidated by the industry and talent of Professor Grant; and Mr J.S. Bowerbank lias entered on an investigation of their minute and varied anatomy which will probably lead to a new and more stable arrangement of the class. My aim has chietly been to make myself acquainted with the variety of species which inhabit the shores of Britain; and to enable others to obtain, with comparative facility, the same acquaintance with them is the object of this volume. For this purpose I have in general added to my own account of the species, the original descriptions of them given by other authors, more especially by Colonel Montagu; and I have illustrated these verbal delineations with a series of portraits drawn from life, and resembling the originals as closely as the pencil of my wife could make them. But these representations will only lead to error if due allowance is not made, in the comparison of them with specimens, for those differences which Nature has herself impressed on every individual, - no two specimens of any species being ever found exactly alike in external figure; and to represent their minute, albeit specifical, differences of texture is sometimes impossible. Colonel Montagu felt this difficulty so strongly that he has given figures only of those species "which possess sufficiently strong specific characters to be defined by the pencil."

It is, I think, Sir James E. Smith who dwells so pointedly on the pleasure that a naturalist has in sharing his discoverics and his specimens with other naturalists of congenial dispositions and pursuits; and, to judge from my own experience, there are many eager to participate in this pleasure. With a liberality and frankness which it is easy to 
praise, and difficult to imitate, specimens and communications have been sent from every side of our island with the solc object of enabling a stranger to the great majority of his correspondents to render this history of our native Sponges and Lithophytes more complete and accurate than it could otherwise lave been made. The lindness of my Irish friends is characteristic. William Thompson, Esq. of Belfast, not only entrusted to me a large collection of Irish sponges made by limself, but he borrowed others for my use from R. Ball, Esq. and Dr Drummond, and he was the means of procuring for me an opportunity of examining the collection of the late Mr 'Templeton, without which the species mentioned by that most worthy naturalist could not have been ascertained. To Dr Scouler of Dublin I am largly indebted for another valuable collection of Irish sponges gathered principally by Mr. William M'Colla, one of those observant men, of the rank of Crabbe's friend the "Weaver," * who are led by a keen love of nature in her various productions to pursue their study amidst obstructions and disadvantages which would fray away less entlusiastic spirits. Mr Arthur H. Hassall, who I claim as my pupil in zoophytology, and likely ere long to surpass his master therein, also sent to me several sponges from Dublin Bay and other localities; and my talented friend Mr Edward Forbes gave me the specimens which he had dredged on the shores of the Isle of Man. Mr Bean of Scarborough, ever on the watch to oblige naturalists less

" "There is my friend the Weaver, strong desires Reign in his breast; 'tis beauty he admires; See! to the shady grove he wings his way, And feels in hope the raptures of the day."

The Borough, Letter viii. 
rich in species than liimself, sent such sponges and lithoplytes as heconsidered to be rare or undescribed, from the coast of Yorkshire; I received many others from the shores of the south of England from Mr J. C. Bellamy, the anthor of the "Natural History of South Devon ;" and from my much respected friend the Rev. David Landsborough of Stevenston in Ayrshire those which occur on the western coast of Scotland eame uncalled for. For assistance of a similar kind I must likewisc acknowledge my obligations to Miss Ellen Forster of Teignmonth, Dr Coldstream of Leith, Mr Embleton, Surgeon, of Embleton, the Rev. Dr Fleming of Aberdeen, Dr P. W. Maclagan, Mr T. G. Rylands of Bewsey House, near Warrington, Mr William Jackson Jun., Dundee, and Mr Alder of Newcastle.

I have done my best to arrange and describe the materials thus furnished me, but there is no affectation of modesty whon I express myself dissatisfied with myown performance; and it would give me unfeigned pleasure to be able to assure my readers that an abler hand would soon dispossess me of this field of my choice and occupancy. Naturalists are looking to Mr J.S. Bowerbank for much novel discovery relative to the structure and functions of this hitherto neglected tribe; and the descriptions which he lias given in this volume of Paeliymatisma Johnstonia and of Dysidea fragilis are so excellent in every respect, that it will be a matter of regret should this eminent naturalist decline to publish a history of the class in general. To him I am under deep obligations for assistance whieh he has given with an alacrity and kindness that tempted to very frequent ap-plications for it.

For much kint aid, more particularly in drawing up the 
Latin Synopsis of the species, I have to thank my friend the Rev. Thomas Riddell, A. M. Vicar of Masham in Yorkshire.

And now methinks this preface cannot be concluded better than by a translation of the passage from Aristotle which has been chosen for my motto :-

"We now proceed to speak of the nature of animals, not willingly omitting any part, however mean it may appear: for though many things among them have no charms for the bodily senses, yet notwithstanding even there creative Nature has unspeakable delights in store for those philosophic minds which can investigate and distinguish the canses of their formation. For it would be a strange paradox that we should find pleasure in viewing their figured representations, because we then contemplate the creative art of the painter or sculptor, and should not be still more gratified with the consideration of the natural configurations themselves, especially when we are able to perceive their causes. Therefore we must not be offended childishly with the examination of those animals which are held in no honour, for in all natural objects there is somewhat worthy of admiration : and like as it is related of Heraclitus, that he accosted some strangers who came to visit him, but who stopped short, when as they approached, they saw him warming himself at an oven_-' come in boldly,' said he, ' for bere also are the Gods'-so must we enter on the investigation of each individual animal without any feelings of disgust, inasmuch as in every one some beautiful provision of $\mathrm{Na}$ ture exists. For that nothing is by chance, but for some end, is the character of all the works of Nature: and the fitness of each part to the end for which it is designed occupies the place, and is entitled to the name, of Beauty." 
"In mediis morbis ipse versor;

mihi autem in his exercitiis periculosis occupato interdum occurrunt quædam in rerum naturâ nova : atque hæc equidem animi et delectationis causâ obiter notare soleo, et posteris libenter indicarem." M. LIster. 


\section{CONTENTS.}

General view of the structure and physiology of

Sponges, -
Their varions structures,
Their habitat, -


Opinions of Link

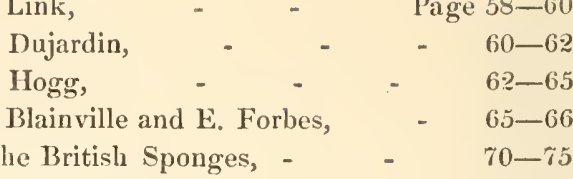

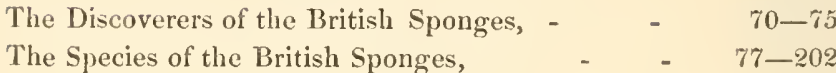

Character of the class Amorphozoa, _ _ _ $\quad$ - 78

Synopsis of its Genera, - _ . $\quad$ - 79

The genus Tethea and its species, _ _ $\quad$ - $81-87$

Halichondria and its species, _ $\quad$ s8-148

Spongilla and its species, $\quad$ - $\quad 149-163$

Spongia and its species, _ _ $\quad$ - 164-171

Grantia and its species, _ $\quad 172-184$

Duseideia and its species, _ $\quad$ - $185-191$

Halisarca and its species, $\quad-\quad 192-193$

Additions and Corrections, - $\quad$ - $194-202$

The British Lithophytes, $\quad$ - $\quad$ - $\quad$ - $\quad 203$

Synopsis of the Genera, $\quad$ - $\quad$ - $\quad 205$

The British Corallines, - $\quad$ - $\quad$ - $207-215$

Opinions of Ellis of them, - $\quad$ - 208-210

Lamouroux, - - $\quad$ - 210-211

Lamarck, - - - 211-212

De Blainville and Schweigger, - 212-214

Link, - - $\quad$ - $\quad$ - 214-215

An experiment with Corallins, _ $\quad$ - $\quad 215$

The genus Corallina and its species, - 216-223

Jania and its species, - $\quad 224-227$

Halimeda and its species, . 228-230

The Nulliporidæ, character of, - $\quad 231$

Opinions of by Ellis and Pallas, - . 233-234

Lamarck, - - $\quad$ - 234

Blainville and Borlase, _ $\quad 234$

Schweigger and Link, _ $\quad 235$

Their probable origin from Corallines, - . 236-237

'The genus Nullipora and its species, - _ - 238-242

Synopsis of the Sponges, $\quad$ - $\quad$ - $\quad$ - $\quad 243-252$

Lithophytes, - - $\quad$ - $253-255$

Explanation of the Plates, - $\quad$ - $\quad 257-260$

Index, - - $\quad$ - 261-264 
THE.

\section{B R I T ISH S PONGES}

$A \times D$

\section{I T H O P H Y T E S.}

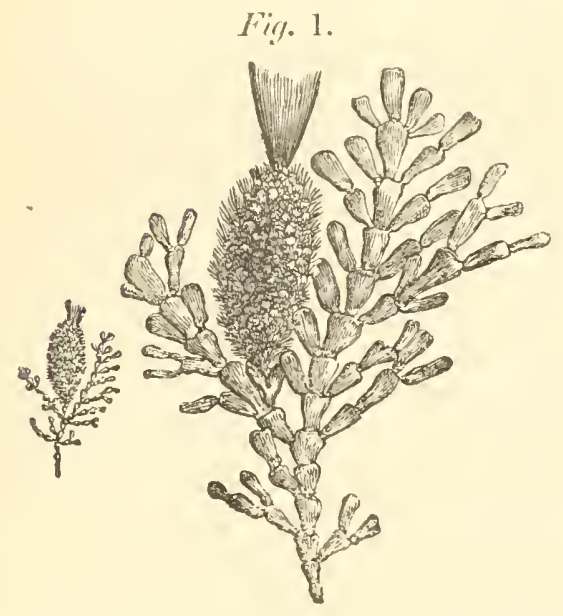

Grantia ciliata: Corallina officinalis.

“ In Spongis vitæ, fabricæ et naturæ animalis tcrmiuus esse videtur." "Interim inter ambigua zoophyta Corralinas collocavi, ne seriei deessent, si quis probet eidem inserandas esse."-Pallas. 
" Dices, - - quod temporis et studii in eam impendendi jacturam cornpenset? Respondeo, Voluptas illa et delectatio innocens et bonesta, quæ ex operum Dei contemplatione oritur."-Raius.

" - Thy desire, which tends to know The works of GoD, thereby to glorify

The great Workmaster, leads to no excess

That reaches blame, but rather merits praise

The more it seems excess;

For wonderful indeed are all His works,

Pleasant to know, and worthiest to be all

Had in remembrance always with delight."

Miltort.

"I do not like your cui bono men."

Sir H. Scott. 


\section{PAR'T I. \\ THE BRITISH SPONGES.}

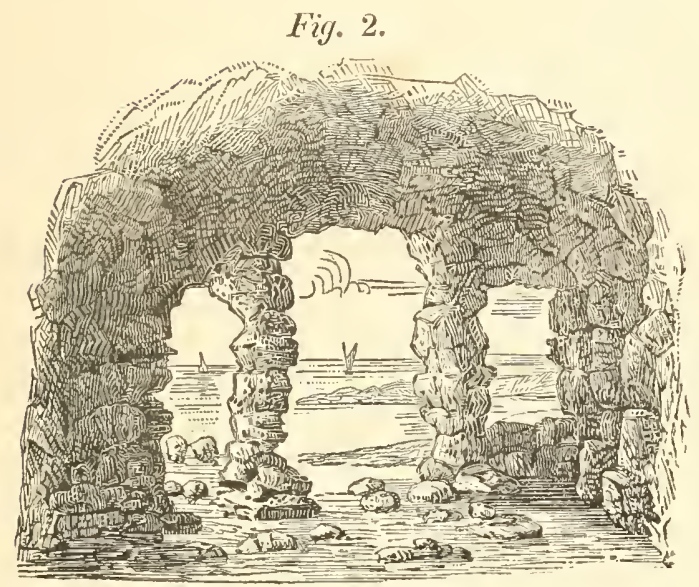

Holy Island Coves.

"I loved to walk where none had walk'd before, About the rocks that ran along the shore:

Here had I favourite stations where I stood, And heard the inurmurs of the aeean-flood."

Crabbe. 
"Quibus Spongiarum fertiles Oceani tractus lustrare contigerit bene multa invenient quæ superaddant et magnum in scientia naturali explebit hiatum, qui plenam Spongiarum historiam dabit, gnaris gratissimam eerte futuram atque utilissimis observationibus feracissimam." - Pallas.

“ Le genre des Eponges est très riche en espèces curieuses, et mérite d'être etudié."-Cuvier.

“Les Éponges sont connues de tout le monde, sont employées de toute antiquité aux usages domestiques; et cependant, ont plus besoin d'être étudiées que la plupart des genres de l'ordre où elles se trouvent.' -Bosc.

"Comprendo bene quanto la storia delle Spugne sia interessante più che quella pi altro Polipo, e quanto ancora sia imperfetta."- Cavolini. 


\section{THE BRITISH SPONGES.}

I.

Every one may be presuned to be familiar with the general appearance and structure of Sponge. It is a light elastic porous substance formed of interlaced horny fibres, producing, by their numerous inosculations, a rude sort of net-work with meshes or pores of unequal sizes and usually of a square or roundish angulated figure. Besides these pores there are some circular holes of a larger size (oscula) scattered over the surface of most sponges, and which lead into sinuous canals that permeate their interior in every direction. The oscula, canals and pores communicate freely together, for the structure of the sponge is alike throughout the mass, or at most the texture of the surface is merely a little more compact than the imner parts. The characteristic property of sponge is the facility with which it imbibes a large quantity of any fluid, more especially of water, which is retained amid the meshes until forced out again by a sufficient degree of compression, when the specimen re- 
turns elastic to its former bulk. From this peculiarity, combined with its pleasant softness, arises the value of sponge; and for the purposes to which it is applied, in domestic economy, and in surgical practice, we are not aware that any other production can be conveniently substituted.

When the sponge is recent and living its canals and pores are filled with a glairy colourless fluid like the white of an egg, which flows freely out on the remoral of the sponge from the water. The quantity of this fluid varies according to the species. In some it is copious even to nauseousness; but in the compact Halichondrix there is little of it, and in the Grantiæ it appears to be entirely wanting. It " has an unctuous feel, emits a fishy odour when burnt, leares a thin film or membrane when evaporated, and appears to the naked eye transparent, colourless, and homogeneous, like the colourless part of an egg. But, when a drop of it is examined on a plate of glass under the microscope, it appears entirely composed of very minute, transparent, spherical or ovate gramules, like monades, with some moisture. These monade-like bodies, nearly all of the same size and form, resemble the pellucid granules or vesicles, which Trembley has represented as composing the whole texture of the Hydræ, or the soft granular matter we observe in the stems of living Sertulariæ; and, indeed, most of the fleshy parts of organized bodies appear to be composed of similar pelhucirl granular or monade-like bodies in different states of aggregation." "*-The chemical properties of this fluid have not been ascertained : its sensible qualities, if we assume that the smell of the sponge flows frum it, are not altogether the same throughout the class,

- Cirant in Edin. New Fhil. Journ. ii. p. 124. 
for, as Professor Grant has remarked, "the odours of some sponges are decidedly animal, while others belong to common and well-known vegetables. The Spongia coalita, when newly taken from the water, sinells very strongly of the common mussel, and when burnt, it still resembles the same bivalve burnt; the Spongia compressa, on the other hand, smells strongly of the common mushroom ; some, as the Spongia oculata, have scarcely a perceptible odour." *

The composition of the skeleton or fibrous portion of the sponge is remarkably diversified, but in this sketch I limit myself to a notice of the variations exhibited in our typical native species. In the true sponges (Spongia) the fibres which bound the intercellular spaces are horny smooth subcylindrical threads, of unequal thickness, and, according to Ellis and Grant, tubular throughout, so that the continuity of the canal is uminterrupted even at the junctions or anastomoses of the net-work; $\uparrow$ but Dujardin and $\mathrm{Mr}$ Bowerbank have proved that this is an erroneous description of the structure, for the thread is in fact solid and imperforate. + (Fig. 3.) The fibres of other sponges (Halichondria) are formed of slender crystalline spicula composed of silex or flint in a pure state, laid in a not over-exact parallelism, and bound togetler by a substance analogous to horn or albumen; but there are many species of Halichondria in which this albuminous matter is diffused, so that the fibrous structure has become obscure, and the spicula, now predominant, lie crossed in every direction and.

- Edin. Phil. Journ. xiii. p. 96.

+ Ellis and Soland. Zooph. p. 184: Grant in Edin. Phil. Journ. xiy p. 340 .

| Microscopic Journal, i. p. 10 ; Annals Nat. Hist. vii. p 73. 
comparatively free. These sponges have been compared to the crumb of bread, and the comparison conveys a very

Fig. 3.

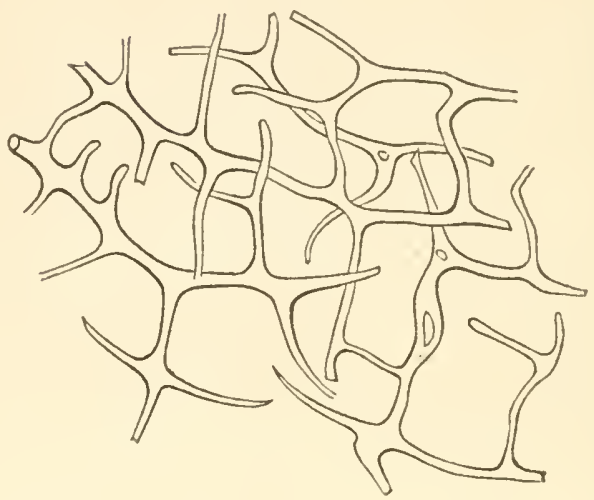

exact idea of their struture as seen with the naked eye. In a third class of sponges (Grantia) there is no net-work, their basis being a porous membrane rendered compact and firm by the profusion of spienla immersed in it, and these consist solely of carbonate of lime. The siliceous spicula form mostly needle-like spines, but there are found along with them, in the genus Tethya, some that might have been the model from which mythological painters have drawn the trident they have placed in the hands of Neptune. (Fig. 4.) The calcareous spicula are more variously shaped,-_either simple and acicular, or clavate, or formed with three or even, sometimes, with four prongs. (Fig. 5.) The two kinds, viz. the calcareous and siliceous, have not hitherto been detected coexistent in any native sponge; but the spicula of every species are rery constant to the same figure, although in point of size they vary exceedingly, nor have I heen able to diseover any 
certain order in their arrangement. They are probably hollow in the centre and closed at both ends. "When the spicula are examined through the microscope after this

Fig. 4.

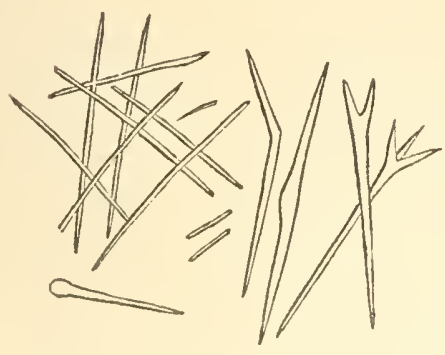

Fig. 5.

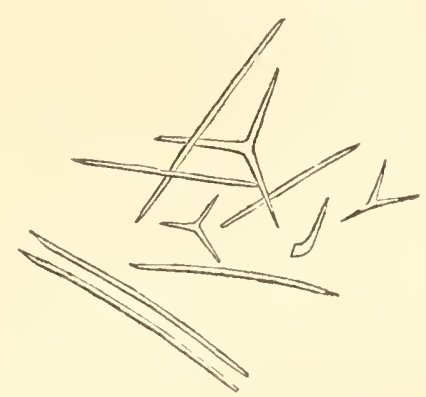

cxposure to heat, we distinctly perceive," says Dr Grant, " a shut cavity" within them, extending from the one point to the other ; and on the inflated part of each spiculum we observe a ragged opening, as if a portion had been driven out by the expansion of some contained fluid. In those spicula which had suffered little change of form by their incandescence, I have never failed to observe the same cavity within, extending from one end to the other, and a distinct open rent on their side, by which the contained matter has escaped before the usual globular distension had taken place."* The sponges containing spicula, in any degree of profusion, are inapplicable to domestic purposes.

Sponges are all aquatic prorluctions. "In their natural state they are soft and elastic, and possess lively colours; but many of the species, by drying, become quite friable, lose their fine shades of colour, and become whitc. Soon

- Edin. Phil. Journ. xiv. p. 184.-According to Mr Bowerbank, the epicula have a central cavity "lined with an animal membrane, which becomes converted iuto a thin film of carbon when the spicula are exposed to the action of the blow pipe."-Anı. Nat. Ilist. vii. p. 74. 
after death, they pass through a bluish colour to black, by putrefaction. The whole body of a sponge is specifically heavicr than sea-water; and each of its parts taken separately sinks in that element." * A rery few of a green colour inhabit our ponds and sluggish rivers; the rest are marine. Of these many of the calcareous and siliceous kinds inhabit the shores between tide-marks, preferring a site near the low ebb, where, nevertheless, they are daily alternately submerged and left exposed to the atmosphere. The figured sponges with a fibrous texture, to whatever genus they belong, and the fleshy Tethya, are the denizens of deeper water, and are never left uncovered. They grow, usually in groups, on rocks, shells, shell-fish, corallines and sea-weeds, and either have no power of selection, or the quality of the site is indifferent to them. When, however, from the locality, they are exposed to a greater than usual agitation of the sea, it is said that the structure of the sponge becomes denser and more compact than in its normal condition of developement.

In their growth some sponges assume a determinate figure, or at least one whose variations are confined within certain limits that do not render tle form nugatory as a specific character; but the greater number are very irregular and variable, their shape depending, in a great measure, on the peculiarities of their site, to which they easily accommodate themselves. Thus they will incrust a shell or a crab, a rock or sea-weed, following every protuberance and sinuosity ; and the offshoots will spring up, with a more luxuriant growth, in the deeper sheltered places, until they render the original shape of the thing they

\footnotetext{
* Edin. Fhil. Journ. xiii. p. 96.
} 
grow upon irrecognizable. Even of the more fignred species, when the branches of the same individuals, or of two individuals of the same kind, come into aceidental contact, they speedily coalesce, and the union is so natural and perfect that no difference of structure-not cren an ideal line-indicates the original place of meeting, while the altered form may occasionally perplex the nomenclator:

" Nam mista duorum

Corpora junguntur, faciesque inducitur illis

Una. Velut si quis conductâ cortice ramos

Crescendo jungi, pariterque adolescere cernat.

Sic ubi complexu coierunt membra tenaci,

Nec duo sunt, et forma duplex, nec fæmina dici,

Nec puer ut possint ; neutrumque, et utrumque videntur."•

But this intimate mion is only between individuals of the same species, for " different species of sponge do not unite together when they come into contact: they form a slight adhesion, but the line of separation is easily traced, and they can be disunited without laccration. When the Spongia tomentosa meets the Spongia papillaris, the margins of both adhere together, rise a little from the rock, and proceed directly outward, as if endeavouring to surmount each other, till their contest is arrested by the action of the waves, which would soon tear off the unsupported margins, if they proceeded outward to any considerable extent." $\uparrow$ I have scen these facts strikingly illustrated with Halichondria tomentosa and H. sanguinea, which grew intermingled in such a manner that they had formed a specimen resembling the map of a county where cvery riding was coloured or white or red, and where the hom-

- Ovid. Metam. lik. iv. ix. 1. 373-9.

$\dagger$ Edin. Phil. Journ. xir. p. 115. 
daries were too distinctly drawn to admit of any debateable neres on either side.

Sponges are ummoving and unirritable : hence they ever remain rooted to the places of their germination, and are incapable either of contracting or dilating themselves, or even of moring any fibre or portion of their mass. They possess no polypous tenantry, - their oseuli and pores are unfurnished with tentacula,-and their interior is equally vacant of the simplest viscera which are found adumbrated at least in all other animated entities. Of such unformed and insensate productions we naturally presume that the functions which distinguish them as living beings must he few and faintly imaged; and notwithstanding the attention paid of late to the subjeet, we find that considerable obscurity hangs orer their physiology.

It has been already shown that the surface of the sponge is everywhere porous, and that its interior is permeated with irregular sinuous canals which open externally by orifices much larger than the pores. The common belief had been that the sponge had the power of sucking in the circumfluent water through these larger orifices, and of throwing it out again from the same orifices, after some detention of it in the canals and meshes. The current was an intermittent one with an alternate ebb and flow:*-Of late the prevalent theory has been that the water is insensibly absorbed by the pores and enters the interior net-work, penetrating to every point and carrying with it mutriment and air : thence it is forcert into the canals, along which it runs in a continuous stream that finds its issue from the body at the larger orifices or oscula. (Fig. 6.) By this effuent stream

" "spongia-foraminibus respirat açuam."-Lin. Syst. Nat. p. 1296. 
we are told that all excremental matters are carried out,every thing to wit which has become effete, or which has been

Fig. 6.

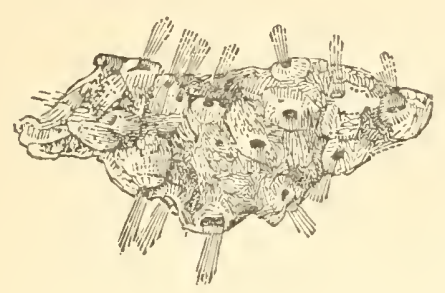

rubbed down by exposure to its force. The direction of the currents is said to be invariably the same; and a sort of al'aneous web is described as being spread within the osculid, caleulated to prevent the ingress through them of any foreign bodies floating abont, which might otherwise disturl the functions of the sponge by blocking up these conduits and rents. There are, however, many sponges which are entirely destitute of oscula, and whose surface is equally and uniformly porous; and the pores of these, we are compelled to believe, may be, at different periods, and under varying circumstances, either suctorial or vomitive. Dr Grant deseribes the influx and efflux of the water as constituting an uninterrupted stream, flowing as long as the sponge continnes to be submerged and in health; and, according to the same authority, it is ofttimes strong enongh to be distinguishable with the naked eye,-especially if any light powder is strewn over the surface of the water to guide the eye to its course and origin.

This physiology of the sponge we owe to Professor Grant. The theory is so consistent with the strueture and low organization of the object, and is deduced from such an extensive series of well-told experiments, that it made 
its way unquestioned among naturalists in general, and was admitted unhesitatingly into elementary works of the highest character; * but it should be remarked, that the authors of them added no other confirmation of it than what we may allow is due to the fact of the impression of its truth made on the minds of able and judicious men, by the many proofs of it which Dr Grant had adduced. The testimony of Dutrochet, and of Audouin and Milne-Edwards to his accuracy is more valuable, for the former of these eminent naturalists verified the existence of the circulation through the River Sponge; and the latter had seen the phenomena on which the theory rests in the sponges of the shores of France. $\uparrow$ And although I am well aware of the donbts which have been recently raised on the subject, from the experiments made on the River Sponge by Mr Joln Hogg, $\ddagger$-experiments which I shall afterwards mention in detail, - - yet I camnot share in those doubts, for even as this sheet passes through the press, I and my family have had the pleasure of observing the circulation distinctly in the Halichondria papillaris, Flem.; and it is with nnfeigned satisfaction that I find myself in a position to bear witness to the minute accuracy of $\mathrm{Dr}$ Grant's description of the phenomena accompanying it. The current issues from the oscula in a continuous stream, which is agitated like boiling water; and minute granules

- See Fleming's Brit. Auimals, p. 519. Roget's Bridgewater Treatise, i. p. 151-4. Grant's Outlines of Comp. Anatomy, p. 8. MilueEdwards in the 2d edition of Lamarck's Anim. s. Vert. ii. p. 535. Stark's Elem. of Nat. History, ii. p. 424. Mantell's Wonders of Geology, p. 458. Sharpey in Cyclop. Anat. and Physiology, i. p. 612. Gray in Synopsis of British Museum, p. 57.

+ Hist. Nat. du Litt. de la France, i. p. 76.

$\$$ Linnean Transuctions, xviii. p. 390, and p. 402. 
are seen to be carried out from the sponge in the current at short and irregular intervals. It is impossible to witness the scene without being at once satisfied that it nust flow from some cause connected with the ritality of the sponge itself; nor does it seem possible that a circulation so uniform in its course, and continuous and turbulent, can be maintained by the breathing of any insect, worm or mollusk fortuitously nestling in the sponge, and which, moreover, were in vain sought for.

By this circulation, sponges operate the usual changes of organized beings on the water around and within them, for they soon die unless this is often renewed; and they render it equally unfit for the support of other life. On what power the circulation depends is unascertained. That it cannot be ascribed to any contraction or irritability in the sponge, or in its pores and canals, is very certain; but other two explanations of it have been offered. Dr. Grant considers it to be very probable that the pores and canals are lined with minute vibratile cilia, by whose well ordered and regulated play the current is originated and maintained; but he arlmits that he had not been able to perceive the cilia after the most careful search for them, and after he had become familiar with the best modes of detecting their presence with the microscope. Dutrochet, on the contrary, considers the phenomena as coming moler his law of endosmosis and exosmosis; * and to this supposition I am well

- To those of my readers who are not familiar with Dutrochet's theory, the following illustrations of it may be necessary. "When the cacum of a chicken was half-filled with milk, tied, and then immersed in rain-water, he found that it became gradually fuller and fuller, and at length very turgid, having, in 36 hours, increased in weight from 196 to 313 grains. When a denser thid was substituted for the milk, such 
disposed to assent. It is, indeed, evident that, from the unequal densities of the mucilaginous secretion of the sponge and the circumfluent water, there must be unceasingly going on an oozing out of the one, and an entrance inwards of the other, in obedience to the law in question, which Dutrochet discovered to regulate the transmission of fluids through all organic membranes. By this singular process of reciprocal exchange we account probably enough for the exhalation of the excretions of the sponges, and for the admittance of the circumfluent water ; nor is more necessary for their sustenance and growth, since, like plants, they appear to live solely on water and its nineral ingredients. This liquid food is not received into any cavity, but permeates to all points, and is equally elaborated in every part of the system, which, in one sense, is an umconfined digestive cavity, where the various ingredients are separated, selected, and fitted for appropriation by each species agreeably to its nature. For example, it

as albumen or solution of gum, the weight and turgescence were still more increased, and their increase was more rapidly eompleted; in eight hours and a half, a eæcum partially filled, and weighing 58 grains, became extremely turgid, and weighed 130 grains. This transmission of the water by inward impulse or Endosmose, exists to a certain, but much inferior degree, when the cæeum is empty. It occurs always when the internalfluid is more dense than the external." "When, on the contrary, the cæeum was filled with rain-water, and immersed in any of the abovementioned aetive fluids, such as milk or albumen, the water passed outwards through the membrane. In like manner, a weak solution of gumarabic passed outwardly towards a stronger solution. The last-mentioned faets are examples of Exosmose or impulse outwards. - But the phenomena of Endosmose and Exosmose are always eoneurrent or reeiprocal ; that is, in each of the examples hitherto given, the external fluid passes inwards, while the internal fluid passes outwards." See an excellent review of Dutrochet's Discoveries in Physiology, in Edin. Med. and Surg. Journal, xxxi. p. 383. 
is rery common to find growing on the same rock or seaweed, a siliceous, a calcareous, and a horny sponge; they have all the same exposure, and are all recipients of the same nutriment, yet does each act upon this differently. One extracts from the fluid silica, which it causes to assume a solid crystalline form; another selects in the same manner the calcareous particles, which, obedient to the laws of life, assume figures novel to them in their mineral state; and again, another rejects both the lime and fint as injurious to its constitution.

The propagation of sponges is another disputed part of their economy. That they are not born of love is very certain, for no one, since Pliny's time, has ever imagined that there was any sexual difference in the individuals of any species. The fresh-water sponge produces abundantly, when in favourable situations, oviform bodies or capsules flled with germinal grains. On the bursting of the capsules, these are set free, and by a locomotion, probably dependant on extrinsic causes, scatter themselves abroad, and diffuse the species. (Fig. 7). The capsules are, on the con-

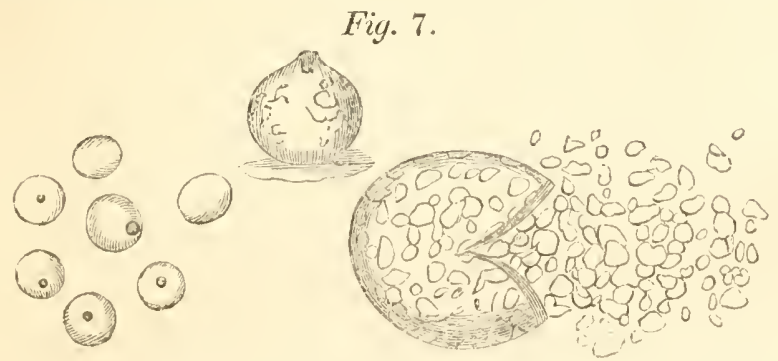

trary, unmoveable, and often germinate without bursting ; while also many specimens of the sponge never produce them, but propagate their kind by seminal granules alone, which appear to be merely detached particles of the orga- 
nic moncus that fills the intercellular spaces. I have never met with similar capsules in any marine sponge. * In the Tethya, and in one or two Halichondrix, there are occasionally found oriform bodies, lying apparently loose in the Tethya, but so firmly attached to the fibres of the Halichondriæ, that they are not easily detached : they are large enongh to be visible with the uaked eye, are of a roundish or egg shape, and are composed of a gelatinous basis, in which numerous spicula are immersed. Indeed, in structure they do not differ essentially from the parent, and seem to be young or embryo sponges developing themselves within the body, whence probably they escape when this has died and decayed. They can scarcely he considered identical with the ora which Dr. Grant discovered that a few sponges prodnced in the spring season, for he describes these as being more regularly egg-shajed, of a yellow or orange colou, and covered with vibratile cilia, excepting on the narrow end, which is naked of them. These ova in fact resemble very exactly the reproductive gemmules of the ascidian polypes; and, when mature, being de* tached and carried from the parent mass by the effluent currents and the movements of their own cilia, they float and swim abont in the sea until they have found a place suitable for their growth and developement. But in truth these eiliated ova and the oviform bodies are found in so very few species, and so seldom even in

- Ehrenberg it seems has seen them " in very many sponges of the Red Sea." Hogg in Lin. Trans. xviii. p. 40l. Mr Hogg has endeavoured to show that long before Donati had represented similar capsules in a Tethya in his Stor. Nat. dell' Adriatico, tab. viii. fig. C, $c, t$, and fig. E, $a, a$; and Muller in another sponge, evidently referable to the same genus, (Zool. Dan. tab. 157, fig. 1, 2, $a, b$.); but these bodies, which I have also seen, are not similar to the capsules of Spongilla. 
them, that they camot be considered to be the ortinary media of the propagation of sponges in general. Their very position in the scale of organized beings, - racillating between the lowest members of the two kingdoms,-forbids us to believe that sponges could be oviparous; and, consistently with this theoretical deduction, in by far the greater number which I have examined, there has been no appreciable difference in the composition or texture of the species at whatever season, or at whatever stage of its growth, the examination has been made. Thus I have been led to conchude that sponges are propagated by self-division,-by detaching at irregular intervals, and in the form of sporules, scarcely regulated by seasons, small portions of their mass or gelatine, which, carried abroad by tides and other influences, fall into favourable situations, and gradually there develope, until they assume the form and textmre of their originals. *

Sponges inhabit every sea and shore. According to Lamouroux they are very abundant and various between the tropics, but become less so in temperate latitudes, and continue to diminish in number, in variety, and in size as we trace them into European and colder seas, until they almost disappear in the vicinity of the polar circles. The branched sponges with a compact feltred tissue are more common than others in the scas of cold regions, where the species of a loose texture, which grow in large massive forms, either do not exist or are very rare. In this order of distribution sponges agree with other zoophytes, and seem

- The fibre of a dried sponge is frequently coated with "a "ruguus film, containing minute granulations " Mr Bowerbank considers these granulations to be the incipient gemmules of the sponge.-Microse. Journ. i. p. 9. I believe them to be the matured gemmules or sporules. 
to be ruled by the same influences; while they run counter, says Lamouroux, to sea-weeds which cover in profusion the bottom of the icy seals of the two poles. * I know not on what data the Professor of Caen has grounded these gencral remarks. Of the numerous species arranged under the genus Spongia by Lamarck 51 are said to grow in the Australasian seas or un the shores of New Holland, 22 in the Indian Ocean, 4 only in the Red Sca, 9 in the Mediterranean, 14 on the American coast, and 9 in the seas of Europe. $\dagger$ It is too obvious that no conclusions of the slightest value can be drawn from these imperfect lists, and the geography of the sponges must forlong remain a field of exploration and discorery, for before it will yield any fruit, either to the naturalist or geologist, the species must be all re-exanined with a eare not yet bestowed upon them, so that they may be referrerl to their proper genera, and those of every zone made to exhibit their mutual resemblances and discrepancies.

What special uses sponges perform in the economy of creation has been little enquired into. It would appear that they are not made the food of any other tribe of animals; and the shelter which they give to some shell-fish, crabs, and worms is accidental, or without any appropriated adaptation. There are a very few exeeptions. Thus Mr Hogg las diseovered a very simgular insect (Brunchiotoma spongille, Westwood,) which has not been detected in any other situation than in the eells of the fresh-water sponge ; and some marine Cirripedes or acorn-shells, - the Acastee of Leach.-nestle habitually in a sponge,- the nor-

- Polyp. Coral. Flex. p. 16.

† Anim. s. Vert. 2de edit. ii. p. 542-573.

F Lin. Trang, xviii. p. $390-1$. 
mal construction of the base of the shell being altered to suit the peculiarities of its habitation. There is in this instance a foreseen relation between two very dissimilar ereations. The habitat of Bulamus spongeosns, says Colonel Montagu, is extremely curions: "it is found enreloped or bedded in a particular species of sponge, exposing nothing but the points of the operculum."- "Amongst the reticulated fibres of this sponge the Balanus finds a secure lodgement in its infant state, and is soon enclosed by the growing fabric of the sponge animal, except a small opening, which is kept clear by the vortex occasioned by the constant motion of the feelers or tentacula of the Triton inhabiting the shell."*-But these are too trivial offices for so large and widely spread a family, and probably the power which its members possess of redueing to a solid condition the horn, the silex and lime of the waters they live in, is what constitutes their importance amongst rival entities, and gives them a certain infuence orer the phases of this ever-changing globe, - an influence which we shall certainly underrate unless there are taken into accomnt their vast numbers and universal diffusion,-their size in more genial seas, - and above all their unceasing operation on the waters, contimued from age to age withont one moment's intermission. That they were called carly into existence we know from the remains of them found in nearly the carliest of fossiliferous rocks; and the same evidence assures us that they have never been without an heritahle succession. Thus the number and rariety of their speeies in-

- Testacea Britannica, Supp. p. 3

$\dagger$ Sponges occur fossil in the tertiary, cretaceous, oolitic, perbaps in the carboniferous, in the silurian, and probably in systems even older than this. See Phillips' Treatise on Genlngy, i, p. 7.6. 
crease in the newer oolitic group; and they appear to constitute the most abundant fossils of the cretaceous or chalk formations. * "The upper part of the chalk throughout a large portion of England," says Mr De La Beche, " is characterized by the presence of numerous flints, more or less arranged in parallel lines." $\dagger$ These hard homogeneous flints, which are usually in the form of figs, pears, or of nodulons masses, are, it may be conjectured, the indurated remains of compact siliceons sponges; as the siliceous grains and spicula mixed with the chalk itself appear to come from their disintegration or dissolution.

- De la Beche's Geological Manual, pp. 271, 297, 333, and 456.

+ Geological Manual, p. :259.

Fig. 8.

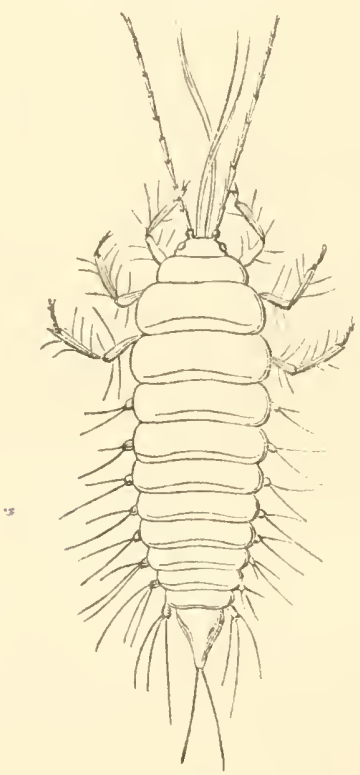

Branchiotoma srongnLl, Westu. 
11.

\section{History of Opinions and Discoveries of the Nature of SPONges.}

Spoxge has been used, for domestic purposes, from a very early period, but as an object of scientific inquiry, its history begins with Aristotle; and it appears not improbable that his attention may have been drawn to a production unlikely, from its amorphous condition and obscure properties, to have otherwise attracted notice, by the extent and importance of its fisheries in the Mediterranean and Red Sea.* "The sponge," says the Stagirite, " is a

* The name of sponge shows that it was early noticed for its peculiar

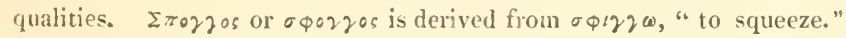

"Then with a syonge be drest

"His face all orcr, necke and hands, and all his hairie breast."

Homer. Hiad, bk. xviii. by Chayman.

In some islands of the Archipelago the inhabitants are trained from infancy to dive for sponges. "The greatest part of the spunges that are sold comes from the Hediterranean, and there is a certain Island of Asia that furnishes us with a very large quantity of spunges. This Isle is call'd Iearus or Nicarus, where the yomig men are not allow'd to mar$r y$, till they show that they can gather spunges from the bottom of the sea; and for this reason, when any one would marry his duughter, a number of young fellows are stripp'd and jump into the sea; and he that can stay longest in the water, and gather the most spunges, marries the maid." Pomet's Complete llistory of Drugs, bk. v. p. 102, 
stationary or rooted animal, and seens to have some sensation, for they report that it is torn away with difficulty unless the attempt be made without warning;" or, as he words it in another place, (Hist. 1. 5.) " if the sponge perceives a person about to pull it off, it contracts itself and is difficult to be taken away, and it does the same when there is much wind and sea, in order that it may not be uprooted; but there are some persons who doubt of this, as the inhabitants of Torone." Its generation is spontaneous in the hollows of rocks; and, like other attached things in the sea, it is nourished by the mud, of which they are found full when taken up. "And in the canals or apertures of the sponge are small crabs (pinnophylaces) which, by opening and closing a sort of araneous net-work over the apertures, do catch small fishes,-opening it for their entrance and

Lond. 1748. Somewhat to the same purpose Hasselquist writes. - "Himia is a little, and almost unknown island, directly opposite Rhodes: we saw it in the morning on our right hand. $1 t$ is worth notice, on account of the singular method the Grecks, inhabitants of the island, have to get their living. In the bottom of the sea the common spunge (Spongia offic.) is found in abundance, and more than in any other place in the Mediterranean. The iubahitants make it a trade to fish up this spunge, by which they get a living, far from contemptible, as their goods are always wanted by the Turks who use an incredible num. ber of spunges at their bathings and washings. A girl in this island is not permitted by her relations to marry, before she has brought up a certain quantity of spunges, and before she can give a proof of her agility, by taking them up from a certain depth." Voyages and Travels in the Levant, p. 175. Lonil. 1766. - The duty on sponge, in 1829 , produced L.3650, 16s. The duty is $2 \mathrm{~s}$. on all that is imported fiom foreign countries, and $6 \mathrm{~d}$. on that imported from a British possession. M'Culloch's Com. Dictionary, p. 989. “In commerce two kinds of sponges oceur :- the Turkey, which is of the finest texture, and obtain. ed from the Mediterranean, two species of which Mr Bowerbank makes out; and the West Indian, the source of which is principally the Bahama lslands, and consisto of one species only." Microse. Journ. $j$. p. 9. 
closing it when they have gone in." It nourishes also animals within itself, both worms and other similar creatures, which, when the sponge is plucked off the rock, fishes devour, as well as the roots which are left behind: but the sponge, being torn $1 p$, will grow again from the remaining part and fill out as before.

" There are three sorts of sponges,-one of loose, another of close or compact texture, and the third, which they call Actilleum, is very fine, and very thick and very strong; which they put under helmets and greaves (viz. between the armour and the skin), whereby blows are rendered less stunning; but this kind is very rare. Of the compact sponges, those which are very hard and rough are called tragi."* "The loose sponges are the largest, and the thick close ones the softest, for the Achilleans are firmer than these last. But, in general, those which grow in deep and still water are the softest; for the wind and waves harden sponges as they do other things that grow, and check their growth; on which account those in the Hellespont are rough and thick, and in general tliose which are beyond the Malean promontory, and those within it differ in being softer or harder: but the situation ought not to be too warm and sheltered, for the spongc, like other things which grow, is liable to rot; wherefore those on the shores are the finest when they are near decp water,

- "Of spunges, we find three sorts: the first thirke, excceding hard, and rough; and this is ealled Tragos : a second, not all so thicke, and somewhat softer; and that is named Manon: the third is fine and yet eompact, wherewith they make sponges to elearse and scoure withall, and this is tearmed Achilleum." Pliny, Trans. P. Holland, i. p. 262. The name Tragos, "he-goat," refers to the course shaggy appearunce of the sponge so called; Manon in Greek denotes a loose open tex ture, full of apertures. 
for then they partake of both advantages. When living and unwashed they are black to look upon. The place of attachment is neither at one point only, nor extending to the whole sponge, for there are empty passages in the space between, but a sort of skin is stretclied round the lower parts, and the attachment is at several points. Abore most of the passages are closed, but four or five are visible; wherefore some persons say that these are the passages by which the sponge receives its food.

" There is another sort which they call Aplysia, because they cannot be washed clean. This last sort has the large passages, but is otherwise quite close, and when cut through they are closer and tougher than the sponge, and on the whole like the substance of the lungs: and this sort is allowed by all to have feeling and to be long-lived. They are distinguishable in the sea from the sponges, in that the sponges are white with the mud resting upon them, but these are always black."

So far it may appear that Aristotle is fuvourable to the belief in the animality of the sponge, but when we remark the guarded manner in which he reports that opinion, and recollect that the book which contains its evidence was intended as a popular introduction to the more exact and detailed treatises, "de Partibus," "de Generatione," \&c. we must look in the latter for the conchusions to which his own observation had led him. Now in the work "on the parts of animals," sensation is plainly denied to the sponges, which, moreorer, are asserted to have altogether the character of a plant; but, perhaps, we more correctly reflect Aristotle's views when we represent the sponge as a production intermediate between the vegetable and animal 
kingdoms, "for Nature," as Aristotle saiys in more than one place, "passes continuously from things without life to animals through things which live yet are not animals, so as that they appear to differ very little one from another when viewed in connection. The sponge, both in that it lives only when attached, and when separated eannot live, is quite on the same footing as the plants; but what are called Holothuria and Pneumones and other similar productions in the sea, differ a little from sponges in that they are detached, yet they have no sensation, but live like plants detached. And there are such among land plants; some which live and grow on other plants, and some entirely umattached, as that fiom Parnassus, which some call epipetron, for this lives a long time hung up upon pegs."**

Pliny's account of sponges is cntirely borrowed from A ristotle, and he also puts them among those productions " that have a third or middle nature, and are neither living creatures nor yet plants." In a subsequent chapter, however, wherein is enumerated at length their various economical and medicinal applications, he has apparently forgotten their " middle nature," and declares that he had before proved the sponges to have life, "yea and a sensible life," " for their is found of their bloud settled within them." And as it were to strengthen this opinion he adds-." Some writers report that they have the sense of hearing, which directs them to draw in their bodies at any sound or noise made, and therewith to squize out plenty of water which they cont-

* Aristot. de Part. Animal. 1. iv. p. 95 . I ain indebted to the liev. Thomas Riddell of Trinity College, Cambridge, for this account of Aristotle's knowledge and opinions on sponges. The passages quoted are translated from Bekker's edition. Ferlin, 1829. 
tained within; neither can they easily be pulled from their rocks, and therefore must be cut away; whereby they are seen to shed a deale of bloud, or that which resembleth bloud very neer." - Pliny further informs us that some writers distinguish sponges into male and female, "for some of them they have thought to be of the male sex. to wit, those which have smaller pipes or concavities, and those growing thicker and more compact, whereby they sucke rpmore moisture; and these, our delicate and dainty people die in colours, and otherwhile give them a purple tincture. Others they count of the female sex, namely such as have bigger pipes, and the same running thronghont one continuity without interruption. Of the male kind, some be harder than others, which they call Tragos; the pipes whereof are the finest, and stand thickest together." ${ }^{\text {** }}$

It thus appears that sponges were the first of the zoophytes to have their animality asserted, - a fact sufficiently remarkable seeing that in their fixedness, their unsymmetrical shapes, their texture and defect of all defined organs, and their insensibleness, they exhibit every evidence which would naturally force us to a contrary conclusion. And these evidences, from ontward shew and appearances, soon proved their influence, for when, after the revival of letters and science, natural history began to be studied anew, sponges were uniformly classed and described as members of the regetable kingdom, being reckoned among the most imperfect productions of their class; and as they were unseminared, so, in accordance with the theories of the period, their generation was attributed to a fermentation of

"P. Holland's translation of "The Natvrall Historie of C. Plinivs cerindrs," i. p. 262-3 ; and ii. p. 423. Lond. 1634. 
the sea's scum, or its spontaneous pullulations. "'There is found," says Gerarde, "growing upon the rockes neare vnto the sea, a certaine matter wroughit together, of the fome or froth of the sea, which we call spunges." It is true that the notion of their animal nature was not allowed entirely to die away, for every successive compiler retailed the relations of Aristotle and Pliny, but no one was thence induced to remore the subjects of them to the animal kingdom. Thus Ferrante Imperato, who is said to have had suspicions of the animality of other zoophytes, unhesitatingly describes the sponges among cryptogamous vegetables, and expresses lis opinion that, in their structurc, they were nearly allied to the Fungi. His short preface to the description of the Neapolitan species contains a condensed view of what he found in Aristotle, with whom he agrees in attributing to the sponges in general a power of alternate contraction and dilatation when under the influence of some painful irritation, but he believes the contractile medium to be the mucilaginous fluid that fills up the interstices of the sponge. $\dagger$

Ray rejects what the antients have said of the life and sensation of the sponge, of its spontaneous movements or contractility, and of its food and nourishment as being partly unproved and suspicious, and partly as false, for who, he asks, can believe, on the sole argument of small shells having been found in them, that sponges can feed on shells or on fish? He would rather believe that the shell-fish had

" Herbal, emac. p. 1578.

1 Historia Naturale di Ferrante Imperato, p. 635. Venetia, 167:. _- Nieremberg, en 1635, regardait les Eponges commes des productions animales, et soutenait cette opinion, quoique contraire à celle qui etnit alors généralement reçue." Lamouroux, Ilist. C'or. Flex. p. 10. 
crept into their pores and holes for shelter, or for the purpose of feeding on thesponge. The statement of this shrinking moler the divers' hand he consider's to be equally incredible, but naturally enough explains the origin of the story from what we know of the inherent elasticity of the productions in question. He agrees with Imperato in considering them as of all marine regetables the most nearly related to the Fungi, being composed of a substance like compacted wool, perforated with tubes and holes, and covered over with a certain membranaceous mucilage. The sponges live affixed by a root to rocks, shells, and in sand; if torn away they shoot up again from their root and grow as other plants do. Their peculiar property is to be easily compressed and then again to swell out to their pristine bulk; hence the facility with which they imbibe any fluid and allow it to flow out on the application of conrenient pressure.*

Even so late as the year 1760 , when his riews had been well considered, Linnæuis arranged the "Spongia" amongst the cryptogamous alge ; $\dagger$ but undoubtedly previous to this, the position of the genus in the "Systema Naturx" had been rendered racillant by new discoveries. About the commencement of the 18th century, Marsigli, " that fair investigator of nature," asserted that he had seen a motion of contraetion and dilatation in the pores or oscula of several sponges just removed from the sea.t Marsighi, how-

- Historia Plantarum, auct. Joanne Raio, i. p. 80 ; and iii. p. 16 Lond. 1686. Syn. Stirp. Brit. i. p. 29.

† Systema Nature, edit. 10, ii. p. 1348.

$\ddagger$ "Plusieurs espèces d'Eponges lorsqu'elles sortent de la mer ont dais de certains petits trous un mouvement de systole et de diastole, qui dure jusqu'd ce que l'eau qu'elles renferment soit entièrement consunée." Hist. de l'Acar. Roy. des Sciences, 1710, p. 96. 
ever, believed the sponges to be plants; and the proof whicl others saw, in his observation, of their zooplytical character, was deemed inconclusive by $\mathrm{V}$ alisnerins, who weakened its force and bearing by comparing the alleged movements to those of the sensitive plant.* Peyssonel's discovery of the animality of zoophytes in general, followed quick on that of Marsigli; and when the truth of this was generally recognized, after the confirmation it received, about the middle of the century, from Trembley, Donati, Jussieu and Ellis, there was rather too much eagerness among zoologists to adopt the sponges also, and to restore them to the rank they held in the writings of antiquity, for the facts on which this restoration was rested were of a much less satisfactory description than those which proved the animal nature of the Hydra, the Sertularix and Alcyonia.

Donati was led, by the researches he had made into the productions of the Adriatic, to regard the sponges as an order of Plant-animals,- - a class of beings pertaining to neither kingdom of organized matter, but connecting them by embodying their essential attributes; and among which were some species ( $T$ ethya) that had even some relationship with minerals. $\dagger$ From observations made on the American coast, Peyssonel was, on the contrary, induced to belicve that sponges were fabricated by eertain worms which are frequently net with in their sinnosities and pores. This opinion was disproved by Ellis, tho shewed that Aristotle

- Ephemerid. Acad. Leopold. cent. x. p. 345.

† Della Storia Naturale Marina dell' Adratico, p. lvii. c. p. Ixiii. Venezia, 1750.

‡ "This kind of insect, which harbours in sponges, I have seen ; but sponges have no such animals to give them life, and to form them." i:llis in Lin. Corresp. i. p. 180. 
was right in considering these worms to be aliens that sought the sponge merely for eoncealment and safety; yet this has not prevented the theory from being occasionally revived, and within these few years it was favomably entertained by Sowerby. Ellis was inclined at first to think that, like other zoophytes, sponges would be found to be polypiferous, and that the polypes, or " animals of a particular class," were to be sought for in the orifices which open on the surface, or in the tubular fibre whieh, by its inosculations, forms the complicated retieulation of the whole mass. $\dagger$ But he very soon satisfied himself of the erroneousness of this notion of their strueture; and his mature opinion was that the sponge is an animal sui generis, "very torpid, growing in a variety of forms, composed either of reticulated fibres, or masses of small spines interwoven together, which are clothed with a living gelatinous flesh full of small mouths or holes on its surface, by which it sucks in and throws out the water." He says that he had observed the mouths or holes to contract and dilate themselves in one species (Sp. urens); and in another, or a variety of the same ( $S p$. cristata), he plainly observed the water to enter and pass out of these holes; or as he, in another place, expresses it, these mouths did "suck in and squirt ont the water," thus "giving evident signs of life.” $\ddagger$

Pallas adopted the views of Ellis implieitly. $\$$ Sponges, he said, were simpler and more imperfeet than any other

- British Miscellany, p. 85 and 131.

+ Brit. Corallines, p. 79.

‡ Phil. Trans. abridy. xii. p. 260: Ellis and Solander's Zoophytes, pp. 184, 186, and 187: Lin. Correspondence, i. pp. 161, 164, and 180. Zoul. Journal, i. p. 286.

\$ Elenchus \%oophytorum, [. 375-6. 
zoophyte, - the last link of the long chain of animals, from which nature stept, without visible effort or leap, to the fungous and algous tribes of the vegetable kingdom. $\mathrm{He}$ thought it probable that they imbibed their nutriment by the pores or cavities alone, in which the offices of a mouth and stomach might be perhaps combined, as they are in the pores in the roots of terrestrial plants, and in the superficial pores of the algæ or sea-weeds; * but he acknowledges that nothing certain had been ascertained of their mode of growth and propagation.

In the 12th edition of the "Systema," published in 1767 , Linnæus, following the advice of Ellis and the example of Pallas, arranged the sponges amongst animal zoophytes, but, from the position which they occupy, it appears that he did not consider them the very lowest of their race. His definition of the genus is :- "Spongra. Flores. (Foraminibus respirat aquam.) Stirps radicata, pilis contexta, flexilis, bibula." $\dagger$

From this date the animality of sponges was generally assumed, and the ideas of Ellis regarding their structure and functions were as generally admitted, but not altogether without the protest of a small minority. Spallanzani was the most celebrated of these; and, from Iamouroux and Mr Gray, $\ddagger$ we learn that he was joined in his

* "Spongiarum, quanı reliquis omnibus Zoophytis, multo simpliciorem atque imperfectiorem esse fabrican cum Ellisio sentio. Eoque magis ad vegetabilia accedunt, quam reliqua bujus ordinis genera. Cliymicis etiam principiis paulo similiores plantis deprehenduntur. Credibile est poris solis aut cavernulis nutrimentum recipere Spongias easque cavernulas oris simul et ventriculi vices genere, uti pori radicum in plantis terrenis et superficiales in Algis." Elench. Zooph. 376.

† Syst. Nat. i. p. 1296.

+. Hist. Corall. Flex. p. dl ; and Zoological Journal, i. p. 47 and 49. 
advocacy of their regetable nature by Forskäll and Targioni-Tozetti, both of them practical naturalists, and who had giren speeial attention to the sulject. Their observations went umheeded, for when a novel theory has by its lappily combining and connecting a number of hitherto isolated facts, satisfied public opinion, the oppositions to it are set aside, being reckoned among those exceptions which ouly wait on future diseovery to prove their relationship to the others and their right of reception into the general law.

In 1785 Cavolini published the result of lis researches into the nature of sponges. They were made on the Spongia officinalis, $L i n$. and on a compact fleshy species described by Imperato, both of which are found plentifully in deep water on the rocks of Gajoli in the bay of Naples. The fishermen here believed in the contractility of the sponge, but by numerous experiments, made under the most favourable circumstances, Cavolini satisfied himself that, neither in its general mass nor at the oscula, was it contractile or irritable in the slightest degree, for it showed no evidence of being so when torn up by hooks or when cut and lacerated with sharp instruments; and he lad equally strong evidence for saying that Limnæus was wrong in asserting, after Ellis, that the oscula or months were respiratory pores for sucking in and alternately expiring the cireumfluent water. Notwithstanding these decisive experiments Cavolini was yet induced to admit that a very faint degree of contractile power might reside in the sponge, reminding us at the same time that the appearanees of it were probably cansed by the pressure of the instrument used in the experiments on the surrounding tissue; and he has no doubts of the sponge's ani- 
mal nature, though he believes them to be the very simplest productions of their class.*

The experiments and opinions of Cavolini coincide exactly with those of Colonel Montagu published at a much later period, but the English naturalist had evidently no knowledge of Cavolini's excellent work. "With respect to the nature of sponges," says Montagu, "there has been considerable difference of opinion; but, in the present era of natural history, it is pretty generally allowed, that they are truly of an animal substance, extremely torpid, and for the most part, if not wholly, destitute of visible motion. IVith considerable attention to some species taken fresh from the sea, and others that I have examined in the cavities of their native rocks, still immersed in their natural element, not the smallest motion was perceptible, nor were there any appearances of internal action; for such would have produced some currents or slight agitations in the water, which must have been perceived by the assistance of glasses. Action, however, is by no means necessary to constitutc an animal; for in many instances vitality is known to exist without mobility."

"The actual distinction between animal and vegetable life is, perhaps, so small and indefinite, that the physiologist will scarcely venture to say where the one terminates and the other commences; the only material distinction between them appears to consist in their constituent parts.

"By chemical analysis, there appears to be an infallible character of specific distinction, by which they are with certainty recognised. That character', therefore, discovered in

" Memoria per servire alla storia de' Polipi marini di Filippo Cavolini, p. 266_272. Nap. 1785. 
all animal matter, has been proved by chemical decomposition to exist in sponges.* Motion, as already observed, is not essential to animality; and in their inertion, zoophytes, especially sponges, approximate so nearly to vegetables, that it is only the peculiarity of their constituent parts (which we are enabled to discover by the aid of chemical science) that separates them. It is not essential to the formation and growth of animal substance, that a lieart, brains, or even intestines, or any viscera, should exist, no more than it is, that all vegetables should possess roots."

"Whether motion has ever been discovered or not in any species of sponge, is not, I conceive, of so much importance as some naturalists would appear to consider. Those who are solicitous in their inquiries after the animals which they have supposed to construct the resicular fabric of sponges, and have expressed their surprise, that, in this age of cultivated science, no one should yet have diseovered,--must have taken a very limited view of matter possessing vitality, and have grounded their hypothesis only upon supposed analogy. Why should it be concluded that sponges are only the midi of insects or vermes; or why should not organic matter possessing vitality without action, exist? If these philosophers expect to find polypes, or vermes of any kind, to be the inhabitants of sponges, they will be deceived. The true character of Spongia is that of a living, inactive gelatinous flesh, supported by innumerable eartilaginous or corneons fibres or spicula, most commonly

- "The odour produced in the combustion of sponges, and other zoophytes, is similar to that of other animal substances, mixed with a peculiar marine orlour, well exemplified by oysters roasted in their shells; and which is very different from the effuvia of burning vegetable matter." 
ramified or reticulated, and furnished more or less with external pores or small mouths, which absorb the water, and which is conveyed by an infinity of minute channels or capillary tubes throughoit every part of the body, and is there decomposed, and the oxygen absorbed as its principal nourishment, similar to the decomposition of air in the pulmonary organs of what are called perfect animals.

"The food of sponges," Montagu continues, " must be similar to that of plants; for a sponge has no more power to digest gross bodies than a Fucus or a Conferva; and nothing can be more admirably adapted to a gaseous aliment than the construction of a sponge. The conformation of a sponge better entitles it to the appellation of ser-lungs than any other marine production, since the water absorbed by its capillary tubes becomes as greatly divided, as air respired by pulmonary organs; and thus, by such an extensive surface offered to the water, decomposition may be effected in the same way as air is decomposed in the lungs of terrestrial animals."*

The observations of Bose on the species of this family are of little value. He thinks their appearance, consisting as they do, of a tissuc of fine fibres interlaced in every direction, such as we see exhibited in the structure of some aquatic conferva, renders the error of those naturalists who have taken the sponges to be plants very excusable; but the fact which proves their animality is the odour they exhale in burning, although it had been attempted to invalidate this conclusion by saying that the smell might ra-

* An Lssay on Sponges, with Deseriptions of all the Species that have been discovered on the coast of Great Britain, by George Montagu, \&e. in the Wernerian Memoirs, ii. p. 71-75. Edin. I8I8. The paper was read to the Society on 9 th March 1812 . 
ther proceed from the incineration of the worms that had sheltered in the cells. That the oscula were the mouths of the sponge had, he thinks, been proved by Ellis; and he and Girand Chantrons had, with no better success than their predecessors, sought in vain for polypes in the fresh water species.*

Cuvier was led by the eustom of others to place the sponges at the end of the polypiferous zoophytes, $\uparrow$ but he merely glances at a tribe which he had never personally examined, and which had never engaged his attention. The remarks of Lamouroux are more diffuse, while his opinions are equally unformed. With lim the sponges constitute a separate family among the corticiferous polypidoms, or such as are composed of a rind, or exterior and enveloping crust, supported by an internal or central axis, but they have no polypes, or these are imperceptible. From all that had been written about them, it follows that the mucilaginous fluid is the most essential part of the sponge; that the polypes, if there are any, should be found in that fluid, or that it is itself the animal of this polypidom. Its form is subordinated to that of its habitation; it is perhaps an animated mass which may be divided without destruction to the vital principle, in which there is no perceptible organization, no very apparent motion, no mouth, no organs, nothing, in a word, of that structure which we observe in other animals. This hypothesis, he adds, is not new, but is less problematical than any other, and the observations wlich he har made upon the sponges of the

* Hist. Nat. des Vers, iii. p. 162-166. Paris, 1827.

† Règne Animal, iii. p. 321. 
roast of Cakvados seem to lend support to it.* The functious of the oscula are scarcely known, "but observation leads us to conclude that they answer the purpose of introducing water into the central parts of the polypidom: so that if there are any polypi internally they may be supplied with the necessary aliment." $\dagger$

Lamarck's views are stated with characteristic confidence, and are remarkable for their erroneousness. As he prided himself in assigning correctly the right of precedence to every animated being, it would be rloing his memory injustice not to mention that sponges are, in his judgment, a ligher effort of nature's creative energy than the Sertularix, the celliferous corallines, or even than the madrepores and the true coral! Between the sponges and the Alcyonia there is a demonstrable affinity, the only essential difference between them being the earthier condition of the gelatinous crust which envelopes the latter, so that on drying it consolidates into a coating of a suberose or coriaceous consistence, while in the sponge, from its greater fluidity, it either rums ont when the specimen is taken from the water, or leaves only a pellicle behind. Now as it has been proved that the Alcyonia are true polypidoms, and that the polypes are less simple than those of many other polypidoms, Jamarck conchudes that sponges must be equally the productions of prolypes, and of polypes too which must liave a structure nearly similar to that of the Aleyonians. He infers also that the common mass of

* Histoire des Polypiers coralligene- flexibles, vulgairenent noinmés Zoophytes, par J. V. F. Lamouroux, p. 13. Caen, 1816.

+ Lib. cit. p. 15; and Corallina, p. 150. Lond. 1824.

\$ "Sans doute, en citant les alcyons, je n'enteuds pas parler de ces animaux composés, à corps commun, gélatincux ot sans polypier, que 
the sponge, as well as its polypes, must be highly irritable, and hence lends a willing ear to the statements of its sensitiveness and contractility, which he even exaggerates: and we are told not to wonder that the polypes remain undiscovered, but to seek the explanation in the character of their substance, which is a very transparent, hyaline and colourless jelly filling the interstices of the sponge, while the polypes, pullulating on the surface, are most minute. And now, after this exposition, he exultingly exclaims, all the observed facts relating to sponges easily explain themselves, and fix beyond dispute our ideas on the origin and nature of these bodies. We know that the sponge is a soft, light, very porous, yellowish, greyish or whitish body, which has the property of imbibing much water that flows out again upon compression. Scattered over various species we observe holes of a considerable size (oscula), which are not the cells of the polypes, but holes of communication that furnish a common passage of issue to several polypes, and by which the water reaches them. Nevertheless certain excavations which we observe in the sponge are the result of foreign bodies round which the polypes are developed, or little hollows useful to the life of the polypes which issue there.*

The opinions of Professor Schweigger of Königsberg, who has paid especial attention to the family of sponges,

l'on a confondus avec les alcyons, d'après une apparence exterieure; mais je parle des vrais alcyons, c'est-à-dire, de ceux qui ont un polypier, lequel, dans sa structure, offre des fibres cornées, empâtées d'une pulpe qui se conserve et s'affermit dans son desséchement. Or ce sont ces corps qui ont avec les éponges des rapports que l'on ne saurait contester." -Anim. s. Vert. ii. p. 348.

- Histoire Naturelle des Animaux sans Vertèbres, ii. p. 346-351. Paris, 1816. 
stand in strong contrast with those of Lamarck. He lias, indeed, no doubts of their animality, and assigns them a position in his system which gives them similar affinities amongst zoophytes, but his own experience, as well as the testimony of others, had convineed him that they were truly apolypous. " I have often," says he, "watehed sponges at different times of the day and year, in the shade and in the light, but never saw an appearance from which the existence of polypes in them could be even conjectured." In regard of their alleged irritability, lie appears to have entertained doubts so far as the common mass of the sponge is concerned, but he tells us that he had frequently seen the oscula of species of his genus Manon * contract themselves, so slowly and stealthily, however, that the fact was rendered evident only by measuring their diameters after an interval. "I never actually saw this motion, but within 5 or 10 minutes separate oscula were noticed to be wider or narrower at one time than they were before." The sponges which he had an opportunity of examining were divisible into three principal kinds,-one which is covered on the minutely porous surface with a continuous layer of gelatine through which the water filters into the interior as it may be presumed to do in the agastric infusoria and gelatinous medusx, - another distinguished by having distinct and ample oscula for the admission of the nutrient water,-and the third are the tubular sponges into whose carity the water enters by the wide hole which opens at their extremity. "The walls let in 110 water, but it flows unhindered through the open end, and

"Maxos-“ Stirps lacunosa, e fibris reticulatis. Gelatina superficiei ostiolis distinctis amplis. Polypi nulli." Handb. p. 422. 
fills the hollow of the sponge." All these sponges are composed of a fibrous skeleton and a jelly which penetrates and lines the whole, although it varies much in quantity in different species; and he makes the important remark, that at certain seasons it contains a more liquid portion full of granules. The gelatinous portion, he says, forms the least part of the sponge, and is copiously filled, at least in larrest, when his observations were mostly made, with a liquid matter which flows out on the slighitest pressure. This liquid is sometimes of a different colour from the jelly, and consists in a great measure of granules. These are found principally in the interior between the fibres, for they are scarcely to be observed in the slimy exterior coating, nor was there any order in their distribution. Olivi and Vis have considered this fluid to be different in kind from the thicker slime, but it appears to Schweigger to differ merely in its degree of consistency. It is probably analogous to the fluid granular matter contained in the tubular stems of the polypiferous Sertulariadr, and as the gemmules of these hydraform animals are merely developed and detached portions of this matter, it would seem to follow that the granulous fluid of the sponge is really its seed.*

Mr J. E. Gray, in 1824, argued earnestly against the animality of sponges. $\dagger$ The contradictory statements and authority of preceding writers, which he collected together, were pretty equally balanced in relation to the presence or absence of any animal faculty; and the argument ednced

- Beobachtungen auf Nauruhistorischen Reisen von August Friedrich Schweigger. Berlin, 1819: and his Handbuch der Naturgeschichte. Leipsig, 1820.___ I need scarcely call attention to the sameness of Schweigger's views of the propagation of sponges with those given in Chap. I. of this volume.

+ Zoological Journal, i. p. 46-52. 
from their chemical composition is fallacious, "for most of the marine plants emit when burnt an odour analogous to that of animal substances, which appears to originate in the simplicity of their structure and their habitation." He was led to the conviction of sponges being plants by olserving that the fresh-water sort contained myriads of minute green granules, which, when shaken from the common mass. were observed to grow and develope entirely after the manner of vegetables. The opinion had been entertained by Mr Gray for some years, for sponges are introduced into the "Natural Arrangement of British Plants," published in 1821, by Samuel Frederick Gray, and in the compilation of which the celebrated zoologist is believed to have assisted.

Mr Gray's attention wats also particularly drawn to the " internal structure" of sponges, but his generalizations were hasty and erroneous, for he evidently means us to infer from his statement that the fibres of all sponges are composed of agghtinated spicula; and of the nature and rariety of these he appears to have been ignorant. He says- "On examining the sponges which have come under our obscrvation. (not a small number of specics), they all appear to be essentially formed after the same mamner. that is to say, of Iongitudimully placed transparent fusiform spicula, which vary considerably like the species, in size and in the closeness of their connection, for in those speries that appear to be fibrous, the fibres are composed of spicula united together by a cartilaginous sulstance; and the Spongia tomentosa, which is the one saicl to br formod of bundles of spicula by Ellis, if it he carefully examined. by breaking it from the centre of the base to the rireum- 
ference, the spicula will be found to be disposed and slightly united into fibres, leaving cells; but when it is broke transversely it appears to be formed irregularly : and in the Tethya the spicula are very large, and are felted together, with their points towards the surface, into a hollow subglobular form, so that it is in fact originally a tubercle, formed of one series of spicula, which from the intervention of new spicula between the old ones, increases in diameter, and thus produces the central space. The spicula of species which I examined had the base slightly cut into two or three radiating processes."

Within a few months of their publication the opinions of Mr Gray were controverted by Mr Thomas Bell, who fully agreed that the fluriatile production that formed the subject of Mr Gray's experiment was a true regetable, while he denied that the conclusion could be extended to those species of sponges which are on all sides allowed to belong to the group. " No longer ago than last autumn," says Mr Bell, " being on the Dorsetshire coast, I cxamined the structure of recent marine sponge with care, and certainly discovered no traces of the granules described by Mr Gray, (and which, in fact, ahready formed one of the generic characters of Spongilla, according to Lamarek.) One very important fact however I have ascertained, and that is the power of contraction and dilatation in the tubes of which this substance is composed. I placed a piece of sponge, immediately after it was taken from the sea, in a glass of sea-water; a little dust had settled upon the surface, and upon looking attentively at the water, the regular alternate motion and rest of the dust upon the surface, immediately orer the mouths of the tubes, most distinctly 
and satisfactorily shewed that the water was alternately stcked in and expelled from them. This observation was likewise made at the same time by several of my friends to whom I pointed it out. Whether the contractile power belongs to the spongy substance which forms the basis of the tubes, or to the gelatinous crust with which it is covered, I could not of course ascertain : probably lowever, to the latter.

"Altlough perhaps we should not place too much dependence upon chemical analysis in questions of this sort, yet $I$ think it is a fair analogical argument in favour of the animal nature of sponges, that their chemical composition is wholly on that side of the question."*

In $1825 \mathrm{Mr}$ Gray forsook his first opinion, and became a convert to the animality of sponges, which, with Lamarck, he now acknowledged to be " true corals, nearly allied to Antipathes and Gorgoniæ." This conversion was occasioned by the discovery that the spicula consisted wholly of pure silica,- the quantity appearing, as might be expected, to be in proportion to the density of the fibres of the sponge. Now he learned from Ellis's description of the Gorgonia Briareus that spicula undoubtedly similar composed its axis or bone-facts which proved " a considerable affinity to exist between the sponges (both the marine and fluviatile) and the Gorgonia, which latter are known to be the habitation and production of individuals belonging to the animal kingdom." $\dagger$

"Zoological Journal for June 1824, vol. i. p. 203. _ See also Kirby's Bridgewater Treatise, i. p. 164.

$\dagger$ Amnals of Philosophy: New Serjes : ix. p. 432.-Mr Gray is now of opinion that the animal nature of sponges is not "distinctly made out." Sy'u. Brit. Mus. p. 57. 
The history of sponges was in this state of uncertainty when Dr R. E. Grant began those researches which shed a new and clear light on their functions.* He first satisfied limself that the sponge is not the production of any polypes, but, as Ellis had shown, an animal sui generis, destitute of any sensible motion in its natural condition, and which cannot be made to evince the slightest degree of contractility, under the strongest irritations, either in its body as a whole, or in any part of it, or even in the orifices. The sponge is a porous mass permeated with eanals which open on the surface by certain orifices hitherto named the oscula, and the surface is besides covered over with small pores or meshes. The inner surface of the canals is " lined throughout their whole winding and anastomosing course, with a smooth, soft, glistening membrane," so firmly connected "with the axis or skeleton of the animal, that it could not possibly contract so as to empty the whole of the internal canals, without a general contraction of the entire sponge." And although there is no contraction anywhere, yet the circumfiuent water is seen to be absorbed by the small pores and enter the body, whence it is again driven, in an even continuous current, through the canals and oscula, or, as they should be called, the fecal orifics, for they give exit to the respired water, which flows out mixed also with opalke feculent gramules. Having put a small branch of the Spongia coalita, with some sea-water, into a watch-glass, under the microseope, Dr Grant says,- " on moving the watchglass, so as to bring one of the apertures on the side of

" "Observations and Experiments on the Structure and Functions of the Sponge, by Robert Edmond Crant, M. D. \&c." in the 13th and 1 th vols, of the Edin. Phil. Jommal. 
the sponge fully into view, I beheld, for the first time, the splendid spectacle of this living fountain vomiting forth, from a circular cavity, an impetuous torrent of liquid matter, and hurling along, in rapid succession, opake masses, which it strewed everywhere around. The beauty and novelty of such a scene in the animal kingdom, long arrested my attention, but, after twenty-five minutes of constant observation, I was obliged to withdraw my eye from fatigne, without having scen the torrent for one instant change its direction, or diminish, in the slightest degree, the rapidity of its course. I contimued to watch the same orifice, at short intervals, for five hours, sometimes observing it for a quarter of an hour at a time, but still the stream rolled on with a constant and equal velocity. About the end of this time, however, I observed the current become perceptibly languid, the opake flocculi of feculent matter, which were thrown out with so much impetuosity at the beginning, were now propelled to a shorter distance from the orifice, and fell to the bottom of the fuid within the sphere of vision; and, in one hour more, the current had entirely ceased."*

From numerons experiments on many species, Dr Grant infers that all sponges in a living state exhibit this sort of circulation,-_imbibing the untainted water by the pores, $\uparrow$ and propelling it in regular currents through the wide canals and fecal orifices. $\neq$ The health and mutrition of the

- Jameson's Edin. Phil. Journ. xiii. p. 102.

† Lib. cit. xiv. p. 117 : also Ontlines of Comp. Anat. p. 310-312.

$\ddagger$ In some sponges there are no obvious orifices (oscula) distinct from the pores, but " as eurrents of water pass through the body of every living sponge, from the surface towards the interior, the same currents are continually flowing from the interior to the surface by different pasages; 
sponge depends upon its flow inwards, while the outward current carries off the excrementitious matter, as seems proved by the fact that particles of this description always pollute the outflowing water, howerer clear and pure it may have been sucked in; and the ova are likewise carried out of the body by the same means. * It was no doubt the observation of these currents, imperfectly noted, which misled Marsigli, Ellis and Bell, into the belief of a motion of systole and diastole in the orifices of the sponge, and an alternate flux and efflux of the water through them; and Montagu failed to detect the phenomena from employing magnifiers of too small a power, or from being unaware of the mode of examination by which they can be made visible to the naked eye. " "The Spongia panicea," says Dr Grant, "presents the strongest current which I have yet seen, and has the greatest thickness of body of any spreading sponge which I have met with on the rocks of this part of the Fritl of Forth. Two entire round portions of this sponge were placed together in a glass of sea-water, with their orifices opposite to each other, at the distance of two inches; they appeared to the naked eye like two living batteries, and soon covered each other with feculent matter. I placed one of then in a shallow vessel, and just covered its surface and highest orifice with water. On strewing some powdered chalk on the surface of the water the currents were visible at a great distance, and on placing some small

and it is of little importance in the economy of this animal, whether the apertures by which the currents have their exit, be large and conspicuous, or minute and less easily observable; every species of this genus must necessarily possess such orifices, great or small, for the discharge of its rurrents, its exerements, and its ova." Vol. supra cit. p. 334.

* Lib. cit. p. 105-6. 
pieces of cork or of dry paper over the apertures, I could perceive them moving, by the force of the currents, at the distance of ten feet from the table on which the specimen rested. A portion of soft bread pressed between the fingers into a globular form, with a diameter larger than that of the orifice, and placed over it, was not moved away in a mass by the stream, but was gradually worn down by the current beating on its sides, and thus propelled to a distance in small flakes. A portion of umburnt black-coal, with twice the diameter of the orifice, was instantly rolled off the mouth of this living fountain, in whatever position I attempted to make it rest upon it. A globule of mercury, of equal diameter with the orifice, let fall upon it through a glass tube was not removed or shaken, aud completely stopped the current. I now pierced, with a ncedle a thin superficial canal, in the vicinity of the closed orifice, and established a new current, which continued, even after removing the obstruction from the original orifice.

" A globule of mereury, of any smallness, placed over the orifice of a living sponge, is too heavy to be affected by the small column of water which impels against its smooth round surface, flowing at the rate with which it issues from that orifice, and is useful in enabling us to stop up the currents of certain orifices, in order to direct the stream witl greater force through a particular aperture, which we wish to examine through the microscope. By adopting this plan with a healthy Spongia panicea, which has generally very few and large orifices on the surface, we can distinctly perceive, with the naked eye, that the current never enters by the same apertures through which it issues, and we might thus measure the whole strength of 
the forces employed to produce the eurrents in any particular specimen." *-The power by which the currents are set and kept in motion, and their circuit regulated, has not been ascertained. Dr Grant could discover vibratile cilia neither around the orifices nor on the walls of the canals and porcs, such as he discovered to originate similar currents in the polypiferous zoophytes; but the analogousness of the phenomena in the two orders of living beings, almost forces a conjecture that they result from, and depend on, the same cause. $\dagger$

To Dr Grant naturalists are also indebted for the discovery of the various composition of the skeleton or framework of the sponges. Donati had long previously described and delineated certain crystalline spicula of which some Adriatic species almost entirely consist ; $\ddagger$ and Ellis had shown their arrangement in a native sponge, $\$$ and was fully aware of their more gencral prevalence and importance ; $\|$ but little precise was known in relation to them. of

- Edin. Phil. Journ. xiii. p. 104-5. - Dr Grant saw the currents, with the naked eye, also in Sp. cristata and compressa. Ibid. p. 103.

† Brewster's Edin. Encyclop. xviii. p. 844. Edin. New Phil. Journ. ii. p. 126-7. See also Sharpey in Cyclop. Anat. and Phys. i. p. 612.

$\ddagger$ Nat. Mar. dell' Adriatico. tab. 8 and 9. Venezia, 1750.

§ Eng. Corall. p. 81, pl. 16, fig. D 1.

If " Some (sponges) being composed wholly of interwoven reticulated fibres when others are composed of little masses of strait fibres of different sizes, from the most minute spicula to strong elastic shining spines like small needles of one-third of an inch long; besides these, there is an intermediate sort between the reticulated and the finer fasciculated kinds, which seem to partake of both sorts." Soland. Zooph. p. 182.

I So little that even Hatchett, after an analysis of many species, as. serts that he found them all similar in their composition. "They consist of gelatine, which they gradually give out to water, and a thin brittle membranous substance, which possesses the properties of congulable albunen." Thomson's System of Chemistry, v. p. 564. Edin 1807. 
Dr Grant, on the contrary, ascertained that certain species of sponges are entirely formed of an umpatterned network of corneous fibres, which he asserted were tubular throughout; that, in others, innumerous sharp spicula of pure silex, and of a crystalline appearance, are mixed up with the horny material; while in a third class the spicula are composed of carbonate of lime alone. These spicula of silex and lime he nerer found to coexist in the same sponge; and their figmre is so varions in the different species, that they become valuable aids in enabling us to distinguish them. *

The propagation of the sponges was another object of inquiry. "When we cut," says Dr. Grant, "a thin piece off the surface of a living sponge, and look down through one of its pores with the reflecting microscope, we perceive, immediately beneath the projecting spicula which defend the pore, a very delicate net-work of gelatimous threats thrown over the entrance of the tube. This picee of structure is so fine, as to be perfectly invisible to the naked eye : it consists of five or six threads, which pass in from the sides of the tube to be connected with a central mesh, so that there are six or seven meshes thus formed; and while this soft apparatus is heantifully defended by the protecting spicula of the pore, it serves still farther to guard the interior of the animal from the smallest particles of sand, or the minutest risible mimaleules. Along the whole interior of the pores and tubes, there is a thin gelatinous matter enveloping every fibre, and filling all the interstices between the fasciculi. This gelatinous matter is transparent and colourless. and so little consistent, that it

* Edin. Phil. Iomm. xiv. p. 84-5 ; and 1. :3:39. 
runs lown like the white of an egg when the sponge is first torn from the roek, and suspended between the fingers; the mieroseope detects no trace of organization in it; by filling up the inequalities of the sides of the tubes, it smoothens these passages for the small streams. Every part of the gelatinons matter is covered with minute granular bodies, which are distinetly seen in every speeies of sponge by the weakest magnifier of the microseope. These granular bodies are represented in the plates of Donati, of a spherical form, adhering to the quadriradial fibres of what he has named the Alcyonium primum Dioseoridis. They are quite invisible to the naked eye; they escape along with the gelatinous matter, and compose the greater part of it; they are comnected with each other by the gelatinous matter, and probably through the same medium have some connection with the spicula along which they are placed. No part in the organization of the sponge is more constant and obvious than these gramular transparent bodies, lining the interior of every eanal from the pores to the feeal orifices. Their form is not quite spherical, but somewhat lengthened or ovoidal, and they are always attached by one extremity to the gelatinous matter, while their opposite end is seen to project free into the car vity of the canals. Through the greatest magnifier of the microscope, no difference can be detected in their forms in different species of sponge; they all appear to be enlarged and rounded at their free projecting extremity; and when watehed with attention, we distinctly pereeive that they possess some power of spontaneous motion, both when in conneetion with the sides of the eanals, and when lying isolated at the bottom of the water. The ova of the 
sponge are quite visible to the naked eye, and are seen disseminated through the whole texture of the animal in the winter season. They are bodies of a yellow colour, somewhat translucent, pear-sliaped, tapering more or less at their narrow end in different species; their whole outer surface is covered with delicate projecting ciliæ; and when viewed through the microscope, in comnection witl the parent, we see that the rapid vibration of these cilixe produces a distinct current in the water immediately around them, flowing always from their rounded free end towards their tapering fixed extremity, thus assisting the small granular bodies in producing the currents of the sponge, during the period of their attachnent to the body. They separate from the canals, and are propelled through the fecal orifices early in spring. None of these ova are seen in the sponge in summer, though we can detect no difference in the velocity of the currents at that period. For some time after they are propelled from the interior of the sponge, they swim about by means of the cilixe on their surface, and exhibit all those extraordinary phenomena of spontaneous motion which Cavolini, nearly half a century ago, discovered in the ova of the Gorgonia and Madrepore.* They at length fix themselves, like the ova alluded to, on a spot favourable for their growth; they lose entirely their original form, and become a flat transparent cireular film, through which horny fibres shoot; they soon spread, and assume a form somewhat similar to that of the parent." $\dagger$

* Except that of being unable to change their shape, as the Doctor afterwards discovered. Edin. Phil. Journ. xiv. 1) 119 ; and Edin. New Phil. Journ. i. p. 154.

+ Edin. Phil. Jomrn. xiii. 1. 381-33; and Erlin. New l'hil. Jumr. ii. p. 128-134.

The minute description which Do Grant bas giren of the structure of 
The real character and relations of the fresli-water sponges were likewise first made known to us by Dr Grant, in a memoir read before the Wernerian Natural History Society on February 11 th 1826. * Great doubts hung over them, as will appear from the opinions held by those who had most carefully examined the subject. Thus Montagu refused them a place in lis essay, for it appeared to him " that this substance is in fact the nidus of some aquatic insect, which may possibly congregate to deposit their eggs ; and that the fibres, or threads that decussate each other, are attached to the ova for their security in mass, as we perceive in those of some spiders and other land insects." $\nmid$-Lamarck says that it load not been determined whether these Spongillæ were animal productions. The fact might be presumed from their appearance and from the gelatinous grains they contain ; but no observation made in France had confirmed a suggestion of Lichtenstein that these grains were the gemmules of the Cristatellæ. Assuming them to be animals, Lamarck believes them to be much nearer affined to the Cristatella than to the marine sponges, and therefore places them wide asunder

the oscula and of the ova, I must take the liberty of reminding the reader, is taken from the examination of the oscula and ora of one or two species only. It will be found that in general the oscula are merely simple or eompound outlets, without any protective net over the orifice or in the funnel; and, indeed, it ean rarely be seen excepting in newly formed oscules, before the fibres of the sponge have been broken away by the efluent current.-The ora $I$ have found only in Halichondria panicea of Fleming, but as the specimen had been preserved in spirits, I cannot rouch for their being eiliated, which, bowever, I do not doubt. The aceuracy of Dr Grant's description of them is, however, questioned by Mr Owen. See "The Lancet," No. 871, p. 22.5.

* Ediu. New Thil. Tourn, i. p, 178.

+ Werr. Men. ii. p. 77. 
in lis system.*_-In his first work Lamouroux erred less, for he acknowledged the nigh relationship between the marine and the fresh-water sponges, which, indeed, he says are chiefly distinguished by their residence. The latter " resembles the marine Spongia by the gelatinous mucus which surrounds the mass and fibres, and which disappears on desiccation; by the very fetid smell it yields when burning or decomposing, and also by the quantity of lime extracted from its ashes, which even sometimes exceeds half the weight of the dried polypidom." $\dagger$ Subsequently, however, Lamouroux became almost convineed that the fresh-water sponges were plants. The smell, the colour, the action of the air, of heat, of humidity and light, the total absence of the gelatinous fugacious crust of sponges, represented only by an unctuous substance like that which corers certain Charæ, and the existence of opake seeds at certain seasons of the year, whose nature is yet unknown, -all these characters were remote from marine sponges, and seemed to associate the fresh-water ones with the algæ. $\neq$ -The truth is, to borrow the remark of $\mathrm{Mr}$ Bell, the old adage, "quot homines, tot sententix," was scarcely ever more applicable than to the opinions entertained of the fresh-water spongoid bodies: they are like Polonius's cloud,-a canel, a whale, or what you please. $\$$ The renark was made not many months before the publication

- Anim. S. Vert. ii. p. 99. - See also Bosc's Hist. Nat. des Vers, iii. p. 166.

$\dagger$ Corallina, p. 147-8.

$\ddagger$ Exposition Methodique des genres de l'ordre des Polypiers, avec leur description et celle des principales espèces, figırées daus 84 planches; les 63 premières appartenant à l'histoire maturelle des Zoophytes d'vllis et Solander. I'ar J. Lamouroux, D. E. S. 1. 28. P'inis, 1821, 4 to.

$\$$ Zonlogical tournal, i. 1. 202. 
of Dr Grant's memoir, when the pleasure of toying with conjectural indulgenees was so far destroyed for ever. In it he demonstrated that there was the closest resemblance between the fluviatile and marine siliceous sponges,-a similarity in strueture associated with similar phenomena. The fibrous net-work,-the siliceous spicula,-the gelatinous flud with its granular bodies,-the pores of admission to the circumfluent water, and the orifices for its expulsion,-its unintermitting eurrent, unsoiled previous to its circuit through the porous mass and loaded with feculent matter on its issue, - and the general mode of growth, whether in the state of an ovum or in the adult state,--were ascertained to be essentially alike in both. But, adds Dr Grant, " although in every respect a sponge, it (Spongilla) has a more imperfect structure than any of the marine species, which is observable in the sameness and feeble attachment of the spicula, in the great size and defenceless state of the pores and fecal orifices, in the general looseness of its surface and internal texture, in the softness of its gelatinous matter, in the want of ciliæ and spicula in its ova,indeed in every individual character."

In consequence of his discoveries, Dr Grant, at a subscquent period, separated the sponges from other zoophytes, and formed with them a distinct order under the title of "Poriphera." It is considered inferior to the Polypes in the system, but superior to the polygastric or infusory animaleules. $†$

* " On the structure and nature of the Spongilla friabilis," in Edin. Phil. Journ. xiv. p. 270_284.

$\dagger$ Outlines of Comp. Anatomy, p. 5. There is an excellent summary of Grant's discoreries by Milne-Edwards in Lam. Auim. s. Vert. alc edit. ii. P. 53.5. 
MM. Audouin and Milne-Edwards, after an attentive study of the sponges indigenous to the shores of France, confirm the exactness of Dr Grant's statements relative to these singular productions, * which certainly possess an animal life- "vivent d' une vie tout animal,"- -but to which the anatomist may be tempted to refuse animality, since le cannot distinguish in them any organ by which it is characterized. Fixed to rocks at great depths they found some remarkable bodies, belonging to this tribe of beings, whose surface was entirely covered with a thick siliceous crust. Their texture is composed of spicula of crystallized silex, varying in form according to the species, and of an organie substance which appears to be no other than a confused mass of globules of extreme littleness. The form of the elements of the crust varies also;-sometimes these are spicula, at other times ovoid granules of siliceous matter. In most of the species there are two kinds of openings in the crust in communication with the interior canals,- the lesser which give entrance to the water around them,and others, considerably larger, by which that water eseapes. These productions, allied at once to organic and unorganized matter,_- "qui tiennent à la fois de la niture organique et inerte,"-appear to belong to the Geodix, and to constitute a genus allied to the sponge.

In reference to the non-irritability of the sponges, properly so called, Audouin and Milne-Edwards agree with Dr. Grant; but they found indications of irritability in the 'Tethya,-whose structure approaches that of the semispongoid, semi-siliceous bodies just mentioned. When the Tethya is placed in a vessel of sca-water, and left, for 
a time, in perfect quietness, we distinctly see, they tell us, all its apertures agape, and the currents which traverse them. But if we irritate the animal, or remove it an instant from the water, the eurrents relax or are stopped, and the oscula eontract, by slow and imperceptible degrees, until they are almost completely closed.*

Grant and Audouin and Milne-Edwards always speak of the sponge as an animal, without any misgivings of its correctness, while the contrary was so evident to Link, the celebrated Professor of Botany in Berlin, that, even with a knowledge of the English naturalist's investigations, he proposed to remove the entire family of sponges to the Algæ. (1831.) For ten or twelve years previously he had annually found seeds, or very distinct sporangia, $\dagger$ in the Spongilla. They are as large as millet-seed, are very visible to the naked eye, and are found in minnte hollows formed by the net-work of their support : their number is very great, but in each hollow there is just a single sporangium fitted exactly to it. Hence we conclude that these bodies cannot be parasites. They are globular, nnarked sometimes with a dimple resembling a cicatrix. Their colour is yellowish-green, and the firmess of their envelope is considerable. When we break these receptacles of the seeds, and view them through a high magnifier, we perceive that the seeds are plunged in a soft mass laid on a gelatinous membrane, which is reticulated or forms a filleted work: when dried the mass assumes the appearance of a crust.

* Recherches pour servir à l'histoire naturelle du Littoral de la France, i. p. 76-8. Paris, 1832.

$\dagger$ The Sporangium is defined by Professor Lindley to be the externat case of the secds of Lycoperdon and its allies. Introduction to Botany, p. 209. 
pierced with holes, and with the microscope we see that the meshes enclose some slender, transparent, colourless tubes, divided by septa at measured distances. Sometimes we can sce these tubes or sacs project like little points on the membraue enveloping them; often it is a little filament which is enveloped; sometimes there are sereral of them, and the structure in general is not very regular.

The structure of the Spongia officinalis, and many others newly taken from the sea, is rery similar; and although spornles have not been detected in these species, yet their structural analogousness to the Spongilla, and the absence of polypes, ought to induce us to arrange them with the Algre. Ehrenberg has told M. Link that he had found sporules in sereral sponges of the Red Sea. As for the circulation through them described by Dr Grant, Link is disposed to compare it to the morements of the liquid between the articulations of the Chara, and which, therefore, is no proof of the animality of the sponge. The feculent matter mixed with the effluent current is only something membranous, and merely accidental. True Dr Grant had observed moveable ora in the Spongia panicea, but this sponge whicl, says Link, is unknown to me, is not a native of the English shores, where we find only the $\mathrm{Al}$ cyonium paniceum. And even if ova endowed with inherent powers of motion were found in sponges, that fact would not prove their animal nature, for several observers have remarked rery sensible movements in seeds, especially in those of the Confelva. Link believes that the absence of polypes, the existence of sporangia in Spongilla, the analogy between this one's strueture and the true sponges, are sufficient reasons for separating the "Spongoidés" from 
the zoophytes, and for referring them to the Algæ. It is true that the structure of sponges raries much from that of other algæ, but the structure of the latter presents already in its class such remarkable modifications that it does not surprise us to meet one more among them. Grant has observed in sponges spicula of pure silex corresponding very well to the slender fibrous points that we see in the Spongilla, and that have also equal solidity and tenuity. *

The sponges have also engaged the attention of Dujardin, a micrographer of great reputation and experience, but who seems to have had few opportunities of examining any other than the fresh-water species. He is right, I think, in asserting that the skeleton of the sponge is, under every modification, a product of secretion, and not of crystallization, as the language of Audouin and Milne-Edrards seems to imply. He recognizes the three modifications of that skeleton described by Grant, but he asserts, if I do not misinterpret his meaning, that the calcareous and siliceous spicula may co-exist in the same sponge: and he controverts the position that the fibres of the horny sponges are tubular, for, on the contrary, they are full and imperforate. The spicula are formed by the successive deposition of layers, and are mostly solid also, though in sereral there is the appearance of a longitudinal canal in the centre, and in others small cavities are visible. Those of most common occurrence are smooth and fusiform, sometimes a little arched, one-fifth of a millimetre in length, and from

" Annales des Sciences Nat. n. s. Part. Bot. ii. p. 328-30. From his last remark, Link would seem to be ignorant of the siliceous nature of the spicula of Spongilla. His Alcyonium paniceum is also evidently. a sponge, identical with our Halichondra panicea. 
one-fiftieth to one-cightieth in breadth : other's are nodose either in the middle or at the extremity ; others present sudden bends or lateral branches; and there is a very small kind of spicula which is remarkable from the muncrous spinules with which the surface is roughened.

Dujardin has examined with great minuteness the nature of the gelatinous matter that fills more or less the interstices of the sponge. By tearing up a speeimen in water this glutinous substance is set free and diffused in globules. These, when examined through a good mieroscope, are seen to change their forms gradually, so that they present themselves to the beholder under twenty different phases if he will allow a few minutes interval between the drawings of his designs. The globules move also across the stage of the mieroseope by emitting various lobes and expansions, with whose emission their loeomotion appears to be connected; and sometimes they are moved by the agitation of some very long filaments of extreme fineness and tenuity, proceeding from their sides or extremities. (Fig. 9.)

Fig. 9.

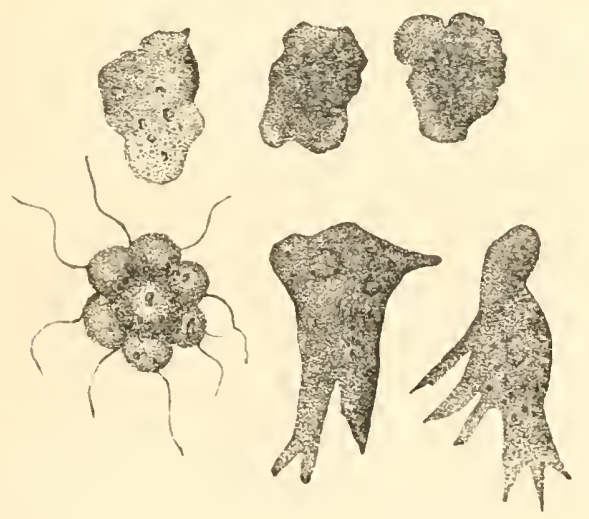


These expansions and filaments are dereloped and disappear in irregular successions, regulated in some degree by the temperature, for a high temperature acts as a stimulus upon them, while cold considerably retards the raried changes. When the globules unite into a small parcel or mass the poirer of locomotion in it ceases, but the edges continue to exhibit the same changes in their outline. In these masses we discorer some coloured granules, green in spring, and grey or rellowish at a later season. which Dujardin does not beliere to be orules or seminal, but rather of foreign and accidental origin, similar to those which tinge the animalcules of coloured infusions.

From the character of their gelatinous granules and masses Dujardin entertains no doubt of the animality of sponges, for he had previously discorered that the Amibes, and some microscopic multilocular shells, did emit a like glutinous fluid endored with precisely the same properties.*

The experiments of Dutrochet, Gerrais. and Mr. John Hogg haring been confined to the fresh-water sponge ( Spongilla), I shall defer giring the results of them until that genus comes under our special consideration. It may suffice to state in this place that these naturalists hare been led to the conchusion that the Spongilla belongs of right to the regetable kingdom. When Mr Hogg began the study of zoophytes, he participated in the then prevalent opinion of the animality of sponges in general, and deeming the organic mucus to be the most essential part in their structure, he instituted for them a distinct order in their class, which he termed Gelotinifera. on purpose to express this 
view of the animal or live jelly.* Sulsequent researches into the nature of the fresh-water sponge having convinced him of his errol so far as it was concerned, he began to imagine " that it might possibly be quite a different substance from the sea-sponges; and if so, these latter might be yet esteemed of a true animal nature. However," he continues, "still more recent and minute comparisons of many of these, as preserved in several collections, with the Spongilla, have compelled me to abandon that idea; for I cannot find any more solid ground for it, than for holding that one genus of the Fungi, as Herulius, belongs to a perfectly distinct dirision of nature, from another genus of the same order, for instance Ayuricus: and as all who should behold them would immediately and unhesitatingly acknowledge both the one and the other to be a true mushroom or Fungus; so we are equally obliged to admit that the Spongia and Spongilla are in fact both real sponges: indeed there scarcely is even so much as a generic difference between them; and in this, with the earlier naturalists Dr Fleming coincides, for be places both kinds in one and the same gemus, Halichondria."

"Both the fresh-water and the sea sponges are furnished "with a skeleton of fibres interlacing, crossing, and anastomosing with themselves; generally also strengthened with those singularly crystallized particles termed spicula; with a parenchymatous soft portion or jelly; with a fine and transparent enveloping membrane; with mmerons minute pores; and frequently with larger orifices or oscules, which are more sparingly and irregularly dispersed over their surfaces; with passages or canals communicating throngh

- Natural History of Atackton-on-Tees, p. 38. Stockton, 1827. 
the pores and oseules one with another, along which the water finds a ready course or circulation, and affords nutriment to all the inner parts of the masses; with locomotive sporules; and in some species with fixed sporidia." * Mr Hogg then proceeds to prove, by the testimony of several naturalists, the sameness of these sporidia in marine and fluviatile sponges; and he combats the argument for their animality, drawn from their chemical analysis, by showing that there exists in them no one principle which is not also to be found in certain regetable substances, while the discorery of iodine in the sea sponges determines that they more nearly resemble the Fuci. $\dagger$ He sums up the eridence of their want of animal life in this sentence: — They have no tentacles, no cilia, no mouth, no œsophagus, no stomach or gastric sac, no gizzard, no alimentary canal, no intestine, no anus, no ovaria, no ova, no muscles or muscular fibres, no nerves or ganglia, no irritability or powers of contraction and dilatation, no palpitation, and no sensation whatsoerer. Surely, then, we cannot any longer esteem these natural substances to be individual animals, or even groups of animals, in which not one organ, or

- Lin. Trans. xriii. p. 400-1. Losd. 1840.

$\dagger$ Dr Andrew Fyfe, who first discovered iodine to be a constituent of sponge, asks, "Nlay not the fact, that sponge contains iodine, be an argument in favour of the opinion of Linnæus, that this substance properly belongs to the regetable world, class Cryptogamia, from the plants of which iodine is obtained." But he adds, " it appears that the iodine con tained in sponge, is in a different state of combination from what it is in the other substances, as in the former it is not soluble in water, while it is so in the latter." Edin. Phil. Journ. i. p. 257-8. Edin. 1819; and xiii. p. 199. The argument, rendered suspicious by this circumstance, is now valueless, for iodine has been detected in cod-liver oil. Edin. Med. and Surg. Journ. liv. p. 251 ; Brit. and For. Med. Rev. x. p. 558. 
a single function or property peculiar to an aninul can be discovered."*

On similar grounds I harl previously been induced to exclude the sponges from amongst zoophytes, $\uparrow$ but it must be allowed that the alleged facts or arguments have made no impression on those zoologists who are most versed in the study of these productions. Thus Grant, Schweigger, Blainville, Milne-Edwards, Flening, Bowerbank, and Mr Edward Forbes, continue to consider them as members of the animal kingdom, although they all admit the absence of those organs and qualities that usually characterize an animal entity. This class of organized beings, says Blainville, which a great number of characters prove to be animal, is remarkable for that its species are always in more or less considerable masses having no determinate figure, and particularly for containing no distinct animaleules or polypes. Animality becoming less and less distinct as we trace down the series of creations, and in consequence also the animal form, we can recognise, neither in the structure nor in the internal organization of these lowest productions, any thing which recalls the semblance of the animals that precede them. It would seem as if now nothing remained but the common part or polypirlom, and that the polypes hare disappeared. $\$-M r$ E. Forbes, in his lectures delivered cluring the past winter in Edinburgl, tal:ght the doctrine that sponges are animals in which the life is compound, with no individual concentration, but with a tendency to such a concentration, representing the animal na-

- Lin. Trans xviii. 404-5.

† Mag. Zool. and Bot. i. p. 2:29. Hist. Brit. Zooph. p. 29 .

+ Manuel d'Actiuologie, p. 528 . 
ture imperfectly, and presenting the first appearance of that nature in the presence of (unlined) excavations in their interior for digestive purposes. They are passive, acritous and unique,-that is to say, not divisible into groups of the same value with the groups to which any of the other typical divisions of the amimal kingdom can be divided.*

There must be something in the structure of the sponge to give rise to these ingenious views, which are undoubtedly at variance with the usual definition of an animal ; and appear indeed to have been formed to obviate the objections that have hence been made to the admission of the sponges into that kinglom. What is there outwarlly more universally characteristic of animality than a defined and limited figure repeating itself, with minute exactness, through successive generations? But the amorphous developement of sponges is so remarkable that it has given the family a name (Amorphozoce), and finds no parallels excepting among the lowest tribes of vegetables. And than : irritability there is no other inherent puality of a structure that affords mequirocal eviclence of the existence of animal life in it; and yet here there is no symptom of such a quality.

But it is affimned that the numerous analogies of structure and composition which may be traced between sponges and other well known genera of zoophytes prove their mutual affunity, and the relationship to be indeed so close that the sepalration of them into distinct orders can be of no advantage to

* I an reminded by this view of the sponge, of Linnæus' definition of a vegetable:- "Vegetabile est vita composita, absque motu voluntario." Syst. Reg. Veg. p. 3

+ Sponges do not possess one of the nine essential characters of ani. mal life given by Lamarek. Anim. is. Vert i. p. 96. 2.]e edit. 
science.* The zoophytes here alluded to constitute a family of which the Alcyonium or Lobularia is the type; and while I think that the resemblance between it and the sponges has been exaggerated, I must admit that there is an agreement, sufficiently remarkable, in their composition. The fact is that from chemistry the zoologist still borrows the best support to lis elaim upon the sponges. The peculiar odour exhaled by them on being burned satisfied Hooke, the celebrated anthor of the "Micrographia," $\nmid$ Ellis and Montagn; and being familiarly known only as the effuvium of animal incinerations, it contimues to convince most of us that, if not animals, the mass whence it proceeds must be of an animal nature. "The analyses which have been made of sponges," says MMr. Merat and De Lens, " by several chemists, Geoffroy, Tromsdorff, IV clther, Hornemann, Fee, \&xc. confirm their animal nature, as they furnish, by distillation, abundant ammoniacal products, which formerly known as volatile oil and volatile salt of sponge, were put to the same uses as the analogous products of other animal matters. According to Mr Hatchett they consist essentially of gelatine and of a membranous tissue presenting the characters of coagulated albumen. According to Hornemann they contain osmazome, mucus and fixed oil. Dr Fyfe of Edinburgh and subsequently M. Gualtier de Claubry have ascertained the presence of iodine in the state of an alkaline iodide, and M. Jouas more recently the existence of bromine. Besides these they contain about half their weight of earbonate and phosphate of lime, chloride of sodiums, silica, alumini, magnesia and traces of sulphur."+

- Fleming's Phil. of Zoology, ii. p. 612-13.

† Micrographia, p. 137.

$\$$ Dict. Unis. de Natičre Medicale, r. vi. p. 512. 
Sinee, however, there are some Fungi and Algax, more especially among the Oscillatorix, which, in the proeess of decomposition, give out the same odour; and since it is admitted that chemistry furnishes no absolute test to enable us to detect the veiled members of either kingdom of or-ganized matter, the question of the rank and position of the sponges remains undeeided. And although it has its importanee, for in the framing of a natural system, the introduction of a spurious member, or the absence of an analogue, may mar and perplex the whole, yet the question will eontinue, and must be one of words merely, unless the disputants shall agree on a definition by which the line drawn between the two kingdomsean be made more real and tangible than it is in nature. If the possession of an internal digestive sac, or indeed of any limited organ for any function, - if the power of extracting nutriment from organized matter only,--if the eapability of motion, or if the presence of nerres or of irritability, be considered essential to animal life, then the sponges are not so endowed: but they will be considered to be at least animated in the opinion of those who believe that a basis similar to hom in texture and composition, intermixed with a fluid resembling gelatine, inclicates some other than a regetating life, which, in none of its acknowledged productions, has ever so combined the materials of its existenee. There is, however, nothing to forbid us believing, with the earlier naturalists, that the sponges may belong to neither kingdom; - nay the very discussion leads to the conjecture that they do actually constitute a midlle race, in whose features we can sometimes trace a predominance now of the animal and now of the regetable nature. Few on examining the 
green Spongilla would hesitate to prononnce it a regetable, a conclusion which the exacter observation of the naturalist seems to have proved to be correct; and when we pass on from it to an examination of the calcareous and siliceous marine genera, the impression is not so much weakened but that we can still say, with Professor Owen, "that if a line could be drawn between the animal and regetable kingdoms, the sponges should be placed upon the vegetable side of that line."* We shall possibly, however, arrive at an opposite conclusion if, proceeding in our enquiry, we follow the siliceous species insensibly gliding, on the one hand, into the fibro-corncous Sponge filled with its mucilaginous fishy slime, and on the other into the fleshy Tethya in whose oscula the first signs of an obscure irritability show themselves. Sponges therefore appear to be true zoophytes; and it imparts additional interest to their study to consider them, as they probably are, the first matrix and cradle of organic life, and exlibiting before us the lowest organizations compatible with its existence. 
III.

\section{The Discoverens of the Britisil Species.}

Is the "Herball" of Gerarde (1633) there is a rude figure of a British sponge scarcely sufficient to identify the species in view. It is apparently copied from L'Ores, ${ }^{*}$ who had found it on the coast of Portland Island among the seawrack. "Of this kind," says Ray, "Mr Newton also showed me specimens found by himself on the British shores.' Ray has referred it to the Spongia ramosa, but under this name the father of English Botany has clearly confounded, as he himself suspected, $\uparrow$ two or three species, viz. the Halichondria oculata, H. pelmate and stuposa. The $I I$. panicca is also recorded in the "Synopsis," on the authority

- "Matthias de l' Obel, Insulanus ad summum senium in Anglia fere vixit, Daniam etiam adiit." "Ad summam ratem usque bonus senex in plantis laboravit, et opus herbarium paravit, cui destinabat plantas a se ipso et ab uxore in itineribus per Angliam lectas. Sed labori immortuus est anno 1616." Haller. Bib. Bot. i. pp. 351, 353.

+ "Variat hæc species, et nunc ramulis est oblongis et teretibus, de qua Lobelius et Ger. Em. p. 577, quæ insula Sheppy pone Sheerness subinde observatur: vel summitatibus planis latisve, caulibus vero vel ramis augustioribus observatur : vel summitatibus est acuminatis, caulibus autem latiusculis, crebris secundum longitudinem ramulis acutis, cornuum instar enascentibus, quæ spongiæ ramosæ alterius Anglicæ nomine a Parkinsono p. 1304, exhibetur, qua varietates specie forte distingui merentur." Syn. i. p. 29. 
of Llord, * by whom it was gathered near the village of Borth in Cardiganshire, and by Ray himself near Sheerness. Ray has also mentioned the two species or varieties of the fresh-water sponge as having been found in the rivel Yare near Norwich by Newton; $\dagger$ and by Mr Bobart + in the "Thames by Swythens Wyars near Oxford;" and the same had been noticed growing in the Cam, between Cambridge and Chesterton, by Morton, - the historian of the Natural History of Northamptonshire. Dillenius, in his edition of the "Synopsis," has not added to the list of sponges, for lis "Spongia informis durior" appears to be identical with the Halichondria panicea already mertioned.\$ Eulis has described only two species in his Euglish Corallines; but in the "Zoophytes," edited by Solander, seven are very clearly defined. These are are 1. Sp. oculata, 2. cristata, 3. stuposa, 4. urens, 5. palmata, 6. botryoides, and 7. coronata:-all of which, with the important exceptions of 6 and 7 , had been previously ascertained to be natives, for the oculata is synonymous with the ramosa of Ray, and cristata and urens are merely varieties or states of his crumb-of-bread sponge. Turton, in his translation of the "System of Nature, 1806," enumerates eleven British species without, at the same time, having made one single real addition, for his Spongia tomentosa and panicea are but

* See Hist. Brit. Zoopl. p. 113, note †.

$\dagger$ Ibid. p. 119, note $\uparrow$.

$\ddagger$ Jacob Bobart, the son of a botanist of the same name, and his suecessor as Superintendant of the Oxford Botanieal Garden. He died in December 1719. See Pulteney's Sketches, i. p. 312; and Rirhardson's Correspondence, 1).9-11.

§ The "Spongia parva sordidior ex ostrearum conchis" of Plukenet; and the Pseudo-Spongia coralloides of Doody, (Syn. p. 29 and 30), I hare not been able to identify. 
one species, his lichotoma the same as oculata, and the number is completel by the introduction of the lacustris and fluriatilis, which Ellis appears purposely to have excluded, probably from entertaining doubts of their true nature.-Two good species were soon afterwards figured by Sowensy* in his British Miscellany, viz. Sp. pulchella and Sp. cancellata, but the Sp. compacta of the same excellent naturalist is but a state of the sponge like crumb-of-bread of Ray. About the same time Professor Jameson discovered some interesting species in the north of Scotland, anong which were new to Britain the $S p$. ventilabrum and infundibuliformis of Linnæus, the Sp. Zetlandica, hitherto uncharacterized, the Sp. compressa of Fabricius, and the Tethya cydonivem and lyncurizm, which, in accordance with the arrangements of the period, were referred to the genus Aleyonium.

It thus appears that at this date (December 1809) 15 different sponges were ascertained to be indigenous to Britain. But in 1812 the catalogue was greatly extended by the researches of Colonel Geonge Montagu who, in his essay on Sponges, has described 39 native species, exclusive of the fresh-water sort, and with an accuracy which no previous naturalist had deemed necessary. The following is a list of them arranged under their "families" as proposed by himself:

* Mr James Sowerby, eminent as a naturalist and artist, and by whose lahours the taste for botany in this country was greatly enlarged, died on October 25,1822 , after a long and severe illness. "His patient and indefatigable labours in several branches of natural history are well known to the scientific world; and he contributed in varions ways to the advancement of natural knowledge." Annals of I'hilosophy, n. s. iv. p. 397. 
1. "Branched; those which are properly branched, simple or compound."
1. Spongia oculata $\dagger$
2. - stuposa Ý
3. _- palmata
4. —ualita $\uparrow$

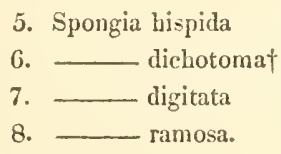

2. "Digitated; those which are divided into lobes or leaves, on their sides or on the summit."
9. Spongia conus
12. Spongia aurea
10.
13. rigida.
3. — rigida.
11. lobata perlevis

3. "Tubular; such as shoot into tubular processes, whether simple or compound."
14. Spongia coronata†
15. botryoidest
19. Spongia penicillus
16. __ papillaris
20. —_ lievigata
17.
21. - ananas
18.
22 . complicata. foliacea

4. "Compact; such as are destitute of any divisions, and are of a compact form, but of indefinite shape, whether of an open or a solid texture."

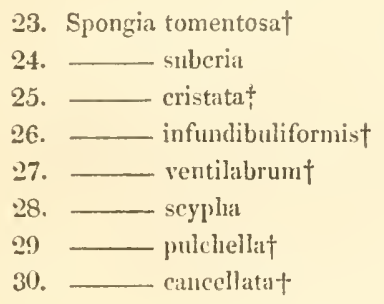

23. Spongia tomentosa $\dagger$

24.
31. Spongia limbata

32. _ fruticosa

33. _ fragilis

34. - parasitica

35. _ava

36. plumosa

87. - coriacea 
5. " Orbicular; such as are globose, with internal, radiating, asbestine spicula."

38. Spongia verrucosa $\dagger$

39. Spongia pilosa.*

Dr Grant, in the course of his researches, detected three species on the Scottish shores not included in this copions list: viz. Sp. sangumea, cinerea, and seriata.

The attention of the Rev. Dr Fleming seems to have been early directed to this family of organized beings. Montagn has acknowledged the assistance derived from him, and three of the species, riz. Sp. complicata, scypha, and pilosa, are introduced into his Essay upon Fleming's sole authority. Availing himself of the discoveries and suggestions of Dr Grant, Dr Fleming made a happy improvement in the classification of sponges, which had been previously separated into genera on characters of trivial importance and confessed instability, such, for example, as their shapes or degrees of porosity. "The axis," says Dr Grant, "differs so entirely in its nature in different sponges, that the living properties observed in one species, onght with very great caution to be extended to any other, and naturalists may probably take advantage of this difference in classifying or subdividing this numerous and obsenre tribe." $\uparrow$ This was written in 1826 ; and in $1828 \mathrm{Dr}$. Fleming carried the hint into execution. 'To such as have their axis or skeleton composed of horny tubular fibres only he restricted the name of Spongia ; he gave the name of Grantia to those whose skeleton consists of calcareous spicula; and that of Halichon-

- The species to which the character $\dagger$ is aflixed had been previously ascertained to be indigenous.

$\dagger$ Edin. Phil. Journ. xiv. ץ. 339. 
dria to such as have siliceous spicula as the basis of their structure; separating, however, from these the Tethya because of the peculiar arrangement of their spicula, and the hemispherical form of their bodies. The number of species described under each genus is as follows :

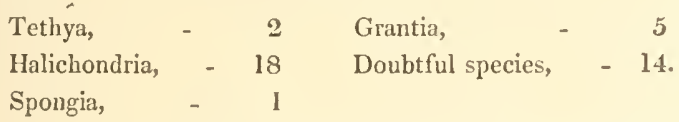

I am enabled through the liberality of my friends and fellow-students, to make some additions to this list; but notwithstanding its extent, the British shores cannot be deemed favourable to the production of sponges, for the indigenous species in general show that their waters are ungenial to the race by the rarity of the normal species, and by the dwarfed size and compact structure of the others. Of the genus Spongia we have at most but two inconsiderable representatives, about a fourth part of them are calcareous; but the great majority are secerners of silex, which they, like skilful artificers, fashion into erystalline needles and interweave with the parenchyma of their bodies.

Fig. 10.

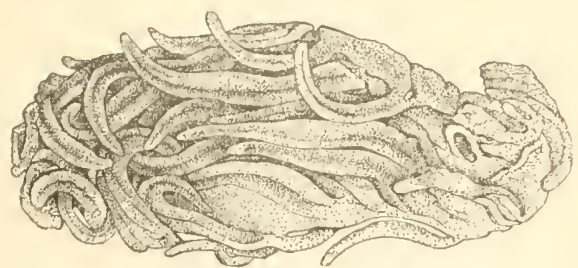

Hatichondria penichldus. 



\section{BRITISH SPONGES :}

\section{THEIR SPECIES.}

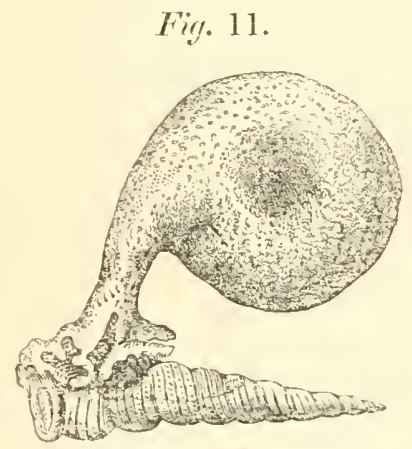

Alcyonius ficus, Exper.

"It is frequent, even with some who pretend to be naturalists, to vilify the fundamental parts of natural bistory-who view the particular species and bodies in nature; their systematic arrangement; their correct denomination; and the description of their parts and properties; as a study too minute, frivolous, and beneath their notice; whose large views are only directed to what they call the volume of nature, and the great lines in natural history. But I know of no great lines iu matural history that are not composed of small ones : nor lave I ever had occasion to arinire any man's knowledge concerning a great line, that was ignorant of its component parts."-Rev. I)r Walker. 


\section{CLASS}

AMORPIOZOA, Blainv. Man. 527.

Sposgin, Lin. Syst. Nat. 1296: Les É́ponges, Cuv. Reg. Anim. iii. 321 : Sposgites, Latreille, Fam. Nat. 547 : Alcyonideze et Spongidiz, Gray, Brit. Pl. i. 352, 354: Srongrade, Flem. Brit. Anim. 518: Spongiaines, M. Edwards in Lam. Anim. s. Vert. ii. 534, 2de edit: Zoophyta poricera, Grant, Outl. Comp. Anat. 5 ; and Cyclop. Anat. and Phys. i. 108; Roget, Bridgew. Treat. i. 147: Ceratopirta spongiosa, Schweigger, Handb. der Naturg. 421 .

\section{Cimaracter.}

Organized bodies growing in a varicty of forms, permanently rooted, ummoving and unirritable, fleshy, fibro-reticular, or irregularly cellular, clastic and bibulous, composed of a fibro-corneous axis or skelcton, often interwoven with siliceous or calcareous spicula, and containing an organic gelatine in the interstices and interior canals : reproduction by gelatinous granules gencrated in the interior, but in no special organ.-All are aquatic, and, with few exceptions, marinc. 


\section{SYNOPSIS OF THE GENERA.}

\section{Sponges are}

Fibro-reticular, the fibres liomy 4. Sronara.

Spongious with siliceous spicula

Globose, compact, fleshy 1. TeтneA.

Polymorphous, cellular and homologous
Marine, coloured
2. Halichondra.
Lacustrine, green
3. Spongilla.

Spongious with calcarcousspicula 5. Grantra.

Spongious with imberded inor-
ganic gravel
6. Duseideia.

Gelatinous without spicula or fibres 7. HaLisarea.

"Cum tamen intellectus noster absque divisione et subdivisione entia numerosissima confundat, confusisque speciebus qualibet nolitia vaga et chaotica existat: descriptio rerum methodica maxime necessau redlitur."-O. F. Muller. 
"If I fall into error with respect to Synonymes, those who have studied the subject will readily excuse it, from their knowledge of the difficulty of avoiding it. If I fail in my endeavours to define all the British species of Spongia, I am sure of obtaining two desirable objects; - that of the pleasure and information the study and researches have afforded me; and also that of allowing the scientific to participate with me in the benefit of these researches, which some friends have urged me to publish."-Colonel Montagu.

"Quant aux espèces, surtout celles qui ont perdu leur couleur, il est peut-être encore plus difficile de les distinguer et de les faire distinguer aux autres, les figures mêmes, quelque bomnes qu'elles soient, ne pouvant plus servir à recomaitre les espèces, mais seulement les individıs, qui présentent un nombre immense de variétés."-Blainville. 


\section{BRITISH SPONGES。}

\section{TETHEA, Lamarck.}

Tethia or Tethya, Laм. Anim. s. Verl. ii. 384: Gray, Br. Pl. i. 361 : Fuem. Brit. Anim. 519 : Schw. Beobacht. vii. and Handb. 422.-Les Thétbyes, Cuv. Req. Anim. iii. 321.-Tethium, Bla1nv. Man. 544.

Character. Sponge tuberous, suborbicular, solid and compact, invested with a distinct rind or skin, the interior sarcoid, loaded with siliceous crystalline spicula collected into bundles and radiating from a more compact nucleus to the circumference. Marine.

A distinct and well-characterized genus, but not so happily named, for although the Tetie of Donati is one of its species, the Tethea of Pliny appears to have been a mollusk resembling the oyster. "Lateris dolores leniunt hippocampi tosti sumti, tetheaque similis ostreo in cibo sumta." Hist. Nat. lib. xxxii, cap. 30. Moreover, Bohatsch had given the name Tethyum to the singular naked mollusk which Linnæus registered in the Systema under the name of Tethis; while in the elassifieation of the Tunicata by Savigny, the Tethyee is a family of that group of animals. 
In the native species of Tethea there are neither pores nor oscula; and Mr Edward Forbes informs me that in the living T. Cranimm he did not observe any currents of water passing into or from the body. Audonin and Milne-Edwards, however, have seen these currents. When a Tethea, they tell us, is placed in a basin filled with sea-water, and left for a considerable time perfectly still, we then see distinctly all its oscula wide agape, and we perceive also the currents which pass through them. But if now the animal is irritated, or withdrawn for an instant from the water, the currents slaken or are altogether arrested; and the oscula, contracting slowly and insensibly, become at last almost close.-Hist. Nat. du Litt. de la France, i. p. 78.

The propagation of the Tethea is by means of sporules or gemmules generated within the sareoid matter. The latter resemble the parent sponge in miniature, but they have no distinct rind nor nucleus, being composed of simple spicula woren together by the albuminons matter. I can conceive no way of escape for these from the body except by its dissolution, which, we may also conjecture, with eonsiderable probableness, is an annual production. The naturalist who believes that sponges have an affinity with the Fungi will see in these particulars a correspondency which may strengthen his belief. The Tethea, he may say, is the Sea's copy of the earth-born Scleroderma; and he may remind us that, like the sporules of sponges, the sporules of Fungi are equally locomotive. The Chaos fungorum of Limmus is thus deseribed: "Habitat, uti semen Lycoperdi, Agarici, Boleti, Mucoris reliquorumque Fungorum, in sua matre, usque dum dispergatur et in aqua exclusum vivit et moritur, demum figitur et in fungos excrescit, observante illustr. Oth. Munchhausen Lib. Bar.__Zoophytorum metamorphosis e Vegetabili in Animale; Fungorum itaque contrario ex Animali in Vegetabile."-Syst. p. 1:326. 
1. T. Cranium, surface regular and closely villous.

Plate 1. Fig. 1-8.

Alcyonium Cranium, Mull. Zool. Dan. prod. 255. Zool. Dan. tab. lxxxv. (The description only, for the figure, in my copy, represents an Ophiura.) Turt. Gmel. iv. 654. Lamour. Cor. Flex. 347. Corall. 24.8.

Alcyonium globosum fibrosum flavum sctosum, Mull. Zool. Dan. tab. clvii. fig. 1, 2.

Alcyonium Lyncurium, Esper, Alcyon. tab. xix. fig. 1. Jameson in Werı. Mem. i. 563.

Spongia pilosa, Montagu in Wern. Mem. ii. 119, pl. 13, fig. 1, 2.

Tethya Cranium, Lam. Anim. s. Vert. ii. 386: and ii. 592, 2de edit. Flem. Brit. Anim. 519. Blaine, Actinol. 514. Stark, Elem. ii. 423.

Tethya pilosa, Gray, Brit. P]. i. 362. Gram in Edin. New Phil. Journ. i, 196.

Hab. Island of Fulah, Jameson. Adheres to stones in deep water, Zetland, where it is termed Sea-Apple, Fleming.

Sponge from one to two or three inches in diameter, tuberous, subglobular, flattened on its base, the surface even but rough or muricate, and hirsute from the projection of the spicula, of a uniform yellowish-white colour when preserved in spirits. A section discovers in the centre a round solid nucleus of a glistening white colour, composed of bundles of siliceous spicula laid in close parallelism. Bundles of spicula shoot from it towards the circumference, passing through a sort of fungous parenchyma of a pale yellowish colour, which connects them together and fills all the space between the nucleus and the skin. The same spicula do not traverse the whole space, but new ones originate in it, where bundles can be seen to terminate, and others to begin. The spicula nearest the surface penetrate the skin and shoot beyond it, always in bundles, which issue, as it were, from the papillæ, and impart to the sponge its muricated and villous appearance. The skin is about a line in thickness, somewhat cartilaginous, uniform throughout, and of the same white colour as the nucleus. The spicula are asbestine, long, 
slender, straight, and pointed at both ends, but, from their brittleness, the points, especially of the protruding ones, are often broken off abruptly. Those of the nucleus and parenchyma are, in general, more than twice as stout as the cuticular ones, and always simple and rigid; but many of the latter are hairlike, very slender, and three-pronged at their projecting extremity, some with only two prongs, but these are probably defective from injury. Professor Grant says that there are two kinds of spicula, - a long straight fusiform sort, and the other shorter, curved, of equal thickness throughout, and rather obtusely pointed at both ends. The latter are about one-fourth the length of the straight ones, and are found only in the rind, where they abound.

There is no appearance of polypes nor of any figured organ in the structure of this sponge, nor is the interior traversed by any canals, but there are a few irregular or scattered holes in the parenchyma, which, however, have no passage at the surface. Immersed in this parenchyma we likewise find a number of oviform bodies, large enough to be visible to the naked eye, and of an opake white colour. They are globose or ovate, slightly uneven, and somewhat spiny, from the protruding ends of spicula. When compressed between plates of glass they are found to consist of a parenchyma traversed in every direction by slender spicula, and apparently homogeneous in their composition. They are evidently the germs of future sponges, but it is difficult to conceive by what means, or by what passages, they escape fiom the parent, unless we suppose that by its death and dissolution, it gives liberty and life to a numerous offspring. -When fresh the sponge "exhales an offensive ammoniacal odour," which specimens preserved in spirits retain._-Muller had seen a specimen which was five inches in diameter and had a resemblance to the human skull. He tells us that when living the species is of a fine yellow colour, but sometimes whit- 
ish, especially when young; and that it is covered with a green gelatine. "Lacunæ nullæ nee puncta stellata apparent in vivo glutine et mucore quodam viridi plus minus obducto."-Zool. Dan. iii. p. 6.

The Tethia cranium of Risso (L'Europ. Merid. v. 364) is altogether different from the British species.

\section{T. Lyncunium, globose, the surface warted, sparingly} hispid.

\section{Woodeut, No. 12.}

Tetie sferica, con superficie da tubercoli semisferici formata, e con vertebra nel centro, Donati, Nat. mar. dell' Adriat. 64, tav. 9. fig. A. B. $c$.

Alcyonium aurantium, Pall. Elench. 357. Esper, Alcyon. tab. 19, fig. 4-8: copied from Donati.

Alcyonium Lyncurium, Lin. Syst. 1295. Turt. Gmel. iv. 653. Lamour. Cor. Flex. 343. Corall. 246. Bosc, Vers. iii. 159.

Alcyonium Cydonium? Jameson in Wern. Mem. i. 563. Stex. Elem. ii. 432.

Spongia verrucosa, Montagu in Wern. Mem. ii. 117, pl. 13, fig. 4, 5 . Tethya Lyncurinm, Lam. Anim. s. Vert. ii. 386: ii. 592, 2de edit. Risso, L'Europ. Merid. v. 363. Blainv. Actinol. 544, pl. 91, fig. 3? Delle Chiaie, Anim. s. Vert. Nap. iii. 116.

Tethya verrucosa, Gray, Brit. Pl. i. 362.

Tethya sphrrica, Flem. Brit. Anim. 520. Bellamy's South Devon, 268.

Cydonium Mulleri? Flem. Brit. Anin. 516: Grant in Edin. New Phil. Journ. i. 195. Johnst. Brit. Zooph. 191.

Hab. Coast of Deron, Montagu. "Occurs in abundance attached to rocks and the under sides of stones in the long shallow bays of Cumnamara. I liave constantly found it on rocky points jutting out in the heads of muddy bays, where the colleetor will be nearly to his knees in mud passing from rock to rock. It lires at about half-tide mark," $M r$ William $M \cdot C o l l a$.

Sponge globous, usually contracted at the base, about an inch in diameter, compact and fleshy, of a clirty yellowish colour, the upper half corered with elosely set but equil flattish turbercles 
or warts, the lower part smooth and sliny, with a few bundles of spicula projecting at the root. The extent of smoothness at the base is regulated by the depth of mud in which the species grows immersed. There are no oscula nor pores, and the spicula either do not project beyond the surface or only sparingly and to a slight extent. The inside is fibro-fleshy and yellowish brown. The mucleus is usually excentrick and near the basc, whence the bundles of spicula rise, like ligaments, to the circumference, passing through the soft parenchyma and enlarging towards their terminations. This arrangement is rery well represented by Donati, at Fig. I. of the plate quoted in our synonymes. Many of the spicula pass through the skin, which is cartilaginous and about one-tenth of an inch in thickness, but becoming thin or obsolete on the smooth basal portion. The spicula are exceedingly profuse, fasciculate, slender, smooth and fusiform, obtuse and rounded at one end, while the other is pointed and sharp. They vary in length, , are mostly straight, but some are curved, and in most a central cavity can be distinctly seen. The spicula of the skin are shorter than those of the body, and in the spaces between their fascicles there are likewise found, although in no great numbers, some curious stellated spicula, somewhat like those of a Grantia. (Plate I. Fig. 10.) Tricuspidate spicula I did not detect amongst them.

I have had this species sent me as the Cydoxium Mulderi of Fleming, and I believe it to be the same, for it may be observed that the description, in the "Hist. of British Animals," is taken from a dried specimen, in which, it is admitted, that the cells leading from the stellate pores were indistinct.* The Alcyonium

* Dr Grant's description of the spicula of the Cydonium Mulleri is, however, opposed to this conjeeture. He says,_ "we observe the interior composed of two forms of spieula; one slender, long, and fusiform; the other thick and branched at one end into three short eurved rays; and the outer covering of the zoophyte is composed of regular minute 
Cydonium of Muller, Zool. Dan. tab. 81, fig 3, 4, 5, is undoubtedly nothing but the yellow or orange-coloured variety of $A l \mathrm{ry}$ onizum digitatum.

The figure of Blainville gives a very erroneous idea of this sponge, and seems to have been drawn from a specimen of a tuberous compact Halichondria, some of which have been admitted into this genus. The Tethya lacunata of Lamarck affords, as $I$ think, an example of this remark, provided the figure of Schweigger's Beobachtungen, pl. 2. fig. 16, 17, represents that species, though I am aware that Schweigger himself quotes the species as the type of the genus.

The Alcroxium Bursa of Esper, Alcyon. tab. 8, is apparently founded on a dried specimen of the Tethea Lyncurium. I have a portion of a specimen from Torbay in Deronshire, presented to me by Dr Coldstream of Leith, which resembles Esper's figure so closely as to make their specific identity scarcely disputable. But the Alcronium Bursa of Pullas (Elench. 352,) and of Lamarck (Anim. s. Vert. 2de edit. ii. 608), is now generally acknowledged to be a vegetable production. See Greville's Alg. Brit. Inart. 186.

siliceous balls, precisely as figured and described by Donati in the Alcyonium primum Dioscordis."-Perhaps two allied species may be here confounded, for the description of Dr Grant seems plainly to be derived from a Tethea.

Fig. 12.
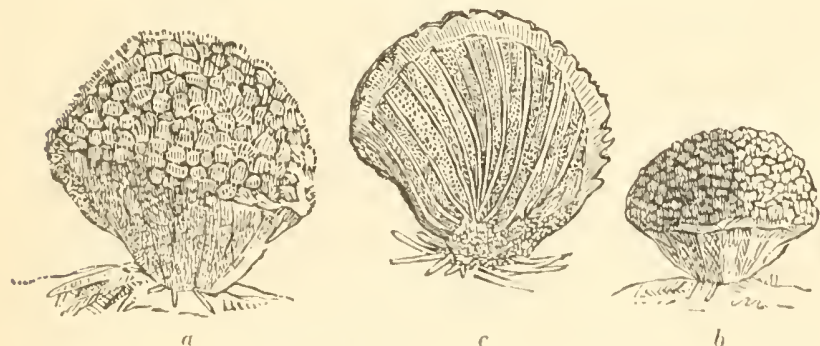

TITHLA I,Neven 


\section{HALICHONDRIA, Fleming.}

Halichondria, Frem. Brit. Anim. 520.-Halina, Grant in Edin. Encyclop. xviii. 844.-Haliclona, Grant, Outl. Comp. Anat. 5. -Halispongia, Blalnv. Actinolog. 532.

Character. Body multiform, more or less spongious and clastic, often friable when dried, permeated by canals opening by oseula on the surface, composed of fibro-corneous and siliceous threads woven into an irregular net-work, or of siliceous spicula variously crossed and netted together by a gelatinous cement; surface porous, usually more compact in texture than the interior, and not slimy: spicula simple, crystalline. Marine.

Tile name of the genus, says Dr'Fleming, is derived from

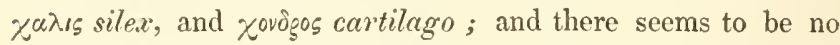
good reason for adopting the alterations of it which Dr Grant and De Blainville hare proposed. It is, upon the whole, an artificial group, embracing species which would never have been brought under one head, had their form or apparent structure guided us in the collocation of them; and, accordingly, we find the species scattered by authors through the genera Spongia, Alcyonium, and Tethea, or collected under other and new generic names. Eren in regard of their composition, the Halichondrix exhibit very considerable diversity, but they pass into one ano- 
ther by such insensible gradations, that the differencescan scarcely be deemed of generic value, though I have availed myself of them in distributing the species into sections.

The essential character of Halichondria is the existence of siliceous spicula in the fibre or parenchyma of the sponge, not collected into radiating fascicles but equally distributed throughout its homologous body. "The spicula are generally united into fasciculi by an enveloping glutinous or condensed cellular substance, and by the junction of these fasciculi in various modes, fibres are formed which traverse every part of the body, forming the boundaries of canals and orifices, and giving form and support to the whole of the gelatinous or soft cellular substance of the animal."-(Grant, Comp. Anat. p. 5.) These spicula, so far as the British species are concerned, seem to be always in the shape of simple needle-like crystals, nor does any specics present us with spicula of two different forms, thongh they sometimes vary much in length and gracility, but I cannot assent to the opinion of Dr Grant, that the form is different in every distinct species. Were this so, the task of defining them and tracking them through their protean guises would be easy, but my present experience makes me suspicious of a test, the value of which has not been proved by any extensive series of examinations.

The structure and consistency of the sponge is nearly uniform throughout the mass, but in many species the texture is closer and denser at the surface, which often looks, after being dried, as if it were coated over with a white skin or membrane. The ghntinous fluid is usually sparing in quantity, so that dried specimens exhibit in general faint traces of its existence.

It is in Halicondria that the circulation peculiar to the sponges has been principally observed, and the crustaceous species are best adapted for the study of its phenomena. A single observation is sufficient to convince us that this circulation has nothing 
in common with that of higher animals; but it has some ana. logy surely with that imbibition and influx of water into the body of most radiated and molluscous animals which takes place through the skin and throngh certain canals which Delle Chiaie has described and distinguished as their aquiferous system. 'The canals, in both eases, are not vascular tubes with membranous parietes but rather furrows excarated in the flesh or substance of the body, and leading into wider chamnels equally unlined : they have in common a direct communication with the circunfluent water, which alone ever flows in them; and the entrance of this water seems to be in a great measure, or entirely, independent of the will of the animals, but the polypes and mollusca only have the power of expelling it when they choose by the contraction and compression of the parts which the canals traverse. There is, however, a wider differcnce in the arrangement of the aquiducts in the two classes:in the radiata and mollusca the pattern is the same in every individual of each species; but in the sponges it has no constancy, so that in no two specimens of the same species do we ever find the arrangement to be exactly alike.

This inconstancy seems to prove that the direction of the aquiducts through the sponge, and the position of their orifices or oscula on the surface, is very much a matter of chance; and that their formation is the result of a mechanical cause liable to be diverted from its course by exterior circumstances. If we follow the growth of a sponge we may feel still more confirmed in this view. The species begins as a spot-like crust of uniform texture, porous throughout, and nearly equally so. In this primitive homologous condition, there is nevertheless a perfect circulation, - a current which seeks the interior and another which flows from it to mix with the circumfluent medium. As the sponge grows in extent and depth the space for imbibition secnlarged; and the contrifugal water, in its effux, flowing at first 
into one and then into more currents, these gradually make for themselves chamels in the cellular texture, the fibres of which are pushed aside and prevented, by the continuance of the stream, from again encroaching on its course. The channels increase in number with the continued increase of the sponge, and asit cannot but happen that they shall occasionally open into and cross each other, we have a wider canal formed by the additional flow of water into it. Such of these canals as reach near the surface soon effect for themselves an opening there, for the current in it pushes against the superficial coat which opposes its efflux, and gradually thins and loosens its texture until this ultimately disappears, leaving a fecal orifice or osculum. This is frequently a simple circular hole; but often, on looking within the outer rim, we notice in the funnel from two to five lesser oscula united together, which are the openings of so many canals that have united there; and sometimes we find spread within the osculum, or over its mouth, a net-work of finer texture than the rest of the sponge, but otherwise of the same nature and composition.

Such we believe to be the manner in which the canals and oscula are formed, and hence we cannot give our assent to the notion that the net-work spread over or within them is intended as a "wise provision" against the intrusion of noxious animals or other foreign bodies within the sponge, which scems indeed to be sufficiently protected at these orifices by the efflux of the currents passing continually from them. Neither can it be supposed that the position and elevation of the oscula have any foreseen relation with the situation of the sponge in the water. When, according to Dr. Grant, this production spreads level on a rock with an upright aspect, the oscula are raised into craterlike cones to enable the sponge to clear itself of the excremential matters earried out by the centrifugal streams; but when it haugs pendant from the rock, the oscula do unt rise beyoud 
the surface, because the necessity of ejceting the excremential matters to a distance does not exist. This is to bestow a foresight and instinct on the sponge, which even the followers of Lamarck would hesitate to give it, and which we may safely deny it to be possessed of. The form of the oscula depends entirely on the texture of the species and on the force of the effluent currents. If the texture is loose and fibrous it yields easily, and the oscula are level or nearly so ; if more compact the skin is pushed beyond the surface into a papillary eminence; and if too firm and dense to yield to the pressure behind, the oscula fall again into a level condition. They are also liable to be modified in some degree by external forces, for the littoral sponge, which, in a sheltered hollow or fringed pool, will throw up cratcrs and cones from its surface, may be only perforated with level oscula when it is swept over and rubbed down by the waves of every tide.

That some Halichondriæ are propagated by ciliated coloured ova is proved by Dr Grant, but I cannot concur in the conclusion that all the species have the same genesis. Surely were it so, ova would sometimes have been found in some of the numerous specimens of the many species which I have examined, but evidence of their presence has been in vain sought for. The growth of the species is certainly rapid, and many of them are annual.

* Texture fibro-reticular; the spicula imbedded in the fibres.

1. H. Palmata, arbuscular, irregularly branehed, the branches broad and compressed, with scattered oscula; texture rather coarse, rigid, and tongh; spicula short, donblepointed.

Plate II.

Spongia palmata, Sibb. Scot. ill. ii. lib. iv. 55. Ellis and Soland. Zooph. 189, pl. 58, fig. 6. Turt. Gmcl. iv. 659. Turt. Brit. 
Traun. 209. Jumeson in Wern. Mem. i, 562. Montagu in lbid. ii. 80. Bosc, Vers, iii. 172. Stew. Elem. ii. 434. Lam. Anim. s. Vert. ii. 379; and ii. 569, 2de edit. Lamour. Cor. Flex. 75. Corall. 181. Parkins. Oryctology, 46. Stark, Elem. ii. 424. Spongia bacillaris, Lin. Syst. 1299. Mull. Zool. Dan. prod. 256.

Turt. Gmel. iv. 659. Lamour. Cor. Flex. 83. Corall. 186.

Bosc, Vers, iii. 171. Parkins. Oryct. 48.

Spongia oculata, Esper, Spong. tab. 1, fig. 1, 2.

Manon oculatum, Schweig. Handb. 422.

Tupha palmata, Gray, Brit. Pl. i. 355

Halichondria palmata, Flem. Brit. Anim. 523. Johnston in Trans. Newc. Soc. ii. 269. Bellamy's South Devon, 268.

Halispongia palmata, Blainv. Actinol. 533, pl. 93, fig. 4.

Hab. In deep water on different parts of the coast from Devon to Zetland, Fleming. Found on the sea beach at Brighthelmstone in Sussex, Ellis. Orkney and Shetland Islands, Jameson. Coast of Devon, rare, Montagu. Near Holy Island, and on some parts of the eoast of Berwickshire, $G . J$.

Sponge plant-like, rising from a spreading base to the height of occasionally nearly two feet, variously branched, often in a somewhat palmate manner, the branches ereet, about an inch in breadth, thickish, compressed, often inosculating and inarching, of a straw-yellow colour, roughish to the feel, and rather unyielding when dried: texture fibro-reticulate, elastic, the fibres coarse, radiating upwards and towards the surface, forming an irregular net-work with angular meshes: the oscula round, numerous, seattered over both sides, with their margins level or slightly raised. The fibre is smooth, but of an unequal thickness, being generally enlarged at the points of anastomosis. The spicula are imbedded in it, mostly laid in parallelism, and a few protrude their points at irregular intervals : they are rather short, more or less curved, tapered to an acute point at each extremity, but, being easily brokell, many of them appear to be awl-shaped when freed from their matrix.

This is the largest and the finest of British Sponges. It is 
the "Mermaid's glove" of the Shetlanders. The Spongia palmata of Templeton in Mag. Nat. I list. ix. p. 470, is a variety of Italichondria panicea.

2 H. ocuLATA, erect, much and dichotomously branched, the branches rounded; texture fine and soft, with a smooth surface; fecal orifices small, mostly marginal ; spicula short, straight or very slightly curved, sharp at each end.

\section{Plate III.}

Spougia ramosa, Raii Hist. i. 81 : and Syn. 29, No. 1.

Spongia ramosa apicibus acutis furcis, Petiv. Pterigraph. Amer. tab. xix. fig. 3.

Branched English Sponge, Ellis Corall. 80, No. I, pl. 32, Fig. f. F. Phil. Trans. abridg. xii. 261, pl. 7. B.

Spongia oculata, Pall. Elench. 390. Lin. Syst. 1298. Ellis and Soland. Zooph. 184. Berk. Syn. i. 213. Turt. Gmel. iv. 658. Turt. Brit. Faum. 208. Stew. Elem. ii. 434. Montagu in Wern. Mem ii. 78, pl. 6, fig. 2. Lam. Anim. s. Vert. ii. 378. 2de edit. ii. 569. Bose, Vers, iii. 170. Hogg's Stock. 39. La. mour. Cor. Flex. 74. Corall. 121. Parkins. Oryct. 46.

Tuplaa oculata, Gray, Brit. 1'. i. 354.

Sp. dichotoma, Lin. Syst. 1299. Mull. Zool. Dan. prod. 256. Ellis and Soland. Zooph. 187. Berk. Syn. i. 213. Turt. Gmel. iv. 659. Montagu in Wern. Mem. ii. 82. pl. 6, fig. i. Lamour. Cor. Flex. 67. Corall. 177. Parkins. Oryct. 45. Lam. Anim. s. Vert. ii. 375 : 2 de edit. ii. 566. Bosc, Vers, iii. 171. Spongia polychotoma, Esper, Spong. tab. 36.

Tupha dichotoma, Gray, Brit. Pl, i. 355.

Halichondria ramosa, Flem. Brit. Anim. 523. Bellamy's South Devon, 268.

Haliclona oculata, Grant in Ontl. Comp. Anat. 5, Fig. 2.

L'Haléponge raneuse, Blainv. Actinolog. 533.

L'H. paniforme, Blainv. Atlas, pl. 93, fig. 5.

Hab. "Hanging from the under surface of rocks about the low-water mark of spring-tides," Fleming. "It is found very common all round the sea-coast of these kingdoms," Ellis. "Mare inter Angliam et Belgium," Pallas. Coast of Devon, Montagu. Dublin Bay, A. H. Hassall. It is not uncommon on the Northumberland coast; and occurs frequently in the Frith of Forth. 
Sponge arbuscular, crect, from 6 to 10 inches in height; the stalk compact, harel, cylindrical and usually short, dividing in a sub-dichotomous mamer into numerons mequal branches, which often inosculate or are connected by lateral shoots; they are roundish, obtuse, of a straw-yellow colour, smooth, soft, and woolly to the touch, elastic, of a fibro-reticular texture, the fibre slender, smooth and translucid, radiating from the centre upwards and outwards, and forming by its inosculations tetragonal or pentagonal meshes, so small as scarcely to be visible with the naked eye: fecal orifices rather small, generally not numerous, mostly disposed along the margins, but a few are? often scattered over the surface, especially where the branches divide. The spicula are short, stout, cylindrical, with acute ends, which are both alike.

The remarkable specimen represented in our plate was found in the Frith of Forth, and presented to me by my friend Dr P. WV. Maclagan. It grows from the back of a small crab (Hyas aranea), - a burden apparently as disproportionate as was that of Atlas, - - and yet the creature has been seemingly little inconvenienced with its arboreous excrescence, for it is big with spawn in a state nearly ready for laying ! Indeed the protection and safety which the crab would derive from the sponge might more than compensate the hindrance this opposed to its freedom and activity. When at rest its prey might seek without suspicion the shelter afforded amid the thick branches of the sponge, and become easy captives; - while when in motion scarce an enemy could recognise it under such a guise, and the boldest might be startled at the sight of such a monster :

$$
\text { - - - - methought, }
$$

The wood began to move!"

The Spongia dichotoma of Esper, Spong. pl. 4, fig. 1, 2, which is made a variety of this species by Lamarck, appears to us to be distinct. 
3. H. CERVICORNIs, stulked, dividing dichulomously into roundish erect branches of tou-like appearance, covered with pointed hairs : spicula short, acute at bolth ends.

\section{Plate IV. and Plate V.}

Spongia ramosa, Ger. Herb. en. 1577, No. 9. Merr. Pin. 116.

Downy branched English sponge, Ellis in Phil. Trans. abridg. xii. 261 , pl. 7, fig. C.

Spongia cervicornis, Pall. Elench. 388.

Sp. stuposa, Ellis and Soland. Zooph. 186. Turt. Gmel. iv. 659.

Turt. Brit. Faun. 208. Jameson in Wern. Mem. i. 562. Montagu in Ibid. ii. 79, p!. 3, fig. 1, 2; and pl. 4. Stew. Elem. ii. 434. Bosc, Vers, iii. 172. Lamour. Cor. Flex. 78. Corall.

183. Parkins. Oryct. 47. Lam. Anim. s. Vert. ii. 381. 2 de edit. ii. 572. D. Chiaie, Anim. s. Vert. Nap. iv. 150.

Tupha stuposa, Gray, Brit. Pl. i. 354.

Spongia lanuginosa, Esper, Spong. tab.24, fig. 1, 2. Lam. Anim. s. Vert ii. 379 : 2de edit. ii. 570. Lamour. Cor. Flex. 75. Co. rall. 181. Parkins. Oryct. 46.

Spongia echidnæa, Lamour. Cor. Flex. 68. Corall, 177.

Var. B._" With very slender dichotomous brunches, digitated at their summit ; the surface granulated."

Spongia digitata, Montagu in Wern. Mem. ii. 84, pl. 7. Flem. Brit. Anim. 525.

Tupha digitata, Gray, Brit. Pl. i. 355.

Hab. On the shore at Hastings in Sussex, Ellis. Coast of Devon, rare, Montagu. Above Queensferry, and Leith shore, Jameson. On the shore of Belfast Lough, Templeton. Dublin Bay, W. H. Harrey.

Sponge erect, plant-like, about a span in height, affixed by a fibrous base, stalked, dividing in general after a dichotomous fashion into cylindrical branches which spread out laterally, and have either simple or forked extremities, of a fibro-reticular texture, and tow-like appearance; the upper branches soft and transparent,- - the lower parts of the sponge and stalk firmer and opaque, and generally twisted: colour yellowish-brown : fecal orifices few and inconspicuous.-The reticulation of the 
sponge is as usual formed by longitudinal and cross fibres connected together and inosculating in every direction, so as to form irregular meshes or pores: the fibre itself is smooth, pellncid and tenacious, so that, when a piece is torn off and placed under the microscope, no detached spicula appear, and they can only be loosened from their glutinous matrix by heat or nitrous acid. They are short, thickish, straight or slightly curved, and pointed equally at both ends.

"What is considered as an elegant slender varicty of this species is beautifully white, and has the branches more ascending and more tomentose. Perhaps it is the older specimens that become palmated at the divarications, like the antlers of a buck. Both these sponges may be likened to the horns of a deer in their soft or velvety state, and one is probably the Spongia cerricornis of Pallas." Montagu.

Montagu gives the following description of his SP. DIGITATA : "This very slender sponge is tough and flexible; neither" the stem $110 r^{\circ}$ the branches are so large as a medium straw, slightly compressed: the branches are distant, and usually terminate in a cluster like the foot of a bird ; these slender terminal divisions are from three to six in number. It is compact in its texture, and when examined under a microscope, appears granulated on the surface as if sprinkled with fine sand: the base of the stem is usually ferruginous, the rest of a pale yellow-brown."

Dr Fleming considers $I$. cemicomis to be a rariety of $\boldsymbol{H}$. oculata, and I have seen specimens which favour this opinion, but in general their distinetion is easy enough. The spicula are alike in both.

The Spongia fruticosa of Esper, Spong. pl. 10, fig. 1, 2, is allied to, or perhaps identical with this species; but the SP. Murrcata, Lin. to which Esper's figure is referred by Lamarck, is very different, and a native of the coast of Africa. I know not by what oversight it has happened that the SP. STUPOSA of 
Solander should be quoted as a synonyme of $S$ p. murircta in the sccond edition of Lamarck's great work.

Esper's Spongia stuposa, tab. 40, is also different from our sponge. It is said by Lamarck to represent Sp.tupha.

The Spongia digitata of Templeton in Mag. Nat. Hist. ix. 470, is founded on an old and injured state of Antennularia antemnina.

4. H. IIISPIDA, "with long, slender, round dichotomous branches, covered with stiff hairs;" "spicula linear, coarse, and obtuscly pointed."

Spongia hispida, Montagu in Wern. Mem. ii. 86, pl. 5, fig. 1, 2. Tupha hispida, Gray, Br. Pl. i. 355.

Halichondria hispida, Flem. Br. Anim. 52.2.

Hab. Coast of Devon, rare, Montregu.

"This slender branched sponge appears as if it sometimes grew horizontally on each side from the point of adhesion, which is very slight; in this ease, both ends become branched. Others rise perpendicular from the base, which is attached to old shells; in some instances sereral stalks originate from the same spreading base, but are rarely connected: the branches are nearly round, except where they divaricate. Three, and sometimes four subdivisions take place in the larger specimens ; the points of the subdivisions are subacute. Length, a foot or more._When recent, contains a great deal of gelatinous flesh, and is of a yellowish-brown colour, becoming darker as it dries. 'The only specimens that have oceurred, were taken off the coast of Devon by the trawl; rare.

"The description given of S. tupha would tolerably well accord with this, had not that species been stated to be soft. whereas this is hard, and not composed of so fine a texture as S. oculata, and is thickly murieated with hairs." Montugu. 
5. H. ? RAMOSA, "palmated and digitated round the top."

Spongia ramosa, Montagu in Wern. Mem. ii. 84, pl. 8. Flem. Brit. Anim. 526.

Tupha ramosa, Gray, Brit. Pl. i. 35.5.

Hab. Near Weymouth, Mr Boyer. Coast of Deron, Montagu?.

"This curious sponge is stiff and somewhat elastic : the interior" part is ligneous, striated longitudinally, and which is always bare at the ends of the ramifications, where it seems to be composed of numerous fibres that frequently split and divide into fascicles : the spongy or exterior part is of a fine texture: colour pale yoilow-blown.

"This singular species, which appears to be undescribed, I first noticed in Mr Boyer's cabinet of British shells, chiefly found at Weymouth. I have since taken a larger and more perfect specimen on the coast of Devon, measuring nearly five inches in height." Montrgu.

6. H. Montagui, sponge with a spreading base, irregularly branched, the branches tubular, brittle when dried; spicula linear, sharp at both ends.

\section{Plate VI. Fig. I.}

Spongia tubulosa, Montagu in Wern. Mem. ji. 91: Templeton in Mag. Nat. Hist. ix. 471.

Spongia semitubulosa? Lam. Anim. s. Vert. ii. 380. 2de cdit. ii. 570. Lamour. Cor. Flex. 76. Corall. 182. Parkins. Oryct. 46. Scypha tubulosa, Gray, Brit. Pl. i. 357.

Halichondria Montaguii, Flem. Brit. Anim. 522.

Hab. Not uncommon in the estuary of Kingsbridge at very low water, adhering to stones, and is occasionally taken by the trawl in the open sea on the coast of Devon, Montagu. Cunnamara and Dublin Bay, William M'Colle. 
The most periect specimen of this species which $I$ have seen was sent to me from Dublin Bay by Mr Hassall. It is an irregularly branched sponge; the branches, rising from a shapeless spreading base, are erect or variously spread and curved, round and fistular, when entire with rounded and more solid extremities, but usually broken short, for they are very brittle at least in their dried condition. Texture fibro-reticular, resembling that of $\mathrm{H}$. oculata. Oscula large, circular, either terminating the branch or placed along its side in an uneven line. In the former case they frequently appear to be axillary, for the growth of the brancli having been arrested, other branchlets shoot out from the sides just under the osculum. Spicula fusiform, curved, rather short, and acutely pointed at both ends.

Since, however, specimens are rarely so perfect as the one which has served for om figure and description, Montagu's description of its more usual appearance is added. "The external structure of this sponge," he says, " is so fine as not to be discerned by the naked eye; smooth, and destitute of any detached fibres; when examined by a lens, it is observed to be finely, though irregularly reticulated with smooth fibres: the tubes are hollow throughout, nearly erect, and most commonly originate from a common base, but frequently so close together, as to become more or less united; sometimes smaller tubes issue from the sides of the larger : at the summit the tubes are as thin as paper." - " It rarely exceeds three inches in height, and four or five inches wide; one specimen contains ten principal tubes of different lengths ; the colour when fresh is yellow, but, by drying, it becomes of a pale brown or dirty white."

H. Montaguii is a littoral species growing rear low-water mark amid Corallina officinalis. It is often of the usual yellowishbrown colour of sponges, but is sometimes of a reddish-pink hue, resembling in this respect the $H$. oculata, of which I was at one fime inclined to supect this might be merely a variety,-the re- 
markable tubulous condition of the branches originating in unascertained local causes,--but the,observations of Mr Bowerbank have satisfied me that the suspicion is groundless. This excellent naturalist and micrographer, who did me the farour of making a comparative examination of the two species, writes me thus; " The spicula of H. oculata are thinner and somewhat straighter than those of H. Montaguii, and the cartilaginous fibre surrounding them is more perfect and abundant. The specimen of $\mathrm{H}$. oculata is a perfect skeleton, while that of both specimens of $H$. Montaguii is covered with the fleshy matter of the sponge. The two specimens of Montaguii agree perfectly with each other, and are certainly a different species from $H$. oculata, not only on account of the variation of structure mentioned above, but there is a general aspect which is difficult to deseribe, but which is sufficiently striking when seen with a power of 500 linear to impress the idea of their difference immediately upon the mind."

Montagu referred this species hesitatingly to the Spongia tubulosa of Solander (Ellis and Soland. Zooph. 188, tab. 58, fig. 7.), from which it is undoubtedly distinct, and hence Dr Fleming conferred on it the surname of the eminent discoverer, whose essay on sponges, I may take this opportunity of noticing, Lamouroux has ascribed, with culpable carclessness, to Mr Donovan. See Encyclop. Meth. art. Vers, ii. 327, \&c.

7. II. Colunise, "irregularly lutticed by rounded inosmlating branches ; spicula double-pointed and curved."

Spongia Columbre, Walker, Essays, 96.

Spongia cancellata, Sow. Brit. Misc. 131, pl. 60. Montagu in Werı. Mcm. ii. 110. Turt. Brit. Fauı. 208.

Scypha cancellata, Gray, Brit. Pl. i. 358.

Halichondria Columbe, Flem. Brit. Anim. 521.

Hreb. South shore of Icolmubil, Walter. Brighton in Sussex, $\mathrm{Mr}_{r}$ Fellous.

"It is of a rouml compressed shape, and about fou inches 
in diameter. Its substance is very tough, yet soft, delicate, and elastic. It eagerly imbibes water and parts with it freely; and though never so often wetted and squeezed, suffers no alteration in its substance or figure. These properties would render it valuable could it be found in any considerable quantity, and, for many purposes, it would be much preferable to the common sponge of the shops.

"It consists of a number of partitions about a quarter of all inch thick, standing close together, and joined to each other in several places by inosculations. These partitions upon the under side, next the root, are imperforate, but upon the upper side, they are perforated by small round holes disposed over their surface."

"Of this fine sponge, which is different from all those in Linnæus's System or Ray's Synopsis, there was but one specimen found upon the south shore of Icolumbkil." Dr Walker.

" Branches about a quarter of an inch thick; pores mimute, angular; the orifices, seated ehiefly at the union of the branches, are conical, wide, with the margins not thickened. As this species is different from either the $S$. cancellata of Gmelin or Lamarck, I have ventured to change the name imposed by Mr Sowerby, for the term employed by Dr. Walker, in the conviction that the sponge referred to by both is identical." Fleming.

"This remarkable sponge was brought me fresh from Brighton by Mr Fellows, September 17th 1805. Its cancellated structure distinguishes it at first sight from all others that $I$ have seen either specimens or figures of, especially as British. Besides this structure in the general habit, its fibres are also cancellated or reticulated with a horny appearance when magnified. All spongix seem to betray more or less the habitation or nidus of some animal, in the general structure. The kneed appearance and the swelling at the bend of the knee, with the inverted conical aperture, give this assurance. It is rather astonishing that 
this circumstance has not been ascertained with any certainty." s'ourerby.

8. H. ? PLumosA, "irregular, rather soft and tough, when deprived of its gelatinous flesh, somewhat resembling compressed tou."

Spongia plumosa, Montagu in Wern. Mem. ii. 116. Flem. Br. Anim. 526. Gray, Br. P]. i. 361.

Hab. Coast of Deron, rare, Montugu.

"The texture of this sponge is not very fine, but loose, and prerious to light, not very unlike officinalis, but of a paler colour, and not so compressible and elastic : it is composed of small fimbriated or feather-like fibres that intersect each other, interspersed with larger pores. It has not been aseertained to what size this speeies grows, or to what it is naturally attached. One or two specimens only have oceurred. These are of a yellowish-white colour, about three inches high, and more than two inehes broad." Montugu.

I have had imperfect specimens of a sponge (Plate XII. Fig. 4,) sent me for this species which do not aceord with Montagu's description of it. Nor did a visit to the British Museum throw any light on the subject, for the collection of sponges made by Montagu does not appear to have been deposited, with his other colleetions, in that noble institution. It has thus beeome almost impossible to identify some of Montagu's species, or even to ascertain the proper genus of them.

9. H. FRLTICOSA, amorphous, coursely reticulate, the filves loosely netted, tough; the spiculu short, linear, obtusely printed.

$$
\text { PLate XIV. Fig. } 1 .
$$

Spongia fruticosi, Montagu in Wern. Mem. ii. 112, pl. 14, tig. 3, 4 . Gray, Brit. pl. i. 360. Grunt in Edin. New Phil. Journ. ii. 139, 13. 2, fig. 10: the spiculum, copied in Blaine. Actinol. pl. 94, fig. 10 . 
Spongria crispata? Esper, Spong. tab. 37, fig 1-3.

Spongia lichcuiformis, Lam. Anim. s. Vert. ii. 35t; 2de edit. ii.

543. Lamour. Cor. Flex. 22. Corall. 153.

Halichondria fruticosa, Ftem. Brit. Anim. 522.

Mab. In deep water. By no means uncommon on the westerin coasts of England, especially those of Dorset and Devon, Montagu. Cormwall, Mr Couch.

" This sponge is extremely light and elegant in appearance like a shrubby lichen: the fibres are very distant, so that a large piece is, in a dry state, pervious to light: it is rather more compact about the base, from whence it usually spreads into large lobes, which frequently have the vertical fibres somewhat radiating from the base, and the decussations more distant. From the sinuous appearance of the larger specimens, it seems to attach itself to the stalks of large fuci; but as it inhabits the deep amongst rocks, it has never fallen to my lot to procure a living specimen. After violent storms, it is frequently ejected, and then is sometimes at first brownish, but soon becomes white by the conjoined action of the sun, the air, and the water. In this state, when all the animal gluten has been completely removed, the fibres under a lens exhibit a silky or asbestine appearance, and seem to acquire a superior tenacity. The larger pieces of six or seven inches in length, and half as much in breadth, are rude, shapeless, and usually have the terminating fibres worn away. It is in such older specimens that Balanus spongia, described and figured in Testacea Britannica, makes a lodgement. The fleshy or gelatinous substance which fills the interstices of the ligamentous fibres of every sponge has not, that I am aware of, been deteeted in this species; from whence we reasonably infer that it comes from the deep, and that, though it may by some accident be removed from its uatural fixed abode, it is not ejected till it has lost much of its specific gravity by the decomposition of the fleshy parts, which, from analogy, we may 
conclude, are readily perishable. The inosculations of the fibres are extremely variable, and form very irregular reticulations. Besides these uniting fibres, it is thickly interspersed with more minute unconnected branches, arising from the sides and angles of the anastomosing fibres." Montagu.

The fibre is very unequal in thickness, and appears interruptedly striated under a high magnifier, from the spicula shining through the clear membranous gluten which cements them together. The spicula are very numerous, short, straight or curved, linear but obtusely pointed at both ends, and not truncate except when they are broken, which is mostly the case.

H. fruticosa, as Montagu remarks, agrees in many particulars with the Spongia lichenoides of Pallas, but the fact that the latter is a native of the Indian ocean, has prevented us considering them the same. H. fruticosa has a strong animal odour in combustion, whereas that which the $\mathrm{S}$. lichenoides exhales is regetable or nearly so.

* * Cellular like erumb-of-bread and friable when dried : the spicula lying in a gelatinous membrawe. (Nearly coequal with the genus Tragos of Schreigger, Handb. 422.)

10. H. INFUNDIBULIFORMIs, widely funcl-shaped, of $u$ uniform porous spongy texture; spicula lineur and pointed.

\section{Plate VI. Fig. 3.}

Spongia infundibuliformis? Petiv. Pterogr. Amer. tab. 19, fig. 6 . Spongia infundibuliformis, Lin. Syst. 1296. Mull. Zool. Dan. prod. 256, No. 3085. Esper, Spong. tab. 57, fig. 1, 2. Jameson, in Werı. Mem. i. 562. Turt. Gmel. iv. 657. Stew. Elem. ii. 433. Bose, Vers, iii. 168. Montagu in Wem. Mem. ii. 103. Gray, Brit. Pl. i. 359.

Spongia crateriformis, Pall. Elench. 386.

Spongia calyciformis, Lam. Anim. s. Vert. ii. 365. 2de edit. ii. 55j. Spongia Pocillum, Lamour. Cor. Hex. 45, (exclus. syn. Mull. et Fabric.) Corall, 166.

Halichondria infundibuliformis, $\mathrm{F} / \mathrm{cm}$. Brit. Anim. 524. 
Hab. Northem islands, rare, Fleming. On the shores of the island of Unst, Jameson; "I have also been informed that Mr Neill is in possession of a specimen which he found in Orkney," Montagu. Found near Cumbra, Rer. D. Landsborough.

Sponge forming a funnel-shaped cup about three inches high and the same in diameter, the cup gradually evolving from a very short stalk and rooted by a moderately spreading basc. The texture and colour is uniform and spongy, finely reticulated or rather porous, the walls about the eighth of an inch in thickness, and the rim brought to an edge, even, or sinuated or fissmed : surface even and alike on both sides excepting that the interior is more compact: oscula none.

The sponge has the appearance of a fibro-reticular species, but is not so, and the spicula lie rather loose in their subcorncous membrane in fascicles or crossways. They are all simple, but very unequal, for many are curved and pointed at each end, while others are considerably longer, nearly straight, rounded at one and tapered to a sharp point at the opposite extremity, like a needle. A few of the latter are flexuous.

This fine sponge is the British analogue of the Neptume's cup of the Indian Ocean, and while it is vastly inferior in capacity, is excells the tropical species in neatness of texture, and in sponginess. For the specimen from which our figure was drawn, I am indebted to the kind liberality of the Rev. Darid Landsborough of Stevenston in Ayrshire.

Pallas seems to have had more than one species in view when he drew up his description of Spongia crateriformis, but I camnot agree with Lamarck that the species of Linnæus is undeterminable or even donbtful. His description, taken in connection with the habitat, decides the sponge before us to be what he intended. "Habitat in M. Norregico. D. D. Gunneins.-Junior perfecte infundibuliformis: adultior rumpitur 
sæpius bifariam et plana evadit. Substantia minus S. officinali tenax." It is true most of the Limnean synonymes are erroneous, and of this number is the quotation of the SP. FoliasCENs of Pallas,-a species undoubtedly distinct. Neither has H. infundibuliformis any relation with the Spongia PocilLuM of Muller, (which is a species of Grantia) though confounded with it by Lamouroux, - an error in which he has been followed by the editors of the last edition of Lamarck.

11. H. ventilabrum, fun or funnel-shaped, with reticulated woody fibres, covered with a villous coat of hair-like spines, and large spongy pores.

\section{Plate VII.}

Sea-fan Sponge, Ellis in Phil. Trans. abridg. xii. 261, pl. 7, Fig. H.

Spongia ventilabrum, Lin. Syst. 1296. Mull. Zool. Dan. prod. 255. Ellis and Soland. Zooph. 188. Turt. Gmel. iv. 656. Jameson in Wern. Mem. i. 561. Montagu in lbid. ii. 105. Stew. Elem. ii. 433. Bosc, Vers, iii, 167. Stark, Elem. ii. 424. Grant in Edin. New Phil. Journ. i, 349; and ii. 122, pl. 2, fig. 5. copied in Blainv. Atlas, pl. 94, fig. 5.

Spongia zetlandica, Jameson in Wern. Mem. i. 561 .

Sp. ventilabriformis, Gray, Brit. Pl, i. 359.

Halichondria ventilabra, Flem. Brit. An. 523. Thompson in Ann.

Nat. Hist. v. 254. Bellamy's South Devon, 268.

Halisprongia ventilabra, Blainv. Actin. 533.

Spongia xerampelina, Grant in Edin. Phil. Journ. xiv. 116.

Var. a. SCYPIA, "rigid but not woody, originating from a corky base, and spreading into a cup; slightly cut and indented at the margin : pores fine."

Spongia Scypha, Mlontagn in Wern. Mem. ii. 107. pl. 15, fig. i. Sp. foliascens, Gray, Brit. Pl. i. 359.

Hab. In the islands of Unst and Fulah, Jumeson. In deep water on the Scottish coast: in Zetland teruned Ling-Hoods. 
Fleming. Nymph Bank, Ireland (1820) R. Ball. "Bovisand (near Plymouth,) Miss Hook," Bellamy.

"This sponge is extremely variable in form, forming an entire cup, becoming shallower with age, of upwards of a foot in diameter; or with a cup divided into irregular lobes at the margin, or split, and exhibiting a fan-shaped leaf; the base, by which it adheres to stones, is solid, and the stem is very short; the substance is thick at the base, becoming thimmer towards the margin; when old, the central part thickens, becomes reticular, with a brittle exterior covering, which may be rubbed off, leaving a skeleton not unlike some Gorgoniæ; the pores are of various sizes, those on the inside of the cup or leaf are larger and less angular than the external ones; the spicula are numerous, and much matted; the gelatinons matter abounds in the young portions, especially towards the margin, and produces a cracked surface when drying." Fleming.

I have preferred copying this description of Dr Fleming's to any I could have made, because, while it has been drawn from the examination of a larger number of specimens than I have seen, it yet answers very exactly to my more limited observation. I have also followed Dr Fleming in considering the Spongia Scypha as the younger state of Sp. ventilabrum; but the character of the former has been given separately, for Montagu is very confident this is so opposite to that of the latter as to prevent them ever being confounded.

The sponge appears to be almost entirely composed of siliceous spicula bound together by a little glutimous cement. The spicula are various in length and variously curred or flexuons, linear and truncate at both ends, but amongst them there are some shaped like a needle,-obtuse at one extremity and sharply pointed at the other. "Those forming the so-named woody veins of this species, lic close and parallel to each other in clense 
fascieuli, which are disposed in a longitudinal direction from the base to the apex of the sponge. And the spicula which form the loose porous surface, have one end inserted into the dense central fasciculi of the woody veins, while their opposite end projects outwards at right angles to these fasciculi. The warel direction of the remarkably long siliceous filaments of this sponge is a necessary result of the kind of basket-work they are employed to construct." Grant.

12. H. simulaxs, polymorphone, of a firm inelastic imperfectly cellular texture, uodulous, the surface even and mimutely porous; oscula scattered, large and circulur; spicula short, curved, sharp at both ends.

\section{Plate VIII.}

Var. «. erect, irregularly brancled. Fig 1, 2.

— $\beta$. creeping, ramose or nodulous. Fig. 3. Ilalispongia reptans, Scouler MS.

- 2 . papillary. Fig. 4.

- $\delta$. massive. Fig. 5 .

Hab. Coast of Cunnamara, $W^{\top} m$. $\boldsymbol{H}^{6}$ Colle. Dublin bay, $A$. H. Hassall.

This appears to be a good species but subject to more than ordinary variety in the forms it assumes. One is erect and shrub-like; another constitutes a creeping sponge about the thickness of the little finger, sparingly brancher or merely nodulous, with a large osculum in gencral on every knob; a third variety has a very exact resemblance to the teat of a quadruped; while in another state the sponge is amorphous, forming an irregularly knobbed mass or crust an inch or so in thickness, every elevation perforated as usual with its open cireular orifice. In all these states, howerer, the sponge is pretty uniform in colour and in textme. It is earthy yellowish-brown, firm and 
not easily compressed, non-elastic, the surface eren and porous, the interior irregularly cellular like crumb-of-bread, and friable when dried. The spicula lie in their subcorneous membrane crossedin every direction : they are short, stout, smooth, curved, eylindric with sharp extremities, and are nearly all of the same size and form. They are not unlike those of $H$. oculata but more curved.

The var. $\beta$. has a very peculiar mode of growth. Rising from its original site in the form of a knob, it extends laterally until the branch meets with an elevation on the rock to which it also roots itself; and thus it spreads, from point to point, until the sponge rests on knobs placed at irregular interrals, like the pillars of some rude rustic bridge, their number and position being apparently determined by the inequalities of the place of growth. A specimen of this kind somewhat resembles a small knobbed stick in a rottened condition. When the primary knob continues solitary we have the nipple-like variety, which, fixed by a spread base, rises to about an inch in height, having an enlarged rounded apex more widely porous than the stalk, and perforated with a single osculum.

H. simulans has an evident afinity with the Alcion ro ForAMinoso of Imperato, Hist. Nat.p. 641 ; but it is not the Spougia rubens of Pallas, nor the Sp. nodosa of Linnæus. Sposgia CLAvata of Esper, Spong. tab. 19, seems also related, both in texture and habit, to $H$. simulans.

"Forma Spongiarum infinite variat et in eadem sæpe specie adeo diversa observatur, ut vix agnosceres, nisi substantia, textura, intermediæque varietates facem præferrent." Pallas.

13. H. CINEREA, crustaceous, spongy, blackish-grey, umporous, the oscula few and obscure; spimila linear, emrorl, pointed at both ends. 


\section{Plate IV. Fig. 4, 5.}

Spongia cinerea, Grant in Edin. New Phil. Journ. ii. 204, pl. 2, fig. 3: (the spiculum) copied in Blainv. Actinol. pl. 94, fig. 3. Halichondria cinerea, Flem. Brit. Anim. 521.

Spongia cxrulea? Risso, L'Europ. Merid. v. 373. Delle Chimir, Anim. s. Vert. Nap. iii. 113, tav. 37, fig. 11.

Spongia pulveruleuta, Scouler MS.

Hab. Frith of Forth, very rare, Dr Grant. Cumnamara and Dublin Bay, Wm. $\boldsymbol{H} \cdot$ Colla and A. H. Hassall.

Sponge forming an irregular crust of a uniform hair-brown or ash-grey colour, about a quarter of an inch in thickness, soft and pulverulent when dry, and of a very fine sponge-like texture. The surface is even and smooth without visible pores, and the oscula are indistinctly marked. The structure is reticular, but the net-work is formed, not by a horny fibre, but by the spicula alone, which are disposed so as to become the frame-work of small quadrangular meshes of unequal sizes, held together by a very small proportion of glutinous matter. The spicula are similar to those of H. Montaguii but shorter and straighter. The species is evidently littoral, for the specimen before me has enveloped in its growth some leaves of the Zostera marina.

This sponge varies a good deal in colour, so that Dr Scouler's name for it is much preferable to that which it bears in right of priority, and has also the advantage of expressing the remarkable friability, which may be considered as the principal characteristic of the species when dried. It is thus deseribed by Dr Grant: - "I met only with a single specimen of this sessile species, about two years ago, in the Firth of Forth, and I have not since observed it on any other coast. It grew on the inclined side of a rock, had an irregular outline, and was about three inches in length, one in breadth, and half an inch in thickness. My attention was attracted to this specimen, from its perfect resen- 
blance to a dark putrid sponge, but on immersing it in water, I found it still in a high state of vitality. Its surface was smooth, convex, fleshy and transparent. Its pores required a lens to be distinctly seen, and its fecal orifices were few, very large, regularly circular, and lay rather deeper than the general surface. Its spicula were remarkably uniform in size, rather small, curved, equally thick throughout, pointed suddenly at both ends, and silicious."

14. H. Fuconum, amorphous, the texture fibro-cellulur, friable when dried; spicula rather short, slightly curved, more aculely pointed at one extremity than at the other.

Plate IX. and Plate XII, Fig. 2.

Spongia Fucorum, Esper, Spong. tab. 49, fig. 1, 2.

Spongia parasitica, Montagu in Wern. Mem. ii. 114. Gray, Brit.

Pl. i. 360. Grant in Edin. New Phil. Journ. i. 348.

Halichondria parasitica, Flem. Brit. Anim. 521. Thomson in Ann. Nat. Hist. v. 254. Bellamy's South Deron, 268.

Halispongia parasitica, Blainv. Actinol. 532.

Hab. "Investing fuci and corallines, not uncommon," Fleming. " Frequent on Sertularix, sometimes following the course of the branches individually, which it envelopes; at other times spreading laterally, and uniting the branches together, becoming an unformed mass : the texture is rather coarse, and the fibres fimbriated. Sometimes in large masses at the base of Sertularia antennina, and other vesicular corallines," Montagu. Near Hartlepool, Durham, J. Hogg. I have specimens from the western shores of England and Scotland; and from the number of specimens communicated to me, from various localities, by $\boldsymbol{M}$. W. Thompson, it appears to be common on the Irish coasts.

Sponge of no specific shape, fibrous, reticulated, homogeneous, of a greyish-white or yellowish-brown colom, inelastic, either 
softish and compressible, or firmer and harsh to the fecl. Fe.. cal orifices generally obscure or obsolete. Spicula very numerous, rather short, curved in a slight degree, sharp at one end and obtuse and rounded at the other: they are not all of the same length, and amongst those which principally compose the skeleton of the sponge are mixed some which are comparatively slender. The meshes are formed by the cross-layings of the spicula, which occasionally are so free of horny matter that their form can be detected without previous incineration or maccration in an acid. The degree of seftness in the species depends much on its habitat. When parasitical on Sertulariæ, which grow in a state of constant submersion, the texture is softer, looser and finer than when it is parasitical on the littoral sea-weeds ; and I have found the spicula in the former variety more unequal than in the latter, the common so:t being mixed up with others of greater slenderness and length. The texture of the littoral variety is like that of $H$. simulans, but more uniformly porous, and there are rarely any oscula. It is occasionally of a reddish colour, as are also H. palmata, oculata, and several other's of the genus.

To this speeies undoubtedly belongs the "sponginess" mentioned by Pallas under his description of Spongia crateriformis : - Massas simillimæ substantiæ, quosdam subturbinatas, informes, albidioresque habeo ex mari Antiquam Insulem alluente. Subsimilem quoque spongiositatem in sussexice littore in parris massulis, aut et Fuco pinastroidi immixtam observavi." Elench. p. 386.-And there is as little hesitation in saying that the "doubtful species" mentioned by Mr Templeton (Mag. Nat. Hist. ix. 471,) as " a good deal like Spongia lobata, Mont., of a. dark brown, and covering the stems of a piece of Fucus siliquosus," can be no other than a state of H. fucorum. I have even seen it in a crustaceous state, spreading on the surface of a rock, so very like the primary condition of II. palmata that the distiuct- 
tion could not have been made without an examination of the spicula.

15. H. PANICEA, incrusting, amorphous, compact, cellular like crumb-of-bread interiorly, the surface mimutely porous, even or pupillary; fecul orifices large and scattered; spicula, fusiform, slightly curved.

Pi.ate X. and Plate Xi. Fig. 5.

Halichondria papillaris, Flem. Brit. Anim. 520. Johnston in Trans. Newc. Soc. ii, 270. pl. 9, fig. 3.

Halispongia papillaris, Blainv. Actiıol. 532.

Var. $\beta$. Sponge forming a white leprous crust, covered with a skin reticulated like gauze when dried. (Plate $\mathrm{x}$. Fig. 1.) Spongia tomentosa? Lin. Syst. 1299. Turt. Gmel. iv. 659. Turt. Brit. Faun. 208. Stew. Elem. ii. 434. Bosc, Vers, iii. 171.

Alcyonium tomentosum, Templeton in Mag. Nat. Hist. ix. 470.

Var. $\gamma$. Crust thicker, even or irregularly raised, with a smooth surface; oscula level or on slightly elevated mammilla. (Fig. 2.) - Fucus marinus noster sinilis medullæ panis, Raii, Hist. Plant. iii. 16.

Spongia infon mis durior, compressa, Raii, Syn. i. 30, No. 7.

Alcyonium ranosum molle, medullæ panis intus simile, Raï, Syn. 31 , No. 1.

Sponge like Crumb-of-Bread, Ellis, Corall. 80. No. 2, pl. 16, fig. d. D. Phil. Trans. abridg. xii. 261, 261, pl. 7, A.

Spongia panicea, Pall. Elench. 388. Turt. Gmel. iv. 660. Lamour. Cor. Flex. 29. Corall. 157. Stew. Elem. ii. 435. Bose, Vers, iii. 173.

Sp. urens, Ellis and Soland. Zooph. 187. Hogg, Stock. 38. Templeton in lib. cit. ix. 47].

Sp. tomentosa, Moutagu in Wern. Mem. ii. 99. Jameson in Ibid. i. 562. Gray, Brit. Pl. i. 36]. Grant in Edin. Plil. Journ. xiv. 114.

Sp. urtica, Risso, L'Europ. Merid. v. 370.

Alcyonium papillosum, var. 2, Lamarck, Anim. s Vert. ii. 398. 2de edit. ii. 604 .

Alcyonium medullare, Lam. Anim. s. Vert. ii. 400. 2de edit. ii. 606. Templeton in Mag. Nat. Hist. ix. 470. Lamour. Cor. Flex. 35.5. Corall. 251. 
Alcyonimm paniceum, Lam. Anim. s. Vert. ii. 400) : 2de edit. ii. 607. Alcyonium tubulosim, Esper, Alcyon. 40, tab. 11, fig. 1, ‥

Var. $\delta$. The surface papillose, the papillie large, couical, and tubular, with a terminal osculum; texture often less compact, so that the pores are readily visible to the naked eye. (Fig. 3, 4, Plate xi. Fig. 5.)

Cock's-comb Sponge, Ellis in Phil. Trans. abridg. xii, 261. pl. 7 , fig. F.

Alcyonium manus diaboli, Lin. Syst. 1296. Esper, Alcyon, 66, tab. 21, fig. 1, 2; and tab. 22 .

Spongia cristata, Ellis and Soland. Zooph. 186. Turt. Gmel. ir. 659. Turt. Brit. Faun. 208. Bosc, Vers, iii. 172. Stew. Elem. ii. 434. Montagu in Werm. Mem. ii. 103. Lamour. Cor. Flex. 28. Corall. 156. Gray, Brit. Pl. i. 359. Templeton in lib. cit. ix. 471. Risso, l'Europ. Merid. v. 370.

Sp. papillaris, Montagu in Wern. Mem. ii. 90. Grant in Edin. New Phil. Journ. i. 343; and ii. 138, pl. 2, fig. 2, 21, 25, 26. Roget, Bridgew. Treat. i. 149, fig. 53.

Scypha papillaris, Gray, Brit. Pl. i. 357.

Halina papillaris, Grant in Cyclop. Anat. and Phys. i. 108, fig. 29 ; and Outl. Comp. Anat. 311, fig. 108.

Spongia compacta, Sowerly's Brit. Misc. 85, pl. 42. Turt. Br. Faun. 208.

Var. $є$. Sponge forming a solid roundislı wart-like or tuberous mass.

Fig. 5.

Hab. On rocks between tide-marks, on crabs, shells and corallines, and on the roots, stalks and fronds of the larger Fuci, very common; and seemingly met with on all parts of the Bri-. tish coasts in profusion.

Forms an irregular and often very extensive crust from oneeighth to nearly an inch in thickness, in general of an orangeyellow colour, sometimes with a considerable mixture of green, becoming greyish-white when bleached or dried, and covered with a sort of thin compact and reticulated epidermis. The sponge is rather firm, compressible but not clastic, porous and cellular, and perforated with canals which open on the surface, either level with it, or mammillary, or elevated into large papillary processes, that are either separate or confluent, and each of which is teminated by a wide feral orifice. We may often per- 
ceive four or five smaller orifices opening in the interior of many of these larger ones, the rim of which is always of denser structure than the rest of the surface, simple, circular and smooth. When broken longitudinally, the fibres of the sponge are observed to have an upright direction connected by numerous cross threads formed by fasciculi of the spicula, which are very numerous, short, curred, fusiform, and pointed at both ends.

Nothing can be more various than the appearances which $\mathrm{H}$. panicea assumes in different localities and sites. On sea-rreeds and corallines it often forms a thin crust which, after being dried, is of a snow-white colour, and may readily be mistaken for Grantia nivea without an examination of its structure. In its normal state the surface is smooth, even, ridged or lobed, with the pores so fine as to be imperceptible when the sponge is fresh, and just visible after it is dried, while the fecal orifices are scattered, either level or very little raised: this is very common on rocks near low-water mark, and often surrounds the stem of Laminaria digitata, nor is it uncommon on some crabs (Hyas and Inachus) which it often entirely envelopes.* Another va-

* My friend Mr William Thompson of Belfast writes me that he never saw a specimen of Inachus scorpio which was not invested with sporige. This reminds me of a curious habit of some Caribxan crabs detailed by the late Rev. Lansdown Guilding : " The crustaceologist does not seem to have accounted for the spurious legs, as he injustly calls them, in many genera of erabs, which appear in the works of European authors. 1 once imagined that they were solely connected with the oviposition of those curious beings, and in Lithodes arctica and the Porcellana (which so beautifully connect the short-tailed with the loug-tailed deeapor Crus$t_{\text {acea }}$ from their weakness and position they perhaps serve no other purpose. In the Dromia, however, and some other genera, they are quite dorsal, and wonderfully adapted to the purpose to which they are applied, that of holding their house upon their back, as the spurious posterior legs of the Paguri cling to the deserted shells they have seizerl for their retreat. I have lately captmed several specimeus of these dorsipedous Dromice laving on their back houses of sponges excavated and fitted to their shapes, under which they lie concealed while their prey approaches. In one species the lonse was inimitably cut, having loon- 
riery of the sponge is very unequal and raised into mumerous large conical or papillary processes perforated on the summits: and the texture being loose and more friable, the pores are very visible; and there are besides many large holes scattered over the surface. Grant's figure is not an exaggerated representation of it in one of these states; and Sowerby's figure of his Spongia compacta is a good representation of it in another, which is less common than the preceding. A specimen with the processes more than usually elongated, so that it has in fact become irregularly ramose, constitutes the Spongia oculata of Templeton, "found on the shore of Belfast Lough."

When growing amid Corallina officinalis or capillary seaweeds, H. panicea often hangs from a branch in nodulous masses that vary from the size of a pea to that of an apple. These are occasionally broken off and cast on shore, altered a good deal in appearance. Such specimens have been sent me as distinct species. To detect their true relationship no description can be made available, hut in general an attention to the structure of the mass, and to the figure of the spicula, will suffice.

When dry the sponge is friable, and the powder has the property of producing an intolerable itching when rubbed on the skin, as is well known to mischievous boys, "It is remarked, that if it is dried in an oven this peculiar property of stinging is much increased." Ellis.

That this species is the Spongia panicea of Pallas I consider to be indisputable ; but it surely camot be his Spongir papillaris, 1 st, because it is unlikely that the same sponge should be described twice under different names by a naturalist of Pallas' experience and caution : "Species Spongiarum nonnisi illas

holes for the eyes, and ridges on which the dorsal legs were fixed. The Sponge does not lose its vitality, though it is probably cut and modelled by the crab; a circumstance which would assist it in deceiving the animals on which it feeds." Zoologieal Jonrnal, iii. p. 406. 
hic recensebo, qux distinctos exhibuerant characteres quasque ex multis visis exemplaribus constantes esse intellexi." Elencn. p. $377 ; 2 d$, because the structure of Sp. papillaris is stated to be similar to that of Sp. oculata, the H. oculata of this work; and $3 d$, because Sp. papillaris is a natire of the American seas, for although the same sponge may inhabit the shores of Britain and America, yet experience has shown it to be more likely that the species, however nearly related, are really distinct. Each species even of the shapeless sponges has a local existence, and seems to have been originally produced only in one spot. See Prichard on the Physical History of Mankind, Vol. i. p. 51 -3. 2d edit. Lond. 1826.

Lamouroux was the first to point out the confusion in which Lamarck has involved this speeies, - a confusion which has been rather increased than otherwise by the editors of the last edition. Certainly Spoxg1a Panicea of Exper, Spong. tab. 18, fig. 1, 2, is not a synonyme of it, but apparently a species of Grantia. Probably, however, Esper's Spoxgia PAPIllaR1s, Spong. pl. 2, fig. 1, 2, is one of its rarieties; as is also apparently his Alcroxicy tuberculosun, Alcyon. p. 68, tab. 23 , fig. 1,2 ; and I hare no hesitation in regarding his $\mathrm{AL}_{\mathrm{L}}$ CYoNium tubulosum, p. 40, tab. 11, fig. 1, 2, as founded or that state of $H$. panicea produced by its surrounding the stalk of the Laminaria, when it forms a long tubular pipe on being withdrawn from the stalk, which can easily be done after the specimen is dried.

Limnæus' description of Alcyonium manus diaboli seems to me very applieable to $H$. panicea in that state which Sowerby described as Spongia compacta. "Habitat in Islandia. J. G. Konig. Corpus molle instar pulpæ siccatæ Lycoperdi, extus læve, superne protuberans digitis aliquot brevibus, obtusis, perforatis apice tamquam penna, ad medium usque rami."_- We must take eare, however, not to confound this with the Alcyoninm 
pistortum of Lamarek, for which the figures of Esper are quoted; for it is little probable that an Iceland sponge should extend its range into the Indian ocean.

For the following analysis of $\mathrm{H}$. panicea I am indebted to $\mathrm{my}$ distinguished friend, Dr R. D. Thompson.

\begin{tabular}{|c|c|c|}
\hline \multirow{2}{*}{$\begin{array}{l}\text { Organic matter, } \\
\text { Carbonate of lime, }\end{array}$} & - & 28.60 \\
\hline & , & 48.79 \\
\hline Siliea, & 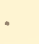 & 19.04 \\
\hline Phosphate of lime, & • & 2.38 \\
\hline Chloride of sodium, & & 1.19 \\
\hline Alumina, & - & a trace \\
\hline & & \\
\hline
\end{tabular}

16. H. egaGROPILA, amorphous, massive, fibro-reticular and friable when dried, covered with a ganze-like skin, perforated with numerous small mammillated oscula, and " few large irreyular scattered orifices; spicula needle-shaped.

Plate Xl. Fig. 1.

Halispongia ægagropila, Scouler MSS.

Hab. Oecurs adhering to stones or to the curions coral-like substances so abundant in the bay of Roundstone, Cumnamaral, ITm. $\mathrm{H} \cdot \mathrm{Coll}$ re.

Sponge growing in large amorphous masses more than an inch in thickness, very light, firm but compressible, inelastic and impermeable to light, of an earthy brown colour and coarse fibrocellular texture, the fibres radiating from the base upwards and formed, by their irregular inosculations, into rather large oblong eells filled with a spongy parenchyma. 'The surface, when the sponge is perfect, is covered over with a thin white cuticular membrane reticulated like gauze, but not porous, through which the fibres sometimes project in short spinous pounts. 'The proper nsenta are very numerous and small, and in the shape of 
perforated mammillæ; but there are besides, in most specimens, a few large orifices resembling the oscula of H. incrustans, being level with the surface and having a ragged or substellated rim.

This unseemly sponge is not brittle and less friable than either H. panicea or incrustans, to some varieties of which it has considerable resemblance; but it is always lighter and more fibrous, and the surface, thickly studded orer with its mammillated oscu$\mathrm{la}$, is very characteristic. When the cuticular membrane is, from any cause, destroyed, these are not of course apparent, but the surface becomes then coarsely and loosely latticed, exhibiting in fact the interior structure from which the parenchyma has been washed out. Such an appearance $H$. panicea and H. incrustans can never assume, for it is produced by the comparative toughness, and indestructibility of the coarse fibres which are peculiar to this species, These fibres may be compared to those of $\mathrm{H}$. fruticosa. They are tough, smooth, unequal in thickness, opake, and composed of numerous spicula laid in parallelism. The spicula are the same in shape as those which are found in equal profusion in the intercellular parenchyna and in the cuticular membrane, but where they lie crossed in every direction. They are needle-shaped,- that is onc extremity is rounded and obtuse, when, after a short space, the shaft becomes a very little thicker, and is brought to a sharp point at the opposite extremity. They are considerably longer than the spicula of $H$. incrustans, and unlike those of $\mathrm{H}$. panicea in shape, affording a certain test by which we can distinguish it from them under every mask it may assume.

17. H. SABURRATA, crustuceous, the surfuce latticed with larye amgulated open pores; oscula scattered, papillary; spiculu short, ruiled and double-pointed.

$$
\text { Plate XI. Fig. } 3 .
$$

Uab. Adheres to rocks in the Bay of Roundstone, Cun- 
namara, which are never left dry but during the spring tides of Wareh and April : of rare occurrence, $W m$. $W^{\circ}$ Colla.

Sponge forming an irregular thick crust cellular like crumbof-bread, harsh and firm to the feel, inelastic, friable when dry, the surface latticed with angulated or sinuous pores, not covered with a skin, but sometimes connected by a thin membrane formed by the drying of the gelatine: the oscula large, scattered, raised into crater-like papillæ perforated on the tops, with the thin rim scarcely more compact than the other parts. The boundaries of the pores are sinuous, rugous, and somewhat hispid from the projecting spicula. These are stout, short, slightly curved and pointed at both ends.

This so nearly resembles some varieties of $H$. incrustans that the form of the spicula can alone discover their distinctness, except the character derived from the oscula being papillary should prove to be constant. I know no other species with which II. saburrata can be confounded.

18. H. AREOLATA, encrusting, the surface even, latticed with angulated spinous cells; oscula none; spicula feu', rather short, curved and double-pointed.

\section{Plate XIII. Fig. 4.}

Hab. On the under surface of stones at low water-mark. Scarborough, Mr. Bean. Dublin bay, A. H. Hassall.

Sponge crustaceous, spreading irregularly, about one-eighth of an inch in thickness, of a brown colour, the surface even, honey-combed with large quadrangular or pentangular cells bounded by a thread-like line which, at every angle, forms a small spinous point: fecal orifices none: structure somewhat fibrous, and the fibres appear through a magnifier roughish as if encrusted with grains of sand. Specimens in the cabinet are rigid and friable, but when living the spouge contains a large 
proportion of gelatinous fluid which fills the cells and, on drying, forms a thin pellicle at the botton and on their sides.

This may possibly be the primary or erustaceous condition of H. rgagropila, but the surface of recent specimens is not coated with a skin, nor does the gelatine on drying form any thing similar. The fewness of the siliceous spieula is another remarkable diagnostick, for of this species the mineral ingredient consists prineipally of small unerystalline gravel, which is imbedded in the animal matter, and amid which the spicula are almost lost.

19. II. INCRUSTANs, irregular, extremely porous, rather lurd and brittle, like crmmb-of-bread or oftener like a picen of old urorm-eaten cork; oscula obscure, substellated, even witls the surface; spicula rather short, needle-shaped, straight or slightly curverl.

Plate XII, Fig. 3. and Plate XIII, Fig. 5.

Alcyonium incrustaus, Esper, Alcyon. tab. 15. Lam. Anim. s. Vert. ii. 397 : 2de edit. ii. 603. Lamour. Cor. Flex. 340. Corall. 244. Spongia fava, Montagu in Werm. Mem. ii. 115. Gray, Brit. Pl. i. 360.

Spongia panicea, Grant in Edin. Plil. Journ. xiii. 104; xiv. 118 ; and in Edin. New Phil. Journ. i. 347 ; ii. 128, 138, pl. 2, fig. 4, 24, 27-29, copied in Blainv. Actinol. pl. 94.

Halichondria panicea, Flem. Brit. Anim. 520.

Halispongia panicea, Blaine. Actinolog. 532.

Hal. On rocks within low-water mark. On roeks in the Firth of Forth, abundant; Island of Staffa, Dr. Grant. Searborough, Mr Bean. Coast of Devon, not common, Montugu. Plymouth, J. C. Bellamy. Shores of the Isle of Man, $M \cdot E$. Forles. Dublin bay, A: H. Hassull.

This unattraetive species has presented itself to me $(1 s t)$ in the form of a thick crust spreading irregularly over the rock; amel (2d) in isolatcd and detached masses of a roundish shape, 
and as large, or even larger than a goose's egg. It is less compact than the preceding and equally friable, more cellular interiorly, and the pores of the surface are large, unequal, irregular, inosculating and sinuous, while the oscula, rarely elevated, can in general only be distinguished from them by their superior size. These, moreover, have never any distinct rim, but are often cut in a somewhat stellated manner. The spicula are short, straight or slightly curved, rounded at one end and acutely pointed at the other.

Dr Fleming describes it as an extended crust "sometimes an inch in thickness; when dried, the surface is flat and very porous, and the orifices, which are rather sumk, have irregular margins, and the divisions of the interior canals being usually visible, give the openings a stellular aspect."

Montagu's description is as follows: "This sponge, though harsh to the feel, yields to the pressure of the finger-nail without elasticity : when recent, is orange-yellow, and full of gelatinous flesh, but when exposed for a time on the shore, and the fleshy parts decayed and washed out, the pores are observed to be roundish. When examined by a lens, has a slight resemblance to a honey-comb; the pores, however, are not regular in size. If taken fresh, and artificially dried, the pores are greatly obscured by the contracted gluten, and the colour becomes of a dark brown. If it has undergone a natural decomposition of the more perishable parts on the sea-shore, by the conjoined action of the water and the air, the pores are cleared, and it retains a light yellowish colour. A specimen in this state before me, is flat and broad; round the edges, (which appear to have been broken, ) there are many large round openings intersecting the smaller pores, and communicating with those on the flat surfaces. This piece is three inches long, two broad, and about half :un inch thick."

Dr Graut tells us that this is the species which preseuts the 
strongest currents, and which is therefore best suited for the observation of the peculiar circulation of the family. Its fecal orifices are not raised on papillary eminences, because, says Dr Grant, the sponge grows always on the under side of rocks looking down in the water, and hence an elevated crater, to throw off from the surface the excrementitions matters which are ejected from it, is unnecessary. "The fecal apertures are raised to the extremities of projecting papillæ, in such sponges as cover the sides of rocks, in order to convey the excrements beyond the pores and general surface of the animal. In the Spongia oculata, S. palmata, S. xerampelina, and such branched species as hare a soft downy surface, the fecal orifices are ranged in close order along the outer margins of the branches, and very few are observed on the flat surface, in order to prevent the excrement from falling in the direction of the flat woolly surfaces, which would be very apt to retain it, and thus choke up the groups of pores which are seen everywhere over their surface. Such branched sponges have not, and do not require, projecting papillæ, because they hang suspended by a narrow stem, and are kept sufficiently clean by receiving gentle undulations from the constant motions of the sea. The same applies to the soft downy white Spongia compressa, which akways hangs down, and whose orifices are always marginal. The bright yellow porous placentiform mass of the Spongia panicea has no papillæ; indeed, the fecal orifices are sometimes even lower than the general surface of the animal, and I have never seen this sponge excepting on the under surface of rocks, with its orifices perpendicularly downwards; so that the excrements fall clear of its surface by their own gravity, without the assistance of papille. The flat species which are found encrusting Fuci, Sertularix, Corallines, or other moveable bodies, have very seldom prominent papillæ, because they are clcansed by the agitations of the sea like the branched sponges." Gront. 
20. H. SERIA'ta, encrusting, the surfuce plane, smooth, porous; fecul orifices level with the surfuce, in regular close runges; spicula short, slightly curved, more pointed at one end than at the other.

\section{Plate XIV, Fig. 2.}

Spongia seriata, Grant in Edin. Plil. Journ. xiv. 116.

Hab. On the under surface of rocks in the Firth of Forth, D. Grant. Island of Ireland's Eye, off the Dublin coast, $\boldsymbol{V}^{\mathrm{T}} \mathrm{m}$. Thomipson, Esr.

Sponge crustaceous, spreading irregnlarly, homologous, of a fibro-reticular rather compact texture, scarcely friable when dry, inelastic: fecal orifices numerous, rather small, circular, arranged pretty regularly in rows over the even minutely porous surface: spicula short, slightly curved, more pointed at one end than at the other. Distinguished from H. incrustans by the regular close ranges of fecal orifices which traverse its flat surface, and which are never raised to the extremities of projecting papilla, as in the H. panicea. The spicula are similar to those of H. incrustans.

21. H.? CELATA, amorphons, yellow, imperfectly cellular, the surface bored with numerous circular oscula often filled with a mammillated pluy; spiculu shaped like a pin.

Var. $\alpha$. massive and rude.

ß. sinuous, the shape dependant on the form of the holes in old oystor-shells which the sponge occupies and fills.

C'liona celata, Grant in Edin. New. Phil. Journ. i. 78: ii. 183, pl. 2, fig. 7, (the spiculum.) Flem. Brit. Anim. 516. Stark, Elem. ii. 421. Johns. Brit. Zooph. 305, pl. 42, fig. 5, 6. Dujardin in Ann. des Sc. Nat. 1. s. x. 5 .

La Clione caclée, Blaine. Actinolog. 527, pl. 94, fig. 7. (The spiculum copiol from Grant.) 
$H a b$. ( ${ }_{\text {.) }}$ Dredged in eighteen fathoms water in the middle of Butribuy bay, near lioundstone: it occurred in abundance, $W m$. H. Colla. (3.) In perforations of the shell of the oyster, (Ostrea edulis) : abundantly in the oyster beds at Prestonpans, off Inchkeith, and in the roads of the Firth of Forth, Grant. Plymouth harbour, J. C. Bellamy.

This sponge, without beauty or definite form, occurs in hard earthy masses from two to four inches in diameter and an inch in thickness, when dried of a dirty brown colour, hard and incompressible, with an irregular uneven surface. The interior is yellow, imperfectly cellular, friable and stuffed with shells, the tubes of testaceous worms and gravel. The mass is drilled with short canals which open without order on the surface in the form of circular holes, having more the appearance of perforations made by worms than of the ordinary oscula. These are sometimes open and empty, but more commonly they are filled with a spongy mass that plugs up the aperture, forming a small obtuse papilla in it. From the worm-eaten appearance of the sponge one is tempted to believe that Montagu may have had specimens of it in view when he drew up the description of his Spongia fara; and specimens of the two species are sometimes much alike. Our most perfect specimens were sent from Ireland by $\mathrm{Mr} \cdot \mathrm{Wm}$. M Colla, who says that in a fresh state it is of a yellow colour, and that the perforations were then raised tubercles. He adds, that the species seems to be very destructive to the shells that come within its reach; and in several instances he had found large specimens of the Pecten opercularis killed by the encroachments of this parasite.

Having sent some morsels of a specimen to Mr Bowerbank, he favoured me with the figures of the spicula from which our woodcut has been made. " The rounded terminations or bases," he observes, "are very singular, the thick part not being quite at the eud in all cases. The hollow in the bulb is not always 
visible, and the central tube very rarely so comparatively. Of the forms, No. 1 is about the most common and 4 the most uncommon : the others are of frequent occurrence."

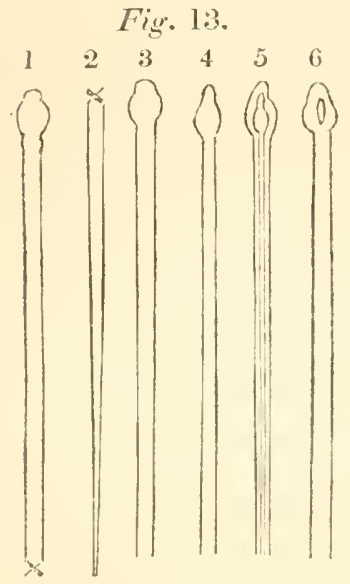

When this zoophyte inhabits and fills up the worm-like holes in old oyster-shells its form is modified and then " depends on that of the eavities which it fills; it insinuates itself into their mimutest ramifications, and adheres so closely to their smooth parietes, that it eannot be separated without tearing." The part which projects beyond the orifice of the hole is papillary. about a line in height and about the same in brealth, of a yellowish colour, tubular, and either closed or widely open at the apex. In texture, and in the morle in which the spicula are disposed amid the parenchyma, this production resembles Malichondria panicea or H. incrustans. It oceupes " the perforated shells of the living oyster, as well as the detached valves of the clead animal; but, in the living oyster, as the perforations are only seen on the ontside, and never pass through the innermost layer, there is always a thin layer of shell between the yellow substance and the living aninals. On the death of 
the oyster, and separation of its valves, the inner layer soon becomes likewise perforated, and the yellow matter is then seen projecting through the holes on both sides of the shell at the same time. By removing snccessively the outer layers, we easily discorer that the internal exearations communicate freely with each other, and with the apertures on the surface, and that all the pulpy matter which fills them, and projects through the superficial openings, is connected within so as to form one contimuous fleshy mass pervading the whole shell."-Grant.

Dr Grant has given an interesting history of this production, which he says is distinctly irritable, polypiferous, and oviparous. "During the months of March and April, when these observations were made," says this distinguished zoologist, " numerous small yellow ova were seen in the vicinity of the canals, agreeing much in their form, colour, size, and mode of distribution with those of the Spongia papillaris and Spongia panicea, which were then nearly in the same stage of advancement. The projecting tubular papillæ possess a complicated structure, and a high degree of contractile power, and exhibit a singular series of appearances, when the zoophyte is attentively examined while at rest in pure sea-water. When under water, the papillae are seen projecting from the apertures of the shell, sometimes to the length of a line and a-half ; they present a wide circular opening in their centre, and a rapid current of water issues constantly from them, conveying occasional flocculi of a grey membranaceous matter. But on being touched with a needle, or withdrawn from the water, the opening gradually closes, the current ceases, and the whole papilla continuing slowly to contract, is withdrawn completely within the aperture of the shell. The papillæ, viewed in their contracted state, present a smooth, rounded short extremity; but when they begin to advance beyond the surface of the shell, their extremity becomes flat and sightly dilated. assumes a villous appearance, with open fissures, 
radiating from the centre to the margin of the papillæ, and at length a minute circular opening is perceived in the centre of the villous surface. The papilla advances from the shell, and its central opening enlarges in proportion to the healthy state of the zoophyte, and the purity and stillness of the water ; its flat downy radiated surface gradually diminishes by the widening of the central opening, till only thin margins are left around the orifice, and the current is again seen to play briskly from it. In recent specimens of the Cliona dredged from an oyster-bed near the shore at Prestonpans, I examined under the most favourable circumstances on the coast, I have twice observed polypi of extraordinary minuteness and delicacy placed around the margin of the orifice, and which, kept in constant motion, advancing and withdrawing themselves into the substance of the papilla, while the current flowed from its central opening. The polypi were perfectly invisible to the naked eye in an ordinary light and position; but by suspending the Cliona in a crystal jar with clean water, and placing it between the eye and a candle, or the sun, they were scen like filaments of silk or asbestus constantly rising and sinking on the margin of the papilla. On cutting off a papilla, and placing it under a microscope in sca water, the polypi continued their motions, and were seen to consist of a long, slender, transparent, cylindrical, tubular fleshy body, at the farther extremity of which were placed about eight short broad tentacula, slightly dilated at their free ends, which were constantly inflecting and extending themselves irregularly while the polypi advaneed or retreated. In two entire and fresh specimens, the polypi continued visible and in motion for more than twenty-four hours in a jar of water at Prestonpans; but I have not yet succecded in perceiving them in any of the numerous specimens which I have preserved alive in the water procured from Newhaven."

Notwithstanding this circumstantial history, the accuracy of 
which I do not question, the examination I had made some time since of the Cliona induced me to believe that it was a member of the genus Halichondria, and this suspicion became more confirmed after I had procured Mr M'Colla's specimens, for there can be no doubt whatever of the identity of the production in the two states described. On communicating this opinion to my friend Mr Edward Forbes, I learned that he had arrived at the same conclusion; and after an examination of some portions of a massive specimen, $\operatorname{Mr}$ Bowerbank also agrees with us. "The structure of the animal," Mr B. writes me, "is so much in accordance with that of many species of British Halichondriæ that I have examined, that I cannot conceive it to be any thing but a true sponge, and that Dr Grant has been deceived by some parasite into the belief of its having true polypes as part of its original structure. I cannot but think that it is more likely that the Doctor, with all his known accuracy, should be mistaken than that so wide and essential a difference should exist between Cliona and Halichondria as that one should have polypes and the other be totally without them; and the existence of polypes in my idea would lead us to imagine quite a different arrangement of the parts of the animal from that where it was never designed by nature that they should exist."

The conjecture that the polypes, evidently ascidian, observed by Dr Grant, may be parasitical is not improbable, for, on a perusal of his history, it may be remarked that, in the very many experiments made by him, they were seen twice only, and their organic connection with the spongious mass is not distinctly made out. The currents as described too resemble those of the other sponges but not those produced by polypes, for in the latter the current is generated in the circumfluent water and invariably flows inwards along one side of the tentacula while an outward current sets up the opposite side, and the water neither flows out of nor enters within the body. The distribution of the 
ova likewise would be quite abnormal, and without any parallel, among ascidian or hydroid polypes, while it agrees, as Dr Grant states, with that observed in the Halichondriæ, to which this production seems to be nearest allied. I willingly admit that these observations do not prove any error in Dr Grant's description, but there appears in what I have stated to be sufficient grounds for asking a re-examination of the subject, and directing attention to it in this place.*

22. H.? AUREA, " broad, flat, and slightly divided at the top."

Spongia aurea, Montagu in Wern. Mem. ii. 86. Flem. Brit. Anim. 526.

Tupha aurea, Gray, Brit. PI. i. 356.

Hab. Plentiful in the estuary of Kingsbridge, covering the stones at low water, Montagu.

"Two or three inches broad, and nearly two inches high, of an orange-yellow when fresh, fading to brown when dry. Sometimes its slight divisions are tubular, but this is of rare occurrence. It is not so much divided as Spongia prolifera of Ellis, or might be thonght a variety; but in this, the base is always broad and compact, and the summit is more ragged than branched ; it contains a great deal of animal gluten, which in drying, contracts and connects the small divisions." Montagu.

23. II. ACULEATA, crustaceous, imperfectly and coarsely cellular, friable when dried; spicula very long and needleshaped.

Plate XIII. Fig. 1-3.

Halichondria aculeata, Bean, MSS.

$H a b$. Coast near Scarborough, rare, $W$. Bean.

* The Spongia terebrans of M. Durernoy would appear to be nearly related to our species, but he places it in the genus Calcoponge of $\mathrm{M}$. De Blainville. See Microscopic Journal, i. p. 47. 
The only specimen I have seen, and from which our figure is derived, is in the rich collection of its discoverer. It forms a rude, cellular, brown mass, half-an inch in thickness, adhering to its site by a thin membranous basis and hirsute with greyish hairs, formed by the spicula projecting beyond the surface. These spicula are very long, straight or somewhat flexuose, and shaped like a needle. It is their great length and the circumstance of their protruding beyond the surface, which characterize the species.

24. H.? Conus, " with numerous short flattish divarications issuing from the sides."

Spongia Conus, Montagu in Wern. Mem. ii. 85, pl. 10. Flem. Brit. An. 526.

Tupha conica, Gray, Brit. Pl. i. 356.

Hab. "Coast of Devon, rare," Montagu.

"The divarications are irregular in size, shape, and situation, but they are usually compressed, short, and broadest at the end ; these sometimes originate from an irregular stalk, giving a little resemblance to an expanded fir cone: the texture is rather coarse, and the outside furnished with spicula or short bristles. When dry it becomes stiff and rather hard, owing to the large quantity of gelatinous flesh which is obvious amongst the fibres. Colour, when dry, of a dark yellowish brown." Montagu.

25. H. ? RIGIDA, " with obtuse, spreading, irregular, flattish divarications, arising from the same base; usually a short stalk."

Spongia rigida, Montagu in Wern. Mem. ii. 87, pl. 11. fig. 1, 2 Flem. Br. Anim. 526.

Tupha rigida, Gray, Br. Pl. i. 356.

Hab. Coast of Devon, rare, Montagu.

"This sponge is as coarse in texture as Spongia officinalis, and when fresh, is of an orange colour, which it partly retains if tolerably freed from the animal gluten : the divarications are 
irregular in size and shape, but usually originate from one base or stem. When dried, it becomes rigid, but less so when it has been exposed for some time on the sea-shore, or, by repeated irrigations, the animal gluten is decomposed and washed out. Height about an inch.

"What is conceived to be a small variety, has the divarications more numerous and distinct, spreading from a short pedicle. In this, the reticular fibres are greatly obliterated by the large quantity of gelatine retained, by the contraction of which, the fibres are connected, and the sponge is rendered hard and destitute of flexibility." Montagu.

26. H. PERLEvis, "form indeterminate, texture close, surface covered with obtuse papilla."

Spongia perlevis, Montagu in Wern. Mem, ii. 86. Flem. Brit. Anim. 526.

Tupha perlevis, Gray, Brit. Pl. i. 356.

Hab. Coast of Devon, rare, Montagu.

"In texture this sponge is somewhat similar to tomentosa; is equally light, but not so soft and crumbly, nor of so pale a colour ; when fresh it is yellow, becoming of a light brown when dry : on the surface are numerous obtuse papillæ, the eighth of an inch in length ; these are not tubular, but of the same texture as the rest of the sponge; some are clarated, others bifid or trifid, and compressed; sometimes a few moderate sized pores are scattered orer the surface, very visible to the naked eyc, being as large as if made by a common pin. A specimen of about two inches long and an inch broad, taken on the coast of Devon, appears to have been attached to a rock its whole length." Montagu.

27. H. SANGUINEA, encrusting, of a deep blood-red colour, compact; fecul orifices smull and scattered; sprevelu lomg, curved, pointed at one cnd. 


\section{Plate XIV. Fig. 3.}

Spongia sanguinea, Grant in Edin. New Phil. Journ. ii. 135 and 203, pl. 2, fig. 9 .

Halichondria sanguinea, Flem. Brit. Anim. 521.

Halispongia sanguinea, Blainv. Actinol. 532, pl. 94, fig. 9.

$H a b$. On the under surface of the sea-beaten rocks of Islay, Staffa, Iona, and, along with the Sp. nivea, at the entrance of the spar caves on the shores of skye, Grant. Torbay, Dr. Coldstreem. Dublin Bay, Lambay Island, W. Thompson, Esq. Brighton, A. H. Hassal. Holy Island, near the Coves, sparingly, G.J.

This remarkable species forms an undefined crust from oneeighth to half-an-inch in thickness, of a uniform deep-red colour, becoming bright orange-red when dried, of a close compact texture, being composed of innumerable crystalline spicula interwoven in a gelatinous membrane, inelastic, with a soft fleshy feel when wet; the surface even, minutely pitted or rugose, with small circular scattered fecal orifices, which scarcely rise above its plane.

"It spreads on the under surface of rocks to the extent sometimes of six inches in diameter, with a thickness of more than half-an-inch, and it has always the same deep-red colour. The general surface is flat; but, on minute examination, it is found to be covered with numerous small round elevations and depressions, and the fecal orifices, which are numerous and small, are always observed in the depressed parts. The pores are very minnte, aud appear like perforations made by needles of different sizes. This species feels very slimy when torn, and abounds nearly as much with parenchymatous matter as the Spongia panicea, to which it has a close affinity in its general form and habits. Its spicula are siliceous, rather long, curved, equally thick throughout, obtuse at one end and pointed at the other." Grant.

H. sanguinea occasionally occurs in amorphous masses of con- 
siderable size and thickness, with a very uneven or ragged surface. When dried these specimens are hard and unyielding, and have indeed some resemblance to the dried root of British rhubarb. By attention to their colour, for a tinge of their pristine red always remains, and to the size and shape of the spicula, we can in general refer these abnormal specimens to their true species.

*** Texture rery compact, not fibrous nor friable when dry._- Duræ sunt hæ, ideoque a Spongiarum bonitate degenerant." The species, in general, have been referred to the genus Alcronium, Lin.

28. H. COALITA, branched in an irregular distorted manner, the branches diffise, inosculating; texture compact, brittle; fecal orificcs small or none; spicula various in size, fusiform, more or less curved.

Plate XII. Fig. 1.

Spongia coalita, Mull. Zool. Dan. prod. 256. Zool. Dan. iii. 71, tab. 120. Turt. Gmel. iv. 662. Montagu in Wern. Mem. ii. 80. Bosc, Vers, iii. 177. Lam. Anim. s. Vert. ii. 382. 2de edit.ii. 572. Lamour. Cor. Flex. 80. Corall. 184. Parkins. Oryctol. 47. Grant in Edin. Phil. Journ. xiv. 118; and in Edin. New Phil. Journ ii. 123.

Tupha coalita, Gray, Brit. PI. i. 355.

Halichondria coalita, Flem. Br. Anim. 522. Bellamy's South Devol1, 268.

L'Haléponge coalescente, Blainv. Actinol. 532.

Spongia suberosa, Esper, Spoug. tab. 41.

Hab. "Grows on dead shells, or invests corallines, beyond low-water mark," Fleming. Coast of Devon, rare, Montagu. Frith of Forth, very common on the oyster-beds, Dr Grant. Inhabits deep water, and is washed ashore in abundance after storms, $D$, Coldstream. 
Sponge rooted at various points, homogeneous, diffused, much and irregularly branched, the branches distorted, anastomosing, roundish, or more or less compressed, and often subcarinated at the sides, where a few porous tubercles are sometimes observed: structure compact, friable and inelastic when dried, cellular internally, the surface somewhat pitted or rugose, but its pores are scarcely visible without a magnifier; colour grayish-white. Spicula very abundant and various in size, - the larger ones fusiform, and usually somewhat curved,-the slenderer ones linear, sharp-pointed, either straight, or varionsly bent. " In the $\mathrm{S}$. coalita, besides the slender-curved fusiform spiculum, we observe a long thick spiculum of the same form, which extends along the sides of two or three successive pores, and contributes much to their strength in a species peculiarly liable to have the diameter of those passages disturbed from the flexibility of its branches, * and their erect position at the bottom of the sea." Grant.

"When the coalita is young, its branches are long and slender; they shoot in all directions to seek for points of attachment, and adhere to, or envelope, everything they meet with, living or dead, animal, vegetable, or mineral ; wherever the branches cross or touch each other, they form a perfect union; sometimes the animal spreads as a layer over an oystershell, or covers a rock like a convoluted bush, or like the root of a fucus, or forms a cement; connecting into a mass all manner of shells, stones, or broken glass; sometimes it forms an irregular mass, with a perfectly smooth surface, without any point of attachment, rolling to and fro, at the mercy of the waves. As it advances in life, its colour assumes a darker shade, with a tinge of brown; it becomes less smooth on the

- In a dried state the branches are brittle; nor do they erer grow erect, in the proper sense of the word. 
surface; loses its translucency; and its fibrous part predominates, as the hard parts of other animals predominate progressively from birth to decay." Grant.

Dr Fleming has correctly remarked, that in substance this sponge resembles Halichondria panicea, but it is denser and less friable. It is undoubtedly the Spongice suberosa of Esper; and has no affinity with the $S p . L y c o p o d i u m$ of that author, as Lamarck and Lamouroux erroneously affirm. The latter is probably a variety of $\mathrm{H}$. cervicornis. Muller was the discoverer of the species before us, and his description is as follows: "Spongia pulchre flava, exsiceata alba evadit. Rami varie inplexi et confluentes, teretes passim compressi, inordinate crassi et tenuiores vel fucos obvestiunt, vel libere crescunt. $P u r i$ abs. que ordine passim conspicui, non prominuli. Substantia mollis fragilis. An Spongia oculata auctorum? obstat, quod nec tenax sit, nee pori promineant."

29. H. vingultosa, erect, forming an undivided roundish or slightly compressed branch of a hard compact medullary texture; pores invisible; fecul orifices scattered, level ; spicula linear with sharp ends.

\section{Plate XV. Fig. 1-3.}

Spongia virgultosa, Lam. Anim. s. Vert. ji. 375. 2de edit. ii. 565. Lamour. Cor. Flex. 66. Corall. 177. Parkins. Oryctol. 44.

Hab. Coast at Scarborough, Mr. Bean.

I have seen fragments only of this species from the collection of $\mathrm{Mr}$ Bean. These are simple rod-like branches, from 6 to 12 inches in length, about half an inch in diameter, or of the size of the little fiuger, somewhat compressed, more or less twisted, of a very compact pithy structure, and incompressible when dry: the surface smooth to the naked eye, but rugose 
under a common magnifier, more or less uneven, without pores, of a grayish-white colour ; the fecal orifices scattered, small, slightly raised, closed in dry specimens, and duskier than the rest of the surface: intemally not properly cellular, but permeated by winding canals : spicula siliceous, crystalline, slender and linear, with sharp ends, but of very unequal lengths and size, and either straight or curved.

The substance of this sponge is similar to that of H. ficus. It answers so exactly to Lamarck's definition of Spongia virgultosa, excepting in being unbranched, that I cannot doubt its identity with the specimens before me, but the figure of Esper, (Spong, tab. 66, ) to which he refers us for one of its varieties, is not only excessively branched, but is apparently more loosely porous than I have observed this to be.

30. H. IInsuTA, crustaccous, compact, granular, with an cven villous surface; no pores nor oscula; spicula needleshaped.

\section{Plate XVI. Fig. 1.}

Halichondria hirsuta, Flem. Brit. Anim. 522.

I/ab. On Escharæ from deep water : coast of Banff and Zetland, Fleming. Strangford Lough, encrusting a shell, $\boldsymbol{W} \boldsymbol{m}$. Thompson.

"Base, when dry, very thin, granular, with long singlepointed spicula, the surface hirsute with the projecting free extremities." Fleming.

Sponge crustaceous, spreading irregularly, from one to four or five lines in thickness, composed of a mass of closely compacted nearly equal granulations, of a uniform pale gall-stone yellow colour when recent, the surface even and villous, without pores or oscula: structure homologous, compact and firm, 
granular, not netted : spicula obtuse at one end, and tapered to a sharp point at the opposite one, rather short, but variable both in length and thickness.

The specimen from which our figure is taken owes its pearshape to the form of the piece of shell which it has entirely encrusted. I owe the opportunity of examining it to the attention of William Thompson, Esq. of Belfast, - a naturalist ever on the watch to contribute to other's whatever his zeal has collected together; and whose uncommon tact in the discrimination of species renders his aid and opinion especially valuable.

31. H. sUBEREA, chorusting dead mivalve shells; structure medullary, compact, the surfuce even, porous, withont fecal orifices; spicula fusiform and slightly curved.

\section{Plate XII. Fig. 5, 6.}

Spongia suberia, Montagu in Wern. Mem. ii. 100. Sp. suberosa, Gray's Br. Pl. 361.

Halichondria suberica, Flem. Brit. Anim. 522. Coldstream in Edin. New Phil. Journ. ix. 235, pl. 2, fig. 3-5. Thompson in Anı. Nat. Hist. v. 254. Bellamy's South Devon, 268.

Halispongia suberica, Blainv. Aetinol. 532.

Alcyonium bulbosum, Esper, Alcyon. p. 41, tab. 12, fig. 1-6.

Alcyonium tuberosum, Esper, Aleyon. tab. 13, fig. 1-6.

Alcyonium compactum, Lam. Anim. s. Vert. ii. 400 : 2d edit. ii. 606. Lamour. Cor. Flex. 354. Corall. 251. Parkins. Oryctol. 59 .

Hab. Not uncommon in the estuary of Kingsbridge, and is frequently taken by the dredgers on the coast of Devoushire, Montagu. At Scarborough, Mr. Bean. Rothesay Bay, Dr, Culdstream. Coldingham, Berwickshire, Mr Maclaren. "I have found this species encrusting corallines in the Frith of Forth," Dr Fleming. Ayrshire, Rev. D. Landsborough. Isle of Man, E. Forbes. Dredged in the loughs of Strangford 
and Belfast, Wm. Thompson. Dublin bay, A. H. Hassal.

"This sponge is of a corky nature, resembling the close texture of the stalk of some species of Boletus. It has rarely any other pores than what are formed by the fibres, which are so extremely fine as not to be risible to the naked eye, eren when broken ; and with the assistance of a pocket lens, they are not definable on the surface. Its colour is orange-yellow when fresh, becoming brown when dry : its shape is indefinite, but it has the singular property of being attached only (so far as I have been able to ascertain) to old univalve shells, which it entirely invests. It is also remarkable, that few instances occur, where the hermit-crab has not formed a lodgement in the nucleus shell, and there appears to be a great struggle between the two parasitical intruders, as the sponge is continually endeavouring to fill up the aperture of the shell, while the crab, by its occasional motion in search of prey, frustrates that natural propensity of the sponge. Notwithstanding the efforts of so active and restless an intruder, the gradual and insensible increase of the sponge gains upon the premises of the crab; it pushes it on all sides, and completely lines the interior surface of the shell, so that the crab soon finds its habitation too small, and is compelled to search for a more capacious home.

"The species of shell may frequently be traced which constitute the mucleus of this sponge. Buccinum reticulatum and undatum, Turbo terebra and littoreus, are frequently covered by this sponge, except more or less opening to the aperture of the shell.

"It is a curious circumstance that no instance has occurred where this sponge has been attached to a living shell, or such as were inhabited by its proper animal. Either the increase of the sponge must be very rapid, or its efforts to inclose the aperture of the shell, must be most successfully performed between 
the period of its being quitted by one inhabitant, and the possession of another ; for the Hermit-crab is continually changing its abode, in order to accommodate its cell to its growtl.

"In every instance where a crab has been found to inhabit such a shell, the sponge has invariably spread within the aperture, and frequently a considerable extension of the lip to the shell is produced by the sponge." - Montagu.

The shelly nucleus of this sponge will often be found, on a section of it, to have been more or less completely absorbed, as is obvious from the disappearance of some of the whorls, or the unusual thinness of their walls.

Fig. 14.

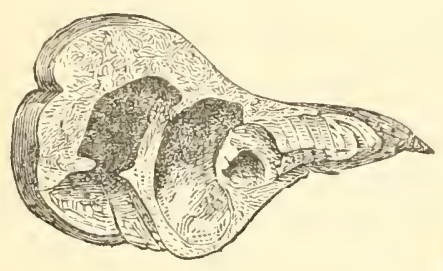

Whether this absorption of the shell has been effected by the Hermit-crab or by the sponge may be questioned, but the crab, in my opinion, is the agent, for shells inhabited by it, and free of sponge, have bcen found in a similar state of decay. "It is probable," says Mr J. E. Gray, " that some Bermard crabs have also the faculty of dissolving shell, for it is not unusual to find the long fusiform shells, such as Fusus, Fasciolaria, and Turbinella, which are inhabited by these animals, with the inner lip and great part of the pillar on the inside of the mouth destroyed, so as to render the aperture mueh larger than usual. I have never seen this erosion except in dead shells which had been inhabited by Hermit crabs; but it does not occur in all that are so tenanted, for I lave also observed these animals 
occupying the shells of Fusi, \&e. in which the lip was in its usual state."-Phil. Trans. an. 1833, p. 797.

Lamarck has quoted, though with doubt, the figures in Esper's Alcyon. pl. 12, for representations of his Alcyonium domuncula; and, with the mark of equal doubt, he has again quoted them for his Alcyomium compcetum. This confusion has been avoided by Lamouroux, who, perceiving that the figures in Esper's plates 12 and 13 represented the same species, has properly quoted them all for Al. compactum. The change of Esper's name was, however, very umnecessary, and perhaps the species should still be called Halichondria bulbosa, but I have preferred the English naturalist's nomenclature since it is free of doubt, and unencumbered with misquotations.

Mr. Thompson informs me that Jonston in his " Historia Naturalis," bk. 4, tab. xx. gives figures of this sponge, apparently copied from Aldrovandus. One of them shows a $\mathrm{Pa}$ gurus displaying itself from the aperture; and in two of the figures the point of a Turritella protruding discloses the shell that has been the base and nucleus of the sponge. It is mentioned also by Limnæus under his description of the Cancer Eremita :- " Habitat in M. Italico intra toplum suberosum, subrotundum apertura transversa orali, in cujus centro cochlea latitat." Syst. 1050.

32. H. MAMnILLARIS, amorphous and compact, the surface studded with erect flexible spongy tubular processes ; spicula fusiform, acute at both ends.

\section{Plate XVI. Fig. 2.}

Spongia mammillaris, Mull. Zool. Dan. iv. 44, tab. clviii. fig. 3, 4. Lamour. Cor. Flex. 59. Corall. 173. Thompson in Amm. Nat. Hist. v. 254.

Spongia Penicillus, Montagu in Wern. Mem. ii. 93, pl. 13, fig. 7. Flem. Brit. Anim. 526. Templeton in Mag. Nat. Hist. ix. 471. 
Spongia mammifferis. Parkinson's Oryctology, 43 .

Spongia Imperati, D. Chiaie, Anim. s. Vert. Nap. iii. 114, tay. 37, fig. 18 and 23.

Tethya? penicilliformis, Gray, Brit. Pl. i. 362.

Hab. "Coast of Devon, very rare, Montagu. Found on Robin Hood's bay sands (Searborough) after a serere storm," W. Bean. "Fourid on the rocks at White Honse Point ; July 1811," Templeton. "A specimen of this sponge was dredged in Strangford lough in 1835, by Mr. Hyndman and myself," Wm. Thompson.

Sponge sessile, amorphous, compact, the surface proliferous of numerous long tubular flexile processes: base crustaceous, thick, withont any pores, villous or sericeous when recent, rather soft and yellowish, but after being dried white, firm and incompressible: the processes slender, from a few lines to fully an inch in height, compressed, slightly tapered, transparent and delicately reticulated, open at the extremity, which is plain and round. The spicula are long and straight, fusiform, sharp at both ends. In the basal portion they are very numerous and arranged in bundles; but in the processes they are less abundant, and the areolar appearance of the surface is produced by many of them being disposed crosswise.

"The interior substance of this species," says Montagu, " is precisely that of [Tethea] Lyncurium, but instead of being orbicular, it spreads horizontally upon marine bodies, and shoots upwards from its surface eylindric tubes of nearly an inch in length, which have an opening at the apex: these tubes are distant; and not disposed in regular order, nor of any determinate size; but on the same specimen may be observed tubes from the eighth of an inch upwards, in all gradations, to the length before-mentioned. In drying, the tubes become compressed and a little areuated, and all incline the same way; 
they are flexible, tough, and the texture extremely fine. The spiculæ that support the fleshy part, appear to be the base or continuation of the tubes; perhaps these are ligaments, and may contribute to give some small action to the tubes by inclining them to either side, or by expansion and contraction. When first scparated from the rocks, the asbestine-like spiculæ are not so obvious as when the flesh is contracted by drying. In its general appearance, this sponge bears some resemblance to Lichen filiformis.-The only specimen was taken by dredging, and is an inch and a-half in length."

The figure in Zoologia Danica is less characteristic than Rathke's short description : "Hæmisphærica erat cava e griseo flavescens, lapidi innascens tubulis conico flexuosis in superficie eminentibus, inæqualibus; textura stuposa et fragilis est fibris brevibus."

"A flint stone, found on the shore at Dawlish in Devonshire, bears decided marks of having derived its form from the siliceous impregnation of Sp. mammillaris." - Parkinson's Oryctology, p. 51 .

33. H. FICUs, bulbous, or pear-shaped, very compact, the surface even and smooth; oscula few, scattered, closed uhen dry, often obsolete : spicula needle-shaped.

Plate XV. Fig. 4 and 5.

Alcionio tuberoso in forma di fico, Imperat. Ital. 641, fig. inf.

Sponge called the Sea-Fig. Ellis and Soland. Zooph. 206, pl. 59, fig. 4 .

Alcyonium Ficus, Esper, Alcyon, tab. 20, fig. 1-4.

Alcyonium ficiforme, Lam. Anim. s. Vert. ii. 394 : 2 de edit. ii. 599.

$H a b$. In deep water at Scarborough, rare, $M r$ Bean. "In the summer of 1823 , having procured many specimens of Den- 
talium entalis with their animals alive, from a fisherman at Hartlepool, who dredged them up in his trawling-net from very deep water, I observed a kind of sponge which has, I believe, been confounded with the Alcyonium Ficus, Lin." J. Hogg. Coast off the Iste of Man, E. Forbes.

Sponge obovate or pear-shaped, sometimes bulging from a narrow stalk, from one to fully three inches in height, and one inch and a-half in diameter, either bulbous or compressed laterally, very compact, firm, incompressible and inelastic, of a greyish-white colour, the surface smooth, either punctured or without visible pores, and without fecal orifices, or these are very few, small and scattered. The texture of the interior is likewise very close and compact, and exhibits a very imperfect cellulosity, but it is permeated with some short and narrow canals that have no certain distribution, and do not reach the surface.

H. Ficus may be compared, and in general aptly, to a halfripe Puff-ball, (Lycoperdon), but the sponge, is of a less yielding and denser texture. It is composed of acicular siliceous spicula matted together and crossed in every direction amid the gelatinous parenchyma which forms the basis and agglutinating medium. These spicula are very slender and rather long, varying extremely, however, in their degree of slenderness, and while some are straight, others are curved, and others are flexuose: They are more pointed at one end than at the other, but, from their brittleness, entire spicula are with difficulty obtainable. Mine-Edwards says, when speaking as I think of the same species, that the parenchyma which surrounds then contains some carbonate of lime. I found that dilute muriatic acid rendered the surface of the sponge a shade whiter; and on immersing a piece of the interior in the acil a scarcely perceptible and evanescent effervescence was produced; but I an satisfied 
that the calcareous particles must have been extrinsic and foreign to the sponge.

The figure of II. Ficus is liable to some modification from the nature of the olject it grows npon. If this has an even broad surface, like a bivalve shell, the sponge fixes itself with a spreading crustaceous base and rises up on a thick strong neck; but if the shell is univalve and cylindrieal, then the base of the sponge is limited, and the neck slender and pedicellate, supporting a heary bulbous head, such as it is represented by Esper, of whose figure I have given a copy at page 77. Esper's specimen grew from a Turritella, and $\mathrm{Mr}$ Hogg found the sponge assuming precisely the same form when it had attached itself to the Dentalium.

H. Ficus has no relation to the Alcyonium Ficus of Pallas, or Alcyon. pulmonarice of Ellis, which is one of the compound tunicated Mollusea.

34. H. Carvosi, fig-shaped, compact and fleshy, the surfuce smooth and even; interioryellowish; spiculu with a butbous heul, tupered to a sharp point.

\section{Plate XIII, Fig. 7, 8.}

Hab. Roundstone bay, Cumnamara, $\mathrm{H} \cdot \mathrm{W} \cdot \mathrm{m}$. $\mathrm{H} \cdot \mathrm{Colla}$.

Sponge irregularly ovate, as large as a plum, fleshy and very compact, of an olivaccous colour after being preserved in spirits, the surface even and very smooth, muporous, and with only one or two imperfectly formed oscula on the sides. The interior is solid, fleshy and homogeneous, tinted with yellow, and permeated with slender sinuous canals, which do not penetrate the thin skin. The spicula are minute and lie principally in parallel faseicles in the animal matrix : they are pretty uniform in size and form, and, when entire, have a bulbous head like a pin, whence 
they taper to a sharp point at the opposite extremity. They are more $0^{*}$ less curved and very brittle, so that the head is either often broken away or awanting, when that end appears to be simply obtuse and rounded. The animal matter consists of a vast number of pellucid granules connected by a sort of mueilage. When dried the sponge assumes a silky appearance from the projection of the points of the spicula beyond the surface.

In habit and compactness of texture this sponge is a Tethea, and, like the species of that genus, it is also covered with a distinct skin, but the disposition of the spieula is different, and there is no central nuclens.

35. H. serosa, flattened, sessile, erect, expanded laterally, of a very compact fleshy texture with a smooth unporous surface; spicula needleshaped.

\section{Plate XVI, Fig. 3, 4.}

Hab. Shores of the Isle of Man, Edu. Forbes.

Sponge sessile, undivided, forming a much compressed erest or lamina of a close compact suety texture, semitransparent, appearing when held between the eye and the light somewhat pitted with paler scattered spots, the surface uneven, rivose, smooth, without any pores or fecal orifiees.

The only specimen of this singular sponge $I$ have seen is about three inches in breadth, one in height, and about the eighth of an inch in thickness. It has small resemblance to a sponge, and would have been considered an Alcyonium by Lamarck. It may be compared to a portion of the fatty caul of a sheep, or to a piece of suet moulded to its shapo by pressurc. Like the II. Ficus it consists almost entirely of siliceons, rather long needleshaped spicula, eompacted and crossed in every direction, and held together by a gelatinous membrane. The surface of a 
dried specimen is sericcous from the projection of the points of the spicula.

Fig. 15.

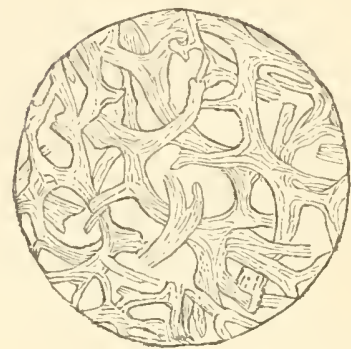

H. PALIATA: stucture of.

"At vero quaita maris est pulchritudo? Quæ species universi? quæ multitudo et varietas insularum? Quæ amœnitates orarum et litorum? quot genera, quamque disparia partim submersarum, partim fluitantium et innantium belluarum, partim ad saxa nativis testis inbrentium." Cic. de Nat. Deorum, lib. ii, c. 39. 
3. SPONGILLA, Lamarek.

Spongix pars, Lin. Syst. 1299.—Tupha, Oken in Schweig. Handb. 421.—Ephydatia, Lanour. Cor. Flex. 2. Gray, Brit. Pl. i, 353._- Spongilla, Las. Anim. s. Tert. ii, 98: 2de edit. ii. 111. Blatsv. Man. 533, and 6 83 . Scuweig. Mandb. 421. —-Badiaga, Bexbaum in Spreng. Syst. I'eg. iv, 374._- Halichondrixe pars, Flem. Brit. Anim. 524.

Character. Sponge homologous, polymorphouts, latticed and imperfectly cellutar, the cells bounded by unequal fibres composed of siliceous spicula laid in a translucid gelatine; interstices filled with an organic granuliferous mucus; spicula acicular, simple; pores and oscule ill defined: oriform capsules or sphcerula are generatcd at certain seasons in the cells.-Colour a shade of yreen.-Lacustrine or fuciatile.

TIIE Spongilla, says Dr Crant, " is a fresh-water production, of al green or grey colour, soft, fibrons, reticulate, friable texture, irregular flat spreating form, and strong fotid odour; it contains a turbid green-coloured gelatinous-like matter in its interstices, and erect branched fibres pass throngh its interior, arising from its base, and projecting from its surface."

The fibres consist of mimute siliceons spicula laid usually in parallel fascicles and held iogether by the organic gelatine. 
These spicula have apparently no constant or ordinate arrangement, but, according to Dr Grant, they are "placed like a frame-work round all the openings, in the order best calculated to prevent these passages from changing their dimensions." They are all of the same form and mostly of one size, linear, very slightly and regularly curved and acutely pointed at both ends. Dr Grant describes them as being cylindrical and tubular, and such they have appeared to be to us, but Raspail says that they constitute solid six-sided prisms. "If these bodies were tubular," he adds, " it is evident that when placed in water after having been broken in the air, their median line wonld be black instead of white, on account of the difference of the refractive powers of its internal capacity; but this illusion is destroyed by simply cutting the crystal across somewhat obliquely, in which case a dark and homogeneous base is presented." New System of Organic Chemistry, p. 543-4, pl. 12, fig. 1-5.

The soft gelatinous matter which fills the interstices of the sponge consists of a colourless glairy fluid, filled with minute transparent gramules. Where this matter lines the canals or surface, and where it is exposed to the friction of the circumfiuent water, it is protected by a delicate and diaphanous pellicle or skin.* The gramules lie underneath, but at certain seasons, either from the expulsive appetency of maturity, or from the decay of portions of the common mass, they are separated from it, and are the means of diffusing and continuing the species. When first set free from their gelatinous soluble matrix they are endowed with a distinct power of locomotion, and in liveliness and mobility rival the infusorian animalcules, with which

* This skin is particularly described by Dutrochet and Hogg. Dr Grant says,_- "The soft matter of the Spongilla does not seem to possess a distinct membranous coat, but is a little more consistent, and has a glistening surface, wherever it is in contact with the element in which it lives, as within the caulals, and on the outer surfice of the borly." 
they may be readily confounded. "These bodies," says Mr J. Hogg, " are very minnte, though some are less than others, and are plainly visible to the naked eye ; they are white, of a somewhat globular, or rather, more oval shape, the lower or smaller portion being opake, and the upper transparent and membran-. ous. Their movements in swimming were no less astonishing than elegant; ascending from the sponge at the bottom of the water to the surface; floating gently on the surface; or traversing the middle of the fluid, like a balloon in the air ; or suspending themselves nearly in one spot; or whirling round and round, describing larger or smaller cireles in the water; approaching or avoiding each other; but, when performing their quicker progressions, they move along on their sides with their rounder ends precedent."

Since the surface of these seminal granules is not ciliated, but naked and smooth, it seems probable that their motility is dependant on the action of endosmose. The power to move about continues in them no longer than is necessary for their separation from the parent mass, ceasing after the lapse of at most one or two days. Having become fixed, the granules first lose their spherical form, and begin to spread over their site as a thin transparent film. There are at first no spicula, but they soon make their appearance, originating from no fixed point, nor evolved in any certain order, but in rapid succession, and, what is remarkable, they lrave the same figure and size in this primordial spot as they have in the adult sponge. "The orum," according to Dr Grant, " in spreading, changes its circular form for an oblong or irregular outline, but its spreading margins are always surrounded with a very thin homogeneous film, while its granular bodies and spicula occupy chicfly the convax middle part. I have observed, however, spicula quite isolited make their appearance in the spreading mareciual film. None of the spicula are erer uhserved to shoot their points maturally 
through the surface, or beyond the margin of the ovum; alt'longh the slight agitation of changing its water from time to time, soon causes many of them, already formed within the ovum, to project beyond its surface. This renders it probable that all the spicula, even the naked gromps, projecting round the pores and orifices, were originally formed within the surface of the soft matter. Analogy leaves no doubt, that these ova or spherical portions of gelatinous matter, when ready to separate from the parictes of the canals, are delivered by the currents through the large fecal orifices as in the marine sponges; but I have not detected any cilia on their surface, nor seen them swim about by their own spontaneous motions, like many marine ova, before fixing themselves. The ova were nourished only with rain watcr, while the spicula were successively forming in their interior; which shows that these simple gelatinous globules, in which neither vessel nor fibre are discernible, have the power of secreting siliceous tubes from that pure element." Grent.

The Sphrrulæ are produced only under favourable circumstances. Although the Spongilla is not uneommon in the waters of Berwickshire, yet a specimen with these bodies has never occurred to us. When they do exist they are usually in great abundance, lying dispersed without order through the mass of the sponge, and attached rather loosely to its fibres.* "I have frequently," says Dr. Grant, " found a portion of spongilla crowded with them, while another growing beside it contained none; and even the same portion sometimes presents them

* "They are distributed very irregularly, but abound most in the deeper parts, where they frequently lie looscly collected in groups of about twenty or thirty ; they lave no perceptible organic conncetion with each other, or with the substance in which they are imbedded." Grant. According to Link, eacb sporangium or sphierula occupies a single cell, to which it is exactly adjusted. Ann. des. Sc. Nat. Part. Bot. n, s. ii. p. 328 . 
crowded in one place, while they are entirely wanting in another." They are abont the size of turnip-seed, of a globular shape and yellowish colour, with a rough external surface, but which is not ciliated, neither have they any power of locomotion.** They are composed $1^{\circ}$. of contained globules essentially similar to the gelatinous granules already described; and $2^{\circ}$. of an elastic cartilaginous envelope which, according to M. Gervais, consists of two layers, - an inner one, which is firm and reddish, and an outer one, which is tomentose and tinted with a gilded yellow. There may be observed on most of the sphærulæ, a spot to which attention was first called by Link and Raspail. They considered it to be a hitum, but Gervais is of opinion that it cannot be so, because the sphærula has no pedicle or funiculum, lying loose amidst the green globules, and because this pretended hilum is sometimes multiplicate, viz. it is sometimes douhle, and still oftener triple or quadruple. The spot in question has usually the reddish colour of the inner envelope, for it is in fact formed by a portion of this becoming visible in consequence of the partial obliteration of the external tunic. It is at this spot that the contamed globules burst through, and ifter they have escaped, there remains a very perceptible hole. While still enclosed in the sphærula the globules lie sometimes scattered confusedly in the interior, but occasionally they are united in little roundish masses without any peculiar envelope. In some

* “Autumnali tempore in luujus poris sparsis globulos cáculescentes magnitudine seminum thymi, nitidos in flamma eandelæ fulgurantes observarit C. Blom. W. D. an corpora peregrina ?" Lin. Syst. 1299._-lı "letter to Ellis, Linumus thus describes the same bodies:- "There is lately come to my hands, from one of our Sweedish lakes, a most beantiful Spongia, though in a dried state, in which I can distinctly sce some animalenla in their transparent vesicles. The branches of this Spongia, when brought to the flume of a eandle, take fire with a briglit effulgence, and the animalcules explode in little fiery globules of a very lively blue." Li1. Corresp. i. p. 183. 
cases it happens, however, that while even within the sphærula the globules give origin to the formation of other sphærulæ, just as they do when expelled from it. Thus Gervais has found beneath the bases of some masses of Spongillæ a great number of these parent sphærulæ, which themselves contained two, three, or even four others, having the same structure, the same composition, and the same yellowish colour.**

There appears reason to beliere that the contained globules are essentially the same as the gelatinous granules of the organic mueus. The observations of Professor Grant are, it is true, opposed to this conclusion, for his description of the contained globules differs from that which he has given of the granules ; $†$ nor did he find that either they or the entire sporidia suffered any change, or showed any sign of germinating, during the six weeks they

* According to Meyen these sphærulæ, sporidia or sporangia (for all these terms are applied to them) of Spongilla are essentially distinct from the sporangia of Algre, and are similar to what are denominated the winter eggs of polypes. "They consist of a coriaceous skin, which is covered over with a thick crust, except at a small circular spot. This crust is composed of minute and delicate siliceous particles of the 3-50th of a millimetre in length, which particles are composed of vertically placed spicula of 1-250 to 1-200th of a Mm. broad, at whose extremities near the circumference, more or less toothed, little disks are found. At an after period from $4-5$, or more generally $7-8$ of the teeth elongate, becoming uncinate and curved rays. Between the spicula exists carbonate of lime, having a cellular structure. Within the eggs are delicate cells filled with various granular matters. Besides the larger siliceous spicula found within the substance of the sponge, there exists more delicate ones of the 1-16th to 1-10th of a Mm. long, having upon their surface numerous little points, which elongate as their age increases." Microscopic Journal, i. p. 42.

$\uparrow$ He deseribes them as gelatirous globules, each containing "abont a hundred very small white opake particles, which lie close together on one side of the globule, and ocenpy about a third of its capacity." The gelatinous portion is soluble, but the white particles suffered no change, "though they seem to possess the power of slowly changing their positions." 
were kept under observation, although the true ova of the Spongilla, in the same vessel, were growing and spreading vigorously. But the subsequent experiments of Dutrochet, Gervais, and Mr. John Hogg, leave no doubt of the truly seminal character of the sphærulæ,- their granular contents contributing to the increase of the original mass when they are shed in it, and when retained until the sphærula has been separated by decomposition or maturity, they then give origin to new individuals. The progress of their developement has been well described by my friend Mr Hogg. "Having taken," he says, "many of these fresh seed-like bodies from their fixed localities in the cells or pores of the sponge, I deposited them in a china dish nearly filled with water, which I renewed twice a-day. I was most attentive in examining, not only with my naked eye, but also with a powerful lens, whether these bodies possessed any spontaneons motions, but could not discover the least appearance of any ; on the contrary, the instant they were put into the water they sumk to the bottom of the dish ; there remaining motiouless, most of them commenced to germinate, and became permanently fixed. Sereral of these seed-like bodies being of difierent sizes, I found that some began to grow sooner than others, probably by rea.. son of their being in a more mature state. The manner of germination, according to my observation, is this: when the seedlike body has lain a sufficient time in the water, a very small quantity of a soft opake substance appears spontaneously protruding from its apex or orifice at its top; it is of a pure white colour, and soon glues the seed-lilie borly to the dish; this substance gradually increases, and sometimes cutirely enveloping the parent body, continues spreading orer whatever object it has attached itself to. At first there are 10 distinct traces of the sponge itself, but only a white thick gelatinous matter, like al piece of wet cotton wool, is all that is to be seen : this, howerer, when allowed to dry, will exhibit the thin mentrane of the 
sponge, and the oseules and cells or pores formed by the interlacing and crossing of the young fibres with the sharp and prominent spicula. As a few of these bodies, after several days, did not germinate, I squeezed them sufficiently hard, so as to break their enrelopes or shells, and pressed out a little of the inmer opake substance, which then very readily grew and enlarged." *

The various opinions entertained by naturalists relative to the nature of Spongilla have been already mentioned. $\downarrow$ Mr Hogg is the latest and most strenuous adrocate of its regetability. From numerous observations and experiments, made with care and under favomable circumstances, he found that the intensity of the greenness of the Spongilla depends upon its more or less direct exposure to the light, for specimens were alternately blanched and greened by turning down the surface of the stone on which they grew, and, after a due season, reversing its position.f Now, as light has exactly the same effect on plants, and is not known to have any similar influence on the colour of animals, the experiments afford a strong presumption that this production is more nearly allied to the alga or fungi than to any member of the animal kingdom, and $\mathrm{Mr}$ Hogg strengthened this inference by other facts. He found, for example, that the

* See some recent observations by Laurent on the reproductive organs of Spongilla in the Microscopie Journal, i. p. 78.

$\dagger$ In addition to those names of naturalists who adrocated the vegetable nature of sponges, especially of the Spongilla, those of Blumenbach (Elem. Nat. Hist. Trans. p. 271), and De La Pylaye slould be added. The latter confounded the Cristatellae with Spongilla. Bull. des Sciences Nat. xvii. p. 99.

\& Lamouroux ascribed the variable colour of the Spongilla to the nature of the sites from which it grew : Bory St Vincent to the presence of the Anabuina impalpabilis. " S' introduit dans l'Eponge d'eau douce, et lui donne dans certains endroits cette coulcur verte, qu'elle n'a point quand l'Anabaine ne croit pas dans son voisinage." Ency. Method, Zoologie. For this reference I am indebted to my frieud, William Thompson, Esq. 
diaphanous pellicle which invests the soft jelly of the sponge and its canals had a general resemblance to the cuticle of the leaves of many of our common plants; while the jelly itself is very similar to their parenchymatous substance, composed as it is of numerous pellucid globules. It was ascertained also that the green colouring matter or "chromule" contained in these globules, on being pressed out, gave a permanent green or yellowish-green colour to white paper, not to be distinguished from the stains produced by the chromule of leaves and plants; and strong acids had the same effects on the sponge as they are seen to have upon plants macerated in them. Add to these correspondencies the fact that numerous bubbles of gas, most probably oxygen, are disengaged from the surface of the living mass of Spongilla, when exposed to the brightest solar light, just as is known to occur with the leaves of a plant when immersed in water and submitted to the direet action of the light of the sum, and we have seemingly a series of proofs which, in the absence of any trace of animal organization or property, almost demenstrate its sameness with the products of regetable life.

In whatever way this question may be settled, it is now indisputable that the verdict affects the position and rank, not of the Spongilla alone, but of the whole family of sponges; and there are facts which this wider range of the enquiry brings before us, that makes us hesitate to accept the proofs of Mr Hogg as ralid and completc. The anomalous circulation through the sponge is one of these facts, for its existence in every speeies, and the sameness of its phenomena in all, are surely incompatible with the explanation of it which Mr Mogg has given. After many careful experiments, my friend asserts that he has never heen able to witness these currents in any specimen of Spongilla which has been entirely destitute of every parasitical insect or other animal ; and he has therefore conchded that the currents are caused by some insect, (usually by the anomalous 
insect which Mr. Westwood has dennominated the Branchiostoma Spongillæ, $\left.{ }^{*}\right)$ or crustacean or mollusean. Nearly every specimen of Spongilla is indeed a rich nestling place for one or more species of these classes, but thence to conclude that it is by means of their respiration that the currents which enter into and flow out from the pores and oscules of the sponge are generated and kept alive, is at variance with the previous observations of Grant† and Dutrochet. Nor does the eanse assigned seem adequate to the cxplanation of the phenomena, which are very different from those presented by the intermitting currents occasioned by the breathing of any animal I have observed; and it is difficult to believe that a current which is uniform and continuous, and always directed in one course, can depend on any cause which, like the action of breathing, must vary every moment in intensity, quickness, and in position, by the motions and actions of the animals.

The structure of the fresh-water sponges is so like that of the Halichondriæ, that Dr Flenning has deemed their separation unnecessary, but the systematists who have done otherwise are justified in their views by the looser texture of the Spongilla, its green colour, the cxistence of the seminiferous capsules at seasons in the cells, and the peculiarity of its habitat. Oken appears first of all to have proposed this separation, but the name which he conferred on the genus, as well as that subsequently given to it by Lamouroux, has yielded to the superior influence

* For notices of this animal see Athenæum for 1838, p. 899; Charlesworth's Mag. Nat. Hist. iii. p. 200 ; Ann. and Mag. Nat. Hist. vi. p. 315 ; Lin. Trans. xviii. p. 390.

$\dagger$ " The whole arrangement of the spicula, around the canals, shows that these are not accidental passages, formed by worms or aquatic in. sects in a vegetable substance, and helps to prove that its currents are not produced by any forcign intruders, though this substance is infested with myiads of ciliated animalcules, which are corstantly producing currents to attack their prey."-Grant. 
of Lamarek's nomenclature, which has received so general an assent that we have felt constrained to adopt it also, although the claim of priority is thus infringed upon.

1. Sp. Fuuviaturs, "soft, Irittle, and slenderly fibroms when dry ;" spiculu slightly curved, linear and sharp pointerl at both ends.

\section{Plates XVII. and XVIII.}

Spongia fluviatilis, Pall. Elench. 38t. Lin. Syst. 1299. Berk. Syn. i. 213. Turt. Gmel. iv. 662. Blumenb. Man. 272. Bosc Vers, iii. 178.

Badiaga fluviatilis, Spreng. Syst. Veg. iv. 374.

Ephydatia fluviatalis, Lamour. Cor. Flex. 6. Corall. 148.

Halichondria fluviatilis, Flem. Brit. Anim. 524.

Les Epouges d'eau douce, Gervais in Ann. des. Sc. Nat. 11. s. iv. 254.

Spongilla ou Eplonge d'eau douce, Dujardin in Amm. des. Sc. Natt. n. s. $x .4$, pl. i. fig. 1-4.

State $\alpha$. Sponge crustaceous, massive and slightly lober, or throwing up short branches. - Plate XVII.

Spongia fluviatilis anfractnosa, perfragilis, ramosissima nostras, Plunk. Plyytog, tab. 112, fig. 3.

Spongia fluviatilis ramosa fragilis, Raii, Hist. Pl. iii. 16. Syn. i. 30. no. 6 .

Fungus vel potius Spongia viridis, doliolis adnascenti similis, Raii, Syn. i. 57, no. 11 .

Spongia lacustris, Lin. Flor. Snec. 439, no. 1190. Fl. Lapp. 389. Syst. Nat. 1299. Esper, Spong. tab. 23 A, fig. 1-11. Berk. Syn. i. 213. Turt. Gmel. iv. 662. Turt. Brit. Faun. 209. Stew. Elem. ii. 435. Bosc Vers, iii. 178. Link in Ann. des. Se. Nat. v. s. Bot. ii. 328.

Spongia friabilis, Esper, Spong. tab. 62, fig. 1-4. Turt. Gmel. iv. 662. Bosc Vers, iii. 178.

Ephydatia lacustris, Lamour. Cor. Flex. 7. Corall. 149. Ephydatia friabilis, Lamour. Cor. Flex. 6. Corall. 148. Spongilla friabilis, Lam. Anim. s. Vert. ii. 100 : 2de edit. ii. 114. Risso, L'Europ. Merid. v. 36\%. Grant in Edin. Phil. Journ. xiv. 183 and 270 ; and in Edin. New. Pbil. Journ. ii. 138, pl. 2, fig. 1, (the spiculum), copied in Blainv. Atlas, pl. 94, fig. 1. Blainv. 
Man. 534. Schueig. Handb. 421. Templeton in Mag. Nat.

Hist. ix. $470 . \quad$ Stark, Elem. ii. 442.

Spongilla pulvinata, Lam. Aniin. s. Vert, ii. 99 : 2de edit. ii. 113.

Gray, Brit. Pl. j. 3 s3.

Spongilla fluviatilis, Blainv. Actinol. 534, pl. 92, fig. 6. Hogg's

Stockton, 39. Hogg in Ann. Nat. Hist. i. 478 ; ii. 370 : iii. 58 and

159 ; vi. $315.40 g g$ in Trans. Lis. Soc. xviii, 363 ; and in

Charleswortl's Mag. Nat. Hist. iv. 259.

Spongilla lacustris, Blainv. Actinol. 534.

State $\beta$. Erect and branched, plant-like. Plate xviii.

Spongia ramosa fluviatilis Newtoni, Raii, Hist. Pl. i, 81; Syn. i, 30 , no. 5 .

Spongia fluviatilis? Iin. Fl. Suec. 440 , no. 1191.

Spongiil lacustris, Esper, Spong. tab. 23, fig. 1, 2.

Spongia canalium, Turt. Gmel. jv. 662. Bose Vers, iii, 179.

Ephydatia canalium, Lamour. Cor. Flex. 6. Corall. 148. Fleming

in Edin. Phil. Jourı. ii, 88. Flem. Phil. Zool. ii, 614, pl. 5, fig. 4 .

Spongilla ramosa, Lam. Anim. s. Vert ii, 100 ; 2de edit. ii, 114.

Gray, Brit. Pl. i, 353. Dutrochet in "Ann. des Sc. Nat. Oct.

1828 , p. 205 ;" and in Bull. des Sc. Nat. xvii, 156. Stark,

Elem. ii, 442.

Spongilla canalium, Blainv. Actinolog. 534.

Spongilla lacustris, Schweig. Handb. 421 .

Spongilla pulvinata, Templeton in Mag. Nat. Hist. ix, 470.

Hab. On rocks and other solid bodies at the bottom of deep ponds, lakes and in still ruming waters, frequent, and found distributed very generally throughont the island.

When young this sponge "appears in small, round, convex spots of a light grey-coloured, soft, downy substance, adhering to the surface of stones under water, or spreading irregularly as a flat woolly covering of a light greenish-grey colour, having a line or two of thickness, and an extension of one or two inches. But as it advances in growth, it becomes more compact in texture, and of a darker sea-green colour, acquires a thickness of more than two inches, covers a continuous surface of several feet in length, sends up from every part of its surface irregular, 
short, compressed lobes, sharp ridges, thin laminæ, or cylindrical small branches rounded at their extremities, and it presents numerous very distinct apertures, of different sizes, leading into its interior. From the looseness of its porous surface and internal texture, and from its mode of enveloping substances in the progress of its growth, we generally find in its interior portions of sand, mud, or gravel, shells of fresh water testacea, fragments of roots or branches of trees, tubulariæ, larvæ, particularly of phryganeæ, imumerable animalcules, and different kinds of ova.

"In its living state, the Sp. friabilis is so soft and brittle that it can scarcely be handled or lifted without tearing, feels slightly unctuous between the fingers, has a strong disagreeable smell, like that of stagnant ditches in the heat of summer, tastes cooling without any marked flavour, and quickly diffuses among the saliva, leaving only some earthy particles between the teeth; it sinks slowly in water, appearing lighter than most marine sponges. When pressed, a thin slimy turbid greenish-coloured matter escapes, mixed with a considerable portion of water, and the remaining fibrous portion has a light grey colour, and stiff gritty feel. When allowed to putrefy in water, a thick, fatty layer covers the surface of the fluid, the water acquires a turbid yellowish colour, the Spongilla becomes of a blackish-green hue, and emits a most offensive putrid animal odour, like that of the most putrid offals. A portion of it, whether fresh or putrid, placed on a red hot iron, smells like burning skin or nembrane, the soft parts are dissipated, and the fibrous residne becomes red hot, but does not consume nor change much its form." Grant.

To this excellent description of the Spongilla by Dr Grant, I have only to add that, when growing in ruming water, it frequently assumes an arborescent form, rising to the height of from six to twelve inches and dividing, like a leafless shrub, into cylindrical tapered branches, which are often loaded with the 
seminal capsules. This state of it has been by many reckoned a distinct species, but the inconstancy and pliancy of the Spongilla is so great, that I readily assent to the opinion of Gervais, Blainville and others, who believe that even the most dissimilar of its forms are dependant on the varying influence of external circumstances. I have not been able to detect any essential difference in texture, or in the form of the spicula.

Dr R. D. Thompson, on an analysis of this species, found it to consist of,

$\begin{array}{llll}\text { Organic matter, } & \cdot & \cdot & 26 . \\ \text { Silica, } & . & . & 50.66 \\ \text { Carbonate of lime, } & . & . & 13.0 \\ \text { Phosphate of lime, } & . & . & 10.1 \\ \text { Alumina, . } & . & . & \text { a trace. }\end{array}$

99.86

According to Gmelin the powder of Sp. fluviatilis is employed as a vermifuge in Russia.

2. SP. LACUstris, "hard, brittle, and coarsely fibrous; spicula linear and doubly pointed."

Spongia lacustris, "Don's Animals of Forfarshire, 36."

Halicliondria lacustris, Flem. Brit. Anim. 524.

Hab. "In lakes in Angus and Fife," Fleming.

"Massive, rising into short rounded branches : the fibres are coarser, and the substance denser than the preceding; the spicula, too, though similar in form, are thicker, and about onefourth shorter." Fleming.-This difference in the spicula appears to prove the distinctness of this species, with which I am not acquainted.

I may here remark that some of the descriptions given of fresh-water sponges seem to have been derived from states of Alcyonella stagnorum. It is from a mistake of this kind that 
Lichtenstein was led to consider the fresh-water sponge as the nidus, not of the Cristatella, as stated by Lamarck, but of the Tubularia sultana of Blumenbach, which is a species of the modern genus Plumatella, (and probably only a state of the Alcyonella), and which, according to Blumenbach, is often interwoven with the Spongilla. Linnæus' description of Spongia fluviatilis, in the Flora Sneeica, leads to a conjecture thict he also had a state of the Aleyonella in view, for " semina Tentiformice" is a very apt description of its ova, and irreconcilable with the globular seeds of the sponge. And has not M. Laurent made the same mistake? In opposition to the experiments of Grant, Dutrochet, and Hogg, it is asserted that the experiments of M. Laurent " démontrent d'une manière évidente que le tube des jeunes Spongilles fluriatiles est irritable, c'est-à-dire susceptible de se contracter sous linfluence dirritans mécaniques." Revue Zoologique par la Societé Cuvierienne, for August 1838, p. 188. It is unnecessary to say that the young Spongillæ have no tubes.

"In ipsis rebus, quæ discuntur et cognoscuntur, invitamenta sunt, quibus ad discendum, cognoscendumque movemur." Crcero. 


\section{SPONGIA, Linnæus.}

Spongix pars, Liv. Lam. Lamour._Achilleum, Schweig. Beobacht. vii. Handb. 421.—Spongia, Flem. Brit. Anim. 524. Blainv. Man. 529.

Character. Body multiform, very porous, elastic, composed of a network of corneous fibres inosculating in every direction and traversed by tortuous canals opening on the surface by wider orifices; the fibres often contain imbedded spicula : gelatine fugacious: marine.

Obs. "IN the horny species of Porifera," says Professor Grant, " the skeleton consists of thin elastic tubular translucent filaments united together and distributed around the pores, canals and vents. These horny, tough, flexible threads have a close analogy in their mode of distribution through the whole interior of the body to the tough comecting matter of the spicula in the earthy species, and they give form and support to the whole fabric. Sometimes the internal eanal which extends through these tubular horny filaments is filled with an opake matter which gives a greater friability to the threads; but most frequently they contain only a transparent colourless fluid." Outlines of Comp. Anatomy, p. 8. 
The recent observations of $\mathrm{Mr}$ Bowerbank have shown that this description of the Spongiæ is erroneous. He has proved that the "filament" is solid; and he has also proved that it is often abundantly furnished with siliceous spicula. * It may be said that the latter species are properly members of the genus Halichondria, but so similar are they in appearance, form, structure, elasticity and bibacity to the purely horny or keratose kinds, and so unlike the typical siliceous ones, that the separation would be injurious to a natural arrangement, and would be hostile to the maxim "that a genus should furnish a character, not a character form a genus." + Indeed it is too evident that the distimction between the keratose and the siliceous sponges is one of degree only, not of essence : in the former the fibre is either entirely horny or it secretes minute spicula which are always imbedded in the centre of the tissue,-in the latter the animal matter has a greater secerning power, and in general the spicula lie exposed or predominate so far as to constitute the principal ingredient of the sponge. Yet there are species which commingle the characters of Halichondria and Spongia so intimately in their structure that we can at best but puzzle out their true genus.

Mr Bowerbank has also made the very interesting discovery

* " The small fibres usually have none and the largest abound in them. The young sponges are also frequently without them, but the adult ones never." Bowerbank in litt.

+ Linnæus " laid it down as a maxim, that all genera are as much founded in nature as the species which compose them; and hence follows one of the most just and valuable of all his principles, that a genus should furnish a character, not a character form a genus; or, in other words, that a certain coincidence of structure, habit, and perhaps qualities, among a number of plants, should strike the judgment of a botanist, before he fixes on one or more technical characters, by which to stamp and define such plants as one natural genus." Sir J. E. Smith's Introd. to Botany, p. 182. edit. 1833. 
that many species of this genus are distinguished by the possession of a beautiful branched vascular tissue, which surrounds the fibre, frequently anastomosing and running in every possible direction over its surface. This tissue is not imbedded in the horny mass of the fibre, but is contained in a sheath, which closely embraces it. In some of these vessels Mr Bowerbank observed numerous minute globules, exhibiting every appearance of being globules of circulation analogous to those found in the blood of the higher classes of animals. 'These molecules were extremely minute, varying from the $\frac{16}{16} \overline{6} \frac{1}{6}$ th to the $5 \frac{1}{5} \overline{0} \overline{0} \overline{0}^{\text {th }}$ of an inch in diameter.

In a recent state the surface of the Spongix appears to be covered with a reticulated membrane of more delicate organization and with finer meshes than the interior network. The interstices of the whole mass is as usual occupied with an organic mucus similar to that of the other genera ; and in some species it is not less loaded with minute siliceous spicula than are the fibres themselves.

The Spongiæ are propagated probably by gemmules generated in and from the organic mucus, as Mr Bowerbank has shown in one Australasian species.*

From their softness and indestructible elasticity, and their remarkable bibulous property, the Spongix are adapted to many economical uses. These are thus summed up by Ray :-_"Spongiarum multiplex usus est: nimirum 1. ad fomenta; multò enim diutiùs decoctorum quibus membra fovenda sunt calorem retinent, quam panni aut linteamina : 2. ad sanguinem aliumve liquorem imbibendum et exsiccandum, quo Anatomicis, Chirurgis, Mechanicis utiles sunt. 3. Ad ulcera cava, nondum

* For an account of Mr Bowerbank's discoveries on the structure of recent sponges, see the Microscopic Journal, i, p. 8 ; and the Annals of Nat. History, vii. p. 72. and I29. 
perfectè sanata, dilatanda et quamdiu opus est aperta te renda, et ad putrida exsiccanda. Ustarum cinere veteres usi sunt ad ocularia medicamenta, et ubi quid extergere opus est. Plerique recentiores Medici iisdem Spongia cineribus ex vino albo propinatis utuntur in cura bronchoceles, toto unius Lunæ curriculo, certissimâ experientiâ." Hist. Plant. i. p. 81.

1. S. PULCHELla, amorphous, consisting of finely reticulated simple fibres; the meshes quadrangular, minute; the fibre smooth and without spicula.

Plate XIX. Fig. 1. 2.

Spongia pulchella, Sowerby, Brit. Misc. 87, pl. 43. Jameson iı Wern. Mem. i. 562. Turt. Brit. Faun. 208. Montagu in Wern. Mem. ii. 109. Gray, Brit. Plants, i. 359. Flem. Brit. Anim. 524. Templeton in Mag. Nat. Hist. ix. 471. Bellamy's S. Devon, 268 .

Hab. Ireland, H, Brown. North Wales, Rev. H. Davies. On the shores of several of the Western isles of Scotland, Jameson. Hartlepool, J. Hogg. Coast of Berwickshirc. G. $J$. Found on the shore near Carrickfergus, Templeton. Plymouth, J. C. Bellamy.

Sponge generally arising from a circumscribed or narrow base, massive, very irregular and variable in its shape, but mostly conformed into sinuous crests and ridges, "although sometimes approaching to a fan-shape, and sometimes rather palmate or digitate," yellowish-brown, light and elastic, delicately reticulate. The principal fibres composing the network lave a longitudiual and parallel course, running from the base or centre to the circumference, but these are connected with numerous cross threads so as to form small quadrangular or rarely pentagonal meshes: the fibres smooth, pellucid and tubular, capillary or a little swollen at the points of inosculation. Vents scattered, small, eren with the surface, and hener, in sone specimens, in- 
conspicuous.- - This sponge is to some degree transparent, so that by holding it up to the light the parallel direction of the centrifugal fibres can be readily seen. When the gelatinous matter is entirely washed out, the sponge is soft and elastic, but if any of the gelatime remains the dried specimen is more or less rigid.

2. S. LiмватA, amorphous, usually lobed, fibro-reticular, the meshes rather large; the fibre smooth and full of minute spicula, which are needle-shaped and double-pointed.

\section{Plate XIX. Fig. 3, 4, 5.}

Spongia limbata, Montagu in Wern. Mem. ii. 111, pl. 15, fig. 2, 3. Gray, Brit. Pl. i. $360 . \quad$ Flem. Brit. Anim. 526.

Spongia lobata, Montagu in Wern. Mem. ii. 85, pl. 9, fig. 1. Flem. Brit. Anim. 526.

Tupha lobata, Gray, Brit. Pl. i. 356.

Hab. Parasitical on corallines and sea-weeds, and sometimes found incrusting the under surface of loose stones, between tidemarks. "Coast of Devon, surrounding the smaller stalk of some fucus, very rare," Montagu. Plymouth harbour, J. C. Bellamy. Berwick bay, G. J. Coast of Ireland, William Thompson. Dublin bay, A. H. Hassull. In a pool two miles from Roundstone, Connemara, attached to Fucus serratus, William $\mathbf{M}$ Colla.

Sponge growing in small subglobular or irregularly lobulated masses, from the size of a filbert to that of a walnut, of the usual yellow-brown colour of sponges, fibro-reticulated, elastic, and pervious to light, the meshes roundish or pentagonal, and so large as to be readily distinguished with the naked eye. The fibre is rather coarse, pellucid, smooth, very unequal, containing spicula, which are not visible excepting with a high magnifier. "The fibre is stonter than that of Spongia pulchella, and it anastomoses more frequently, and is exceedingly full of minute 
double-pointed needle-shaped spicula, very little curved, and uniform in size : they are mostly disposed in lines agreeing with the axis of the fibre, but occasionally cross each other at right angles, especially where a branch is given off. I did not detect a vascular coat on any part of the fibre." Bowerbank. In small specimens there is seldom more than a single osculum placed to one side and level with the surface; but in larger specimens there is an osculum to every lobe.

On the under surface of stones the growth of the sponge is modified by its untoward position, and it then forms a loosely reticulated spongy crust, from the eighth to about a quarter of an inch in thickness, perforated with several fecal orifices which remain always level with the surface.

Montagu's description of the species is as follows: "This sponge is firm and elastic; but the pores formed by the anastomosing fibres are considerably large : it is whitish when divided, and its lace-like appearance, when examined by a lens, renders it a beautiful object: the pores or interstices of the fibres are circular, and it frequently happens that numerous small pores surround a large one: and in most cases the intervals between the larger are filled up with smaller pores. The fibres are smooth, and destitute of any fimbriæ or detached inconnected parts."

After a comparison of many specimens, I have been bronght to believe that the Spongia limbata and S. lobata of Montagu are the same species, - the one in its primary, the other in its old and mature condition. The lotter he thus describes;"With clustered orate divarications."-—" The texture of this sponge is rather more coarse than that of oculate; the lobes vary from ovate to oblong, and originate from an ill-defined stalk in an irregular manner; they are nearly connected, sometimes inosculate, and are furnished with a few prominent pores without order. Colour yellowish-brown; height two inches.Devou coast ; rare." 
Mr M'Colla is of opinion that S. limbata is an annual species, since he found it in November, and there was no appearance of it during the summer months. Its term of existence can, at all events, not exceed that of the Fucus it grows apon, and this is usually an annual.

3. S. ? LEVIGATA, "soft, compressible, and elastic ; textur'e extremely fine and reticulated."

Spongia lavigata, MIontagu in Wern. Míem. ii. 95, pl. 16, fig. 4. Flem. Br. Anim. 526.

Scypha lærigata, Gray, Br. Pl. i. 358.

Hab. Coast of Devon? rery rare, Montagu.

"This is the most delicate of all the soft British sponges; when compared with either oculata or dichotoma, their texture is extremely coarse; by the naked eye, the surface appears nearly smooth, or finely frosted; when examined with the double lens of a megalascope, the surface is found to be minutely and elegantly reticulated, and of a cottony softness, but the fibres are infinitely finer than common cotton. Perhaps the texture in fineness would be more aptly compared to the interior spongy part of some species of puff-ball, (Lycoperdon.)

" The only small piece of this sponge that has come under" observation is tubular throughont; whether this is its natural habit, or the consequence of being a parasitical species that surrounds the stalks of fuci, or other marine plants, has not been discovered; but it is observable, that the central fibres radiate to the circumference; the summit, however, is rounded and perfect, like the finish of an independent species." Montugu.

A Spoxgia prolifera is enumerated among the sponges of the Firth of Forth by Dr Grant, (Edin. Phil. Journ. xiv. 116,) but he has given no description of it. The sponge referred, (erroneously as I believe,) by Templeton to the $S$. prolifera of Ellis and Solander, and dredged apparently in Belfast Lough, 
(Mag. Nat. Hist. ix. p. 472,) had undoubtedly been thrown out of some vessel, as Mr Templeton himself suspected; and an examination of the genuine specimen has satisfied me that the suspicion was well-founded.

Fig. 16.

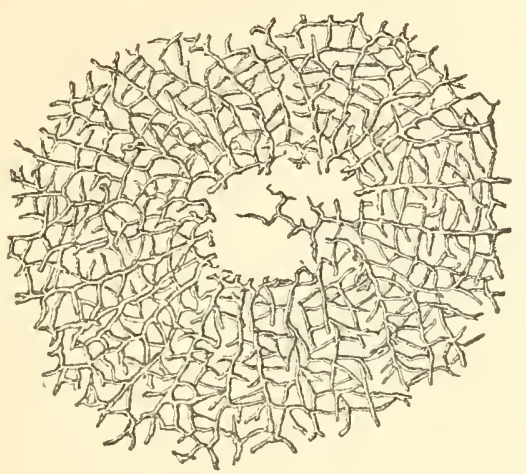

SPongIA : structure of.

" Nam, cum Natura (nt dici solet) non facial saltus, neque ab extremo ad extremum transeat nisi per medium, inter superiores et inferiores, rerum ordines nonnullas medise et ambigute conditionis producere solet, quæ de utroque participent, et utrosque velut conncetant, ut ad utrum pertineant ommino incertum sit."-J. Raius. 


\section{GRANTIA, Fleming.}

Spongiæ pars, Lin. Lam. Lamour.-Scyphæ pars, Gray, Brit. $P l$. i. 357._-Scyphiæ pars, Schweig. Handb. 422.-Grantia, Flem. Brit. An. 524. - Leucalia, Grant in Edin. Encyclop. xviii. 844.-Leuconia, Grant, Outl. Comp. Anut. 7.-Calcispongia, Blainv. Man. 530.

Character. Sponge firmish and inelastic, usually white, multiform, of a close texture lut porous, and composed of calcareous spicula compacted in a gelatinous base: spicula simple and stellated: oscula always distirct. Marine.

Ir has been already mentioned that Dr Grant was the first naturalist who ascertained that the spicula, which enter so copiously into the composition of sponges, were in some of them of a siliceous nature, and in others formed of carbonate of lime. To the latter group, the Rev. Dr Fleming, in 1828, gave the name of Grantia, with the view of commemorating the services of that gentleman in elucidating the physiology of the family. Dr Grant subsequently proposed to substitute " Leucalia" in lien of the first denomination, which Blainville changed. to "Calcispongia," that it might harmonize with his peculiar notions of the consistencies of nomenclature. Perpaps Dr Grant 
was actuated in making his alteration by regard to a canon which some have laid down,--that generic names commemorative of naturalists ought to be confined to botany ; but since there appears no sufficient reason for such a restriction, and since the canon has been too frequently violated to be now kept in integrity, e.g. Cuvieria : Mulleria : Montagua : Cavolina : Skenia : Leacia : Elfortia : Rissoa : Peronia, \&c. \&c. I willingly here adopt the original name of the genus, the more so as the labours of Dr Grant in various departments of zoology, and more especially as a professor of the science in the University College of London, claim for him the highest recompense which the cultivators of the same field have to bestow.

The essential character of the genus is the existence of spicula of carbonate of lime in the texture of the sponge, and the fact is readily ascertained by the effervescence which ensues on its immersion into a dilute acid. These spicula are crystalline, exceedingly numerous, partly triradiate and partly undivided, - the triradiate chiefly bounding the pores and orifices, while the curved ends of the others hang over the exterior entrances of the pores to protect them. When they are all entirely removed by the aid of an acid, the sponge becomes very soft and flexible, but still retains its original form and appearance; and if now examined with a microscope the residuum will be found a gelatinous membrane apparently of uniform and homogeneous composition throughout, without any pores or interstices, but with the cavities on the inner surface the same as in the perfect sponge. The Grantia differ, therefore, from nost other sponges in their base not being fibrous, and in their pores being rather of the nature of perforations than of meshes left by the interlacing of threads. From the number of their spicula, and their ealcareous quality, it happens also that the Grantiæ are more compact and close in texture than other sponges, and of a 
whiter colour; but, as in other sponges, the external surface is always of a closer texture than the inner.

The Grantia are properly littoral, growing on, or hanging from, rocks, sea-weeds, shell-fish and corallines, between tide marks, or in shallow water within the lowest ebb. In consequence of this their position, the circulation of water through their body has periodical interruptions, and it is said to be more languid than in some siliceous sponges inhabiting similar localities. Of its reality, Dr Grant's authority leaves no doubt, but its existence is less easily demonstrable than has been asserted. I have in vain made repeated experiments at all seasons to see it. I have becn equally unsuccessful in discovering anything like ova or gemmules in this gemus; nor is there any difference in the structure and composition of the sponge at any period of growth that is appreciable.

\section{* Tubular.}

1. G. compressa, compressed, leaf-like, with terminal and lateral orifices; surface even and porous; the spicula triradiate and clavate.

\section{Plate XX. Fig. 1.}

Spongia compressa, Fabric. Faur. Groenl. 448. Turt. Gmel. iv. 661. Bosc, Vers, iii. 176. Jameson in Wern. Mem. i. 562. Lamour. Cor. Flex. 48. Corall. 168. Grant in Edin. New Phil. Journ. i. 166 ; and ii. 122, 127, pl. ii. fig. 11, 12, 13, and 23 ; copied in Blainv. Atlas, p]. 94.

Spongia foliacea, Montagu in Wern. Mem. ii. 92, pl. 12. Templeton in Mag. Nat. Hist. ix. 471.

Scypha foliacea, Gray, Brit. Pl. i. 358.

Grantia compressa, Flem. Br. Anim. 524. Johnston in Trans. Newc. Soc. ii. 270. Bellamy's South Devon, 268. Hassall in Ann. Nat. Hist. vi. 174.

Leuconia compressa, Grant's Out. Comp. Anat. p. 7, fig. 3.

La Calcéponge comprimée, Blainv. Actinol. 531. 
$H a b$. On the sides of rocks and on sea-weeds near low water-mark. Bressay Sound, Shetland, Jameson. At Dawlish in Devonshire, Montagn. Near Tynemouth, not very plentiful, Miss Forster. From the circumstance of its having escaped the notice of Ellis, this species may possibly be rare on our southern coasts, but it grows in abundance on those of Scotland, G.J. Found not uncommonly in Ireland, according to $\boldsymbol{M r}_{\boldsymbol{r}}$ Templeton, and I have seen many specimens from various localities.

Sponge pendant by a narrow base, sometimes $1 \frac{1}{2}$ inch in height, and 2 inches in extreme breadth, usually about half this size, oval or somewhat triangular or pentagonal, greatly compressed, of a straw colour, becoming greyish in drying, the texture elose, the outer surface even and smooth, closely punctured, the inner reticulated with larger pores. It is hollow, and has at the top of small specimens, and at erery projecting angle of larger ones, a circular vent of considerable size with a plain rim. When left uncovered by the retreat of the tide the sides of the sponge are in contact, and the individuals hang like small white leaves from the surface of the rocks; "but, when suspended for a short time in pure sea water, their parietes separate, and they become like small distended bags pouring forth a continued and obrious current." Gront.-." The external surface is crowded with mumerous spicula, thick and bent at one cud, tapcring to the other; the pores on the inner surface are larger, and the spicula triradiated; besides these two well-marked forms of spicula, there are other linear, pointed, and of unequal lengths." Fleming.

Spongia compressa and $S$. foliacer of Esper have neither of them any relationship to Grantia compressa.

The Spongia urceolus of Muller, Zool. Dan. iv. 42, tab. 157 , fig. 3 , is probably a variety of the species with a single terminal aperture. 
2. G. LAcunosa, sponge flabellate, entire, the sides lacutnose; spicula all triradiate.

Plate XX. Fig. 2, 3.

Grantia lacunosa, Bean MSS.

$H a b$. On rocks at low-water near Scarborough, very rare, Mr. Bean.

Sponge half an inch in height, flabellate, pedicled, entire or undivided, white, greatly compressed, the sides perforated with numerous irregularly elliptical holes or vents, so as to give a lacunose appearance to the dried specimen: structure compact, friable when dry; spicula all triradiate. The remarkable character afforded by the numerons large holes in the sides, so unlike the fecal orifices of the other species, distinguishes this at once, and removes the suspicion of its being a variety of any other.

3. G. ciliata, sponge elliptical or tubular, rough and villous, the vent terminal and surrounded with a fringe of erect asbestine spicula.

\section{Plate XX. Fig. 4, 5. Plate XXI. Fig. 6, 7.}

Spongia ciliata, Fabric. Faun. Groenl. 448. Turt. Gmel. iv. 657. Bose, Vers, iii. 169. Lamour. Cor. Flex. 55. Corall. 151. Spongia coronata, Ellis and Solland. Zooph. 190, pl. 58, fig. 8, 9, copied in Esper. Spong. tab. 61, fig. 5, 6. Turt. Gmel. iv. 657. Turt. Brit. Faun. 208. Stew. Elem. ii. 433. Bosc, Vers, iii. 169. Montagu in Wern. Mem. ii. 88. Lamour. Cor. Flex. 54. Corall. 171. Lam. Anim. s. Vert. ii. 370. 2de edit. ii. 560. Schweig. Beobacht. 80, tab. 5, fig. 47. opt. 1 Grant in Edin. New Phil. Journ. i. 170; ii. 122, ple 2, fig. 17, 18, copied in Blainv. Atlas, pl. 94, fig. 17, 18.

Spongia panicea, Esper. Spong. tab. 18, fig. 1, 2.

Scypha coronata, Gray, Brit. Plants, i. 357.

Grantia coronata, Hassall in Ann. and Mag. Nat. Hist. vi. 174.

Grantia ciliata, Flem. Brit. Auim. 325. Johnston in Trans. Newr. 
Soc. ii. 271. Bellamy's South Devon, 269. Thompson in Ann. Nat. Hist. v. 254.

La Calceponge cilée, Blainv. Actinolog. 5:31.

$H a b$. Parasitical on the lesser Fuci and Confervæ, especially on the Delesserix and Ceramia. In the harbour of Emsworth, Ellis. "Not uncommon on many parts of the British coast ; I have found it in the most southern extremity, and have been favoured with it from Zetland by Mr Flening," Montagu. Isle of Man, Edw. Forbes. From the number of specimens sent me by $M r \cdot W m$. Thompson of Belfast, and $M r \cdot M r C o l l a$, from various localities, I conclude it to be common on the Irish coast.

Sponge hollow, cylindrical or ovate or elliptical, often curved and narrowed at the base, rough and hirsute with the projecting spicula, compact and unporous; the vent terminal, generally constricted, and encircled with a fence of long asbestine, usually connivent, spicula. It varies from a line to fully two inches in height. "The surface is closely covered with lincarpointed spicula, having a terminal direction; in the substance of the sponge, besides these linear, there are other triradiated spicula. The internal surface is full of irregularly-shaped pores." Fleming. "It should be remarked, that the specific character of being 'surrounded at top by a crown of spines,' is rarely identified; but the spicula that cover all other parts, form a lasting character. It is gencrally of a yellowish colour, sometimes of a shining silvery white; and this we may conceive is its true colour, could all adventitious matter be removed." Montagu.

This species, in general so well-marked, is occasionally as deceptive as any of its congeners. In the normal state, the sponge is elliptical, white, with a granular or muricated villous surface and a narrow ciliated vent, (Woodent, Fig. 1); but in the very large variety, from the coast of the Isle of Man, (Plate 
XX. Fig. 4), the surface is less distinctly muricated and more villous, while the oral spicula are comparatively short. To this variety the Sp. panicea of Esper belongs. Another variety is more elongated or cylindrical in shape, of an earthy colour, soft texture, strongly muricated and scarcely villous, while there are no prolonged spicula around the orifice (Plate XXI. Fig. 6, 7.) In this condition I have found it on the under surface of rocks near low-water mark, and to the peculiarity of its site, the modification of its characters is attributable. It appears to be identical with the Spoxgia fistulosa of Delle Chiaie, Anim. s. vert. Nap. iii. p. 113, tav. 37, fig. 14, 15.

When the sponge is allowed to decompose in water so far that the external spicula can be easily rubbed away, it will be seen that the granulations on the surface are arranged in regular series after the fashion of the scales on a fir-cone. The granules are equal and papillous, looking all towards the orifice. The simple spicula are very unequal in size, more or less curved, linear but acute at both ends, which are alike: these, howerer, are generally broken away so that the spicula appear to be truncate. The triradiate spicula are not less variable in size, and frequently one of the prongs is considerably longer than the other two.

4. G. вотryoides, clustered, very irregularly branched, the branches ovate or cylindrical, tubular, with a terminal plain orifice; spicula triradiate.

Plate XXI. Fig. 1-5.

Spongia botyroides, Ellis and Soland. Zooph. 190, pl. 58, fig. I -4, copied in Esper Spong. tab. 61, fig. 1-4. Turt. Gmel. iv. 660. Turt. Brit. Faun. 209. Stew. Elem. ii. 434. Bosc, Vers, iii. 173. Montagu in Wern. Mem. ii. 89. Lamour. Cor. Flex. 81. Corall. 184. Lam. Anim. s. Vert. ii. 382. 2de edit. ii. 573. Templeton in Mag. Nat. Hist. ix. 471. 
Sp. complicata, Montagu in Wern. Mem. ii. 97, pl. 9. fig. 2, 3. Gray, Brit. Pl. i. 358. Grant in Edin. New Phil. Joum, i. 169. Spongia confervicola, Templeton in Mag. Nat. Hist. ix. 470, fig. 67. Scypha botryoides, Gray, Brit. Pl. i. 357.

Grantia botryoides, Flem. Brit Anim. 525. Jolnston in Trans. Newc. Soc. ii. 270. Bellamy's S. Devon, 268.

Calcispongia botryoides, Blainv. Actinol, 531.

$H a b$. On the under surface of stones and, more abundantly, on the smaller Fuci and Conferve, between tide-marks: very common on the shores of Ireland, Scotland, and the north of England, but as Montagu had never gathered it, the presumption is that it is rare in the south. Ellis's specimen was got " in the harbour near Emsworth, between Sussex and Hampshire."

Sponge very variously, but always irregularly branched, delicate, white, of a close texture, without risible pores on the surface, which, under the magnificr, appears somewhat villous; the orifices terminal, even and unarmed. It varies infinitely in its mode of ramification: the branches are sometimes short, orate and clustered, or spreading and laid close to the body on which they grow: at other times they are about an inch in height, ereet, cylindrical and tubular; sometimes they are flattish and fimbriated or almost pinnate, and in other specimens the branches inoseulate in an irregular manner; but the most abnormal of its states is when it grows on the under surface of a flat stone, for then it crecps and ramifies in slender filiform branches like a conferva, inosculating irregularly, and throwing up at intervals single tubular clliptical processes. It reminds one, in this state, of the inalogous growth of some agaries which. when prevented by the pressure of any superincumbent body from growing in their usual nanner, will germinate and evolve a white feathery. byssus-like production, which some botanists have described under the name of ITimantia. All the spicula are triradiate, the forks acutely pointed. 
Mr Montagu has endeavoured to draw a distinction between his Sp. complicata and the Sp. botryoides of Ellis,-the spicula of the former being, he says, not a quarter so large as those belonging to the latter. But Montagu acknowledges that he had never seen a specimen of Ellis's Sp. botryoides, and its presumed spicula, sent to him by Mr Boys, were probably those of Grantia compressa. And no argument derived from a diversity in habit between his specimens and those figured by Ellis, ean be relied upon, as an examination of a very extensive series of specimens has fully satisfied us.

\section{G. pulverulenta, "ovate, thick, pulverulent, vil- lous."}

Spongia ananas, var, Montagu in Wern. Mem. ii. 97, pl. 16, fig. 3. Sp. pulverulenta, Grant in Edin. New Phil. Journ. i. 170.

Scypha ovata, Gray, Brit. Pl. i. 358.

Grantia pulverulenta, Flem. Br. Anim. 525. Bellamy's S. Deron, 269.

Spongia inflata, Della Chiaie, Anim. s. Vert. Nap. iii. p. 114, tar. 37 , fig. $16,17$.

Hal. On corallines, rare. Devon coast, Montagu. Zetland, attached to Sertularia cupressina, Fleming.

Sponge about the eighth of an ineh in height, attached by a narrow base, orate, white, the surface villous with the prominent spicula which point upwards, the orifice terminal, contracted and encircled with a close fringe of erect spicula of a silvery white colour. The spieula are of two kinds: "one of these forms is a triradiate spiculum with long and very slender rays diverging at equal angles; the other is a very long straight needle-shaped spiculum, pointed acutely at one end, and obtuse at the other." Grant.

Montagu suspects that this is his Spongia anamas, Wern. Mem. ii. 96, pl. 16, fig. 1, 2, "in a more perfect state," but Dr Fleming appears to consider them distinct. The following 
is Montagu's description of the SP. ANANAS: "This elegant minute sponge is nearly allied to coronata, but is very different in shape and texture ; the surface is not covered with spiculæ as in that species, but is apparently vesicular or scaly, and when magnified, somewhat resembles an extremely fine Millepora, except that no openings or pores are visible, nor is it of the same consistence."

6. G. Fistulosa, simple and compressed, the surface villose, the vent terminal and naked; spicula triradiate, very unequal.

Plate XX. Fig. 7.

Hab. Coast of Ireland. Portaferry, Wm. Thompson.

Sponge forming a long simple tube, perhaps subcylindrical when recent, three or four inches in height, and about half an inch in diameter, attenuated at the base, with a wide even vent at the opposite truncate extremity; the surface not porous nor muricated but shortly villose ; the walls imperfectly cellular : spicula triradiate, very unequal in size, the rays diverging also at various angles, often very long and even flexuous. Some of the spicula are remarkable for their great size; and there appears to be intermixed with these compound sort a simple one shaped like a needle, but these may be merely rays of the other broken away near the base.

The specimens I have secn have attached to their base the stalk of some slender fucus which grows usually near low-water mark. In a dried state the sponge is of a whitish colour and friable.

\section{*** Crustaceous.}

6. G. NIVEA, of a close texture, pure white, the fecal orifices small and level with the surfuce; spicula triradiate and yuadriradiate. 
Plate XXI. Fig. 8.

Spongia nivea, Grant in Edin. Phil. Journ. xiv. 339; and in Edin. New Phil. Journ. i. 168; and ii. 139, pl. 1, fig. 14-16, copied in Blainv. Actinol. pl. 94.

Grantia nivea, Flem. Brit. Anim. 525.

Calcispongia nivea, Blainv. Actinol. 531.

$H_{a b}$. On the under surface of sheltered rocks at Prestonpans Bay, during the ebb of stream tides, Dr Grant. On the Northumberland coast at Dunstanborough eastle, $M T \cdot$ Robert Embleton. At Scarborough, $M T \cdot$ Been.

Sponge incrusting, spreading irregularly to the extent of one or two inches in diameter, from one to two lines thick, snowwhite, of a light close texture, the surface shortly villose, eren or unequally protuberant or crested and waved, the under side imperfectly cellular; fecal orifices scattered, small, round with a plain margin and level with the surface: the whole sponge composed of spicula irregularly compacted, the triradiate very numerous and of various sizes, some being minute and others so large as to be visible by the naked eyc. "The second form of spiculum in the $\mathrm{S}$. nivea is the most remarkable, though the rarest; it consists of a straight line, with two opposite lateral projections in its middle, which are generally a little curred. When these lateral processes are large and straight, it becomes a regular quadriradiate spiculum, but they are generally much shorter than the other two rays; and when they are placed near one extremity of the spiculum, it appears under the microscope like a small dagger with a handle. The quadriradiate spicula are generally very minute, and in number about one to a hundred of the triradiate. The third kind of spieulum in this species is a very minute straight equally thick spiculum, obtuse at both ends, and generally about the fiftieth of a line in length ; this form is very abundant, and may possibly be derived from the broken rays of very small triradiate spicula, as in the com- 
pressa. These three kinds of spicula are likewise calcareous, and dissolve with rapid effervescence on being touched with diluted nitric acid. On looking closely into the surface of the $S$. niver, with a single lens, we perceive that the large triradiate spicula lie parallel with the surface, and contribute to form and protect the pores." Grant.

$\mathrm{Mr} \mathrm{M}^{\prime}$ 'Colla has furnished me with a variety from the Irish coast that merits to be distinguished. The sponge rises up in compressed sinnous leaf-like lobes, which are united together so as to form a lobulated crust nearly an inch in thickness, with a circular osculum on every projecting angle. (Plate XX. Fig. 6.) Were we to imagine that a cluster of Grantia compressa had grown so close as to press against each other, and the various specimens to have coalesced into one mass, we would have a correct idea of this varicty. That it is, however, no variety of $\mathrm{Gr}^{\circ}$. compressa is proved by the difference of its texture, as well as by the form of the spicula.

7. G. CORIACEA, incrusting; texture cancellated, fibrofleshy; the spicula minute, triradiate.

\section{Plate XXI. Fig. 9.}

Spongia coriacea. Montagu in Wern. Mem. ii. 116. Gray, Brit. Pl. i. 361. Flem. Brit. Anim. 526.

Crantia multicavata, Bean, MSS.

Hab. On rocks between tide-marks. Scarborough, Mr Bean. Berwick Bay, G. J. Dublin Bay, A. II. Hassall.

Sponge incrusting, spreading irregularly, from one-cighth to one-fonrth of aninch thick, dirty bluish gray or white when recent, changing to yellowish-brown when dried or immersed in freshwater, of a fibro-carneous substance, soft and easily torn in any direction, not elastic ; surface plain or uneven, cancellated, the meshes or pores large, roundish, and separated by a thick line: 
there are no fecal orifices : interior fibrous and reticulated like the surface: spicula numerous, minute, calcareous, all of them triradiate, brittle, the rays pointed, not projecting at the surface. This sponge has a fleshy feel and tear, and a somewhat coriaceous appearance; and by the size of its pores and its consequent cancellated structure, differs remarkably from every other species of the genus.

The following is Montagu's description of his ${ }^{-}$Spongia coriacea. It answers well to the specimens before me, but the agreement is perhaps not close enough to remove all doubt of the identity of his species with mine. "The fibres that constitute this sponge," he says, " are composed of very fine spiculæ, and are intersected with numerous large pores and cavities, giving the appearance of singed leather, or a piece of dark-coloured wormeaten wood in a very decayed state. One side is rather smooth, with circular depressions or cavities. The only specimen that has occurred is depressed, four inches in length, and above two in breadth."

Fig. 17

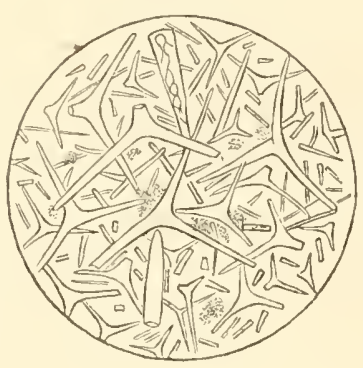

Sercula of Grantia. 


\section{DUSEIDEIA,* Johnston.}

Character. - Sponge multiform, sessile, imperfectly cellular, composed of a gelatinous membrane or basis containing or frosted with amorphous particles of sand.

Proceeding on the principles adopted by Dr Fleming in the division of this family, I find it necessary to form a new genus with the sponges that possess the above character; and this I have named Duseideia because of its want of beauty and attraction. $t$ These sponges are evidently of a lower grade in organization than the other genera. Their basis is a soft gelatinous unfigured membrane becoming friable when dried, and in which is imbedded or crusted a sort of gravel that seems to be extraneous; for although its particles are tolerably uniform in size, and more or less perfectly cubical, yet, from their uncrystalline state, their irregular aggregation, and their composition, which is neither siliceous nor calcareous, we conelude that they are not the products of any process of secretion, or in-

- Suresfer $x$,-ugliness.

$\dagger-\square_{-}-$"rudis indigestaque moles, Nec quicquam nisi pondus iners; congestaque eodem None bene junctarum discordia semina rerum."

Orid, Metam. i. v. 7. 
ternal action in the sponge. It is, however, to be observed that the gravel is very intimately mixed up with the membranous and fluid basis, and appears to be essential to the maintenance of the consistency and figure of the species.

Mr Bowerbank introduces his deseription of two species of this genus with the following remarks:- " The sponges which I have now to describe are exceedingly anomalous in their structure, especially the first of the two which I received with many others from my friend, Rupert Kirk, Esq. of Sydney, Australia, who procured it from the eoast in his immediate neighbourhood.

"Hitherto we have found that where silex has been the material with which the skeleton of the sponge tribe has been strengthened and supported, that earth has always been presented to us as a true animal secretion; either in the shape of spicula of various forms, or of very minute spherieal molecules; but in this species, although in great abundance, it is decidedly of extraneous origin, consisting of numerous grains of sand built into the substance of the fibrous skeleton of the animal, without any definite arrangement; the whole being stirrounded externally by a coating of the cartilaginous or horny matter of which the foundation of the skeleton is construeted, and with which we are so familiar in the sponges of commerce.

"We are acquainted with many instances in which extraneous substances are employed externally to assist as a covering or defence; as among the Mollusca by Trochus agglutinans, which attaches to the exterior surface of its shell the small shells and fragments of bivalves, or of any other substance that suits its purpose. We observe also among the aquatic larvæ, that the cases in which they pass so great a portion of their existenee is in many species most ingeniously and beantifully built up of fragments and small stems of plants, bits of shells, and other materials ; and in Sabella Belgica, so common on our own coast, 
the animal resides in an elongated conical tube, which is constructed in the most symmetrical and beautiful manner of grains of sand cemented together by a strong cartilaginous or horny matter; but in no instance that I am aware of have we found the animal skeleton formed from extraneous material, as in this curions and new form of sponge."

1. D. FRAGILIs, amorphous, " fragile, friable, coursely" reticulated, the fibres rugose, as if covered with mimete sand."

Plate XiII. Fig. 6 ; and Plate XIV. Fig. 4.

Spongia fragilis, Montagu in Wern. Mem. ii. 114, pl. 16, fig. I, 2. Gray, Brit. Pl. i. 360. Flem. Br. 'Anim. 526. Templeton in Nag. Nat. Hist. ix. 471.

Hab. Coast of Devon, Montagu. Scarborongh, Mr Bean. Found on various marine substances dredged up in Belfast Lough, Templeton. Isle of Man, E. Forbes.

Sponge without form or beauty, sessile, massive, of a coarse texture and earthy brown colour, irregularly cellular, incompressible and inelastic, tenacious enongh and gritty to the feel when recent or wetted, but, when dry, friable and easily monldering between the fingers into a coarse powder. The sponge is composed of a gelatinous membrane formed into a rude cellular mass, the divisions between the cells being erusted over with arenaceons particles, which give the membrane a frosted appearance when examined with a pocket-glass. There are a few irregular and perhaps adventitious spicula; and the small quantity of calcareous matter which enters into the sponge is certainly so.

It is only after the animal matter has been washed from the skeleton by tossing in the sea, that this sponge can be confounded, even by a cursory observer, with Halichondria fruticosa.

'To this deseription, made from dried specimens, Mr Bower- 
bank allows me to add the following fuller and more accurate one :-

"Form massive, variable, sessile; surface exasperated, of a dull ochreous colour. Exeurrent eanals few, large ; fibres of the skeleton rigid, coarsely reticulated, rugose, with numerous grains of sand imbedded in their substance; or tubular with few or no grains of sand imbedded; spicula of the skeleton variable in size and form, imbedded withm, or attaehed to the onter surface of the pore.

" The form of this species is exceedingly variable. In its young state, it is spread over the surface to which it is attaehed, as if it were a eoating sponge, but when fully developed, it rises to the height of two or three inches, and has a tendency to assume a thickened fan shape, or compressed form; and the base is usually twiee or thrice as long as it is broad, as if this were the natural mode of its developement. It is of a dull yellow ochreous eolour, and has the surface much aspirated by the projeetion of numerous stout sandy fibres. The exeurrent eanals are large and few in number, and have their terminations occasionally projected beyond the surface. The fibre of this species varies eonsiderably in its character. The larger and coarser portion is construeted of grains of sand of various sizes, encysted separately in the substance of the horny structure. Among the arenaceous fibres there are others of a fistulose structure, which have few or no grains of sand imbedded in them. In the largest of the arenaceous fibres, the grains of sand are accumulated in such numbers, and so closely built together, as frequently to render the fibre nearly impervious to light; but in the smaller ones, they are few in number, and disposed in nearly the eentre of the fibre. A few spienla are oceasionally found imbedded among the grains of sand, or attached to the surface of the fibre. The tubular fibres are smaller than the arenaccous ones, but originate from 
them, and freely anastomose with them. The fistulose cavity is large, continuous, and contains an abundance of spicula of a variety of sizes and forms. In the smallest of these fibres, the spicula are usually disposed in a longitudinal direction, but in the larger ones they are disposed without any apparent order, and assume every possible direction. Sometimes the small tulbular fibres suddenly expand to twice or thrice their original diameters, and again contract to their former size, the cavity expanding in proportion, and containing a great accumulation of spicula ; at other times the tube beeomes attenuated, and terminates by attaching itself to a grain of sand eight or ten times its own diameter, around which it spreads its horny structure until the grain is entirely enveloped by it, and firmly supported, as it were, upon a pedestal. These isolated grains are probably but the first stones in the foundation of the future large arenaceous fibres. Occasionally, we find a few small grains imbedded in or attached to the external surface of the fistulose fibres, and then the spicnla are less in number in their immediate neighbourhood; but usually they are without grains of sand. These fibres also appear to be destined to perform another important office in the economy of the animal,- for in many of the Brighton speeimens of this species I observed ova or gemmules of various sizes imbedded in the parietes of the tubes; some of them projecting from the inner surface towards the centre of the fistulous earity, but the greater number were projeeted from the onter surface of the fibre in all degrees short of absolute separation. When riewed as transparent objects, with a power of 300 linear, these gemmular bodics have a large opaque nucleus, of a somewhat gramulated character, whieh fills the whole of its interior, and is surrounded by a thin hornylooking shell or coat.

"The spicula are exceedingly variable in size and form. The greater portion of then are slightly curver, and attenuating to- 
wards each end, terminating in some acutely, and in others somewhat obtnsely ; others have their bases elliptical or globular, as in Fig. a, of Plate XIII. Occasionally, but much more rarely, we observe them furnished with numerous spines or tubercles, as represented by Fig. $b$, and still more rarely they are multiradiate, and of great comparative size, as represented at Fig. $c$. I could not detect any peculiar form of spiculum in the fleshy substance which fills the interstices of the skeleton, but I observed one or two detached spicula imbedded in its substance, of the form represented by Fig. $d$. This interstitial fleshy matter is of a firm consistence, and has dispersed throughout its substance numerous round or oval bodies varying from the $9 \frac{1}{90} 0$ to the $\frac{1}{40} \overline{0} \overline{0}$ of an inch in diameter; containing usually one, but sometimes two nucleii. These bodies are nearly uniform in their colour and general aspect, and present every appearance of being the cytoblasts whence the cellular substance of the animal is derived."

2. D? PaPillosa, cylindrical and tubulur with a truncate dimpled apex.

Plate XVI. Fig. 6, 7.

Spongia suberia, Johnston in Mag. Nat. Hist. vii. 491, fig. 60.

Hab. Parasitical on old shells. Scarborough, IIr Bean. Strangford Lough, Wm. Thompson.

Sponge in the form of a cylindrical pap, from three to six lines in height, and one or two lines in diameter, of a uniform arenaceous colour, smooth, close and compact in texture, tubnlar, the apex circular, with an obtuse rim, ocellated or depressed in the middle, to which some faint strix converge from the circumference. The sponge is composed of a thin membrane, loaded with unequal cubical grains of quartoze sand, arranged without order, but closely packed like a miniature parement. 
By a longitudinal section of it, we discorer that the sponge is tubular and empty in its lower half, but the upper is more or less filled with a confused granular mass adherent to the sides; and by a section in the contrary direction, a regular, thongh obscure, circle of cells may be detected, in each of which there seems to be a small white globular egg or oviform body. From this structure I am led to believe that the D. papillosa is really the nidus of some invertebrated animal, probably of a species of Natica. Whaterer it may be, it is found sometimes as a single mammiform process, but commonly it is gregarious, and the various processes may be united together by a thin crust, of the same texture and composition, spreading orer the shell on which the sponge is parasitical. Thus, in the specimen from Mr Bean here figured (Fig. 18.) the crust has so buried and veiled the shell that its species is not recognizable.

The figure which Montagu has given of his Spongia larigata might lead to the conjecture that it and D. papillosa were the same thing, but the descriptions will by no means tally.

Duseideia papillosa is nearly allied to the Alcyonium ocelletum of Ellis and Solander, Zooph. p. 180, tab. i. fig. 6 ; and it is probable that the two productions are of the same nature, whaterer this may be.

Fig. 18.
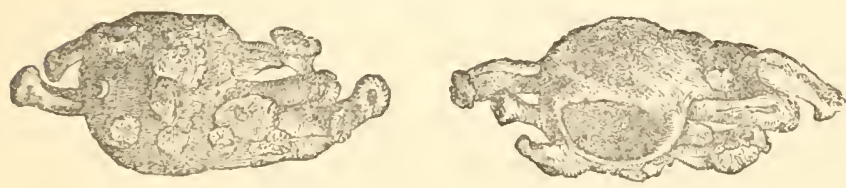

DUSEIDEIA PAPILLOSA. 
7. HALISARCA, ${ }^{*}$ Dujardin.

Character. Substance fleshy or rather gelatinous, semitransparent, unorganized, forming an irregular crust on the objects to which it adheres.

\section{H. Dujardini. Plate XVI. Fig, 8.}

Halisarca, Dujardin in Ann. des. Sc. Nat. n. s. x, 7, pl. 1, fig. 5.

$H a b$. On the under side of stones between tide-marks, and on the stalk and roots of Laminaria digitata, common. Berwick Bay : Holy Island, G.J.

Sponge in the form of a gelatinous crust, spreading irregularly, about a line in thickness, the surface eren and smooth, of a straw or ochre-yellow colour, mottled with little pale circular spots or pores, produced apparently by a deficiency of colouring matter in their places. A few of these transparent spots are larger than the others; and, if the former have any relation to the pores of the true sponges, the latter may be the analogues of the fecal orifices.

This production is liable to be mistaken for one of the crustaceous compound Tunicata, or rather for the gelatinous spawn

* From dixcos, marine, and $\sigma \alpha \rho \xi$, flesh. 
of the naked mollusca, but a careful inspection easily detects the difference. This exhibits no trace of any oviform bodies or eellular tissne, and contains neither crystals nor spicula, but is no other thing than a mass of irregular and granulous globules, of great minuteness, that lie imbedded in a clear jelly, covered over with a more eonsistent and coloured skin. Dujardin has ascertained that when broken up, the separated masses shoot out from their sides delicate prolongations or filaments of various lengths, and slowly change their figure, in the same manner as do the detaehed sarcoid pieces of the fresh-water sponges.-(See woodcut, No. 9, p. 61.) 


\title{
ADDITIONS AND CORRECTIONS.
}

\author{
The Siliceous Spicula, p. 8, 89.
}

From the recent researches of $\mathrm{Mr}$ Bowerbank we learn, that the forms of the siliceous Spicula are more diversified than was previously believed; and that they are, perhaps, even more varied than those of the calcareons sponges. The triradiate form is certainly not peculiar to the latter.

The Circulation of the Sponge, p. 14.

Mr Hogg has informed me, that he has also seen the circulation of a marine sponge in Halichondria panicea. He could not detect any evidence of an influent current; neither did he detect, with the magnifier he used, any circulation whatever in Grantia foliacea. I am not aware that Mr Hogg has abandoned his opinion of the circulation being, as it were, alien and accidental, and dependent on nestling animals.

\section{The Propagation of Sponges, p. 18.}

Mr Bowerbank's researches seemingly tend to prove the correctness of Professor Grant's description of the gemmules of the sponge, although he has not actually scen the cilia in those of any recent species which have yet come under his observation. Some observations made by Mr Bowerbank on fossil sponges lead to a suspicion, that, in some, there may have been an appropriate organ for the production of the gemmules.

\section{Fossil Sponges, p. 22.}

In explanation of these, I refer the reader to a very interesting paper by J.S. Bowerbank, "On the Siliceous Bodies of the Chalk, Greensands, and Oolites," published in the sixth volume of the Transactions of the Geological Society of London, p. 181. Lond. 1841. 
Tethea Lyncurium, p. 85.

Under the description of this species, (p. 86, I have expressed a belief that it and the Cydonium Mulleri of Fleming were identical, but having since received from the Rev. Dr Fleming a slice of his Cydonium, I am now aware that my conjecture was entirely erroneous. The Cydonium in question is a species of the genus GEODIA of Lamarck, provided the definition of that genus is modified so as to meet the views of Milne-Edwards. See p.57. I have therefore to introduce to my readers a native species of this very interesting genus, which, in a system of classification, should take its place nigh to Tethea.

\section{GEODIA,* Lamarck.}

Geodia, Lam. Anim. s. Vert. 2de edit. ii. 593.-Audourn et MilneEdwards, Hist. Nat. du Kitt. de la France, i. p. 77. Blainv. Man. 534. SchweIg. Handb. 422.

CHARActer. Sponge tuberous, solid, permeated with ir. regular sinuous canals; the interior composed of siliceous spicula collected into fuscicles, and laid amid un organic sarcoid mutter; the surface covered with a solid crust composed of siliceous globules closely agglutinated together. Hirarine.

1. G. ZeTLANDicA, the crystals of the surface globular, with a minutely reticulated surface.

$$
\text { Plate III. Fig. 3, } 4 .
$$

Alcyonium Cydonium! Jameson in Wern. Mem. i. 563. Stew. Elem. ii. 432.

Cydonium Mulleri! Flem. Brit. Anim. 516. Grant in Edin. New Plil. Journ. i. 195. Jolnston's Brit. Zooph. 191.

Hab. Deep water. "Island of Fulah and Unst," Jameson. The interior of this remarkable sponge is fulvous and of a loose cottony or asbestine texture when dry. The spicula are numerous and collected into bundles trending from the base or centre to the skin, which some of them penetrate, but the points scarcely project beyond the surface. A sheath of organic mat-

\footnotetext{
" From zeadus, earthy, earthlike.
} 
ter invests each spiculum; and the spicula are also connected together by an organic membrane filled with minute transparent granules, and probably soft and mucilaginous in a recent state.* The spicula are in general long, stout and fusiform, rather acutely pointed at both ends; and with the larger ones there are intermixed some of more slender proportions. and some of those which tonch the skin are forked with two or three prongs, to support, as it were, the globules which constitute the crust. This, when dry, is of a chalky-white colour, with a dusky subvillose surface, dimpled in some places with numerous pores placed pretty closely together, and large enough to be visible with the naked eve. It is scarcely a line in thickness, and is composed of a congeries of innumcrable globules prettily arranged and cemented together by an organic mucus, so as to form a solid parement. The little globules are not all of the same size, though mostly so, and, when highly magnified, their surface appears minutely reticulated. They are solid erystalline balls of silex.

This description is made from the portion of his specimen which Dr Fleming kindly sent me. The sponge has a close and evident relationship to the "Alcionio primo di Dioscoride" of Donati, (Stor. Nat. Mar. dell' Adriat. lviii. tav. 8, fig. A, B, C, $\mathrm{D}, \mathrm{E}, \mathrm{F}, \mathrm{G}$,) but in this the spicula are represented as projecting far beyond the crnst. The relationship is not less close to the Geodia tuberosa of Schweigger, (Beobacht. p. 40, pl.iii. fig. 18, 19, ) but the imperfection of his description forbids us to pronounce on the sameness of the two. Schweigger eren speaks of the fibres or spicula being intermixed with lime, but he was undoubtedly deceived by the white chalkiness of the crust.

Schweigger"s Geodia tuberosa is synonymous with the Geodia

* "The fleshy matter surrounding the great radiant spicula is a very beautiful structure, highly cellular and abounding in cytoblasts. There is also a beautiful rascular tissue meandering through it in every direction, and in some of these ressels there are molecules similar to those 1 bave described as existing in some parts of the vascular tissue surrounding the fibre of one of the sponges of commerce. In this same flesby matter I also observed a few stellate spicula." J. S. Bouerbank. 
gibberosa of Lamarck, (Anim. s. Vert. 2de edit. ii. 594,) and of Blainville; (Man. d'Actinol. 535, pl. 9l, fig, 4.) and is said to be a native of the shores of Guinea.

Halichondria saburrata, p. 120.

From an inadrertency, which I cannot explain, the spicula of this sponge have been described as " short, curred and double-pointed." They are, on the contrary, short, obtuse at one end, and pointed at the other. and in fact are so like those of Halichondric incrustans as, perhaps, to prove that H. saburrata mar be reckoned a mere variety of that species.

HaLichoNdria AREOLATA, p. 121.

I suspect that this is a crustaceous state of Duseideia fragilis. An examination of a specimen of the latter in a fresh condition, giren me by Mr Bowerbank, has forced this conriction upon me.

\section{HALICHOXDRIA SERIATA, p. 125.}

The spicula are considerably shorter than those of $\mathrm{H}$. incrustans, rather thick, more or less curred and anl-shaped. The one end is obtuse, the middle bulges a little, and thence the spiculum tapers to a point. The membrane that incests the central carity of the spiculum is rery obrious in this species.

\section{HALICHONDRIA CELATA, p. 125.}

Mr William Thompson lately sent me an old and much wormeaten oyster shell marked, on the inner surface, with a circular white flocculent or spongy incrustation which, on a microscopical examination, prored unexpectedly to be a state of $\mathrm{H}$. celata. It had no connection with the perforations in the shell; and no resemblance to the sponge in its normal state.

\section{Halichondria virgultosa, p. 137.}

When entire, the spicula appear mostly to have a small head. and to be shaped like a slender pin.

\section{HALICHONDRIA SUBEREA, p. 139.}

On examining the spicula anew; with a better microscope 
than I had previously been able to use, I found them to be formed like a pin with a distinct head, and most of them perforated with a central canal.

HALichondria sevosa, p. 147.

The spicula are fusiform, curved, tapered to a sharp point at each end: they are all alike in form, and not very disproportioned in size.

\section{Halichondria albescens.}

Cuaracter. Sponge fibro-fleshy, simple, pearshaped with a subterminal osculum; spiculum short, slightly curved, linerer but acute at both ends.

\section{Plate XX. Fig. 8, 8.}

Hab. Parasitical on Sertulariæ in Berwick Bay.

Sponge about half an inch in height, simple, pearshaped, fibrogelatinous, solid and almost transparent, of a watery-white colour, apparently smooth, but the magnifier shows it to be subvillous and minutely granulated without any perceptible pores. There is usually a single osculum near the apex, circular with a plain rim. The spicula are connected in a reticular manner and intervoven amid the organic mucus: they are neat, short, differing very little in length, but some are about twice as thick as others. The species may be placed next to H. fucorum.

\section{HALichondria Johnstonia.}

Bowerbank, MS.

Description._-" Massive, sessile, surface undulating, encrusted. Terminations of the excurrent canals disposed on the most elevated part of the surface, depressed, sometimes bounded by a slightly elevated marginal ring. Incurrent canals inconspicuous. Colour of the crust slate-gray ; of the interior substance dull yellow. Spicula of the skeleton mostly simple and slightly curved, rarely attenuating towards their ends, but usually of equal diameter throughout their whole length, having hemispherical terminations: sometimes, but rarely, triradiate or irregularly branched. Spicula of the flesh minute, stel- 
ate rays attenuating regularly to their apices. Spicula of the crust simple, minute, and fusiform, having their surfaces irregularly tuberculated, and their terminations very obtuse.

"This sponge is found attached to the Thatcher, and other rocks in the neighbourhood of Torquay about low-water-mark. The parts of the crust which are most exposed are of a dark gray colour, sometimes almost approaching black, while the marginal portion near the base is frequently of a light gray and occasionally almost white. The crust varies from about a quarter to half a line in thickness. The interior substance is of a dull yellow colour, firm in texture, and very much resembling the crumb of bread in its appearance. It is traversed by numerous large excurrent canals of about the tenth of an inch in diameter, which pass in a tortuous direction from the base of the sponge to the most elevated parts of its surface, where they terminate in depressed areas, which are sometimes surrounded by a slightly elevated marginal ring. These orifices are frequently disposed in parallel lines, which occupy the summits of the ridges that intervene between the depressed parts of its surface.

"The great variety that exists in the form of the spicula of this species is very remarkable. The most common is that of a simple slightly curved cylindrical spiculum, of equal diameter throughout its whole length, with hemispherical terminations. Occasionally, but not very frequently, there is a single spiculum to be seen, in which there is a gradual attenuation towards one end, but in all the cases that I have observed of this description, it does not terminate acutely, but as in the normal form, hemispherically. Among the common forms there are frequently to be observed large triradiate and irregularly branched spicula, which have their radii usually terminating in a simple point; but they are sometimes bifurcated. The central cavities are distinctly visible in these spicula, and in the compound ones there is a free communication between all their parts. In some of the spicula the central cavity is much larger than in others, and it may be observed with great advantage if a small portion of the sponge is burned to a white ash in the 
flame of a lamp, and then mounted in Canada balsam. The transparent memblane lining the interior of the spicula is converted by this means into an opaque carbonaceous film, which becomes distinctly visible to the observer.

"If the fleshy substance of the sponge be examined by transmitted light, with a power of about 500 linear, another and very curious description of these organs present themselves in the form of minute stellate spicula, the rays varying in number from three to ten or twelve, passing off from a common centre in every direction. The radii are gradually attenuated from their basis towards their points, and terminate acutely. These singular spicula abound in every part of the yellow fleshy matter of the sponge, in which they are dispersed without any definite arrangement.

"If a thin slice be taken from the outer surface of the crust of the sponge, and examined as a transparent object with a linear power of about 300 , numerous short fusiform spicula, with very abrupt terminations, will be observed. They are thickly dispersed throughout the whole of the encrusted surface, but without any apparent order of disposition. Upon submitting them to examination with a power of 900 linear, their surfaces were observed to be irregularly tuberculated. These little spicula, from their great abundance in the encrusted surface of the sponge, are justly entitled to be distinguished as the spicula of the crust. They are found occasionally, but comparatively rarely, along with the stellate spicula of the fleshy substance, and they also occur thinly dispersed beneath the surface of the great excurrent canals. I did not succeed in detecting any organization in the epidermal membrane of the crust, probably in consequence of its being obscured by the great abundance of minute spicula immediately beneath its surface; but in the membrane lining the interior of the excurrent canals, there were numerous minute vessels or fibres, disposed in parallel lines in one part of the tissue, while at another spot, they assumed the form of an irregular reticulation. These fibres or vessels are exceedingly minute, and it is requisite that they should be observed with a power of at least 800 linear, and 
then it is only in the clearest and most transparent parts of the nembrane that they are likely to be seen.

"The gemmules of this sponge are dispersed in great abundance throughout every part of its substance ; they are of an oval form, the longest diameter being the $\frac{\pi}{\tau} \tau$, and the shortest the $\frac{1}{9} \frac{1}{4}$ of an inch. They vary considerably in size, but the above is their average dimensions. When seen by direet light with a power of 100 linear, they appear of the same colour as the surrounding fleshy matter, but when viewed as transparent objects, they assume an iron or slate-gray colour, having their surfaces closely studded with minute papillæ, which are produced by the projection of the points of numerous very small spicula, which are imbedded in the crust or shell of the gemmule, and are disposed in lines radiating from the centre to the circumference of its body. The form of these minute spicula is exceedingly various, but the best developed ones appear conical, having their bases towards the centre of the gemmule, and their apices slightly clevating the parts of the onter integument immediately above them. The mode of disposition of these spicula is best observed when a small portion of the sponge has either been treated with boiling nitric acid, or by incineration in the flame of a lamp. The dissolution of the gemmules is not effected by either of these agents; and to view them with the greatest effect, they should be gently triturated with a little water between two pices of glass, until some of them are broken into small pieces. In these fragments, the spicula may be seen in situ, arranged in the manner I have before described, and cemented together apparently by siliceous matter, which appears to abound in the outer integument of the gemmule. Upon measuring some of those minute spicula in situ, I found the arerage leugth to be the $\frac{1}{3} \frac{1}{5} 0$ of an inch, or about equivalent to the diameter of a dise of human blood, and their average diameter the $\frac{1}{3} \frac{1}{5} 75$ of an inch, so that they are of exceeding minuteness, as compared with those found on other parts of the same sponge: the rays of the stellate spicula averaging the of an inch in length, by $\frac{1}{90}$ in diameter, and those of the skeleton, a diameter of about the $12 \frac{1}{50}$ of an inch. In the en- 
crusted surface of this sponge I also observed numerous round siliceous molecules which were dispersed amid the spicula of that part in great abundance. The diameters of these in many cases were equal to that of the surrounding spicula, but the greater number did not exceed the half or a third of that size." -Bowerbank.

In Figure 3 of Plate $V$. are shown the simple and stellate spicula, and the gemmules of this remarkable sponge. A very beantiful drawing of it, and of its parts highly magnified, has been made for Mr Bowerbank, to illustrate a paper which my friend is about to publish. Mr Bowerbank inclines to consider the species as the type of a new genus, - an opinion in which I concur. It may be considered as standing between the genera Halichondria and Geodia, to narrow the gap that kept them so widely asunder. The bodies which Mr Bowerbank has described as the gemmules of its crust are, he writes me, very much alike in structure to the granules of the Geodia, which he finds also occur in the body of this sponge, as well as in the crust. This suggests the query-whether the cuticular granules of Geodia may not be truly gemmules? but I confoss that to me it appears the question should be answered in the negative. Their position, their siliceous and crystalline character, and the mode of their aggregation, seem all opposed to it; and not less so, the difference between them and the recognized gemmules of some Halichondrix. 


\section{PART II. \\ THE \\ BRITISH LITHOPHY'TES.}

Fig. 19.

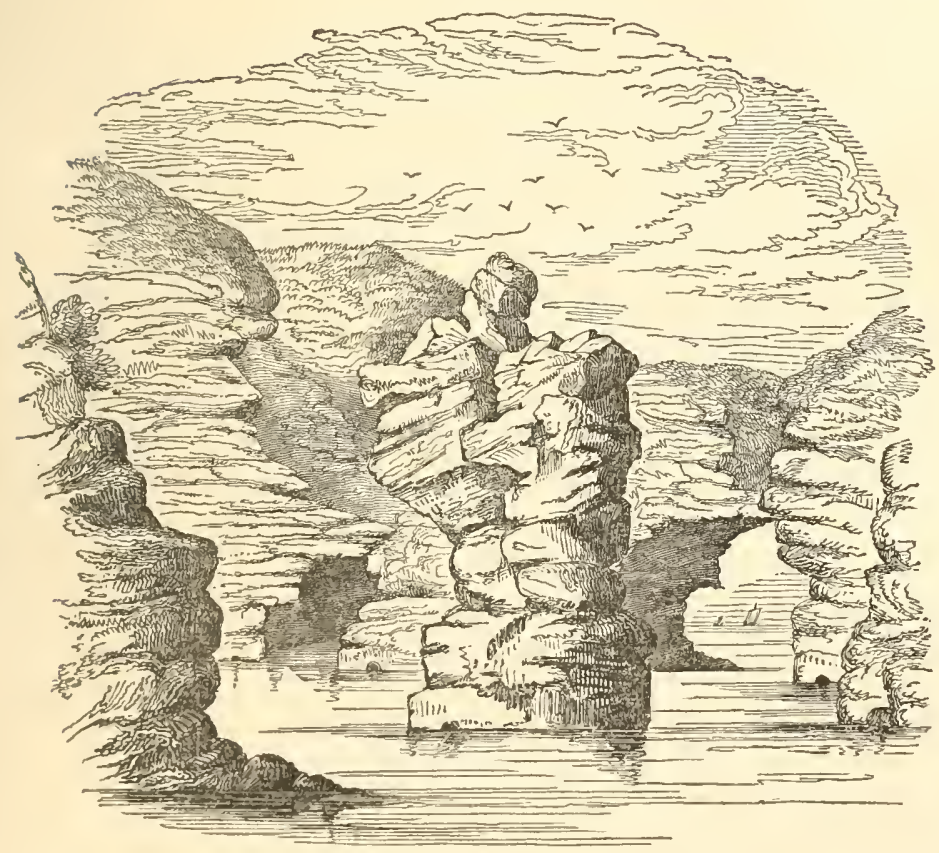

The Doo Coves near Cockburnspatil.

"The picturesque and iron-bound shore!-along which I was wont

to ramble in full enjoyment."-Capt. Busil IIall. 


\section{$\left[\begin{array}{lll}204 & \end{array}\right.$}

"Corallinas ad Regnum Animale pertinere ex substantia earum calcarea constat, cum omnem calcem Animalium esse productum verissimum sit."-Linnaus.

"Mihi vero totum hocce genus Botanicis relinquendum videtur. Nec enim structura, nec chymicis principiis ad Zoophytorum ullum genus accedint, et pleræeque species etiam habitum prorsus peculiarem habent, aliquæ ad Fucos potius accedentes, plurimæ Confervis comparabiles, quamris lapidescenti substantia ab iisdem et omnibus vegetabilibus dis. tinctissimæ."-Pallas.

"Heu, quæ nunc tellus-quæ me æquora possint Accipere?

Cui neque apud Danaos usquam locus."-Virgil. 


\section{$\left[\begin{array}{ll}205 & ]\end{array}\right.$}

\section{SYNOPSIS OF THE GENERA.}

The native Lithophytes may be arranged under two families : viz.

I. Corallinade-Calciferous Algæ with a branched articulated frond.

Frond trichotomous, articulations subcylindric 1. Corallina.

- dichotomous, articulations cylindrical 2. JANIA.

— branched, articulations kidney-shaped HALINEDA.

II. Nuliporide-Amorphous solid calcareous vegetations.

Form variable; structure homogeneous 4. Nuldipoka.

"Order is Nature's beauty, and the way To Order is by rules which Art liath formed."

From the " Duetor," ii. p. 295. 


\section{FAMIILY I.}

CORALLINEA, Lamour. Cor. Flex. 244.

Articelated Coraluises, Ellis. Corall. 45. Corallises, Pall. Elench. 418: Coratisis, Lin. Syst. 1304: Solund. Zooph. 118. Les Corallines, Cuv. Reg. Anim. iii. 305. Cokallide.e, Gray, Brit. Pl. i. 339: Corallixade, Flem. Brit. Anim. 513: Calciphyta ou Corallises. Blaing. Man. 515: Les Corallinisees, Risso, l'Europ. Merid. F. 321: ALg.玉 ceM CALCE Nascestes, Schweig. Beobacht. tab xi. and Handb. 436 : Corallixes, Link. in Ann. des Sc. Nat. n. s. Bot. ii. 326.

\section{Character.}

Frond rooted by a crustaceous basis, ramose, conferroid, contracted at regular interrals so as to appear jointed in a moniliform manner, composed of an interior fibro-membranaceous axis, corered with a crust of carbonate of lime : Fructification-granules contained in tubercles near the extremities or in the axils of the branches.-Marinc. 


\section{THE}

\section{BRITISH CORALLINES.}

The Corallines are marine productions which grow in profusion on rocks, shells, and, more rarely, on sea-weeds, to which they are rooted by means of a spreading calcareous crust; and they rise up, to the height of a few inches at most, in lichenoid or conferra-like tufts, dividing and subdividing, from the base, into numerous branches and branchlets, having the same structure and appearance as the primary shoots. They are remarkably distinguished from other algæ by being covered over with a calcareous crust, which is jointed at short and regular intervals, and conceals a central axis of a decidedly vegetable nature. It has the subcartilaginous texture of sca-weeds in gencral, and, when the tissue is examined microscopically, appcars to be fibrous; and, under a higher magnificr, to be composed of numerous scries of oblong cells arranged in close and intimate parallelism. It is likewise constricted at intervals corresponding with the articulations of the crust; and as the fibrous structure is most evident in these constricted places, so it is also 
very evident that they are unfurnished with that vascular or glandular apparatus by which the lime that invests the internodes is seereted. The erust itself is homogeneous, either smooth and unpunctured, or, as it is asserted of many foreign species, perforated with pores sufficiently large to be visible to the naked cye, but these pores are not the exterior orifices of eells proceeding from the axis, nor indeed have they any intimate communication with it.

The history of the Corallines in respect of their elaims to a registry among regetables or animals is nearly the same as that of all other zoophytes. They were universally believed to be sea-mosses or confervæ, ${ }^{*}$ until Ellis, swayed in this instance by analogy eliefly, demanded their removal to a higher category. "The coralline," he says, "is an animal growing in the form of a plant, whose stem is fixt to other bodies, and is composed of capillary tubes, whose extremities pass through a calcareous crust, and open into pores on the surface." + That we may perceive these pores, it is necessary they should be viewed immediately on the coralline being taken out of the sea, for after it has dried, they are scarcely to be distinguished from a polished superficies "without the help of the very best glasses." + Notwithstanding their minuteness, Ellis had no doubts of these pores being polype-cells, although it does not appear that he was ever able to detect any signs of life in them. Linnæus readily adopted Ellis's opinion, for the corallines coutain a large quantity of lime in their composition, and he

* "Corallina est planta genus in aquis nascens, tenuissime divisum, ex partibus constans articulatione quadan veluti conjunctis." Raii Syu. i. p. 33 .

† Zoophytes, p. 108.

$\ddagger$ Nat. Hist. of Corallines, p. 47. 
was "well-convinced that lime is never produced by vegetables, but by animals only."* In opposition to these high authorities, Pallas considered the aneient right of the botanists to the corallines far from having been disproven, for, al though they did differ from every other plant in their stonyness, yet neither did they make any approaeh to any kind of acknowledged zoophytes. When alive and fresh, they had no mucous and polypiferous incrustation; and their superficial pores were too minute to be the cells of polypes. Jussieu liad accordingly failed to discover any sign of animal life in them; and the fact, now first announced, of there being a terrestrial specics, was a cogent argument against the belief that this would ever be found. Further, Ellis had shown that, at certain seasons, therc appeared on the extremities of corallines certain nodules and tubereles from which some seedlike bodies could be pressed, and as these were somewhat analogous to the fructification found in Fuci and Conferve, the fact afforded an argument in farour of their sameness. $†$

Ellis, in an elaborate essay, immediately answered this reasoning of Pallas, and neutralized its influence. He showed that the evidence for the existenee of a land species was weak and nugatory; + he plcaded that the inability to detcet the polypes was far from proving their absence; and the minuteness of the pores being in correspondency to the size of the filaments which pullulated from them, great difficulty in their detection, or entire failure, might be naturally antieipated, until elianee presented some favourable opportunity, or the discovery of better glasses gave us addition-

* Lin. Corresp. i. p. 208.

$\neq$ On the subject of regetables impregnated with carbonate of lime, mistaken for corals, see a note in Edin. Phil. Juurn. ii. p. 198. 
al power. ${ }^{*}$ He showed, morcover, that the analogy attempted to be drawn between the confervæ and corallines held goorl, according to his idea of them, neither in their mode of growth, their structure, nor fruetification; and that the chemical constitution of the two families was entirely different. $†$

This able essay appears to have satisfied Pallas, and to lave gained him over to the opinion of his opponent; while, perhaps, Ellis was induced to abate something, not of their animality, but of its degree, for, in a subsequent work, he says-" What or where the link is that unites the animal and vegetable kingdoms of nature, no one has yet been able to point out; some of these corallines appear to come the nearest to it of anything that has oecurred to me in all my researches: but then the calcareous covering, though ever so thin, shows us that they cannot be regetables." +

The belief in the animality of corallines prevailed now as generally as did the opposite creed previously to the discoveries of Ellis, nor, for many years, was any addition made to our knowledge of them. Lamouroux tells us, that their polypes are not apparent, $\S$ but of their existence, he seems to have entertained no doubt, for we are afterwards informed that the position of the polypes in sueh species, as are referred to his genus Jania, is, probably, different from their position in the true Corallinæ. In the former, every thing, he says,

* " The minuteness of the pores of Corallines, though as small as those of some plants, is no proof of their being vegetables, because there may be suckers that come through these pores, which our glasses camnot discover; or perhaps they may be like the pores of sponges, contrived in such a manner as to suek in and throw out the water." Zoophytes, p. 109.

+ Phil. Traus. lvii. p. 404, \&e.

$\$$ Zoophytes, p. 108.

$\$$ Corallines, p. 30. 
leads to the presumption that the polypes are placed at the summit of the branches, while in the latter, they apparently cover all the surface of the polypidom under the form of filaments, which, though scarcely retractile, are yet endowed with a movement that can only be attributed to animal life.* "In rambling over the Calvados, (a range of rocks on the coast of Normandy, I have frequently found a very large corallina, a variety of the C. officinalis; it was covered with simple transparent filaments, a millimetre in length, which had a movement peculiar to themselves: they disappeared with the slightest agitation of the water, or when the polypidom was exposed to the air. In the latter case, I was never able, with the strongest magnifier, to discover the slightest remains of those filaments, the point they had been attached to, or the cells they miglit have issued from, supposing them to have been polypi. This, however, remains doubtful, as it was only in spring I ever observed them, and then only on a few particular individuals. I never could discover them in winter." + - Lanouronx has found the tubercles that frequently stud every species of coralline to be solid or filled with small grains, -whence he deems it probable that they are oraria, enclosing the germs of future polypidoms.

Aecording to Bosc, the pores scattered over the coralline are each of them the dwelling of a polype, but he confesses that upon trial he could never see the animal. What else he writes on this subject, is borrowed from Ellis.

Lamarck boasts that to lim belongs the merit of having discovered the true position of the corallines amongst zoophytes, for although Solander had previously approximated

* Corall. Flex, p. 267 : Corall. p. 120.

$\ddagger$ Hist. Nat. des Vers, iii, pp. 70 and 72.

$\dagger$ Corallina, p. 124-5. 
them to the corticated Gorgonia, Antipathes and Isis, yet lic had done so without any apparent motive. Not so with Lamarek. He gave them a precedency to all these generaclassified, nevertheless, in one common order-by showing, that on the one hand, the natural transition to the Milleporcs was made through the medium of the retienlated polypidoms; and, on the other hand, that the Coralline, as true corticiferons polypes, terminate their section, and effect as evident a passage to the "polypiers empâtés" by the Penicillus and Flabellaria. "Ainsi la determination du véritable rang des corallines m'apartient, et serait probablement constateé si l'on pourait conna ître l'organization des polypes qui forment ces polypiers."-Of the existence of thesc polypes, he was perfectly assured, though from their necessary minuteness they had hitherto eluded the sight. They will probably bo found to be organized like the polypes of other corticiferous genera, and must necessarily be placed in the crust, for the axis is not tubular, as Ellis states, but entire, full and continuous like that of the Gorgonir.**

This lypothetical reasoning of his illustrious colleaguc had no influence over De Blainville, who, from his study of living corallines, was confirmed in the belief of their bcing algæ or sea-weeds, as had been ever maintained by Olivi, Spallanzani and Cavolini.† The more extensive experiments and microscopical observations of Professor Sehweigger leave no doubt of the truth of this doctrine, having proved to us that the basis of the corallines has the ecllular structure characteristic of the vegetable tissue but gradually assuming the appearance of a coral from the deposition of lime in its interior. "The deposition of calen-

* Anim. s. Veìt. ii. p. 32.5-328.

+ Mem. de Polipi Marini di Filippo Cavolini, p. 260. 
reous matter in the corallines," lie says, "appears to proceed from the surface inwards. The outer corering is obscrved opaque at particular places, as if incrusted, while the substance within is green throughout, and contains little lime. The calcareous deposition proceeds more and more towards the interior, the green colour and cellular structure disappear, but, at the commencement of this calcifying process, the regetable cellular structure can be quiclily and distinctly reproduced by means of acids. The deposition of lime begins with the very first apperance of the branches; the minutest stallis of the Cor. opuntia were found to contain some lime, the quantity of which increased as the brancles grew."*

The idea of the animality of these bodies may be considered to have been henceforth relinquished. Their nonconformity to other zoophytes, and the absence of polypes in them, was demonstrated; for the dim and dubions signs of them which some previous enquirers had seen were shown to be either the young shoots of parasitical conferra, or the abnormal prolongations of the fibrous axis of the coralline. II ence Blainville removed them from the class of zoophytes to a separate one, which he named "Calcipliytes." + But this example has not been followed by any Britisls naturalist, -and in spite of all evidence to the contrary, the corallines find an incongruous place in our latest Fauna, nor will any of our florists adopt them.t These

" "Obscrvations on the Anatony of the Corallina opuntia, and some other species of Corallines, by P'rofessor Schweigger" in the Edin. New l'hil. Jourual, Vol. i. p. ․2.2; also Edin. Phil. Journ. iii. p. 414.

+ Manual d'Actinologie, p. 545 .

‡ "Let Zoologists keep their eryptogamia,-the regretable kingdom has more than enough," exclaims my friend Dr Grahum, the much re- 
may, perhaps, be now disposed to do so, secing that Link, unhesitatingly arranges them amongst the algx. (They are not, however, ineluded in Mr Harvey's recently published "Manual of the British Algæ." Lond. 1841.) Of the productions formerly referred to the corallines Link makes two families-the Halimedece and Corallinea. Of the former we have only one doubtful native (H. opuntia), and Link's examination of it agrees in general with that of Schweigger, and leaves no doubt of its vegetability, as well as of the whole genera allied to it. Of the Corallineæ, he says, he has found on many individuals very distinet grains or seeds. "When we put the Corallina offieinalis in diluted hydrochloric acid, and leave it there until its lime has been dissolved, we obtain a preparation preserving the original form of the coralline, but it has become of a gelatinous consistenee, and the articulations of the body are very decided. With a moderate magnifier we observe some transverse strix of a reddish colour, composed, as it appears, of a granulous mass. If the magnifier is very powerful we see the granules distinetly, as well as a great number of longitudinal and parallel tubes, of a diffcrent size, which are either empty or filled with granules. These granules separate readily on a slight pressure. All that substance is composed of short, straight cells, placed end to end and immersed in a gelatinous matter. The same structure is found in Cor. rubens, which, in general, differs from Cor. officinalis only in colour, and beeause it remains always softer. In the Cor. rosarium the strueture is somewhat different. There the calcareous matter is greenish; the coral's form is not altered by being steeped in the acid, but it becomes white spected Professor of Botany in the University of Edinburgh. Third Report of the Botanical Society, p. 52. Edin. 1840. 
and of a zelatinous consistence as usual. The granules do not form transverse strice, but we pereeive them heaped up in the articulations. 'Thus they are redder and larger than the preceding, partieularly than the granules of C. offieinalis, and they more distinetly appear to be seminal grains. We ean separate them easily by a light pressure. The tubes are not so regularly parallel in that speeies as in $\mathrm{C}$. officinalis. M. Selnweigger pretends that he found some parallel filaments in C. rubens, but it appears he did not free them sufficiently of their calcarcous crust, so that he speaks with cousiderable uncertainty of their internal organization. He does not distinguish the Halimedex and Corallinea precisely enough in his remarks, and he attributes to both, what evidently belongs only to one of the families. These very obvious seminal grains approximate the eorallines to the Zonaria."

* Ann. des Sciences Nat. Bot. n. s. ii. p. 3:26-7.

Was there a need of adding any additional proof of the vegetability of the Corallines, an experiment now in progress before me would seem to supply it. It is now eight weeks ago since 1 placed in a small grlass far, containing about six ounces of pure sea-water, a tuft of the living Corallina offeinalis, to which were attached two or three minute conferva, and the very young frond of a green Llva, while numerons Rissox, several little muscels and amneides, and a star-tish, were crawling amid the branches. The jar was placed on a table, and was seldom disturbed, though uceasionally looked at ; and at the end of four weeks, the water was found to he still pure, the mollusea and other animals all alive and active, the conferve had grown perceptibly, and the coralline itself bad thrown out some new shoots, an! several additional articulations. light weeks have now elapsed since the experiment was begun,-the water has remained ninclianged,-yet the coralline is growing, and apparently lias lost none of its vitality, but the animals have scusibly decreased in numbers, though many of them continue to be active, and show no dislike to their situation. What can be more conclusive? I need not say that if any animal, or even a sponge, had been so confined, the water would long before this time have been deprived of its oxygen, would have become corrupt and ammonianal, and poisonous to the life of arery iving thing. 


\section{CORALLINA, Lin.}

Corallina, Layour. Cor. Flex. 275 : Grax, Br. Pl. i. $339=$ Flem. Brit. Anim. 514: Blainv. Man. 547.-Les Corallines propres, Cur. Reg. Anim. iii. 305.

Character. Frond branched in a trichotomous man.ner, corticiferous; the crust calcareous, homogeneous, unporous, articulated at short and regular intervals; the axis subcartilaginous, solid, constricted at interwals corresponding to the articulations of the crust : Fructification -oblong seminiferous gramules containcd in capsular swellings produced on the extremities or in the axils of the branchlets.

1. C. OFFICINALIs, "the short lateral shoots of the branches rounded, and blunt or capitate."

\section{Plate XIII.}

Corallina anglica, Ger. Herb. 1572. Merrct, Pin. 30. Raii, Hist. i. 65 . Syn. 33, no. i._C. alba sive muscus marinns, Mer. Pin. 30. Muscus corallinus albus et purpurens, Sib. Scot. Ill. ii. lib. iv. 55. Coralline of the shops, Ellis, Corall. 48,-no 2, pl. 24, fig. $a, A, B$. Corallina officinalis, Lin. Syst. edit. x. 805. Pall. Elench. 422. Lin. Syst. 1304. Ellis in Phil. Trans. 1vii. 419, pl. 17, fig. 12, 13. Lin. Corres]. i. 201. Soland. Zooph. 118, pl. 23, fig. 14, 
15. Esper, Corall. tab. 3. Berk. Syn. i. 211. Jameson in Wern. Mem. i. 563. Turt. Gmel. iv. 671. Turt. Br. Faun. 211. Stew. Elem. ii. 439. Cuv. Reg. Anim. iii. 305. La. mour. Cor. Flex. 283. Corall. 127. Lam. Anim. s. vert. ii. 328 : 2de edit. ii. 513. Bosc, Vers, iii. 77. Hogg's Stockton, 38. Flem. Brit. Anim. 514. Loudon's Mag. Nat. Hist. i. 278, fig. 148, d. Graut in Edin. Phil. Journ. xiv. 183. Edin. New Phil. Journ. i. 222. Johnston in Trans. Newc. Soc. ii. 271. Stark, Elem. ii. 426, pl. 8, fig. 4. Risso, L'Europe. Merid. v. 323. Gray, Brit. Pl. i. 339. Templeton in Mag. Nat. Hist. ix. 469. Blainv. Actinol. 547, pl. 96, fig. 3, 3 a. Krauss, Corall. et Zoophyt. der Sudsee, 14. Delle Chiaie, Anim. s. vert. Nap. iv. 148. Schreeig. Handb. 437. J. B. Harvey in Charles. worth's Mag. Nat. Hist. ii. 512. Bellamy's S. Devon, 267.

Corallina laxa, Lam. Anim. s. Vert. ij. 328: 2de edit. ii. 514.

Corallina Calvadosii? Lamour. Cor. Flex. 290. Corall. 131. Lamour. Soland. Zooph. 25. Delle Chiaie, Anim. s. Vert. Nap. iv. 149 .

\section{Primary or Crustaceous State.}

Corallina membranacea, Esper Corall. tab. 12.

Nillepora miniacea, Esper Millep tab. 17. Fig. 1-4.

Millepora fucorum, Esper Millep. tab. 23, fig. 1-4.

Melobesia pustulata et M. farinosa, Lamour. Cor. Flex. 315, pl. 12, fig. 2, 3. Corall. 142, pl. 12, fig. 2, 3.

Melobcsia membranacea, Lamour. Cor. Flex. 315. Corall. 142. Schweig. Handb. 438.

Corallium lichenoides, Ellis in Phil. Trans. lvii. 419, pl. 17, fig. 9-11.

Millepora lichenoides. Borl. Cornw. 239, pl. 24, fig. 2, 3, 5. So. land. Zoopls. 131, pl. 23, fig. 10-12. Flem. Brit. Aum. 528. Hassall in Ann. Nat. Hist. Nov. 1840, 174 and 236. Bellamy's S. Devon, 269.

Chalky coral, shaped like liverwort, Ellis, Corall. 76, no. 2, pl. 27, Fig. $d, \mathrm{D}$.

Millepora alga, Turt. Gmel. iv. 639. Turt. Brit. Faun. 205. Stew. Elcm. ii. 4:28. Bose, Vers, ii. 344.

Millepora foliacea, Risso, L'Europ. Merid. v. 350.

Corallina auriculurixformis, Sowerby, Brit. Misr. 119, pl. 56 . Turt. Brit. Faun. 211.

Millepora polymorpha, Johnston in Trans. New. Soc. ii. 271.

Nullipora lichenoides, Templeton in Loudon's Mag. Nat. Ilist. ix. 470. 
Mab. On rocks and shells between tide-marks, profusely on every part of the British coast.

Coralline affixed by a spreading calcareous base, from one to four inches in height, of a dull purplish colour when recent, bushy, the primary branches irregular, erect, the secondary plumose, pinnate or bipinnate ; joints cylindrical or wedge-shaped and somewhat compressed, sometimes twice as long as their diameter, and sometimes not more than equal to it, smooth or blistered; the shoots sprout from each shoulder of the joints, and the young shoots have usually long, slender, cylindrical joints, while those which terminate the branches are either tipped with a little white globular or ovoid tubercular enlargement, or with a row of little white tubercles, arranged in a palmate fashion.

This description has been derived from what seem to be normal specimens taken from pools of clear water in the rocks of our shore, whose sides they adorn with their tufted frirges, hanging over each other, in the same plumy manner that the Hypna do over the shclving banks of our deans. But on every shore, specimens of the coralline may be gathered which deviate so much from the normal character, and from each other, as to render a general description almost nugatory. " Pro xtate atque rigore insigniter, et crassitie et elegantia ac forma, rariat hæc corallina, unde multiplicatre Ellisii species, quas intermerii gradus, in eademque sape stripe structuræ extrema occurrentia conjungunt." Pallas.

The branches are sometimes partially studded over with smooth conoid tubercles, either sessile or raised on a cylindrical pedicle. The extremities of the branches are usually terminated with analogous tubercles in the spring season, and from these, after they had been steeped in vinegar, which rendered the whole soft, Ellis squeezed out "little twisted figures," which he has figmed with his usual accuracy. I found these capsules, as I 
believe them to be, coloured like the coralline itself. After they have escaped naturally, the tubercles exhibit a small opening on their top and become hollow. I have in vain sought for these seminiferous capsules in the winter months.

The Corallina officinalis, after death, or after being detached and cast on shore, speedily loses its claret colour, facles to a pale pink, and in a few days becomes entirely white. These changes take place with greater rapidity when the specimen is immersed in fresh water, for then the depth of its colour becomes almost. instantly weakened. It retains the colour unchanged, on the contrary, in a weak acid, which, however, soon removes the calcareous crust, and then the specimen bears a close resemblance to some of the articulated Fuci. When the coralline is now examined, it is found that the form and integrity of the specimen have remained unaltered. The axis exhibits the same articulated appearance as the crust had done, but the joints are merely constrictions in its calibre, deprived of the colouring matter of the internodes, and do not intermpt its continuity. These strictured portions are decidedly fibrous, the fibres parallel and numerous, but which become obscure or lose themselves in the internodes. These may be also fibrous, but the structure is not easily made out. Under a magnifier, they appear to be solid, and to be composed of cells exhibiting an areolar or netted structure, the interstices filled more or less with minute granules, and a set of vessels runs through it, anastomosing on the apices of the extreme joints. This strueture is best secn when the specimen has been allowed to dry on a plate of glass; but it must be confessed that the appearances are by no means umiform. The figure which I have given in Pl. XXII. Fig. 6, represents very exactly what was seen in one carefully prepared specimen.

"When a small living branch of the Corallina officinalis is placed under the microscope with sea-water, we obscrve the rounded extremity of each of the last digitations tipt with a thiu 
layer of a soft, transparent, colourless matter ; this transparent covering is spread completely over the free ends of all the branches, is thickest in the centre, and tapers gradually to the sides, where no trace of it is seen; on the surface of this matter we can distinguish very minute tubercles or papillæ, likewise tramsparent, but which do not appear to have any motion. I liave not observed this on any other part of the coralline; and, as it appears to have escaped notice, and may possibly have some connection with the mode of growth of a substance whose nature is still perfectly unknown, I have thought it worthy of being suggested to the attention of zoologists." $D$, Grant.

Cor. officinalis appears first in the guise of a thin, circular, calcareous patch of a purplish colour, and in this state is common on almost every object that grows between tide-marks. When developing on the leaves of Zostera, or in other unfavourable sites, these patches are usually pulverulent and ill-coloured, green or white, and never become large ; but, in suitable situations, they continue enlarging in concentric circles, each marked with a pale zone, until they ultimately cover a space of several inches in diameter. The resemblance which, in this condition, the crust has to some crustaccous fungi, more especially to the Polyporous versicolor, is remarkably cxact, and neither is it less variable than the fungus in its growth, the variations depending on the nature of the site from which it grows. If this is smooth and even, the foliaceous coralline is entirely adnate and also even, but if the surface of the site is uneven or knobbed, the coralline assumes the same character. If it grows from the edge of a rock, or on the frond of a narrow sca-weed, or from the branch of the perfect coralline, the basal laminæ spread beyond in overlapping imbrications of considerable neatness and beauty : they are semicircular, wavy, either smooth or studded with scattered granules, and these granules may be either solid or perforated on the top. Such states of the coralline have been de- 
scribed as Millepora lichenoides; while its eariier states constitute Lamouroux's various species of Melobesia.*

Mr J. B. Harvey says-" An intelligent friend, $\mathrm{Mr}$ Burnett, lately directed my attention to the very beautiful white light produced by holding pieces of $\mathrm{C}$. officinalis close to the flame of a candle." In making the experiment, the coralline must be held close to the flame but not in it.

Cor. officinalis was once believed to possess very powerful vermifuge properties. "Corallinæ crassiusculæ contritæ pulvis in vino, lacte aut cassia exhibitus, pueris ad drachmam dimidiam, adultioribus ad drachmam unam interaneorum vermes enecat et expellit." Ray.

2. C. ELONGATA, the lateral shoots of the branches slonder and subulate, with long cylindrical articulations.

Slender trailing English Coralline, Ellis, Corall. 48, pl. 24, fig. no. 3. Corallina elongata, Ellis and Soland. Zooph. 119. Turt. Gmel. is. 671. Turt. Br. Fann. 211. Stew. Elem. ii. 489. Lamour. Cor. Flex. 285. Corall. 128. Gray, Br. Pl. i. 340. Bosc, Vers, iii. 76. Risso, l'Europe Merid. v. 322. Blainv. Actinol. 547. Corallina longicaulis, Lam. Anim. s. Vert. ii. 329 : 2 de edit ii. 514.

Hab. Coast of Cornwall, Ellis. Jersey, A. H. Hassall.

Coralline attached by a crustaceous base, rising to the height of three or four inches, very bushy, distinctly jointed, slender, the ultimate branchlets almost hair-like : articulations of the stem not much longer than their own diameter, somewliat compressed and wedge-shaped, the shoulders often produced into a spirule: articulations of the setiform pinnules cylindrical, from two to six times their diameter in length, often terminated with a grani-

- Melomia flegans of Bean is, however, a very different thing. $I$ believe it to be a polythalamous zoophyte, and that its right place will be among the Polysomatia of Ehrenberg. It is described and figured by my friend A. I1. Hassall in the Annals of Nat. Ilistory for Nov. 184P, p. 173, pl. 7, fig. 2. 
ferous tubercle, which frequently becomes axillary by little setaceous branches shooting up from each side.

This coralline, Ellis says, "is remarkably slenderer, longer, and smaller than the officinal coralline, and of a reddish or purplish colour." Even after it had been reduced to a variety of the C. officinalis by Linnæus and Pallas, Ellis still retained his opinion of their specifical distinctness, and after some hesitation, and a comparison of specimens before me, I have been induced to follow the same course,-principally from the great difference in their habit or general appearance, which a specific character cannot be made to express. The crust is smooth and unporous. In its mode of producing granules the species resembles the rariety cristata of Jania rubens; and it is curious to remark that the setiform side branchlets have the slenderness and long cylindrical articulations more peculiarly characteristic of the genus Jania.

3. C. Souamata, "the short lateral shoots of the branches compressed and two-edged."

Upright English Coralline, with spear-like heads and flat joints, Ellis, Corall. 49, No. 4, pl. 24, fig. c, C.

Corallina squamata, Ellis and Suland, Zooph. 117. Turt. Gmel. iv. 671. Turt. Br. Faun. 211. Stcu. Elem. ii. 439. Lamour. Cor. Flex. 287. Corall. 129. Lam. Anim. s. Vert. ii. 329 ; 2 le edit. ii. 514. Gray, Brit Pl. i. 340. Flem. Brit. Anim. 515. Bosc, Vers. iii. 75. Risso, L'Europ. Merid. v. 321. Stark, Elem. ii. 426, pl. 8, fig. 5. Krauss, Corall. et Zoophyt. der Sudsee, 17.

C. officinalis, $\beta, \operatorname{Lin}$. Syst. 1304 .

Hab. Coast of Cornwall, Borlase.

"This is of a sea-green colour, and was collected on the coast of Cornwall by the Rev. Dr William Borlase. It has a very different appearance from the officinal Coralline, of which some authors who have not seen it would make it a variety." Ellis.

Smaller and more delicate than the $\mathrm{C}$. officinalis with which 
it has undoubtedly no specific affinity. The joints of the stem and main branches are more distinctly wedge-shaped, and broader in proportion to their diameter, often produced at the shoulders into a spine or short process. They vary a good deal in their lengths, the lowermost being shorter than their own diameter while the superior are in general twice as long. The branches are erect, prettily pinnated with the lateral shoots, the joints of which are rather long, ovate-lanceolate or linear and pointed, with many intermediate forms, but always compressed and brought to a sharp edge usually on both sides, sometimes on one only. Ellis' figure is truly excellent.

The muscologist will trace a resemblance between this coralline and his favourite Dicranum byroides ; and we find a pleasure in remarking, that its form is reproduced in the Australasian seas, where it is represented by the Cor. Cuvieri of Lamouroux. The Cor. 'Turneri of the same naturalist, and from the same distant shores, imitates very closely our Cor. elongata. 


\section{JANIA, Lamouroux.}

Jania, Lamour. Cor. Flex. 266. Gray, Brit. Pl. i. 339. Flem. Brit. Anim. 514. Bualnv. Man. 549.-Les Janies, Cuv, Reg. Anim. iii. 306._Corallinæ pars, Lin._Soland._LaM.

Character. Frond slender, branched in a dichotomous manner; the joints cylindrical ; the crust calcareons, unporous; the axis subcartilaginous, solid, constricted at intervals corresponding to the articulations of the crust. Fructification-Capsular swellinys produced in the axits of the branches containing seminul granules.

1. J. RUBENS, cespitose, joints of the principal branches rylindrical, unarmed.

\section{Plate XXIII.}

Corallinæe aflinis sive muscus marinus tenui capillo, Raii, Hist. Pl. i. 66 .

Corallina rubens, Lin. Syst. 1304. Berk. Syn. i. 215. Krauss, Corall. et Zoophyt. der Sudsee, 14. Delle Chiaie, Anim. s. Vert. Nap. iv. 149.

Jania rubens, Lamour. Cor. Flex. 272. Corall. 122. Gray, Brit. Pl. i. 339. Flem. Br. Anim. 514. Bluinv. Actinol. 549. Bellumy's S. Devon, 267.

Var. $\propto$. Branches cylindrical, straight, virgate, Cor. rubens, I'all. Elench. $\$ 26$. 
Fig. 20.

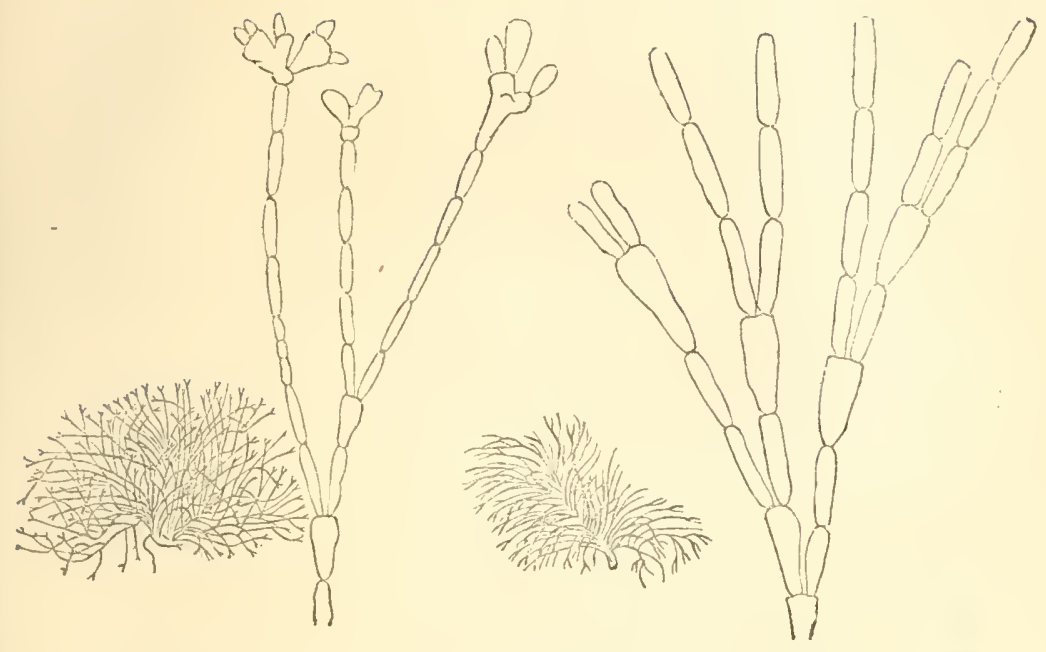

Tar. B. Branches cylindrical, straight, the ultimate divisions with bifid or trifid summits. - Cor. muscosa, Plunk. Phytog. pl. 168, fig. 3.

Corallina capillaceo multifido folio albido, Raii, Syn. i. 34.

Reddish hair-like Coralline, Ellis, Corall. 50, no. 5. pl. 24, fig. $e$, E. Phil. Trans. abridg. xi. pl. 5, fig. 1, 2, 4.

Corallina rubens, Ellis and Soland. Zooph. 123. Turt. Gmel. iv. 672. Turt. Br. Faun. 211. Stew. Elem. ii. 439. Lam. Anim. s. Vert. ii. 332: 2de edit. ii. 517. Risso, L'Europ. Merid. v. 323. Hogg's Stockton, 38. Bosc, Yers, iii. 77. Stark, Elem. ii. 426, pl. 8, fig. 6. Edin. New Phil. Journ. i. 222.

Jania rubens, Templeton in Mag. Nat. Hist. ix. 469.

Var. 2 . Branches divaricate, with tubercles in the axils of the upper divisions. (Woodeut, no. 21.)

Corallina muscosa sive muscus marinus tenui capillo spermophoros, Morrison, Plant. Hist. Ox. iii. 651, tab. 9, fig. 9.

Muscus coralloides ramossissimus polyspermus, Raï, Syn. 33, No. 2. C'rested or Cock's-comb Coralline, Ellis, Corall. 51, no. 7, pl. 24. fig. $f, F$.

Seed-bearing Coralline, Ellis, Corall. 51, no. 8, pl. 24, fig. $g$, $G$. Corallina eristata, I'all. Elench. 425. Ellis and Soland. Zooph. 121. Turt. Gmel, iv. 672. Turt. Br. laun. 212. Stew. Elem. ii. 440. Lam. Anim. s. Vert. ii. 33:3 : 2de edit. ii. 518. Bosc, 
Fig. 21.

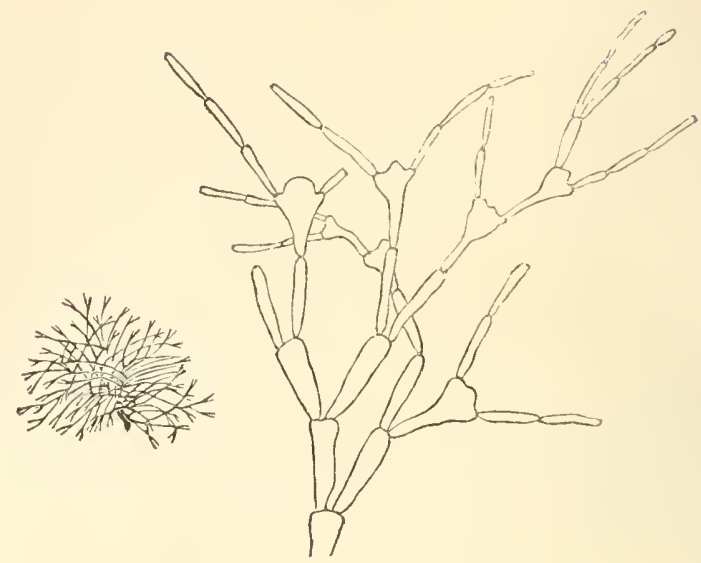

Vers, iii. 77. Risso, l'Europ. Merid. v. 324. Stark, Elem. ii. 426.

Corallina spermophoros, Ellis and Soland. Zooph. 122. Esper, Corall. tab. 10. Turt. Gmel. iv. 672. Turt. Br. Faun. 212. Stew. Elem. ii. 440. Lam. Anim. s. Vert. ii. 332 : 2de edit. ii.

517. Bosc, Vers, iii. 78. Risso, lib. cit. 324.

Jania spermophoros, Templeton in Mag. Nat. Hist. ix. 469.

Var. $\delta$. The young state: simple or slightly forked, with cylindrical joints proceeding from a spherical globule.- Snow-white downy coralline, Ellis, Corall. 52, no. 9, pl. 24, fig. $h, H$.

Curallina globifera, Turt. Brit. Faun. 212.

$H a b$. Grows generally on the smaller algæ. It appears to be very common on the southern coasts of England, and, according to Mr Bean, is not uncommon at Scarborough, but we do not find it on the coast of Berwickshire, and it is certainly rare on the eastern shores of Scotland. It occurs commonly enough on the west coast; and is abundant on the fruitful shores of Ireland.

Grows in dense tufts from half an inch to two inches in height ; generally of a pale-purplish or pink colour, said to be often white, and occasionally green, much branched dichotomously, the branches slender, filiform, jointed, with articulations from four to six times longer than their diameter. They 
are generally smooth and ever, but sometimes the crust is blistered or raised into small nodules. In the axils of the - branches there are often found calcareous tubercles which are undoubtedly the seminal capsules. Some of these, after the calcareous matter has been removed by an acid, may be seen to contain a single blackish grain invested with a membranous bladder; while others, probably more $\mathrm{m}$ ture, contain several of an irregular shape, and arranged in an obscure spiral fashion.

The structure of the axis is decidedly regetable, and rery similar to that of Corallina officinalis, but the reticulation of the internodes is more regular, and the meshes are oblong. I did not discover any ressels permeating the interior, but the constricted portions are colourless and fibrous.

2. J. CORNICULATA, "summits of the lower joints of the stem sub-compressed and produced on each side."

White slender-jointed Coralline, Ellis, Corall. 50, no. 6, pl. 24, fig. $d, D$.

Corallina corniculata, $L$ in. Syst. edit. x. 806. Pall. Elench. 424. Lin. Syst. 1305. Ellis and Soland. Zooph. 121. Berk. Syn. i. 215. Turt. Gmel. iv. 672. Turt. Br. Faun. 212. Stew. Elem. ii. 440. Lam. Anim. s. Vert. ii. 332; 2 de edit. ii. 517. Risso, l'Europ. Merid. v. 323. Bosc, Vers, iii. 78. Hogg's Stock. 38.

Jania corniculata, Lamour. Cor. Flex. 274. Corall. 123. Gray, Brit. Pl. i. 339. Flem. Brit. Anim. 514. Bellamy's S, Devon, 267.

Hab. Parasitical on sea-weeds. Found in plenty in Cornwall, Ellis.

" This coralline is dichotomous; the joints of the stems have two horns; those of the small branches are roundish." "I have lately examined some specimens of this coralline from Cornwall, and have found that they bear the same kind of ovaries at the angles of their upper divisions in the same manner with the two following species (viz. Cor. cristata et spermophoros); so that it may be a variety of them, or perhaps one of them in another state of growth." Ellis. 


\section{HALIMEDA, Lamouroux.}

Halimeda, Lanour. Cor. Flex. 302. Fles. Brit. Anim. 51.5. Schwerg. Handb. 437.-Flabellaria, Lam. Anim. s. Vert. ii. 342. Blainv. Man. 550.-Corallinæ pars, Lin. Soland.

Character. Coralline plant-like, branched trichotomously, fan-shaped, the branches jointed, very much compressed: crust thin and calcareous; axis flurous.

According to Link Halimeda is the type of a family of corallines which he names Halimedece. He says that when these bodies are deprived of their calcareous crust, they exhibit a lamellated or membranous structure; and no trace of polypes is discoverable even at those points where analogy would lead us to look for them. The crust is friable like chalk, and it is sometimes found on the inner surface as well as on the exterior. All the genera of the family have much the same structure. The genus Flabellaria of Lamarck embraces properly two genera,- the Udotea of Lamouroux and his Halimeda. The latter is jointed, with flattened articulations, calcareous interior$l y$, and filled with a fibrous pith by means of which the articnlations are threaded together. The Halimeda opuntia has been examined very carefully, and in a fresh state, by M. Schweigger. By the aid of the microscope, he ascertained that the 
fibres were sncculent filaments, which crossed and branched irregularly. M. Schweigger adds, that the structure of the cellular tissue is decisive of the vegetability of this coralline. Its parenchyma is formed of vesicular pentagonal or hexagonal cells, a structure similar to that in plants, but which has not been observed in any animal. Link has himself examined the H. opuntia, and his observations agree in general with those of Schweigger, but, using a higher magnifier, he has perceived that the fibrous tissue forming the middle layer of the articulations and uniting them together, is entirely composed of branched leaflets, as in the Laver or Ulva. These leaflets form a membrane which receives the vesicular cells, for the cells, which are rarely angular, are not in contact, and consequently do not constitute the membrane that contains them. The contrary being the fact in plants of a higher order, the Halineda has no affinity to them, but its structure approaches that of the Algæ so near as to entitle us to say, that the Halimeder are compound ulvæ, in the same way that the Fuci may be considered to be compound Confervæ. The calcareous deposition is effected in the cells in the interior of the coralline, or on the two surfaces of the innermost layer. $\operatorname{Link}$ in Ann. des Sc. Nat. 1. s. part. Bot. ii. p. 322 .

1. H. opuntia, "branches trichotomously divided, the joints waved on the margin, and kidney-shaped."

Corallina opuntioides minor, Petiv. Pterogr. tab. 20, fig. 19.

Articulated Coralline of Jamaica, Ellis, Corali. 53, pl. 25, fig. $b$, $B, B, 1$.

Corallina opuntia, Pall. Elench. 420. Lin. Syst. 1304. Ellis and Soland. Zooph. 110, pl. 20. fig. b. Esper, Corall. tab. ]. Bosc, Vers, ii. 73. Schweig. Beobacht. 43, tab. iii. fig. 20-24; and tab. viii. tig. 73. Edin. Phil. Journ. i. 220.

Flabellaria opuntia, Lam. Anim. s. Vert. ii. 345 : 2de edit. ii. 528. Blainv. Actinol. 551, pl. 65, fig. 4. Thompson in Ams. Nat. Hist. v. 254 . 
Halimeda opuntia, Lamour. Cor. Flex. 308. Corall. 139. Flem. Brit. Anim. 515. Schweig. IIandb. 437.

Codium opuntia, Spreng. Syst. Veg. iv. 366.

Hab. "This species has not hitherto been recorded as a British zoophyte, but is said to inhabit the Atlantic and Mediterranean. I, however, possess a specimen, formerly belonging to the late Dr Walker, to which the following note was annexed, in his own handwriting : "Submarine plant fron the rocks at Salterness, in Kirkbane. An Bombycina? It covers the rocks with a close turf.' It thus appears to be a native of the shores of the Solway Firth. When a joint was macerated in weak acid, the branched tubes supporting the polypi appeared as they are represented by Ellis." Rev.D, Fleming.__ "A specimen of this Flabellaria in Mr R. Ball's collection, was found some years ago by $\mathrm{Mr}^{*}$ William Todhunter, among the refuse of a Torbay (Devonshire) fishing-boat, in Dublin bay; it was brought up in the trawl-net somewhere between these two ports." Wm. Thompson.

Fiz. 22.

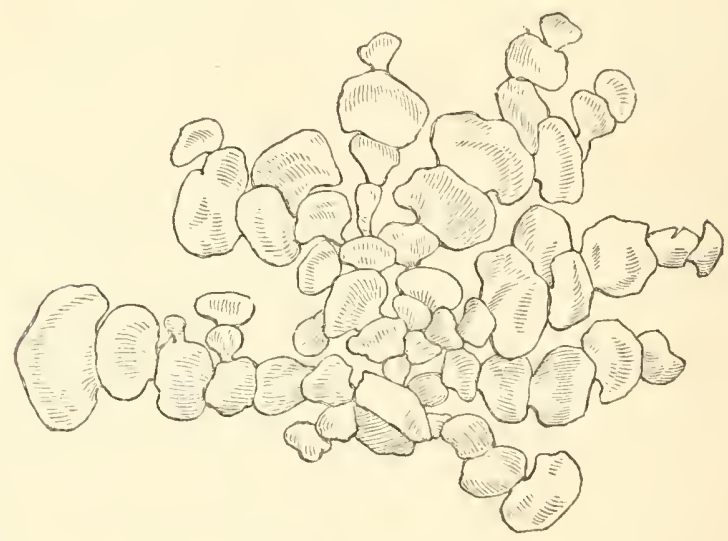

Halimeda opuntia. 


\section{[ 231 ]}

\section{FAMILY II.}

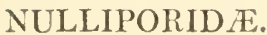

Corallium, Raii, Syn. 32.-Mrleeporx solidiuscula, Pall. Elench. 238. - Millepor E Pars, Lin. Syst. 1282.-Millepores that are almost solid, Soland. Zooph. 129.-Nullipores, Lam. Anim. s. Vert. ii. 203. Blainv. Man. 603.-Lithophyta nUllipora, Schweig. Handb. 412.-Nullipona, Bosc, Vers, ii. 337. Millepora, Flem. Brit. Anim. 528.

\section{Character.}

Calcareous solid bodies of various forms, often lobed or sinuous, even or mammillated on the surface, increasing by the apposition of concentric layers, without any polype cells or cellular structure.-Marine.

« Gelatina animalis omnino lapidesceus. Stirps irregularis calcarea, minime porosa."-Schweigger. 
"Nous voyons par là combien la distance entre les plantes et les animaux est faible. La substance animale est pour ainsi dire opposée à la substance végétale : la premiere disparait dans les Eponges, et la substance végétale y reste; dans les Polypiers communs, au contraire, c'est la substance végétale qui disparait tandis que la substance animale persiste et se développe. Je dois encore ajoutez anx remarques que je viens de faire et qui avaient pour but de faire rapporter plusieurs corps qu'on regardait comme des Zoophytes, parmi les plantes, une autre observation dont le but est de rendre au règne minéral, plusieurs corps qu'on regarde également comme des Zoophytes. Je reux parler des Nullipores." Link.

Fig. 23.

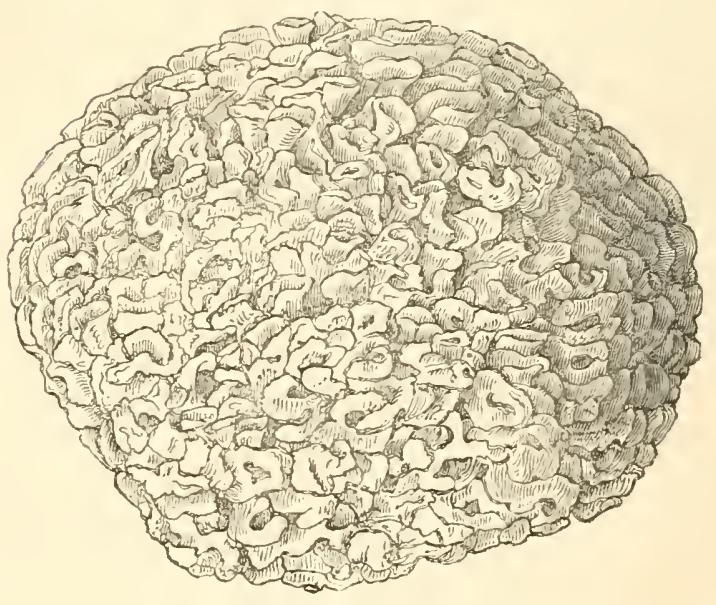

Nullipona agaricitormle. 


\section{BRITISH NULLIPORES.}

'THE opinions of naturalists as to the nature of these productions have ercr been unsettled. Ellis by showing that, when highly magnificd, they appeared to be "full of small pores," evidently believed that he had at the same time demonstrated their polypous origin. Pallas confesses that he could not find the pores, although he had carefully sought for them; yet he deemed it to be scarcely credible that these productions could be mere stony zoophytes destitute of every soft organ or integument. Hence lie was led to susspect that when the Nullipores were alive in the sea, the surface was covered with a certain animal coat or periosteum. Schlosser had indeed informed him that no trace of any such coat could be discovered on recent specimens dredged up in Falmouth harbour; but, adopting a groundless suggestion of Sir Hans Sloanc's, Pallas met this objection to his hypothesis, by expressing a belief that the Nullipore was not a native of that harbour, but had been brought thither, by the force of the tides and winds, from the American ocean. Olivi has, however, since confirmed Schlosscr's observation. 
The opinion of Ellis was then adopted by all naturalists; and even when Lamarck proposed to separate the Nullipores from the true Millepores, he did not entertain any doubt of their polypiferous character. Schweigger, in 1819, was perhaps the first who gave distinct expression to his doubts of this creed.* When in fact we compare the structure of these presumed polypidoms with any undisputed millepore, the difference is at once seen to be very considerable ; for pores can always be perceived on the surface of the latter, and the interior is distinctly cellular, while neither on the surface nor in the interior are there any traces of cells in the Nullipores. These, on the contrary, consist of solid concentric layers of cretaceous matter laid over each other very much in the manner they are in the stalactite. Their apolypous character may indeed be considered as proven. It is very true that they contain a certain quantity of organic matter, but this, according to Blainville, may be deposited simultaneously with the calcareous ingredients, and so incorporated into the mass. 'Thus, then, in De Blainville's opinion, the Nullipores are a kind of staligmites deposited in places where the sea is not liable to be frequently agitated, and where its bottom and banks are formed of calcareous rocks. Such was the doctrine taught long before by Borlase, in his Natural History of Cornwall; and Olivi was likewise disposed to concur in this mechanical explanation of their origin. It has been also adopted by Link, the celebiated Professor of Botany at Berlin. He says-" Olivi and Bertoloni think that the

" Schweigger's definition of his genus Nullipore is_-" Stirps irregu. laris e gelatina animali prorsus lapidescente. Polypi nulli." Handb. 1. 412 . 
Nullipores are calcareous deposites. Schweigger considers them to be zoophytes which bccome calcareous immediately after their birth. As a proof of his.opinion he tells us that after having put the Nullipores into hydrochloric acid, there still remained a gelatino : hw $l_{v}$ with the original form of the Nullipores. I have never found this to be the case, althongh I have dissolved a very great number of Nullipures; all that remained was reduced to some membranous morsels contained in the under part y which the Nullipore had been attached. These morsels, moreover, appeared different from the gelatinous membranes o'tained aftur dissolving the true eorals; and we do not obtain them from fragments of the Nullipores if broken from ne the edge. All the Nullipores I have broken have had some cavities which penetrated pretty deep into the branches, and have exlibited a structure very similar to the Osteocolla or calcareuts tuffa which is deposited upon rushes and other plants in lakes and stanks. In my opinion the Nullipores are nothing else than a similar calcareous deposit formed upon marine plants." Link in Ann. des Sc. Nat. n. s. part. bot. ii. p. 330-31.

To this explanation of the origin of the Nullipores I cannot bring myself to assent. On dissolving several Nullipores in weak acids I found, as Sehweigger had done, that a subgelatinous base remained retaining the form of the original, and exhibiting a very distinet cellular structure, exactly indeed the same in lind as that presented to us by the Corallines. The solution of others, referable to N. polymorpha, destroyed the figure, and left behind merely fragments of membrane, but the transition from the one kind into the other is so gradual, that I cannot suppuse their origin to be the result of two different causes. On the mechanical theory it seems also difficult to account for the 
vivid and varied colours of many Nullipores, which retain their liues only while they remain submerged, and become, white by exposure and bleaching. Some Nullipores are purplish, others green, and others variegated, and the colour is evidently primitive, and not derived from any subsequent tincture. Neither can we account in this way for their forms, for although very inconstant to any one type, yet the Nullipores often shoot up in shrubby figures dependant on no foreign props; or they form globular masses made up of sinuous folded laminæ, which are too regular to be built up from the unregulated sediment of agglutinated particles of lime.

I believe that the Nullipores are endowed with life, and with a vegetative growth, but that they are not species. They are, to my conviction, merely the calcareous basis of Corallina officinalis modified by external circumstances, aud hindered from passing through the stages of its normal developement. This conclusion, which rests on many observations, I do not mean to support by instancing similar arrests of growth in many Fungi, but these afford an apt illustration of my meaning. When an agaric has germinated under pressure, we know well that it will continue to grow vigorously, but the result is a Rhizomorpha or a Himantia,_a woody reticulated, or a plumy fibrous, fungus ! Under other circumstances, the agaric will stop without developing a pileus; and otherwise assume forms so odd, that the parentage can only be guessed at. So with the diffusive Corallina. When its shoots are torn off by the waves, the base, continuing to live, grows thicker and becomes studded with rounded knobs, whence one form of Nullipora polymorpha : when its site is a soft calcareous rock, the basal portion often becomes amorphous and very thick without 
even showing a disposition to throw up any shoots: when germinating in deep water, the growth is likewise arrested and we have lobed or sinuous masses of different densities and figures, deriving their peculiarities from those of the ground they grow upon, and from the state of the water above and around them; and if the coralline has begun its growth on a flat rock where it lies much uncovered by the tide, and open to the sun's influence, it remains for cver a comparatively soft white porous leprous crust,- the Millepora coriacea of some authors. The life of the coralline is too retentive to be destroyed by these influences, and it evidences its continued existence by efforts which result in bastard monstrosities,

Schweigger asserts that he bas traced the Ulva squamaria of Gmelin passing into the Millepora coriacea of Linnæus. (Beobacht. p. 46-7, tab. 4, fig. 25-30: Handb. p. 438.) The figure which he bas given of the Ulva seems to me to represent very well the Zonaria deusta or Podina deusta of British botanists, the true position of which has puzzled the most learned algologists. It is, says the Hon. Mr Harvey, "a very anomalous plant, of very uncertain affinities. I leave it in Padina merely because it has been placed there by others, and that I know not to what other genus it is more nearly allied. Its resemblance to Padina is, however, merely superficial; its structure is totally distinet, and is not even dictyoteous." (Man. Brit. Alg. P. 31.) The observations of M. Schweigger throw light on this question; and those which I have made on the Zonaria, where it grows abundantly on the slaty rocks in front of the coves of Holy Island, have led me to think that the opinion of Schweigger is very probably true. The Zonaria and a erustaceous Millepore, evidently identical with the M. coriacea of Schweigger, grow there intermingled, similar in babit and mode of growth, and with a similar vegetable basis; but although 1 have found specimens in contact, I cannot say that I ever saw any which were exactly intermediate. 


\section{NULLII ORA, Lamarck.}

The character is the same as that of the family, of which there is no other genus.

1. N. POLYMORPHA, " is in solid masses, irregularly ramose, and tuberculuted."

Plate XXIV. Fig. 1, 2, 3. Plate XXV. Fig. 2, 3.

Corallium album pumilnm nostras, Raii Hist. i. 62 ; Syn. i. 32. Corallium pumilım album, Ellis, Corall. 76, no. 1, pl. 27, fig. $c$. Millepora polymorpha, Lin. Syst. 1285. Ellis and Soland. Zooph. 130. Berk. Syn. i. 211. Turt. Gmel. iv. 638. Turt. Brit. Faun. 205. Stew. Elem. ii. 428. Mull. Zool. Dan. prod. 253. Fabric. Faun. Groen]. 433. Bosc, Vers, ii. 341, pl. 25, fig. 3. Jameson in Wern. Mem. i. 560. Flem. Brit. Anim. 528. Hogg's Stock. 37. Bellamy's, S. Devon, 269. Hassal in Anim. Nat. Hist. Nov. $1840,174$.

Millepora calcarea, Pall. Elench. 265.

M. polymorpha, var. rubescens, Esper, Millep. tab. 16, fig. 1-4; and var. ramosa, tab. 14, fig. $1-3$.

M. informis, Lam. Anim. s. Vert. ii. 203. 2de edit. ii. 311. Risso, L'Europ. Merid. v. 348.

Nullipora informis, Sclwveig. Handb. 412. Templeton in Mag. Nat. ix. 470. Blainv. Actinol. 605.

$H a b$. "Common on submarine rocks, in shallow water," Fleming. 
This coral, which is of a stcny hardness and solidity, occurs in irregularly branched nodulous masses, adhering at first by a small circumseribed basis, but becoming readily detached, and hence generally found free or loose. "It is of very different colours, as red, yellow, greenish, ash-coloured, but seldom white." "It is often shaped liked the kernel of a walnut, often in larger compressed masses, sometimes like a bunch of very small grapes, most frequently in tuberculated branches. It is found from one inch to three inches long. When it is taken out of the sea, it is covered with a slime. The pores on the surface are very small, so that to see them it is necessary to wipe the slime very clean off, and to use a large magnifier." Ellis.

I have received from my Irish friends two varieties which deserve to be distinguished. The onc forms circular deeply lobed crustaceous masses adhering only in the centre. (Pl. XIIT, Fig. 3.) The other is also crustaccous, but the surface, which is uneven or nodulous, is punctured like the top of a thimble. (Plate XXV. Fig. 2.)

The mass is occasionally drilled with small circular holes, which are the work of some saxicarous worms.

Ray tells us that this coral is " dredged out of Falmouth Haven to manure their lands in Cornwall." Mr Thompson informs me that it is dredged up in Bantry bay for the same purpose. According to Dr Fleming, it is found in such abundance in Orkney " as to warrant the conclusion, that it might be advantageously employed for the purposes of agriculture and building, especially as limestone in Orkney is scarce, and generally of bad quality, some of it containing 20 and even 30 per cent. of impurities." Edin. Phil. Journ. viii. p. 301.

Of the cathedral of Icolumbkil the eement, says Dr Walker, "like that of other ancient structures, is so strong, that it is easier to break the stones than to force them asunder. It is of lime that has been calcined from sea-shells, and formed in- 
to a very gross mortar, with coarse gravel, in a large proportion, and a great quantity of the fragments of white coral, which abounds upon the shores of the island." Essays, p. 133.

2. N. CALCAREA, "is extremely white, solid, and dichotomously branched; the little branches of ten unite together and become smaller at the ends."

Plate XXIV. Fig. 4, 5.

Millepora calcarea, Ellis and Soland. Zooph. 129, pl. 23, fig. 13. Lam. Anim. s. Vert. ii. 204 : 2de edit. ii. 312. Bosc, Vers, ii. 344 .

M. polymorpha, var. tophiformis, Esper, Millep. tab. 15 .

$H a b$. On the coasts of the south of England and west of Scotland. Devonshire, $D r$ Coldstream.

Coral from one to two and a-half inches high, white, solid and calcareous, the branches sometimes few and distant, at other times numerous, short and inosculating : the surface is smooth or in some places marked with depressed mammillary tubercles. It is certainly nothing but a different state of the preceding : and Pallas has rightly commingled their peculiarities in his description of Millepora calcarea.

3. N. FASCICULATA, tufted and much branched, the branches erect, dilated upwards with flattened and often dimpled apices.

\section{Plate XXIV. Fig. 6.}

Millepora fasciculata, Lam. Anim s. Vert. ii. 203 : 2de edit. ii. 311. Risso L'Europ. Merid. v. 348.

Nullipora fasciculata, Blainv. Actinol. 605.

Hab.-The coast of Ireland, whence specimens were sent to me from Mr Ball, through the medium of William Thompson. They were gathered in Roundstone Bay.

This coralline has a great resemblance to the lichen named 
Ramalina fastigiata. It is less stony than N.polymorpha. The surface is smooth and imperforate, of a pale pea-green colour ; the interior yellowish-white, solid and as unporons as the surface. It grows in irregular masses from one to two inches in diameter.

4. N. AGARICIForinis, coral composed of thin foliaceous lamina twisted into sinuous folds.

\section{Woodcut, No. 23.}

Hosco petroso, Imperat. Hist. nat. 600, cum fig.

Millepora agariciformis, Pall. Elench. :263. Lam. Anim. s. Vert. ii. 204 : 2 de edit. ii. 312.

Millepora coriacea, Limn. Syst. 1285. Esper, Millep. tab. 12. Bosc, Vers, ii. 343.

M. decussata, Ellis and Soland. Zooph. 131, tab. 23. fig. 9. Esfer Millep. tab. 25, fig. 1-4. Losc, Vers, ii. 344.

II. tortuosa, Esper, Nillep. tab. 22.

Nullipora agariciformis, Blainv. Actinol. 605 .

Hab. " Dr Farran of Feltrim near Dublin informs me that it is found on a small bank in water about fifteen feet deep, and appears like paving stones at the bottom: the only locality he knows is Roundstone bay, Connamara, where he observed it seven or eight years ago." TWm. Thompson.

This interesting coralline grows in globular masses as large as a man's fist, or larger, made up of thin foliaceous lamina folded into sinuons cavities and freely inosculating. The entire mass is rery light and fragile, rather elegant, and of a whitish colour. The lamina are thin, even on the margins, smooth on both sides, solid and entirely destitute of pores.

The description which Pallas has given of this coralline is so grood that I give it here entire: "Lumine semicirculares, plane, satisque tenues, nuargine subarguto, plerumque subparallelar, interdum decussantes varieque coalitxe. Substantia dura, albis- 
sima, solida. Superficies lævis, poris conspicuis plerumque nullis."

When a piece is steeped in a diluted acid, and the calcareous matter removed, a soft membrane remains retaining the size and figure of the original. Examined with a moderate magnifier, this appears to be marked with close parallel striæ crossed concentrically with others at little wider intervals, exhibiting just such an appearance as Ellis has represented in prepared portions of Corallina officinalis and Millepora lichenoides. If, however, a higher power of the microscope is used it will be seen that these striæ are all composed of nearly equal oblong cells arranged in parallel lines, and laid in or upon the mucaginous matrix on which the figure really depends. There are no cells on the marginal line which is entirely mucaginous; and there are numerous minute granules immersed in that portion of the matrix which contains the cells. (See Plate XXII. Fig. 8.) It is very evident from this anatomy that this Nullipore is an organic production; and indeed there can be little doubt of its being a state of the Millepora lichenoides, which we have already described as merely the basis of Corallina officinalis.

" Nilil imutile, nilil vanum, nihil supervacaneum iı Natura!"- Bacon 


\title{
SY NOPSIS
}

\section{SPONGIARUM ET LITHOPHYTORUM}

\author{
QUER IN AQUIS BRI'TANNICIS
}

NASCUNTUR,

CUM RECENSIONIBUS ET CHARACTERIBUS EMENDATIS.

\section{Classis-A MORPHOZOA.}

Character.-Zoophyta fixa, multifornia, varias figuras induentia: corpus per totum plerumque consimilia, stupea aut subearnca aut quasi e pilis coactis composita: sensu et motu voluntario expertia, sub aquâ vitam degentia el aquam tantum respirantia: gemmis c corpore turgentibus, aut scminibus mueosis nascuntur.

\section{Genus-TETHEA.}

Character.-Spongia tuberosa, subglobosa, cute crassî obdncta, intus inedulla spiculisque siliceis referta; spiculis fasciculatis, e nucleo subcentrali radiantibus : osculis raro perspicuis._-Tethea profunda maris et littora aque frequentat. 
1. T. C'rayun, globosa, superficie villosa aut setosa; spiculis e cute protrusis trifurcatis.

2. T. Lycuriun, globosa, supemâ superficie vermcosa; spiculis aculeatis et in cute cum corpusculis stellatis commixtis.

\section{Genus-GEODIA.}

Character.-Spongia tuberiformis, carnosa, canaliculis irregulariter permeata, aciculis siliceis fasciculatis et ad peripheriam radiantibus referta; externa superficie globulis siliceis in crustam agglutinatis vestita.___Pelagium eșt hoe genus.

1. G. ZETLANDICA, globulis vestita rotundis, minutissime reticulatis, lævibus; spiculis e cute non eminentibus.

\section{Genus-PACHYMATISMA, * Bowerbank.}

Character.--Spongia carnosa crustacea nec cellulosa nec vi resiliendi prædita, cute crassâ lævi osculis sparsis perforatis obsita; spiculis siliceis et aciculiformibus et stellatis sparsis, et gemmulis siliceis ubique commixtis, referta. Obs. A Tethcâ et Geodiâ differt hoc genus littorale externâ facie, et dispositione aciculorum, et cutis structurâ ; ab Halichondrix speciebus carnosis in spiculis ejus multiformibus.

1. P.Johnstonia. Unica species quam sub nomine Halichondrix Johnstonix supra descripsit J. S. Bowerbank.

\section{Genus-HALICHONDRIA.}

Character.-Spongia conformis, facie et structurâ varia et mutabilis, contexta vel e fibris reticulatis atque spinulis commixtis, vel c spiculis siliceis jure quasi gelato vestitis, ductibus aquiferis ubique peimeata qure in osculis aut fo-

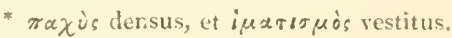


raminibus ad superficiem evadunt: spicula sunt semper silicea et in plurimis aciculiformia.—_Littora maris Halichondria maxime petit.

* H. fibris subcorneis spinuliferisque contextre. A. Fruticos.e, seu Caulescentes.

1. H. PALMATA, erecta compressa porosissima ramosopalmata ; ramulis digitiformibus apice furcatis subacutis; osculis inordinatis subprominulis.

2. H. oculata, ramosissima mollis tenera flarescens; ramis teretibus obtusis; osculis sparsis; spiculis breviusculis acutis.

3. H. CERvicoris, ramosa tenax in latum expansa fere dichotona, ramis stıpeis hispidulis ad axillas compressis, extremitatibus digitatis.

4. H. HISPIDA, sparse ramosi, ramis cylindraceis erectis longis gracilibus rigidis superficie hispidulis; spiculis obtusiusculis. $[\dagger]^{*}$

5. II. RAMOSA, ramosa-palmata rigida, ramis fibratis apicibus nudis. $[\dagger]$

\section{B. Polymorpile.}

6. H. MoNtagitu, mollis ramosissima basi incrustata ; ramulis cylindraceis tortuose divaricatis subcoalescentibus interdum furato-tubulosis; spiculis linearibus acutis.

7. H. Columb.t, amorpha bibulit mollis ex ramis difformibus et rursum confluentibus facta ; osculis sparsis ; spiculis curvatis acutis. $[\dagger]$

- Speeies obelo $f$ signate mihi nou risa sunt. 
8. H. Plumosa, amorpha molliuscula tenax porosa stupea $e$ fibris fimbriatis contexta. $[\dagger]$

9. H. FRuticosa, amorpha sessilis asperata ; fibris laxissimis inordinate connexis tenacibus crassinsculis, spiculis brevibus et obtusis refertis.___ Siccata Cladoniæ rangiferinæ (Li chenis) varietates hæe spongia quodammodo refert.

\section{* * H. cellulosa-seu pani spongioso similes.}

\section{A. Figurate.}

10. H. infundibuliformis, formam gerens infundibuli molliuscula porosissima intus cellulosa; spiculis acutis.

11. H. ventilabrum, infundibuli vel flabelli formam gerens stupea venis lignosis reticulatis porosissima pilis hirsutis plus minusve obtecta; spiculis longis linearibus varie curvatis.

\section{B. Informes.}

+ Halichondrice verce, spiculis utrinque acutis.

12. H. simulans, subramosa difformis suberosa, ramis brevibus nodosis, nodulis plerumque osculo magno perforatis ; spiculis brevibus curvatis acutis.__ Variatur infinite,_-aliquando etiam simplex et papillam fæmine lactantis referens.

13. H. cinereA, erustacea tenera (desiccata fit pulverulenta), superficie lavi et plana osculis inconspicuis ; spiculis curvatis breviusenlis acutis.

14. H. ALBESCENS, fibro-carnosa pyriformis lævis, osculo unico subterminali; spiculis brevibus subæqualibus lentè curratis utrinque acutis.

15. H. PANICEA, crustacea flavens latè vagans figurấ variâ diversitati locorum accommodatâ, superficie nunc læevi nunc papillis magnis perforatis asperatâ, cute subtilissime porosâ vestita, intus medullam panis referens; osculis rotundis margina- 
tis ; spiculis lente curvatis acutis formâ semper constantibus.

Proteus ipse non magis variatur, hine subjumguntur definitiones auetorum :

"Spongia amorpha albida mollis tenerrima, subtilissime porosa." Pallas.

"Spongia plana compressa erecta mollis, poris prominulis superne seriatim dispositis." Solander.-Hæe definitio varietatem $\delta$ depinget.

"Spongia multifornis porosa, spinulis intertexta, tenerrima mollis." Solander.

"Aleyonimm (medullare) incrustans, irregulare, polynorphum album, subtilissime reticulatum." Lamarck.

16. H. AREOLATA, inerustans iregularis nee bibula nec vi resiliendi prædita alveolata muco pisculento seatens; osculis porisve nullis; spiculis raris breviusenlis curvatis utrinque acutis.___ In dubium revocari potest utrum bac spongia varietas sit Dysidece fragilis?

17. H. ACULEATA, crustacea crassal informis inperfecte cel. lulosa sieca friabilis, spiculis longissinis hispida.

\section{$+\dagger$ H. verce, spiculis subulatis capite obtusiusculo.}

18. H. rucorus, amorpha in nodulis spongiosis plerumpue fucos restions porosa ; osculis paueis aut nullis ; spiculis breviusculis curvatis hêc quam alterê parte acutioribus.

19. Hi. Ixcrustaxs, sessilis crassa informis fulva of collulosa, superficie rudè porosal; osculis paucis sulstellatis depresuis; spiculis brevilus rectis extremitate alterâ obtusis alterâ icuminatis.

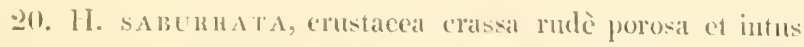
subsinilis ; osculis papilliformibus sparsis immarginatis ; spiculis is /I. imerustuntise conformibus, ot hine spongian hane ejus varielatem esse slopicor. 
21. H. æGAGROPILA, amorpha orbiculatim plerumque congesta, intus fibrosa et rudè cellulosa, extra cute papyraceâ et numerose mamillatâ restita, mamillis perforatis; spiculis acuminatis capite obtusiusculo.

22. H. SERIATA, crustacea tenax fulva superficie planâ lævi minutissime porosa ; osculis numerosis æqualibus seriatim dispositis; spiculis brevibus crassis lente curvatis subulatis capite obtusiusculo.

23. H. CELATA, informis flava duriuseula nec bibula imperfecte cellulosa foraminibus rotundis ubique pertusa, foraminum osculo plerumque papillâ clauso ; spiculis capitılo globoso.Varietates sunt : (A)_Massa informis et crassa conchyliis sabuloque referta spongiæ veræ structuram minime exhibens: -(B) Conchicola, foramina conchæ ostreorum spongiositate flavâ implens :-(C) Crustacea spongiosa maculis villosis conchylia vestiens.

24. H. SANGUINEA, crustacea irregulariter diffusa sanguinea superficie lævi; osculis parr is sparsisque planis ; spiculis longis subulatis lente curvatis.

$$
+++H \text {. dubix-a me non visx. }
$$

25. H. AUREA, crassa informis fusco-flava superficie inæquali, muco oppleta.

26. H. coxus, informis lobulata fusco-flara muco scatens, spiculis hirsuta.

27. H. RIGIDA, sessilis rigida flavescens porosa irregulariter lobata, muco plena.

28. H. PERLEVis, crustacea in?egularis flava subtilissime cellulosa extra papillis parvis obtusisque obtecta.-An varietas $H$. seriate? 
*** Spongice solide et durœ homogenece.

29. H. COALITA, ramosissima diffuse vagans, ramis varie implexis et confluentibus tereti-compressis, osculis parvis et sparsis munitis; spiculis utrinque acutis.

30. H. virgultosa, stipite duro simplici vel ramoso, ramis subteretibus rirgatis erectis acutiısculis, superficie pannosâ; spiculis subulatis capite obtusiusculo.

31. H. hirsuta, crustacea irregularis granosa et superficie rillosa, nec poris distinctis nec osculis munita; spiculis subulatis.

32. H. sUBEREA, tuberiformis cochleas uniralvas obvolvens compacta superficie læviuscula, osculorum expers; spiculis subulatis capitulo globoso munitis.

33. H. mamLlaris, difformis griseo-flarescens crustacea, intus fibroso-spongiosa, "tubulis conico-flexuosis in superficie eminentibus inæq̨ualibus."

34. H. Ficus, turbinata compacta solida superficie læri et glabrâ; osculis inconspicuis sparsis ; spiculis subulatis inæqualibus.

35. H. CARYOSA, ficiformis carnosa solida superficie leri et glabrê, colore cinerea; spiculis capite globoso.

36. II. SEvosA, sessilis alba in cristam complanatan furmata, compacta sericea; spiculis fusiformibus longiusculis utrinque acutis lente curvatis.

\section{Genus-SPONGILLA.}

Character. Spongia viridis et foctida, aquam fluviatilem incolens, multiformis, sine ordirie diffusa, intus lacunis cavernisque imperfecti permeati : cellula inæquales, quarum 
parietes exspiculis siliceis jure quasi gelato in fibras agglutinatis contexuntur, mucum turbidum includunt, atque interdum ovis innumeris seu sphærulis semina eohibentibus replentur.

1. Sp. Fluviatilis, mollinscula fragilis, texturâ rariusculâ, spiculis lente curvatis utrinque acuminatis._- Varietates principuæ in verbis cel. Lamarchii bene descriptæ sunt :

(1.) "Sp. pulcinatu, subincrustans, sessilis, crassa, convexa, sublobata; osculis majusculis, sparsis.

(2.) “Sp. friabilis, sessilis convexa, obsoletè lobulata, intıs fibrosa, fibris longitudinalibus, ramuloso-cancellatis.

(3.) "Sp.ramosa, sessilis, ramis elongatis subteretibus inæqualibus, lobulatis."

2. Sp. Lacustris, duriuscula fragilis, texturâ fibrosâ ; spiculis brevioribus utrinque acutis. $[\dagger]$

\section{Genus-SPONGIA.}

Character. Stirps radicata multiformis e fibris reticulatis contexta flexilis bibula porosissima, osculis majusculis nunquam in papillis elevatis superficie sparsis.—-Species plerumque pelagiæ.

1. S. PUlChella, sessilis multiformis varie lobata mollis et tactum permulcens porosissima, fibris concinnè reticulatis lævibus nudis; osculis sparsis obsoletis.

2. S. limbata, sessilis informis simplex aut lobulata molliuscula porosissima, fibris reticulatis et spiculis minimis refertis mudis; osculis sparsis._-Species littoralis et parra.

3. S. Levigata, mollis bibula, superficie levi, minutissime porosa ; fibris tenuissimis pulchrè reticulatis. [†] Incerti generis. 


\section{Genus-DYsideA (Duseideia.)}

Character. Spongia multiformis sessilis crassé cellulosa mucagine sabulo arenatâ scatcns, siccata friabilis, fibris imperfectis seposita : spiculis sparsis paucis formâ et magnitudine incertis.

1. D. FRAGıLIs, informis sessilis crassa arenâ asperata, siecata friabilis, spieulis paucis nec certæ figuræ.

2. D? PAPILlosa, arenacea lutosa crustacea mamillis cylindraceis perforatis, apicibus rotundis et ocellatis, ornata. Corhleas incrustans.

\section{Genus-HALISARCA.}

Character. Spongia gelatinosa diffuse repens cute temui et leevi vestita spiculis et cellulis fibratis carens.-Genus littorosum, rupes et fucorum radices ornans.

1. H. Dujardini. Generis unical species.

\section{Genus-GRAN'TIA.}

Character. Spongixe plerumque albicantes minutissime porosæ nec vi resiliendi predite, e spiculis calcarcis multiformibus in membrana gelatinosa contexte; osculis rotundis planis.-Parvum serl nitidum genus fucos confervasque littorales amans, nec rupes effugiens.

\section{* Carce.}

1. Gro compressa, simplex compressa foliacea subtilissime porosa leeris: osculis paucis rel in apice vel in margine perforatis; spiculis clavatis et triradiatis.

2. Gill Lacuxos.1, simplex thabellatim complanata brevi pe- 
diolo fulta, lateribus lacunatis, osculo terminali ; spiculis trifurcatis.

3. Gr. cilinta, simplex tubulosa conico-flexuosa vel ovata muricata, apice spinulis erectis vitreis ciliato.-Varietas aliquando invenitur ore ciliis brevibus aut fere nullis circumdato.

4. Gr. Pulverulenta, simplex minima ovata superficie villosa ; spiculis aut simplicibus ant trifurcatis. [†]

5. Gr. fistulosa, simplex lineari-elongata compressa subvillosa superficie lævi, osculo unico terminali inermi; spiculis triradiatis inæqualibus, plurimis majusculis.

6. Gr. воtryoides, ramosissima alba varie implexa, ramis incertis tubulosis subvillosis apicibus apertis; spiculis trifurcatis.__ Obs. Facies diversas hæc spongia facile assumit.

\section{* * Crustacce.}

7. GR. NiveA, crustacea alba siccata friabilis nune plana nunc in cristas plicatiles insurgens, osculis sparsis ; spiculis plurimum trifurcatis, quibus pauca quatuor radiis ornata interdum admiscentur.

8. GR. COR 1 ACEA, crustacea mollis fulva et subcarnosa crassè porosa; spiculis parvis trifurcatis. 


\section{Classis-LITHOPHYTA.}

Character. Algæ in mari nascentes, lapideæ, aut plantæ habitu gaudentes aut in crustas tenues aut in massas solidas et informes sese evolventes.

\section{Familia-CORALLINE E.}

Character. Algæ plantiformes ramosissimæ articulatæ, cx axe ccntrali vegetabili crustâque calcareâ passim interruptâ compositæ, tubercula scminalia ad apices aut in axillis ramusculorum tempestivè producentes.

\section{Genus-CORALLINA.}

Charactor. Corallina e basi explanatâ assurgens trichotoma, articulata, articulis approximatis subcompressis ; axis algensis solidus; cortex calcarea crassa poris expers.

1. C. OFFICINALIS, " trichotoma, articulis stirpium subeompressis subcuneiformibus, ramulonm cylindricis; terminalibus nonmullis capitatis." Solander._-In retate juvenili hec corallina maculas ealeareas atque crustas licheniformes ubique super rupes, saxa, fucos ol corallinas adultas format. IIa crusta: cum parre sunt et membranacex, poris nomullis pertusa, MELOBLS1. F esse species a cel. Lamouroux dicuntur ; et cum majores et erassiores crescunt tunc pro speciebus MILLEPOR ab aliis habentme.

2. ('. ELox(iATA, " trichotoma, articulis stirpim subtereticuncifurmibus ; ramormm eylindricis : summis obtusiusculis ; nonnullis capitatis." Solander.__Prore gracilior cum pinmulis ranuseulorum setaceis.

3. C. SQUAMATA, " trichotoma, articulis stirpiun rotundato- 
compressis cuneiformibus; ramulorum compressis planis ; ultimis complanatis ancipitibus acutis." Solander.

\section{Genus-JANIA.}

Character. Corallina e disco parvo assurgens, gracilis, dicliotoma, articulata, articulis approximatis propè cylindricis; axis solidus; cortex calcarea tenuior lævis.

1. J. RuBENs, " dichotoma filiformis, articulis stirpium teretibus; dichotomiæe claviformibus ; inferioribus nonnullis bicornibus."___ Varietates maximè signatæ sunt :

(1.) Cristata, "dichotoma capillaris, articulis teretibus, ramulis fasciculatis cristatis, divisuris penultimis et extremis ovariferis."

(2.) Spermophoros, "dichotoma capillaris, articulis subteretibus, divisuris penultimis et ultimis ovariferis, corniculis terminalibus setaceis." Solunder.

2. J. CORNiculata, " inferne pinnata, extremitate dichotoma." Pallas._-"Dichotoma, articulis stirpium bicornibus; ramulorum teretibus." Solcunder.-Varietas a cel. Lamouroux prinum descripta pimulis setaceis longis et crispatis insignis, Corallinis propriis adeo simillima est ut generis illius species non inaptè dicatur.

\section{Genus-HALIMEDA.}

Character. Corallina e basi ramosa, in flabellum diffusa, articulata; articuli reniformes; axis e fibris fasciculatis compositus, crustâ calcareâ tenui indutus.

1. H. opUNT1A, "trichotoma articulata, articulis compressis undulatis reniformibus." Solander-__-Hujus speciei "mare Americanum," dicitur esse locus; hinc oritur quastio ntrum species Britannica, quæ nostra littora rarissime quidem petit, non potius Halimeda Tuna, maris Mediterranei incola nota, habeatur.

Familia-NULLIPORID E.

Character. Algre calcareæ solidiusculæe homogenex, 
ant informes aut in modo corallii ramosa aut in laminas tcnues laves vel varie convolutas crescentes.-Obs. Propagines lıæ ad classem algarum malè relatæe sunt, nam a corallinis easdem natas csse credo. Scmina illorum in locis inhospitis gemmantia, et vi vegetanti insitâ admonita, formas parentibus ignotas et inclioatas tantum evolvere coguntur.

\section{Genus-NULLIPORA.}

Character._" Stirps irregularis, e gelatina animali prorsus lapidescente." Schueigger.

1. N. polyunpli A, "irregularis, glomerata, solida; ramulis grossis, brevibus, obtusis, subnodosis." Lamarch.

2. N. CALCAREA, " laxè ramosa, polỵchotoma, solida ; ramulis gracilibus ; infernè coalescentibus, apice obtusis." Lamarch. — Millepora ramosa albissima solida dichotoma, ramulis attenuatis coalescentibus." Solunder.

3. N. FAsciculata, "glomerata, densè cymosa ; ramis erectis, fasciculatis, confertis, apicè incrassatis, obtusis." Lamarek.

4. N. A riA RICIFORMIS, "alba solidissima foliosa, laminis sessilibus semicireularibus congestis." Palles._-" Millepora cretacea lamellata, laminis varie decussantilus." solumder.

"Prima laus eat humana" sapientie, valde similia posse distinguere" 



\section{EXPLANATION OF THE PLATES.}

PLATE I. Fig. 1, Tethen Cranius, of the natural size, from a specimen presented to me! by Messrs Edward Forbes and J. Goodsir. Fig. 2, A section of the same. Fig. 3, A minute portion of the surface magnified. Fig. 4, A fusiform spiculum, and Fig. 5, Three of the tricuspidate spicula of the same. Fig. 6 , The oviform bodies magnificd, and 7, One of them viewed through the microscope after compression between two plates of glass. Fig. 8, Three of the cuticular spicula. Fig. 9, The spicula of Tethea Lyncurius. Fig. 10, A minute film of the rind compressed between plates of glass, and highly magnified, to shew the starred spicula.

PLATE II. Fig. 1, IIALICHONDRia palMita. The figure is about ope. half the size of the specimen from which it was drawn. Figs 2, 3, Small specimens of the same species of the natural size; these are in the collection of Mr Bean of Scarborough. Fig. 4, Two oscula of the natural size, $a$, as they appear before the superfieial network has been removed; $b$, an open osculum with canals opening within its rim. Fig. 5, The spicula.

PLATE'III. Fig. 1, HALichoNDHA oculata, of nearly the natural size. Fig. 2, The spiculum. Fig. 3, A minute slice of GEonra ZETLANDICA magnified to sliew the structure of the crust and of the interior. Fig. 4, A few of the cuticular globules highly magnified. The fibrous fringe about them is produced by the drying of the surrounding organic mucus.

PLATE IV. Fig. 1, Halichoxpria cenviconnis, natural size, from a specinien in the collection of the late Mr Templeton. Fig. 2, A small portion magnified. Fig. 3, The pattern of HALreronoriA CINEREA as seen through a high magnifier. Fig. 4, Three of its spicula.

PLATE V. Fig. I and 2, Varieties of Halichondria cenvicornis, of the natural size. Fig. 3, The gemmules and simple and starred spicula of PACHYNATISAt Jounstonia as seen through a high magnifier. The preparation given me by J. S. Bow erbank, Esq. 
PLATE VI. Fig. 1, 2, Halichondria Montaguir of the natural size, and its spicula magnified. Fig. 3, HALICHONDleIA INFUNDIBULIForsis, and Fig. 4, Its spicula.

PLATE VIl. HalichoNDRIA veNTILABRUu of the natural size, with its spicula magnified. The figure is from an Irish specimen in the collection of R. Ball, Esq.

PLATE VIII. Halichondria simulans. The figures shew its principal varieties, drawn from specimens sent to me by Dr Scouler of Dub. lin. Fig. 6, the spicula.

PLATE IX. Halichondria FUCORUM with its spicula.

PLATE X. Halichondria panicea. Fig. 1 , The sponge in its primary crustaceous condition. Fig. 2, in its crustaceous and normal state. Fig. 3, In an irregular lobulated and papillary state. Fig. 4, With a looser and more friable texture than is usual. Fig. 5 , in its frce massive condition. Fig, 6, A section of two oscula to shew how the canals open into them, and the effluent currents. Fig. 7, The orifice of an osculum magnificd. Fig. 8 , A thin slice of the sponge magnified to shew its structure. Fig. 9, The spicula magnified.

PLATE XI. Fig. I, HaLICHONDRIA AgAGROPILA, from a specimen in the collection of Dr Scouler of Dublin. Fig. 2, The spicula. Fig. 3, Haliciondria saburrata, and Fig. 4, Its spicula. Fig. 5, HaLichondria panicea, var. papillaris, and Fig. 6, its spicula.

PLATE XII. Fig, 1, 1, 1, Halichondria coalita of the natural size, with its spicula magnified. Fig. 2, HAL. FUCORUM, investing a portion of Plumularia falcata, whence the peculiarity of its form. Fig. 3, 3, HaL. incrustans in its crustaceous state with the spicula. Fig. 4 , A picce of a sponge supposed to be the Spongia pilosa of Montagu, but probably a state of Dysidca fragilis. Fig. 5, 6, 6, HAL. SUBERIA of the natural size with its spicula viewed with a high magnifier.

PLATE XIII. Fig. 1, 2, 3, HALICHONDRIA ACULEATA with its spicula. Fig. 4, 4, HaL. AREOLATA with the spicula. Fig. 5, 5, HaL. INCRUstans with the spicula. Fig. 6, Drsidea rragilis of the natural size from a dricd specimen, with various forms of its spicula. The latter are from sketches furnished by J. S. Bowerbank, Esq. Fig. 7, 8, HaL. CAR Nosa with its spicula.

PLATE XIV. Fig. 1, HalichoNdRIA FRUTicosa, from a specimen which had been washed ashore and lost its organic mucus. Fig. 1, $a$. A small portion of the fibre magnified. Fig. 1, b, The spicula. Fig. 2, 2, Hal. seriata. Fig. 3, 3, Hal. sanguinea with its spicula. Fig. 4, Drsidea fragilis in a dry condition.

PLATE XV. Fig. 1, Halichondria virgultosa, natural size. Fig. 2, A small slice seen through a low magnifier. Fig. 3,3, The spicula. Fig. 4, 5, Hal. Facus, from specimens in the collection of Mr Bean. Fig, 6, The spicula, from a specimen given me by $M r$ Edward Forbes. 
PIATE XVI. Fig. l, Halichondria hirsuta of the natural size. Fig. 2, HaL. majmillaris of the natural size, from a specimen in the collection of William Thompson, Esq. Fig. 3, HaL. SEvosa, natural size. Fig. 4, A portion magnified to show the spicula protruding from the organic mucus. Fig. $4, b$, The spicula highly magnified. Fig, 5, Alcroniduar gelatinosum in its primary state. The figure was engraved before the real nature of the production was detected. Fig. 6. Dysidea Papillosa of the natural size, and Fig. 7 , one of the papillæ slightly magnified, with a section of the same. Fig. 8, Halisarca Dujardinil, natural size.

PLATE XVII. Spongilla Fluviatilis. Fig. 1 , in its crustaceous, and Fig. 2, in its massive state. Fig. 3, represents it throwing up branches from a crustaccous base.

PLATE XVIII. Spongilla Fluviatilis, in its arborescent state, with its spicula and seminiferous capsules.

PLATE XIX. Fig. I, Spongia pulchilla, from a fine specimen in the collection of the late $\mathrm{Mlr}$ Templeton. Fig. 2, The same from a specimen found in Berwick bay. Fig. $3,4,5$, Spongia limbata, from spceimens from very remote localities.

PLATE XX. Fig. 1, Grantia conpnessa, of the natural size, from specimens gatlered in Berwick bay. Fig. 2, GR. LACU NosA of the natural size, and fig. 3, the same magnified, from a specinen scnt me by MrW. Bean. Fig. 4, Gr. Ciliata, from a drawing made from the living sponge by Mr Edward forbes. IF̈g. 6, GRANTIA NIVEA, a state of, from the coast of Ireland. Fig. 7, G爪. FistulosA, from a small specimen sent to me by Mr William Thompsen. Fig. 8, 8, IlALICHONDIIA ALBESCENS, of the natural size, with its spicula.

PLATE XXI. lig. I, 2, GIRATIA BOT YOIDEs, as very commonly met with. lig. 3, Gr. во'rromes in an abnormal state fronı growing underneath a flat stone. Fig. 4, A portion of this Grantia as seen through a magnitier. Fig. $5, A$ minute portion of the surfacc more highly magrificd. Fig. 6 , specimens of Giantia ciliata in an nnusual state or form; and Fig. 7 , one of the same seen through a magnifier. Fig. 8, Gu. NIVEA of the natural size. Fig. 9, Gr. coRIACEA, natural size.

PLATE XXIl. lïg. I, CoralliNa OFficiNals in its crustaceons and lichenoid state. Iig. 2, Colt. officisals, when full grown and in its normal furn. Fig. $3,4,5, \mathrm{~A}$ small portion, from different specimens, magnified ; Figg. 3 was drawn after the caleareous crust had been removed by an acid. lig. 6, A small portion of Fig. 2, deprived of its calcarcous matter and highly magnifict. Fig. 7, The scininal granules, copied from Ellis. Fig. 8, A portion of the Nullipoma AGARrciFORMIS dcprived of its calcareous earth, and highly magnified, to show its structure. 
Ols. In reference to Figure 6 , it is to be remarked, that in only some specimens could such an appcarance of vessels, as is there shown be seen, and the appearance may have been produced by folds oecasioned by the pressure between the plates of glass to which the specimen was subjected. Of Algæ, the Hon.' W. H. Harvey says, - " All consist of simple cellular tissue, or of its elements, gelatine, membrane, and endochrome, variously elaborated and perfceted. No vessels or duets have been discovercd in any."Man. Brity Algæ, Introd. p. xvii.

PLATE XXIII. Fig. 1, A tuft of Jayia rubexs, natural size. Fig. 2, A portion highly magnificd to show the cellular structure of the $a x i s$, for the caleareous crust has been removed by an acid; the tubercles containing granules; and the seminal capsules in the axils of the extreme branchlets. Fig. 3, Is another portion from-another specimen from which the crust has been likewise removed, highly magnified.

PLATE XXIV. Fig. 1, 2, 3, NulLipora polymorpha, all of the natural size. Fig. 4, 5, Nul. calcarea. Fig. 6, Nul. FascicuLATA. The specimen had been originally of greater size, but considerably broken in the carriage.

PLATE XXV. Fig. 1, Mrr.epona Lichenoides of Ellis and Solander. Fig. 2, 3, Varieties, solid and amorphous, of Nullipora poly. моRPнA. Fig. 4, The mass from which this figure was taken had the texture and consistency of NULLIPORA FASCICUrata, and it may be considered as representing a state of a coralline intermediate between that species and NuL. AGARICIFORMIS. I was unwilling to. describe it as a species, for there is in fact no end to the varieties which these abortive productions assume, originating as they do in the peculiarities of their seminal beds :

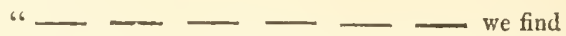

"It matters much with what first seeds are join'd;

"What site, and what position they maintain,

"What motion give, and what receive again."

Lucretius, trans, by Crecch. 


\section{N D E X.}

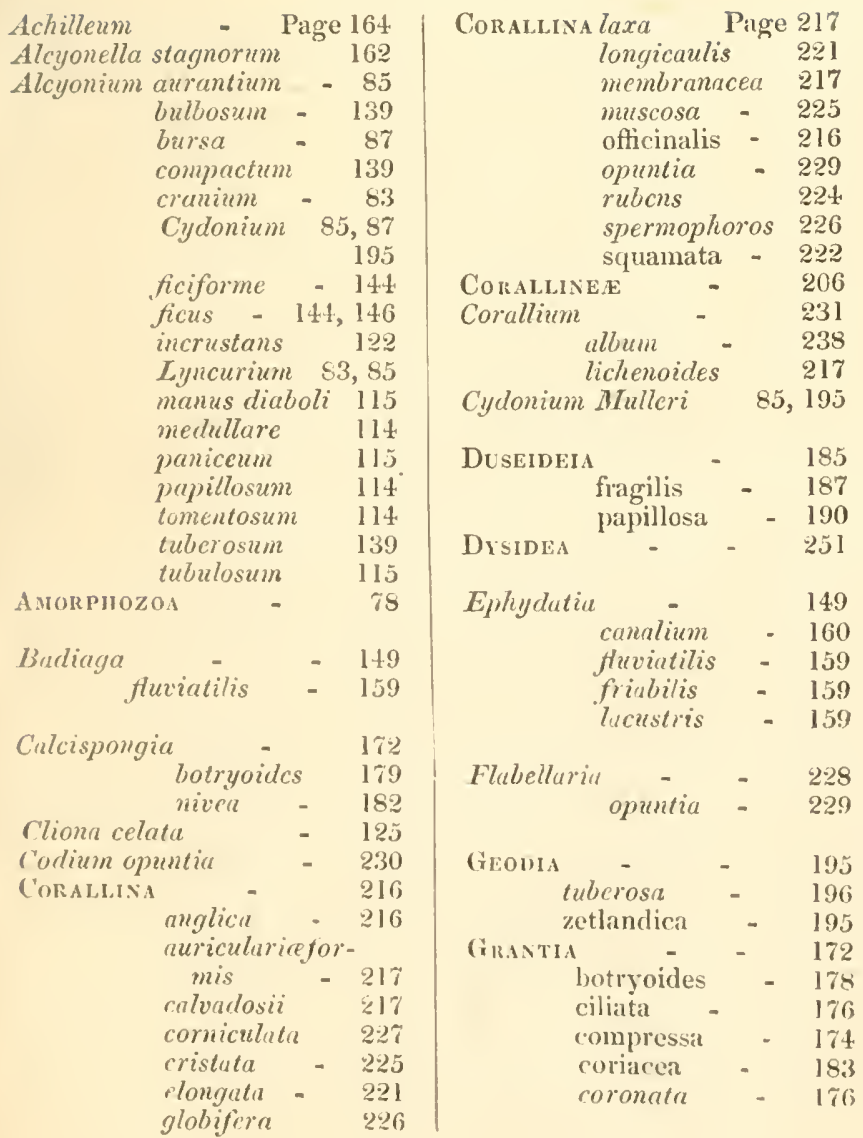


$\begin{array}{cc}\text { Grantia fistulosa } & \text { Page } \\ \text { lacunosa } & 181 \\ \text { multicavata } & 176 \\ \text { nivea } & 183 \\ \text { pulverulenta } & 181 \\ & 180\end{array}$

Haleponge panniforme 94 HalichoNdRia

aculeata 131

ægagropila 119

albescens 198 areolata

aurea 121,197
131

carnosa 146

celata 125,197

cervicornis 96

cinerea - 110

coalita - 135

columbr 101

conus - 132

ficus - 144

fluviatilis 159

fruticosa 103

fucorum 112

hirsnta 138

hispida - 98

incrustans 122

infundibuli-

formis 105

Johnstonia 198

lucustris . 162

mamillaris $1+2$

Montaguii 99

oculata $9 \pm$

palmata 92

panicea 114

panicea 122

papillaris 114

parasitica 112

perlevis 133

plumosa 103

ramosa - 99

ramosa - 94

rigida - 132

saburrata

120,197

sanguinea 133

seriata 125,197

sevosa 147,198

simulans 109

suberea 139,197

suberica 139

HaLichondria ventilabrum Page 107 virgultosa 137 ,

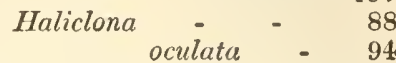

HALIMEDA - 228

opuntia - 229

\begin{tabular}{rr} 
Iratina papillaris - & 88 \\
\hline & 115
\end{tabular}

HalisarCa - 192

Dujardinii 192

Halispongia 88

agagropila 119

palmata - 93

panicea - 122

papillaris 114

parasitica 112

reptans - 109

sanguinea 134

suberica - 139

ventilabra 107

JANIA - - 224

$\begin{array}{ll}\text { corniculata } & - \\ \text { rubens } & 227 \\ \text { spermophoros } & 224 \\ & -225\end{array}$

Leucalia - - 172

Leconic - 172

Lithophyta nullipora 231

Manon oculatum - 93

Melobesia elegans - 221

furinosa - 217

membranacea 217

pustulata - 217

Millepora agariciformis $2+1$

alga - 217

calcarea 238, 240

coriacea 237, 2t1

decussuta $=241$

fasciculuta. - 240

foliacea - 217

fucorum - 217

informis - 238

lichenoides $\quad 217$

miniacea - 217

polymorpha 217,

238,240

$\begin{array}{lll} & \text { tortuosa } & \\ \text { Millepores } & 241 \\ - & 231\end{array}$ 
INDEX.

\begin{tabular}{|c|c|c|c|c|c|}
\hline Nullipora & e 231,2 & & $\begin{array}{l}\text { SPONGIA friabilis } \\
\text { fruticos } a\end{array}$ & $\begin{array}{r}\text { Page } \\
97,\end{array}$ & $\begin{array}{l}159 \\
103\end{array}$ \\
\hline agaricifor & rmis 2 & 241 & fucormm & - & 112 \\
\hline calcarea & - & 240 & hispida & - & 98 \\
\hline fasciculat & & 240 & Imperati & - & 143 \\
\hline iuformis & - & 238 & infiata & - & 180 \\
\hline lichenoide & & 217 & infundibulif & formis & 105 \\
\hline polymor & pha & 238 & lacustris 159 & 9,160 , & 162 \\
\hline Nulliporidæ & & 231 & lævigata & - & 170 \\
\hline & & & & & $\begin{array}{r}96 \\
104\end{array}$ \\
\hline $\begin{array}{l}\text { Pacnymatisma } \\
\text { Johnstonia }\end{array}$ & - & $\begin{array}{l}2+4 \\
2+4\end{array}$ & $\begin{array}{l}\text { lachemforme } \\
\text { limbata }\end{array}$ & is & $\begin{array}{l}10 \% \\
168\end{array}$ \\
\hline dina deusta & - & 237 & lobata & . & $\begin{array}{l}100 \\
168\end{array}$ \\
\hline & & & lycopodium & & 137 \\
\hline Scypha botryoides & - & 179 & mammiferis & & 143 \\
\hline cancellata & - & 101 & mamillaris & & 142 \\
\hline coronata & . & 176 & muricata & & 97 \\
\hline foliarea & - & 174 & niven & - & 182 \\
\hline lavigata & - & 170 & oculata & & 3,94 \\
\hline ovata & & 180 & palmata & - & 92 \\
\hline tubulosa & - & 99 & panicea 122 & 2,114 , & 176 \\
\hline SPONGIA - & & 164 & papillaris & & 115 \\
\hline ananas & - & 180 & parasitica & & 112 \\
\hline aurea & 1 & 131 & penicilius & & 142 \\
\hline buccillaris & - & 93 & perlevis & - & 133 \\
\hline botryoides & -1 & 178 & pilosa & - & 83 \\
\hline carulea & - & 111 & pluninosa & - & 103 \\
\hline canal um & - & 160 & jocillum & 105 , &, 107 \\
\hline calyciformis & & 105 & polychotome & $a$ & 94 \\
\hline cancellata & -1 & 101 & prolifera & - & 170 \\
\hline cervicomis & & 96 & pulchella & - & 166 \\
\hline ciliata - & - & 176 & pulverulento & a 111, & , 180 \\
\hline cinerca & - & 111 & ramosa & 94,90 & 6,99 \\
\hline clavata & 1 & 110 & rigiela & - & 132 \\
\hline coalita & 1 & 135 & sunguinea & & 134 \\
\hline columba & - & 101 & scypha & - & 107 \\
\hline compacta & - & 115 & semitubulose & & 99 \\
\hline complicata & - & 179 & seriatu & - & 125 \\
\hline compressu & - & 174 & stuposa & -96 & 6,98 \\
\hline coufervicola & & 179 & suberia & 139, &, 190 \\
\hline conus & 1 & 132 & subcrosa & 135 & 5,139 \\
\hline coriacea & - & 183 & terebrans & - & 131 \\
\hline coronata & - & 176 & tomentosa & & 114 \\
\hline crateriformis & & 105 & tubulosa & - & 99 \\
\hline crispata & - & 104 & urceolus & - & 175 \\
\hline cristata & - & 115 & urens & - & 114 \\
\hline dichotoma & - & 94 & urtica & - & 114 \\
\hline digituta & 97, 98, & 96 & ventrilubrif & formis & 107 \\
\hline echidnoa & & .96 & ventilobrum & & 107 \\
\hline fava & & 122 & verucosa & & 85 \\
\hline fuviatilis & 159,1 & 160 & virgultosa & - & 137 \\
\hline foliacea & -1 & 174 & xcranipclin & & 107 \\
\hline foliascens & & 107 & zetlandica & & 107 \\
\hline fragilis & - & 187 & Spongilla & - & 149 \\
\hline
\end{tabular}




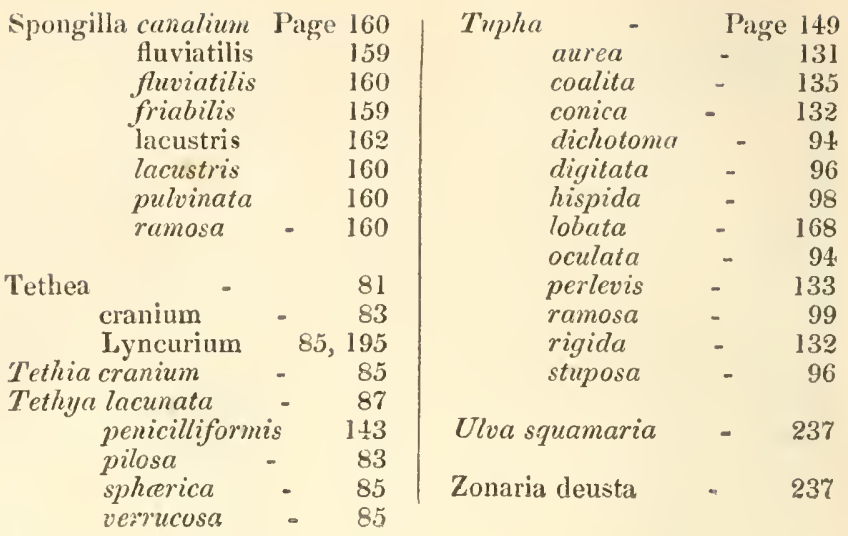




1

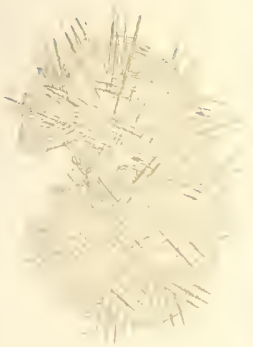

मूँ

i $\therefore \sqrt{2}$ it क्रा गे

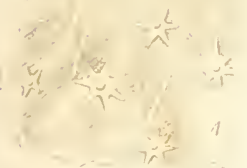
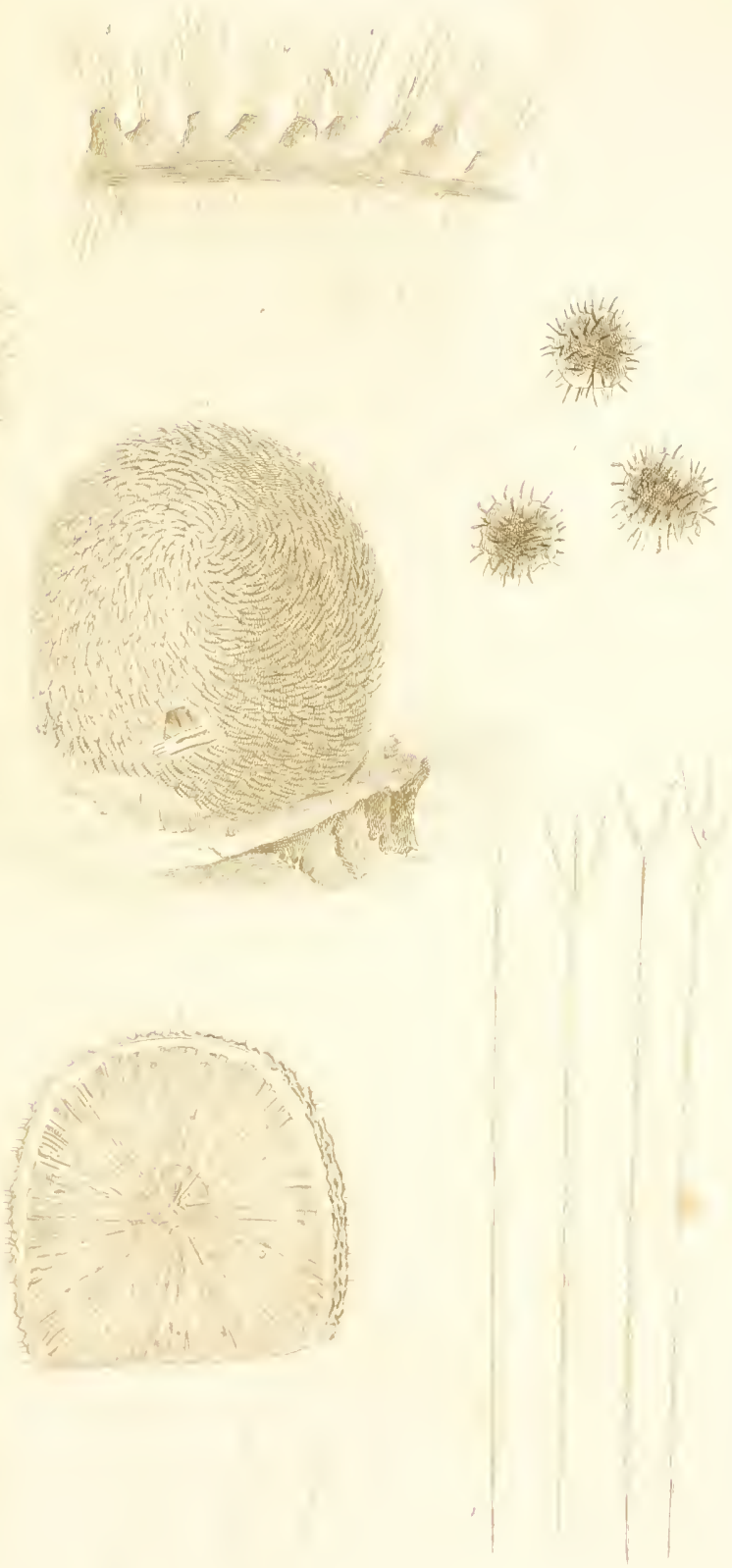



and

$\dot{x}$

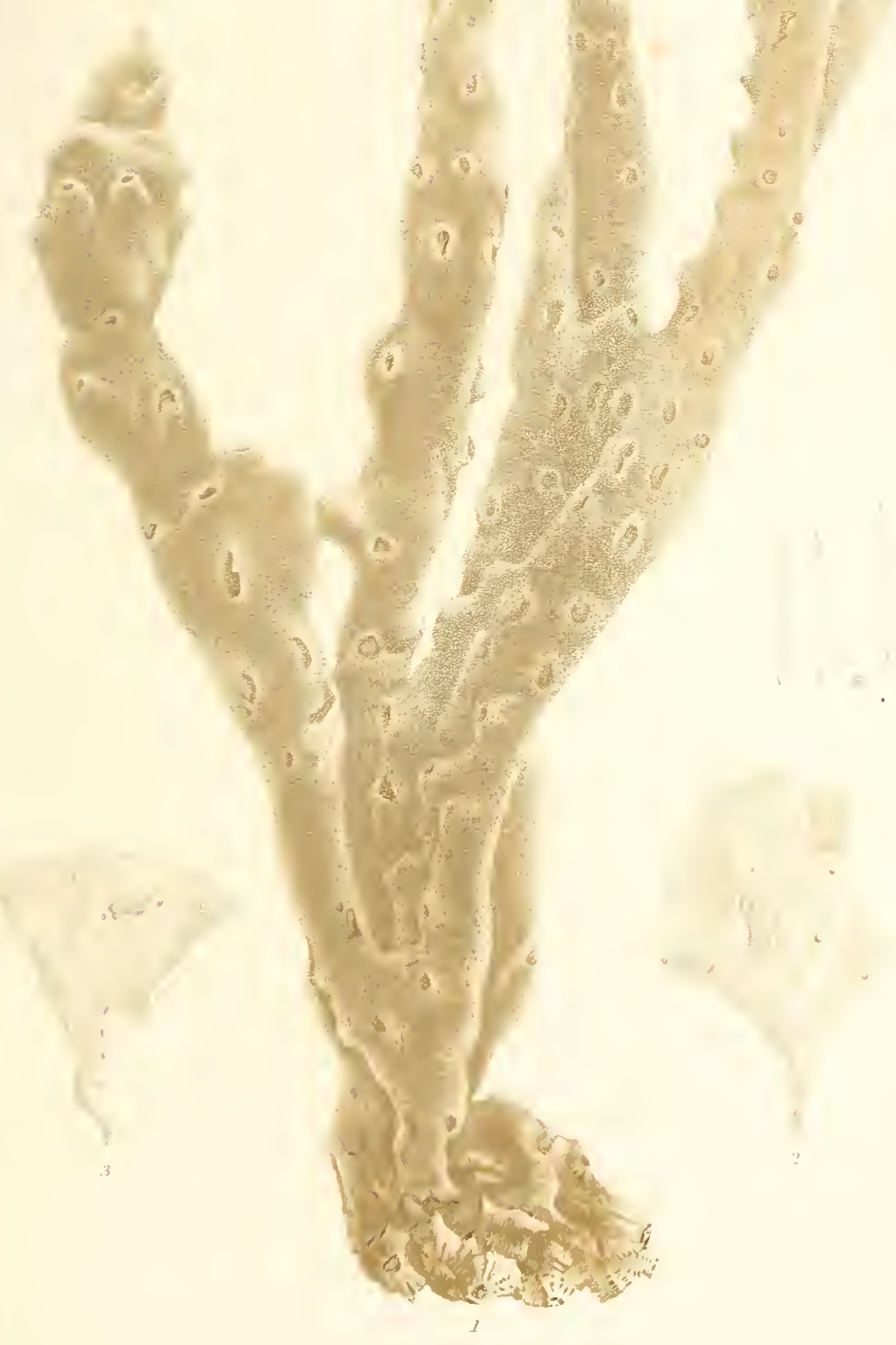






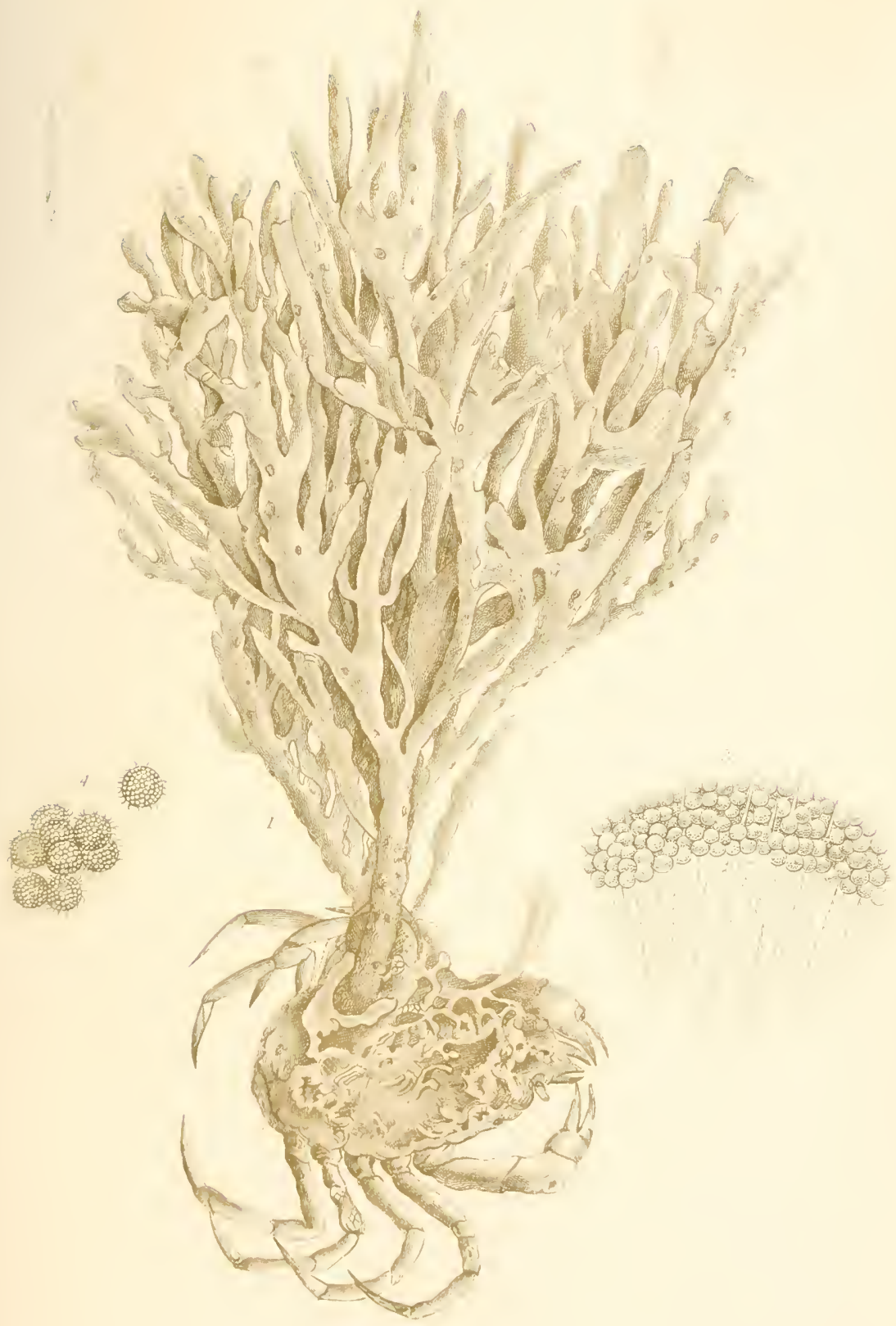







\section{in \\ पi}

Now

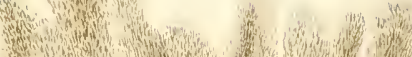

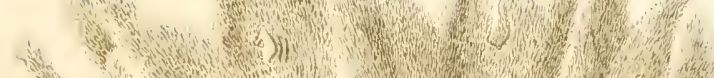

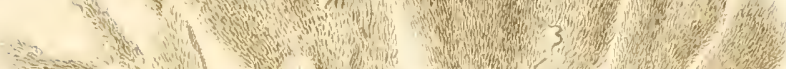
Afy

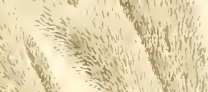
Hats
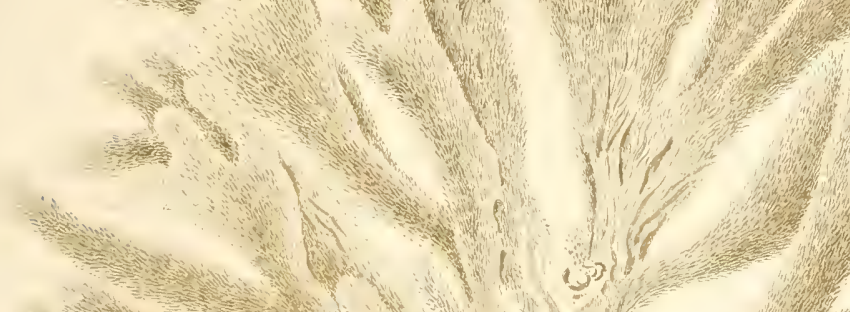

(n)
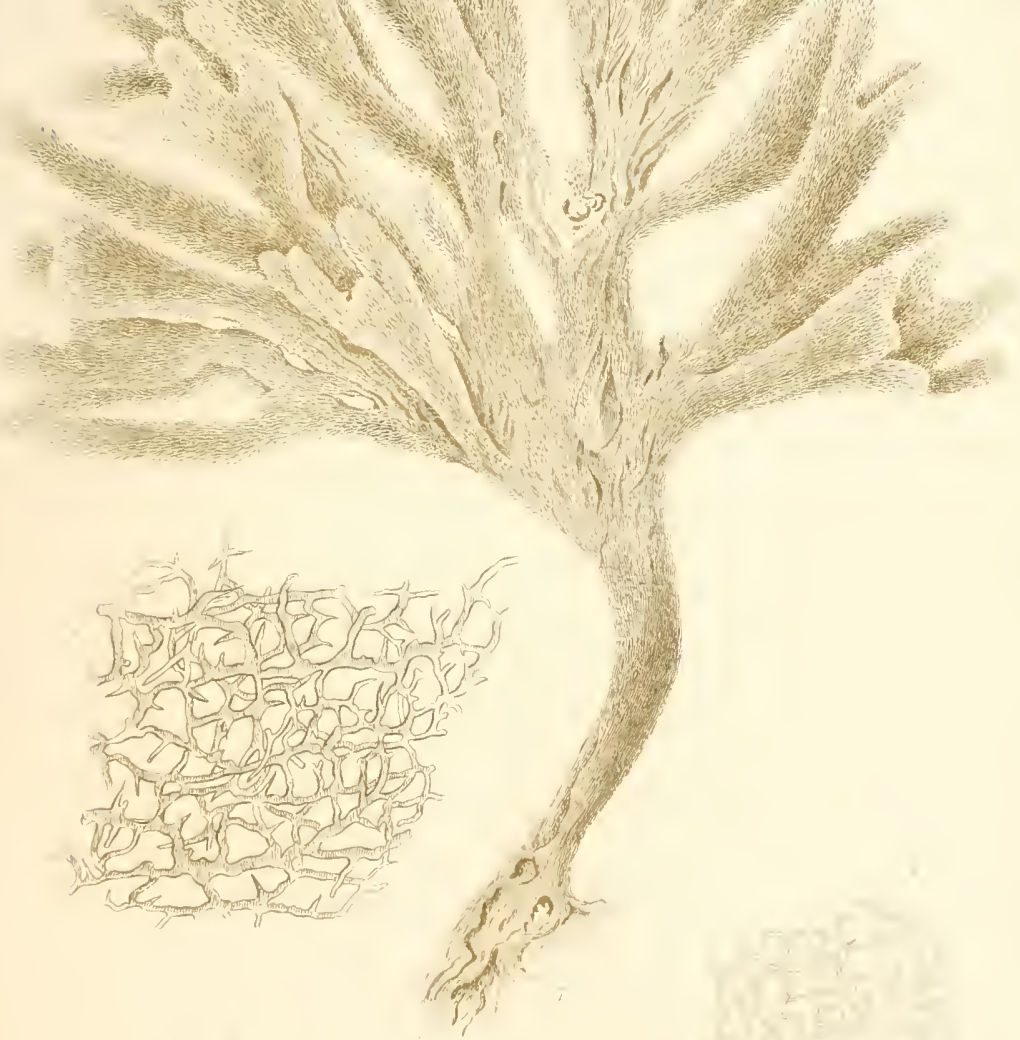





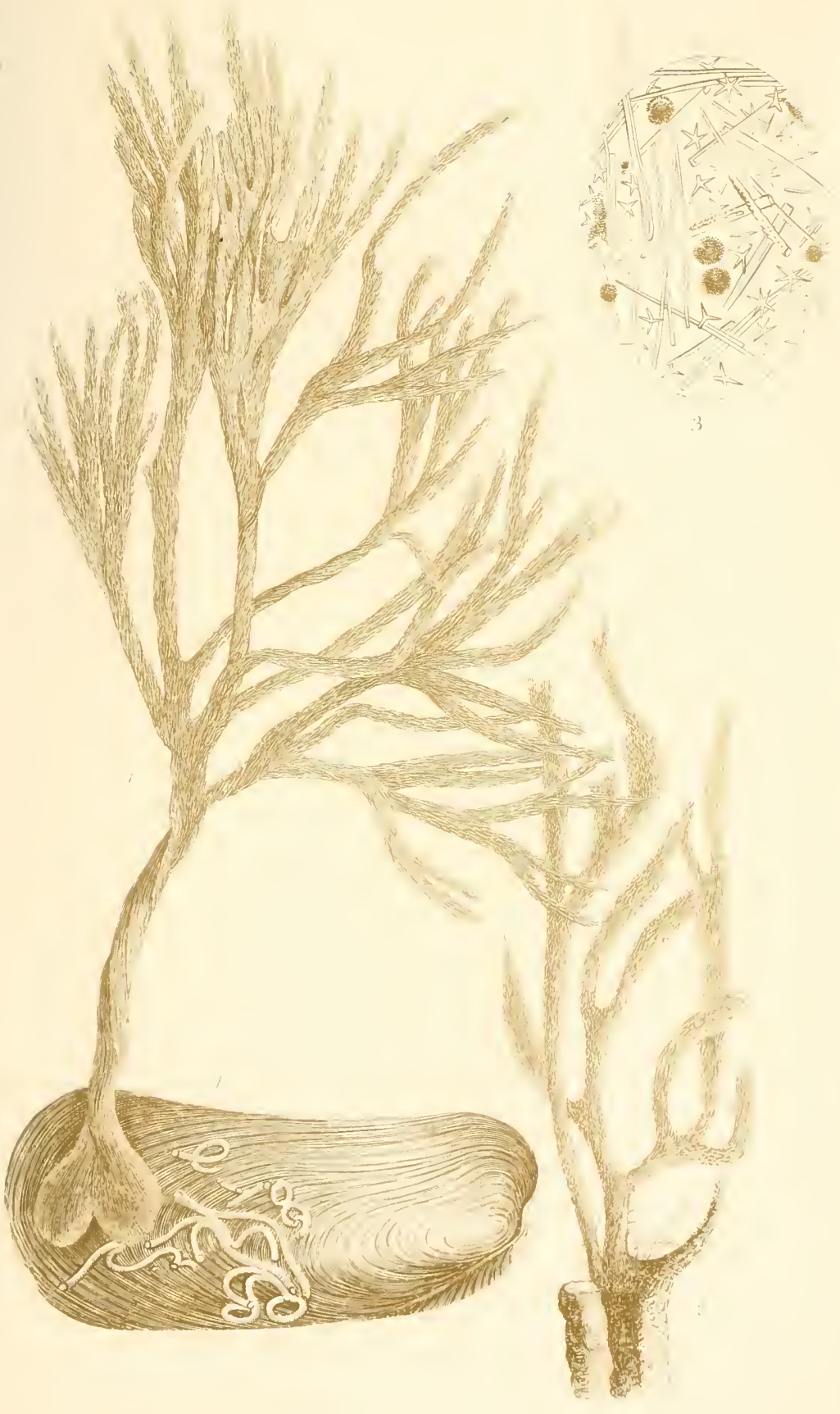





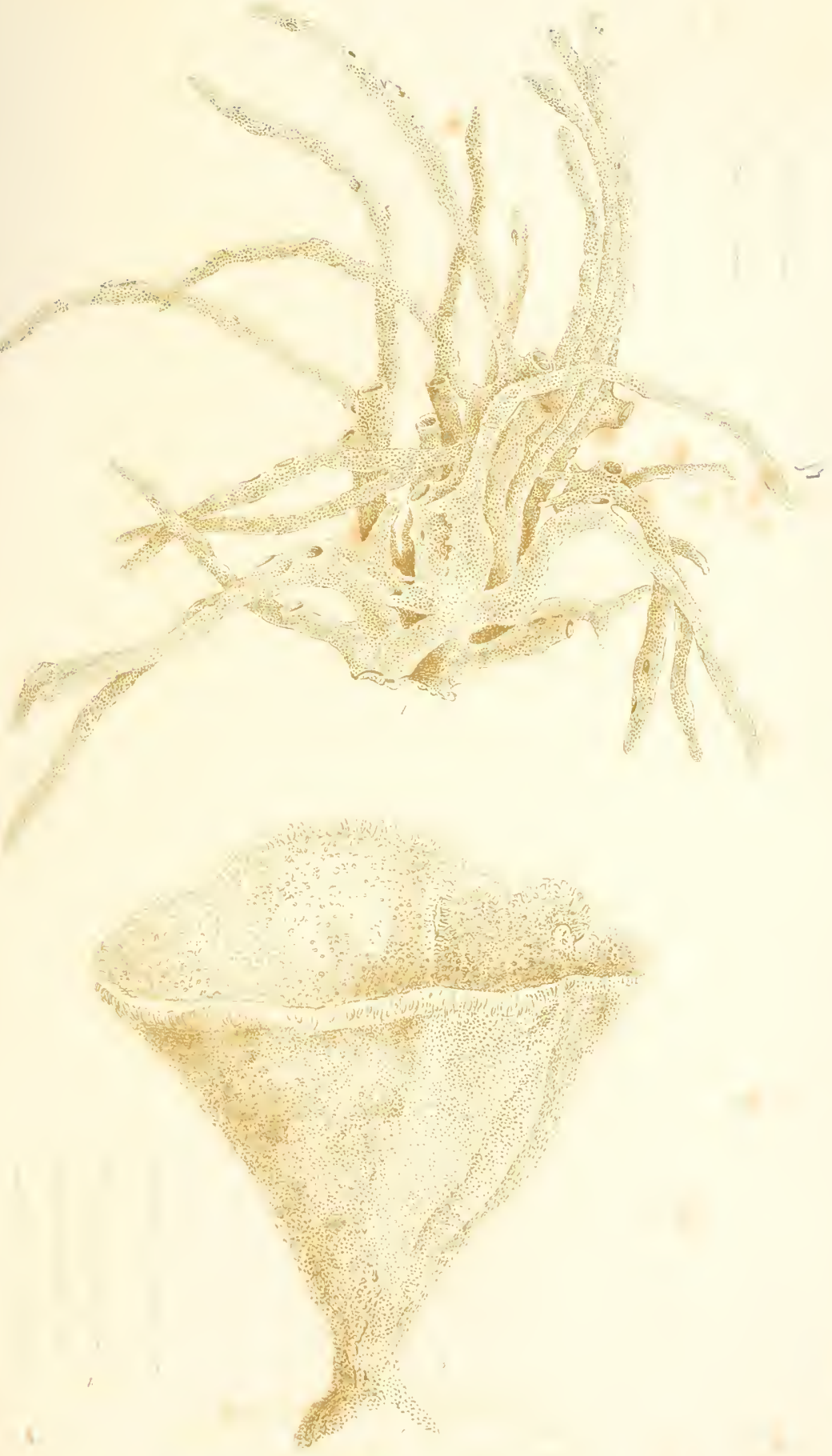




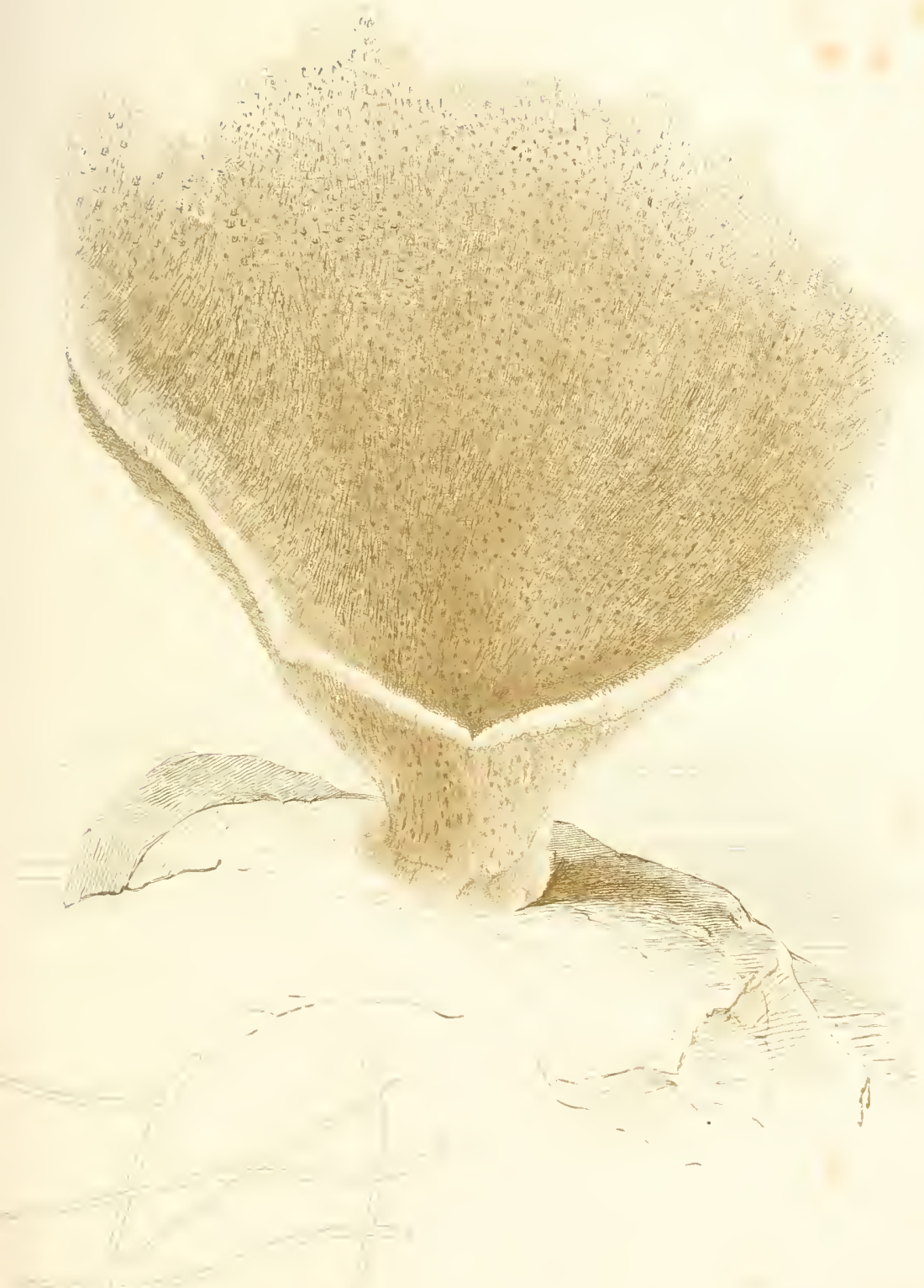



(n) 


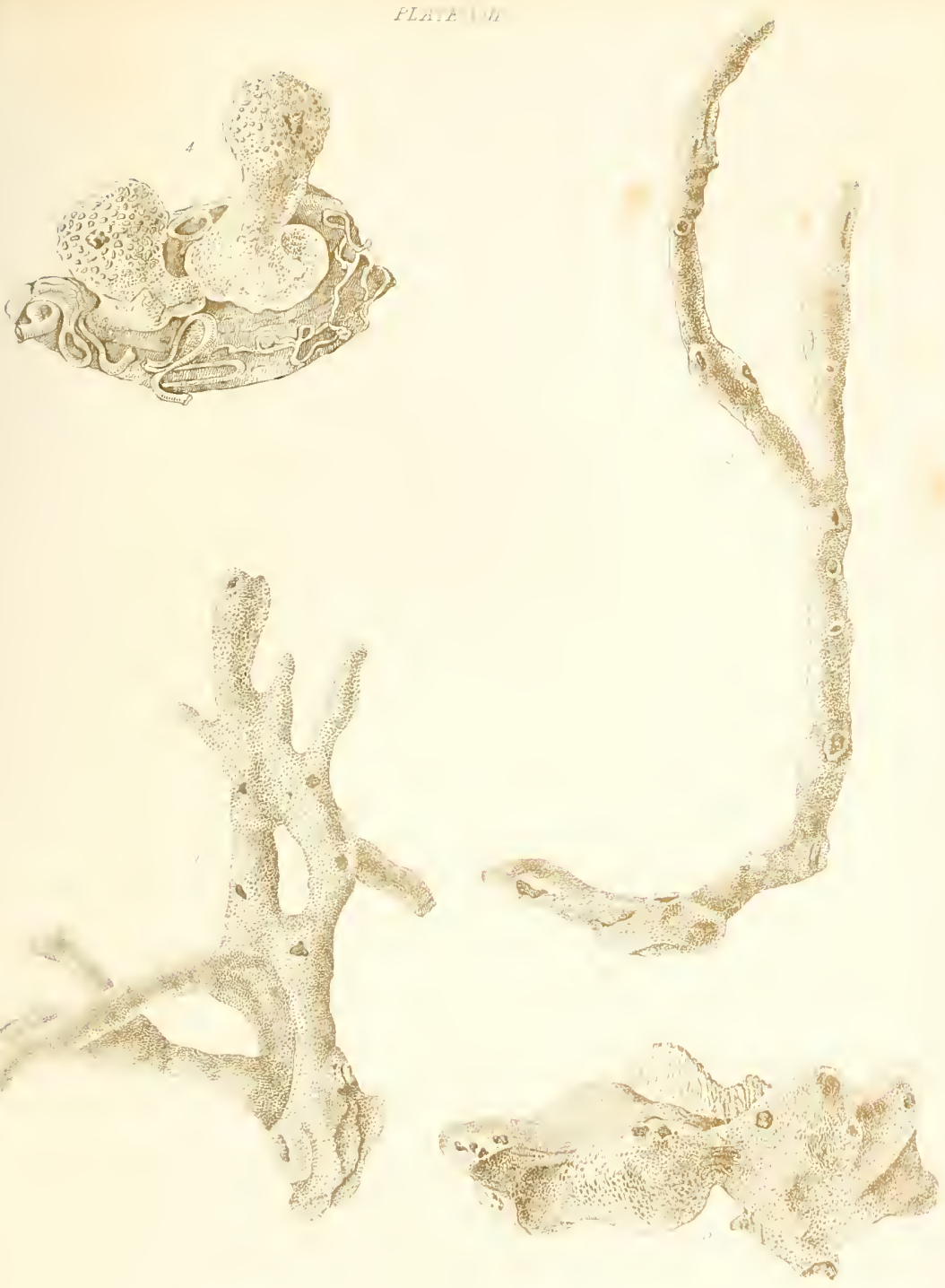

$\omega$
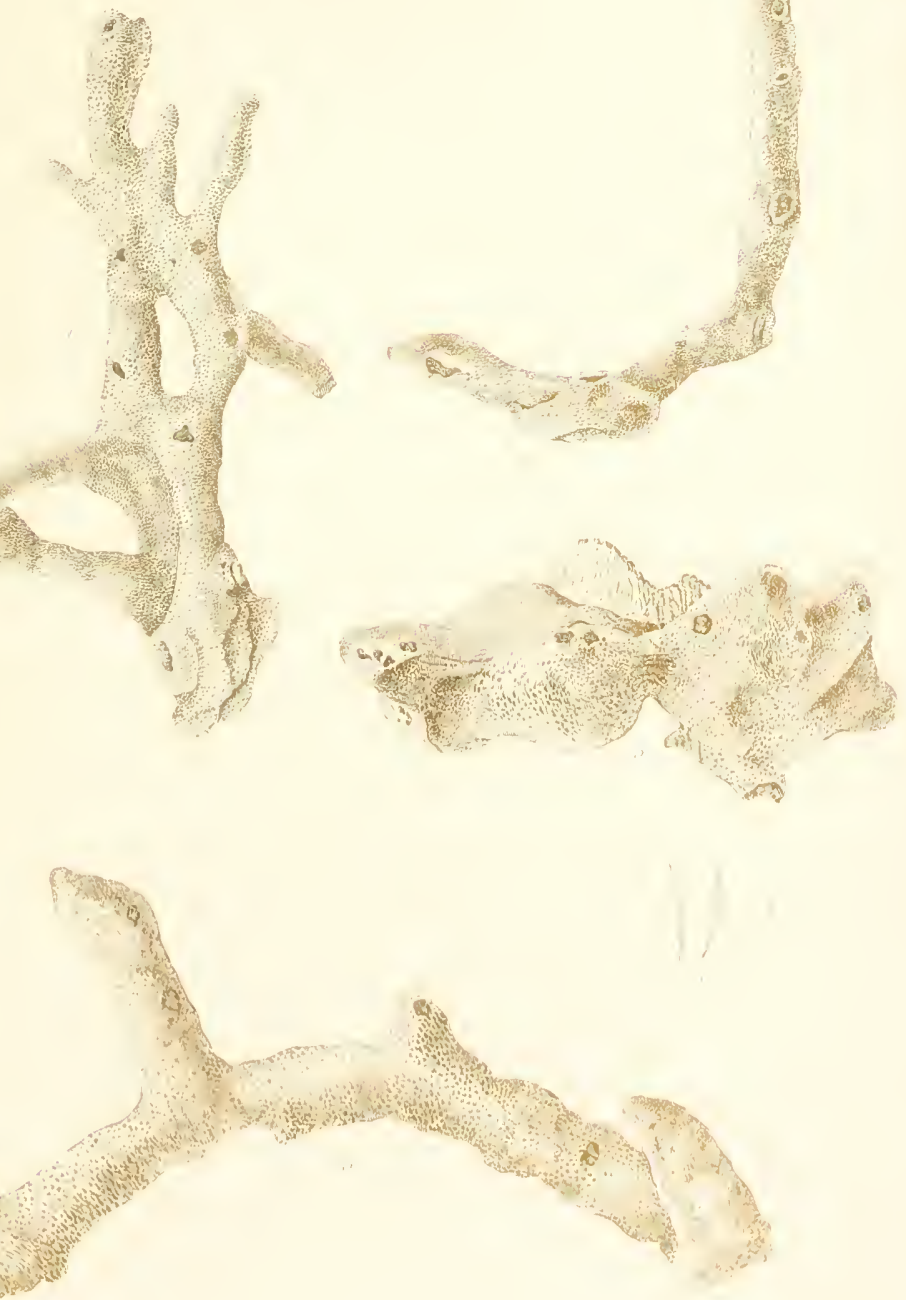




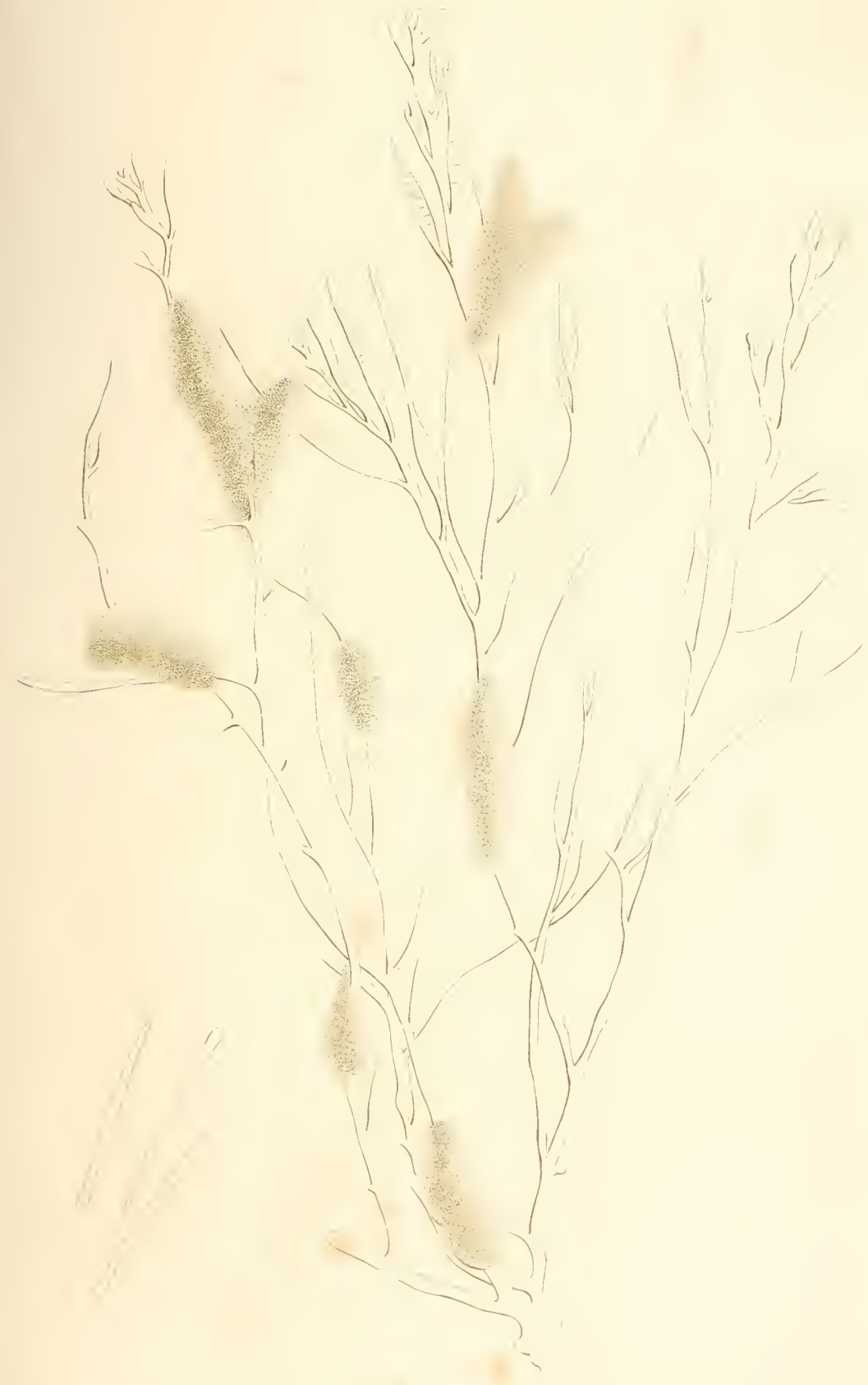





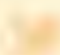

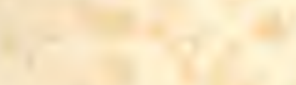

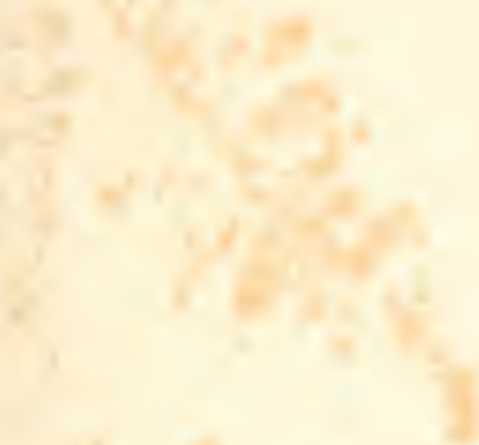

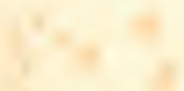

$\sqrt{2}+x^{2}$

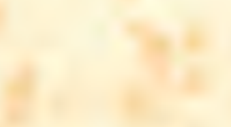

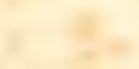

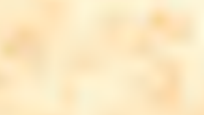

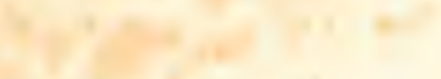



$(2) \sqrt{2}$

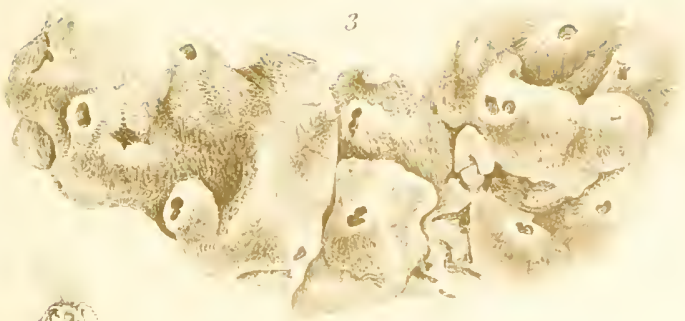

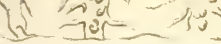
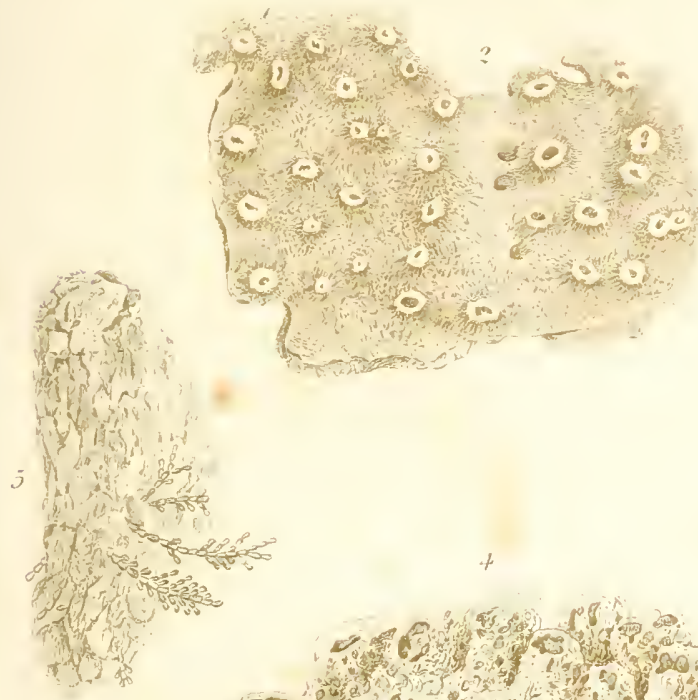

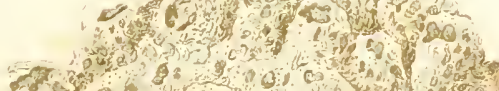

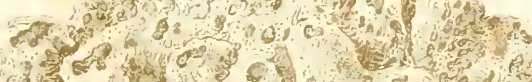

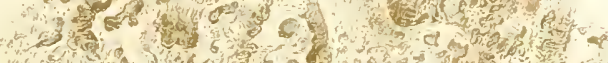

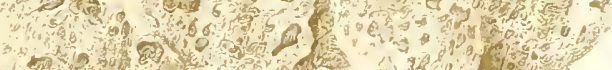

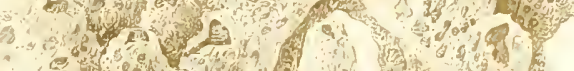

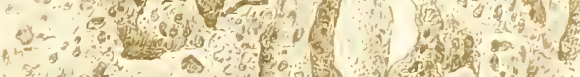

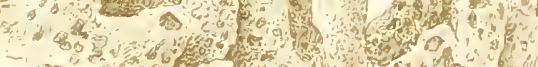
T e

$$
\text { of } 6 \text { ond }
$$

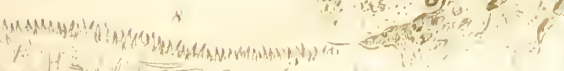
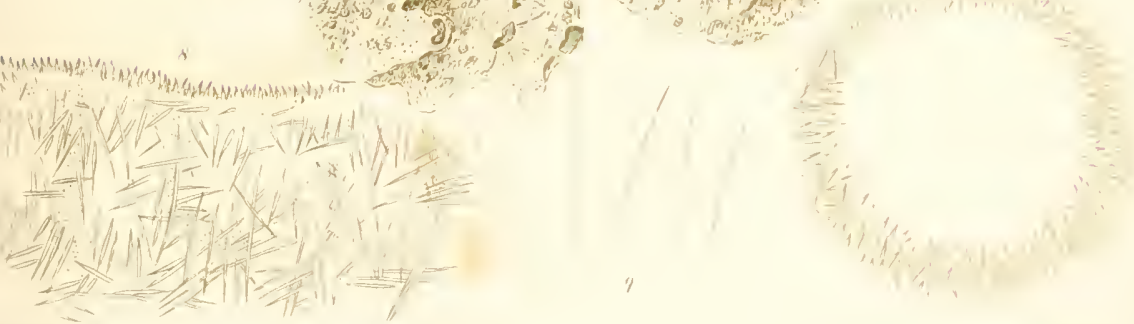




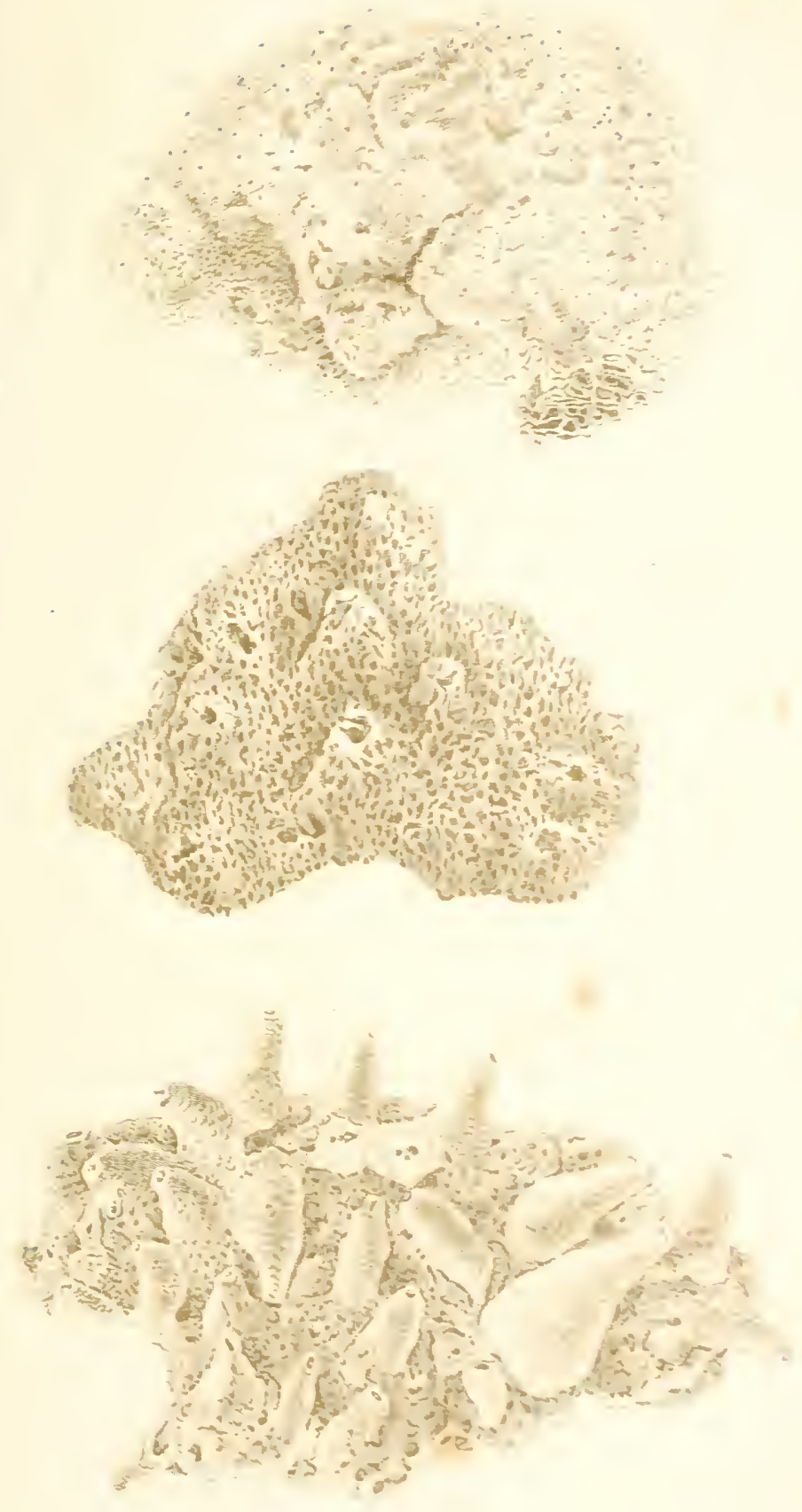






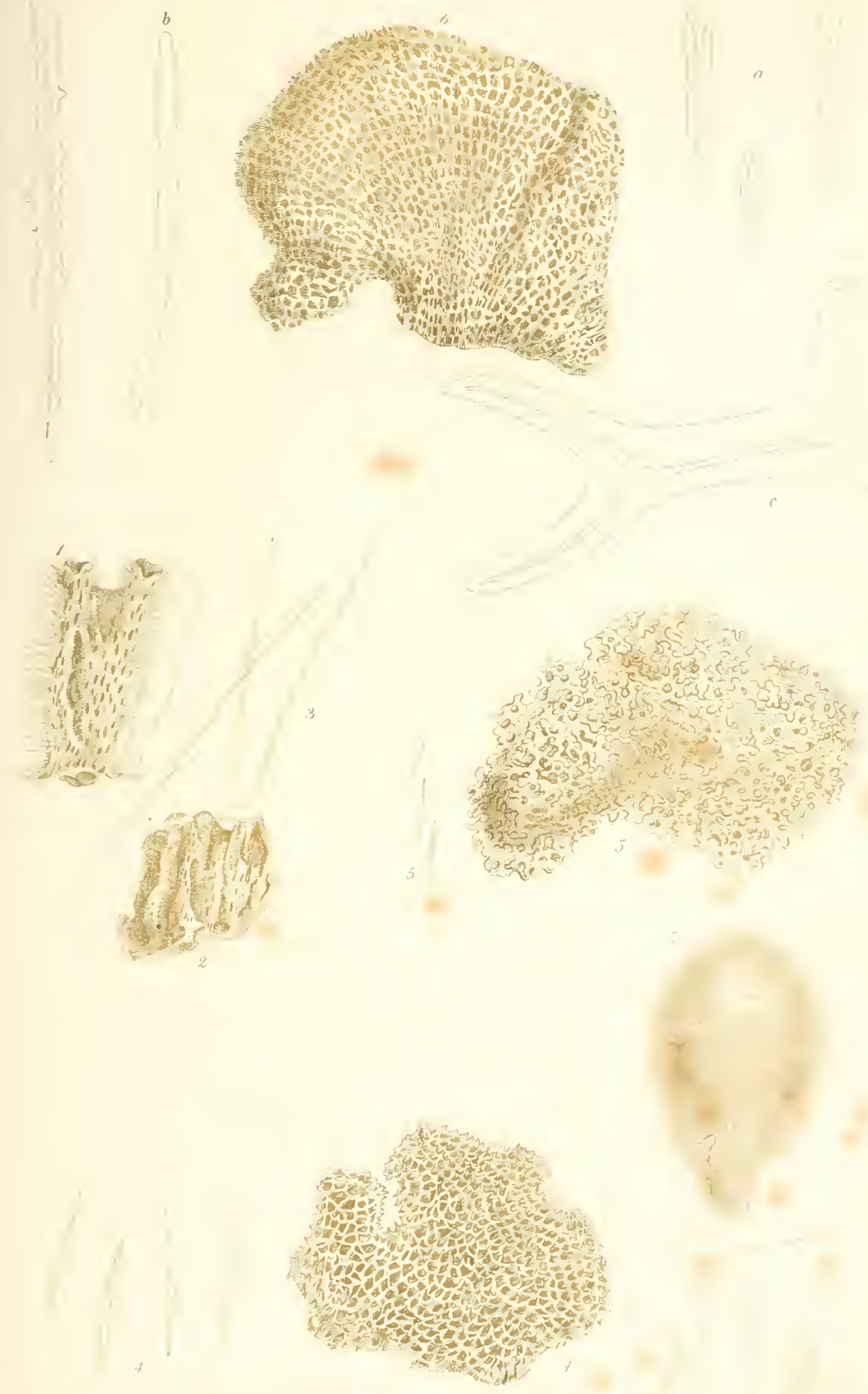



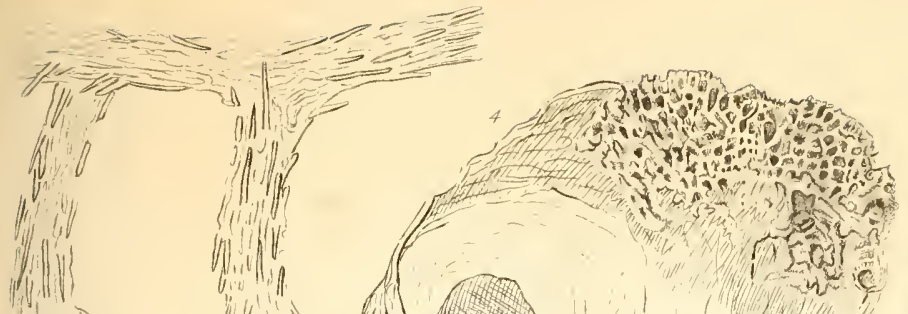

wiflili IIII

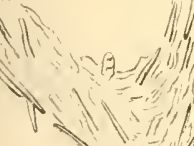

za
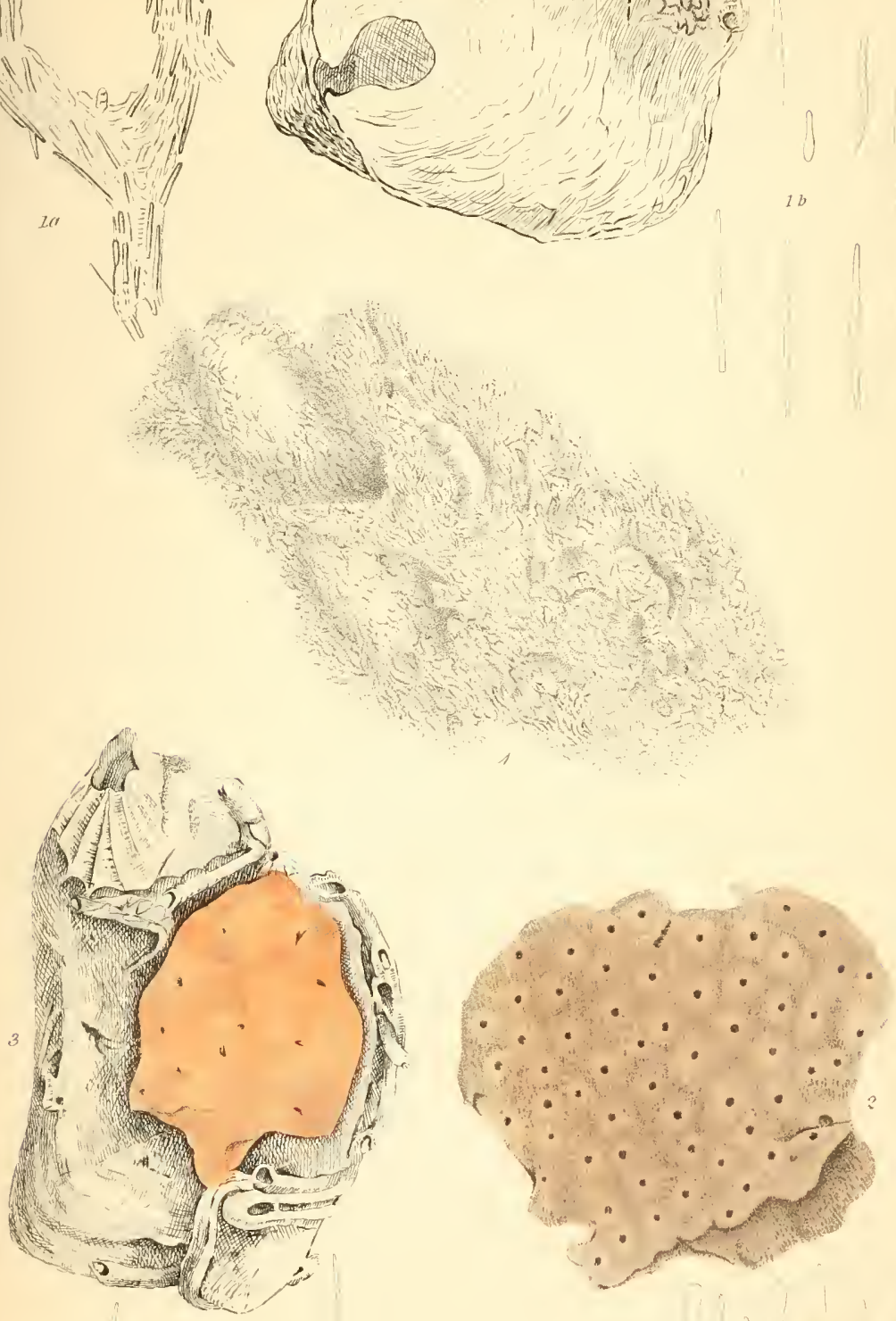




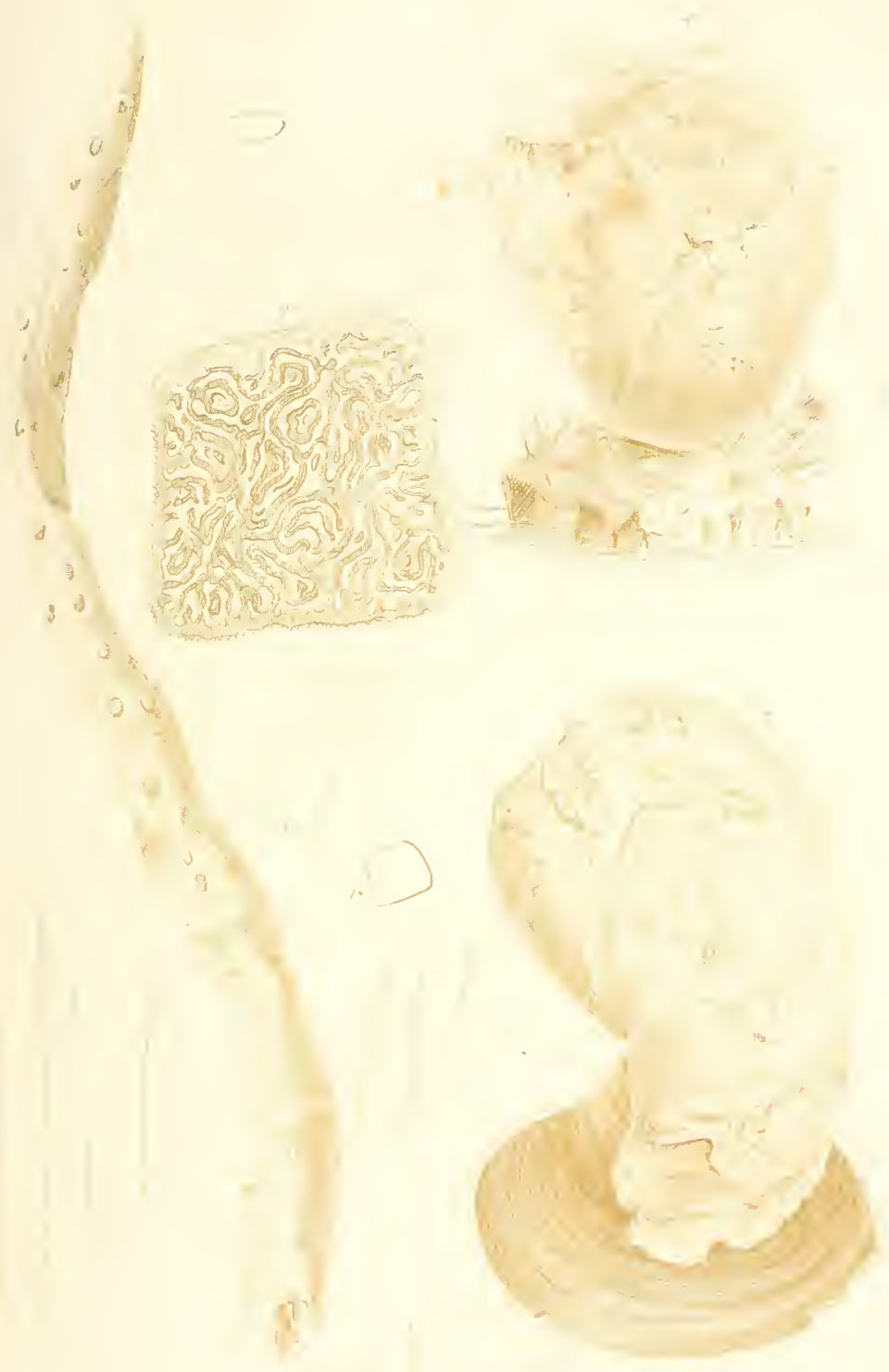




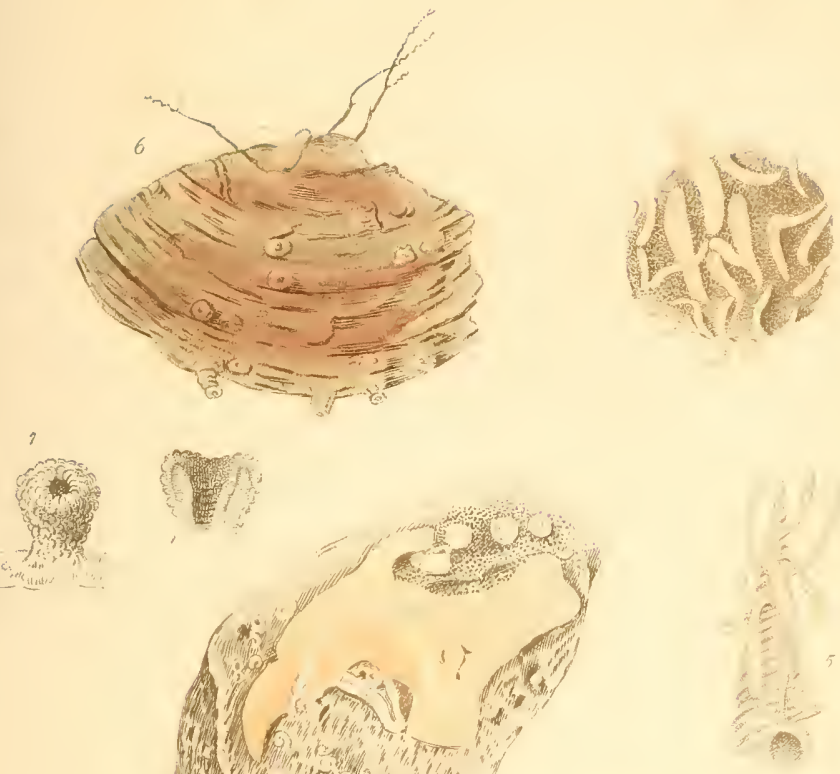

$102 x^{2}$

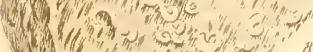

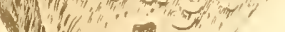

(4."

(1)

$(1,3), 5$
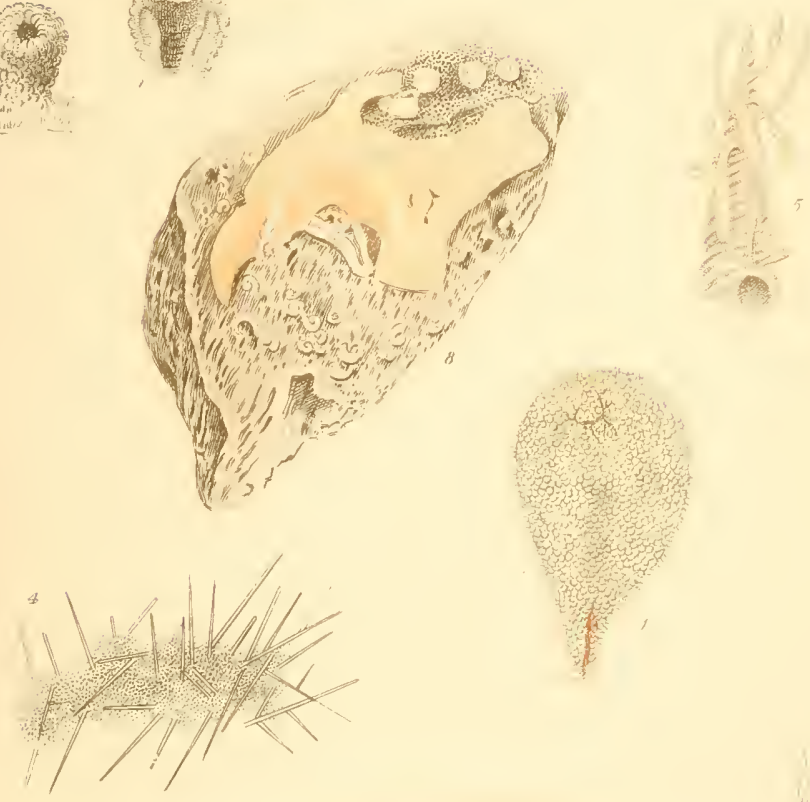




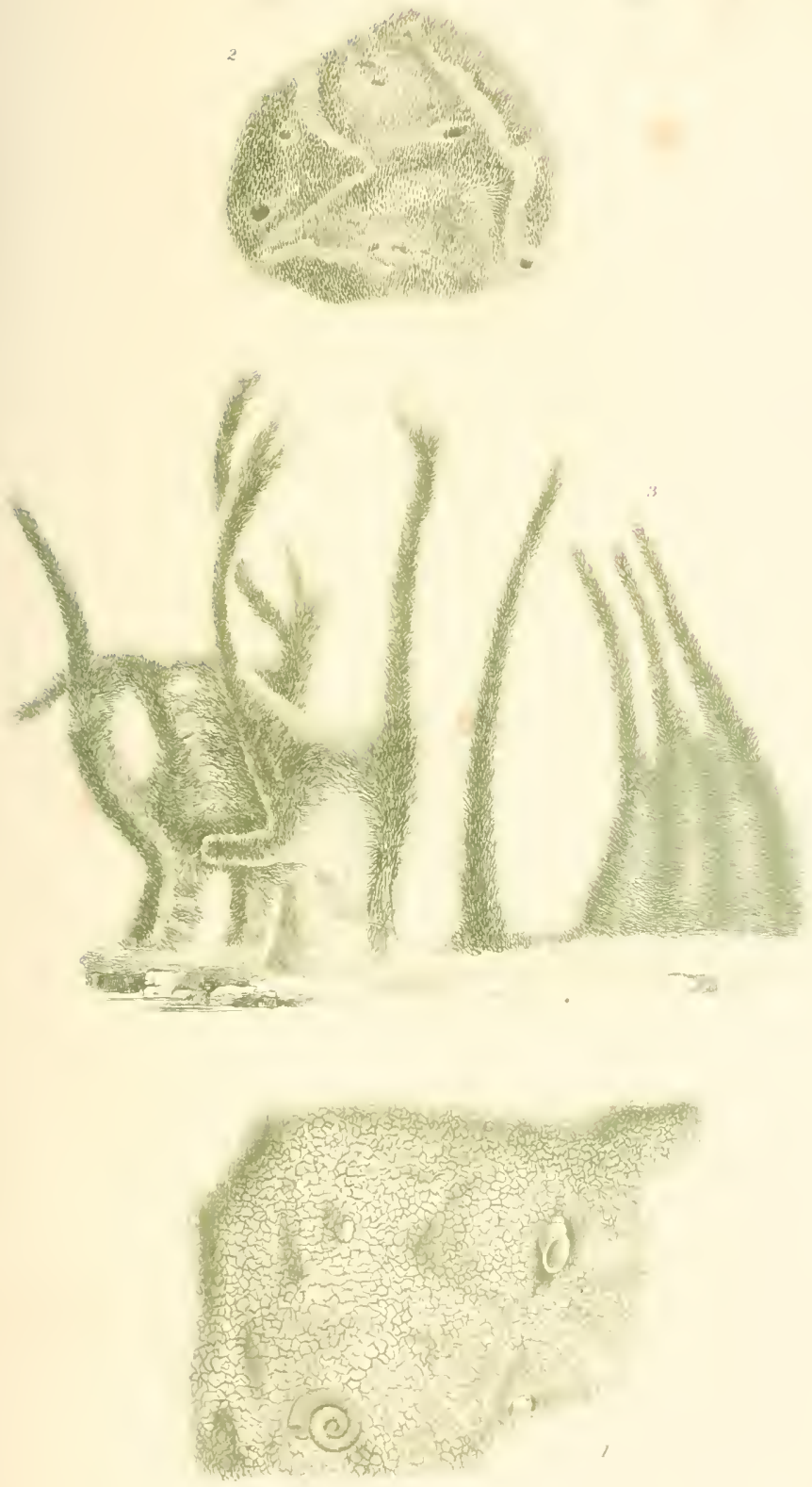





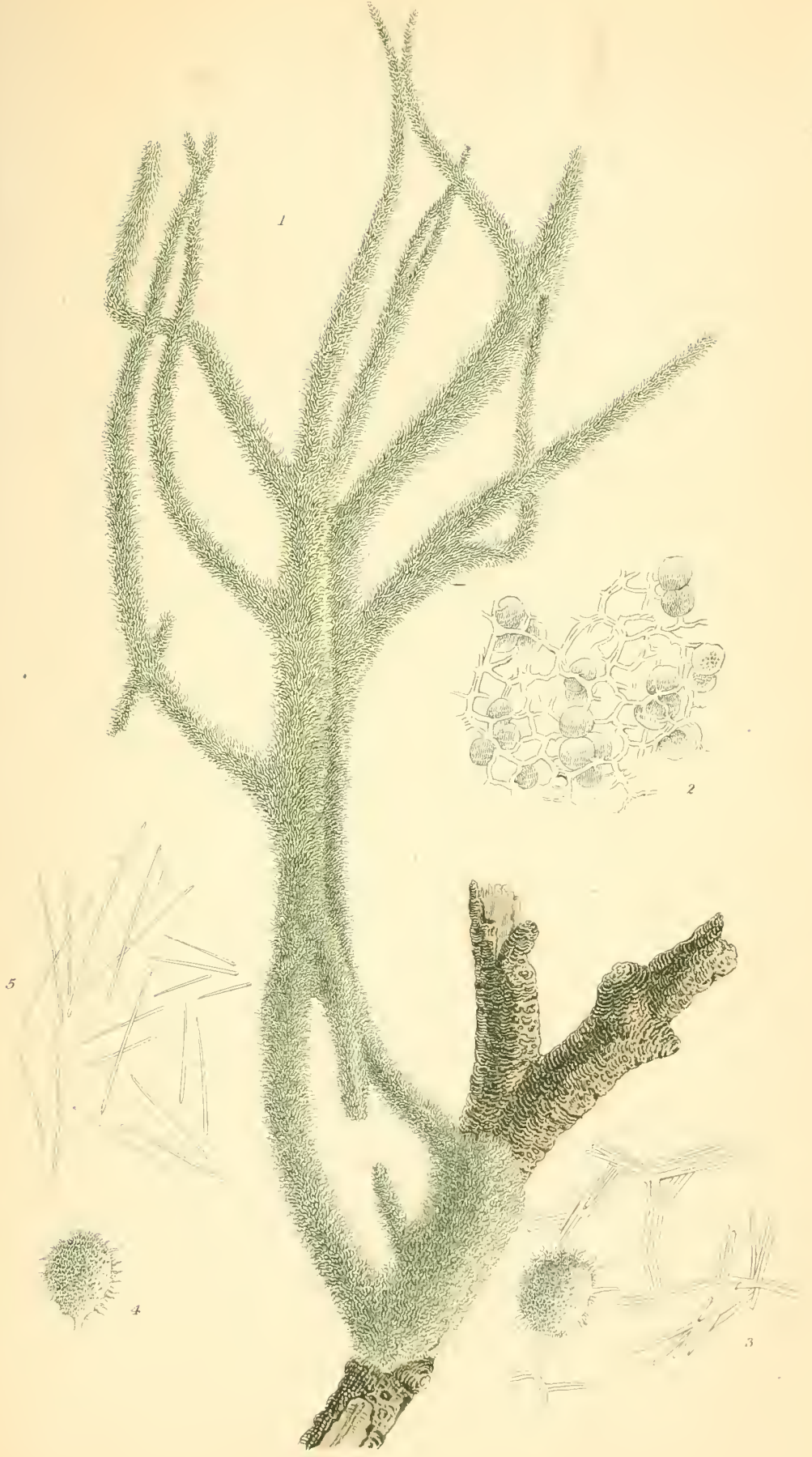





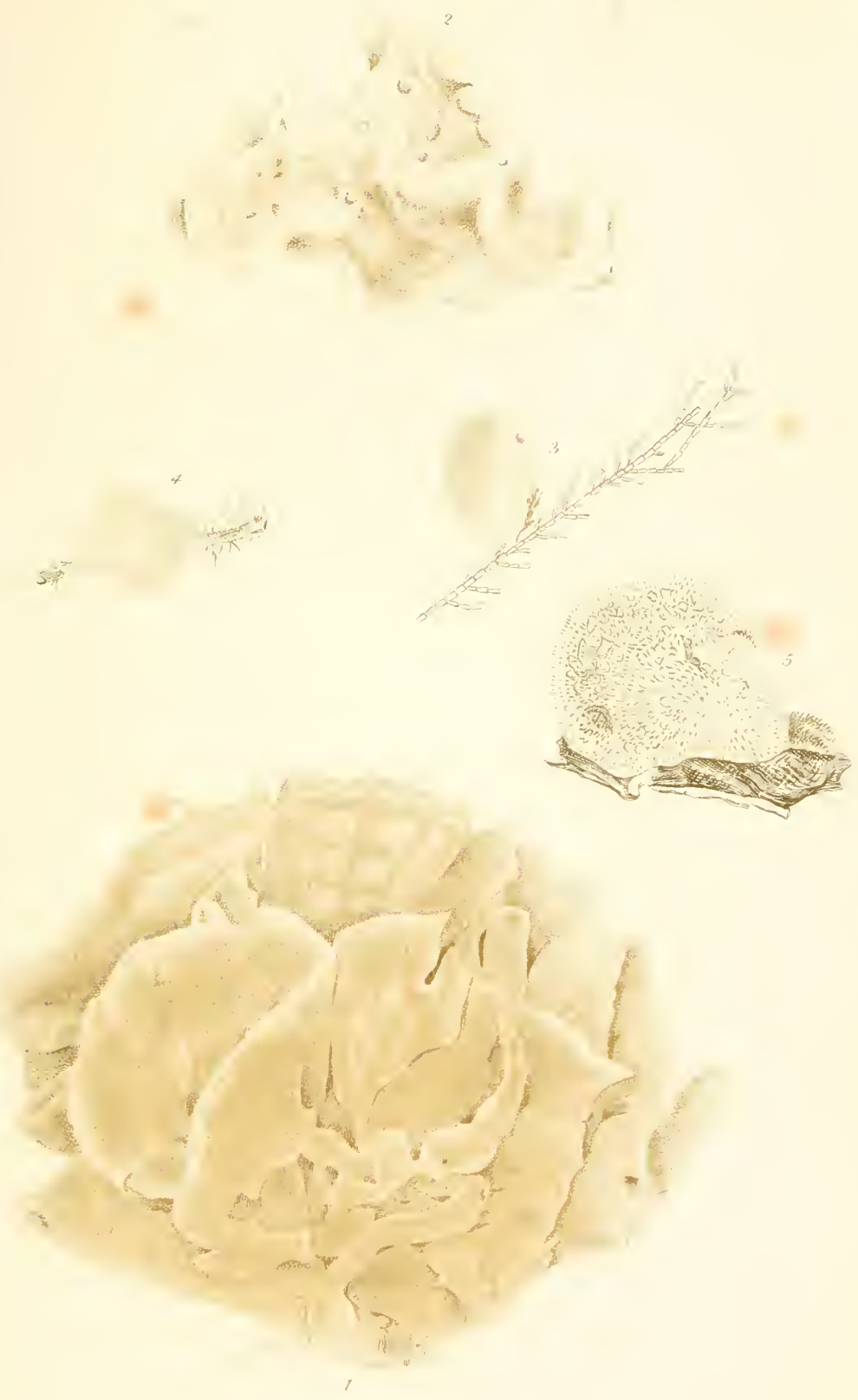






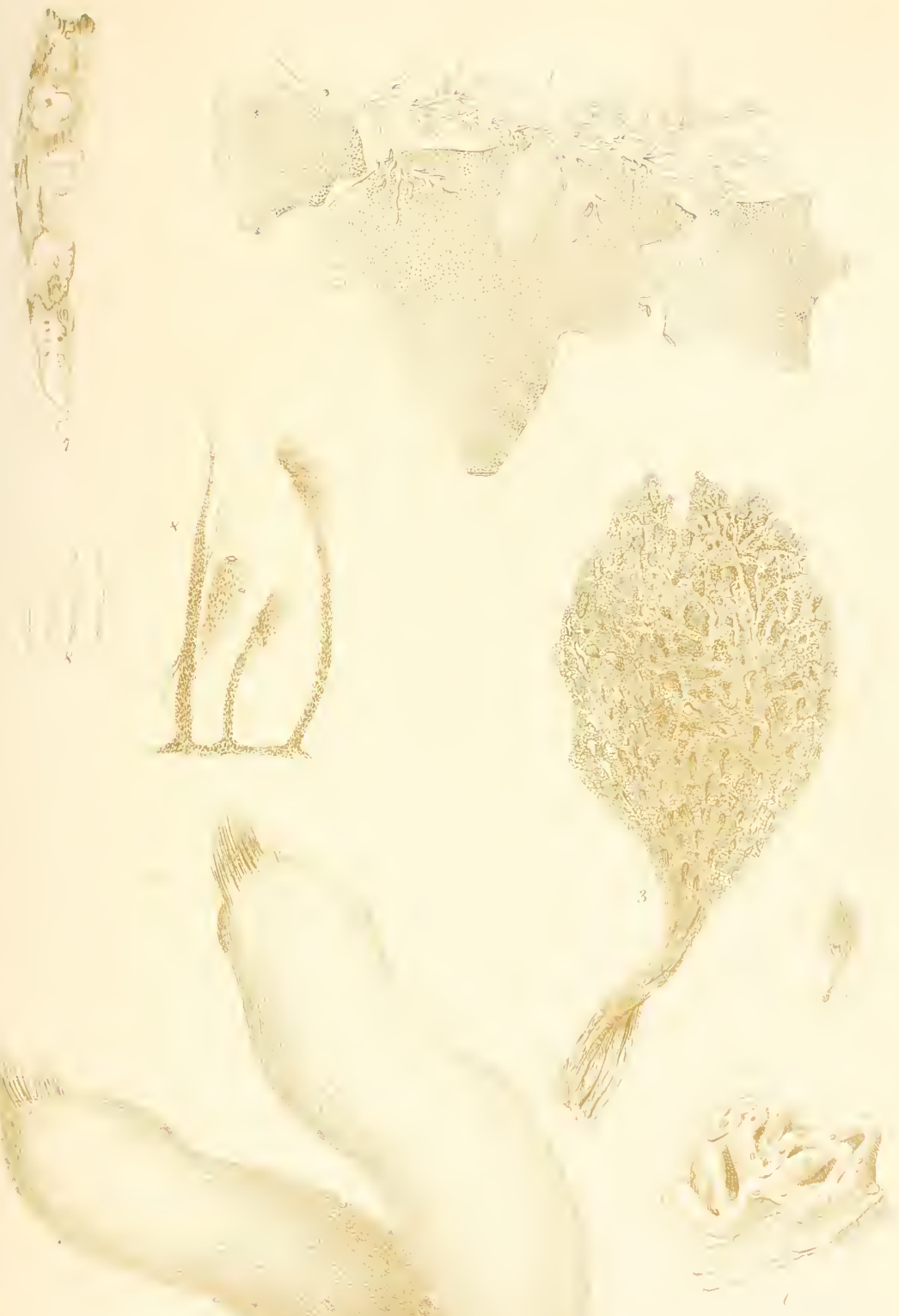

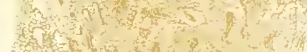

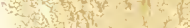

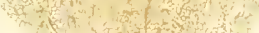
(n)

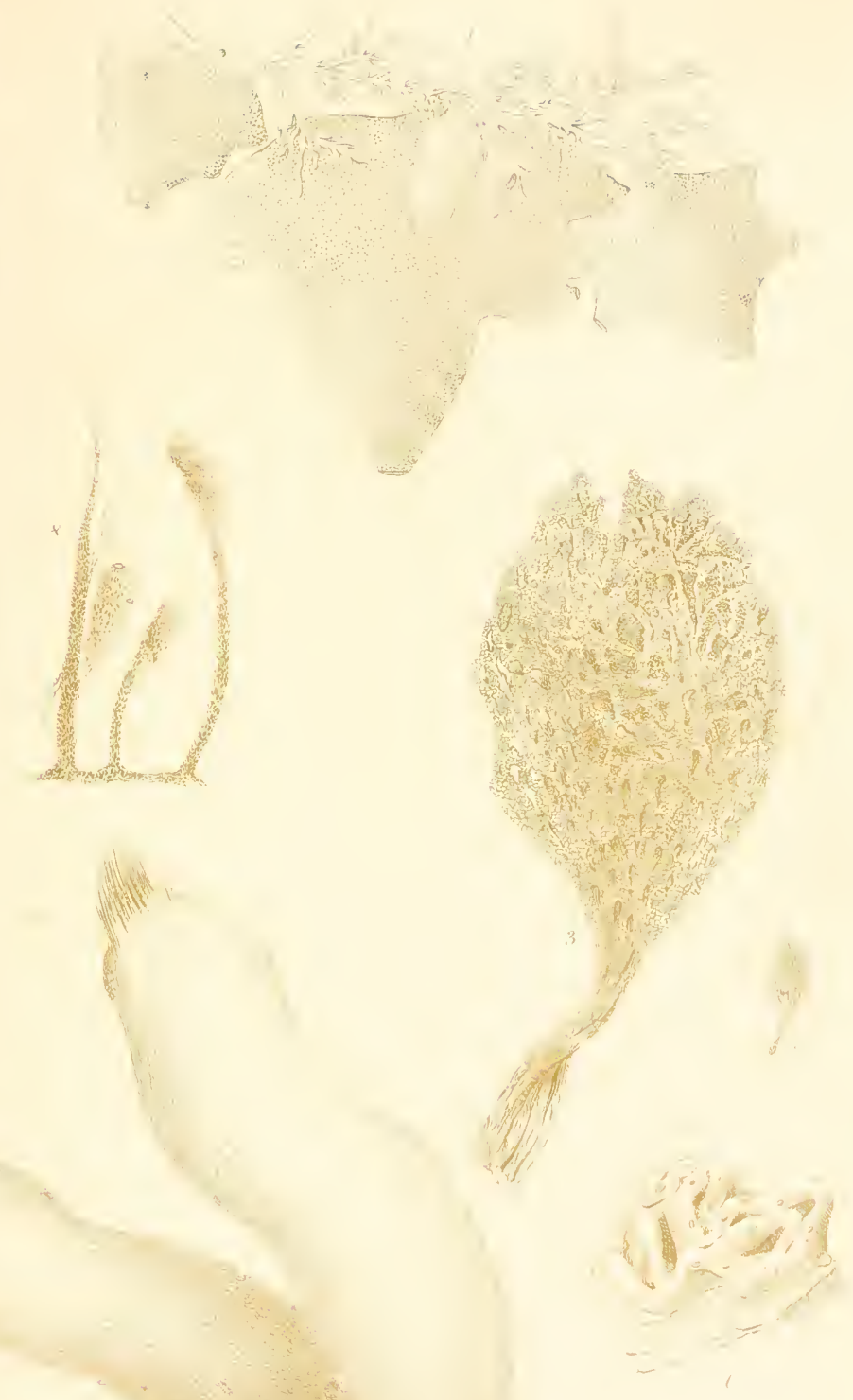

Mily!'in 




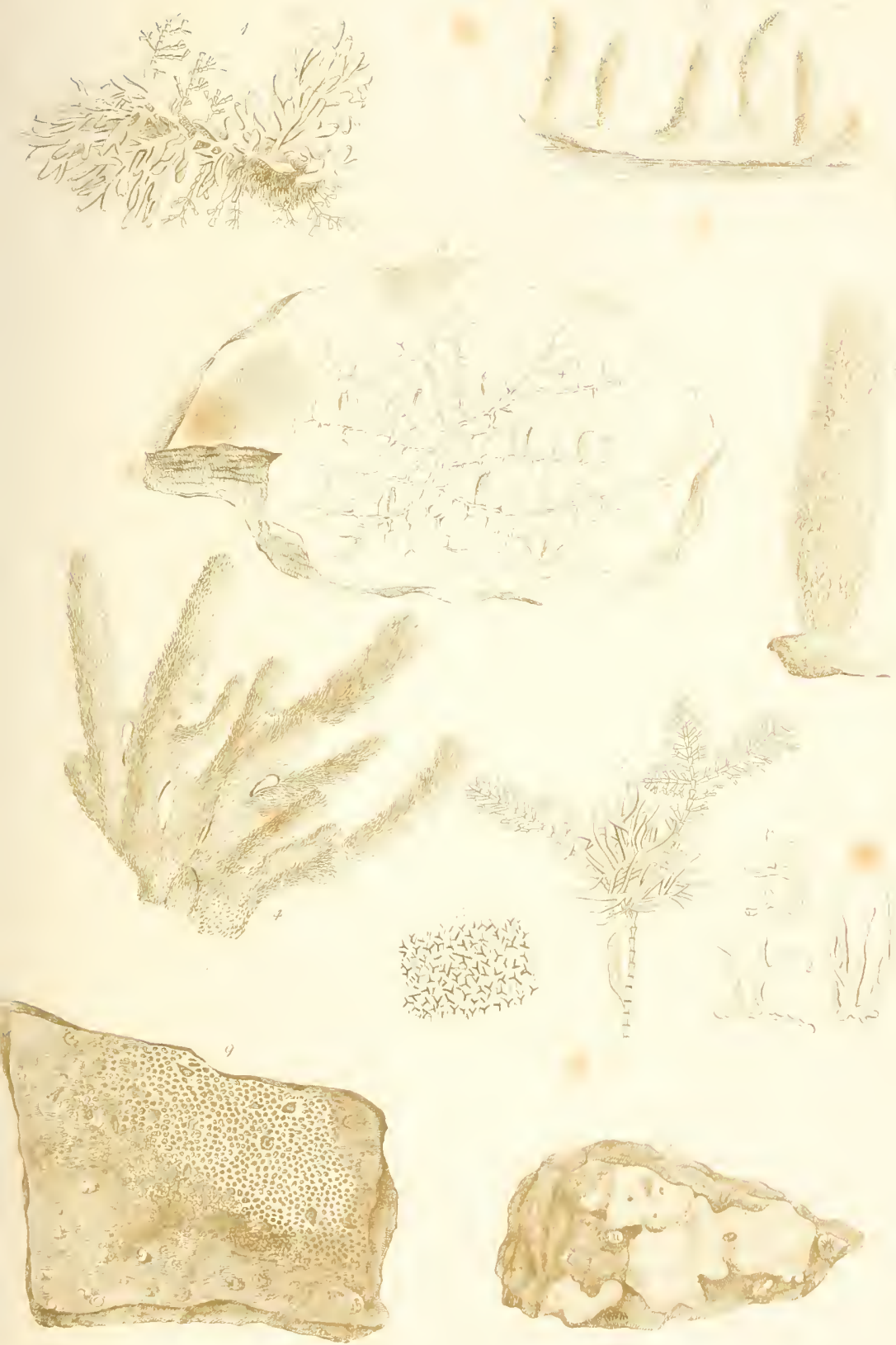




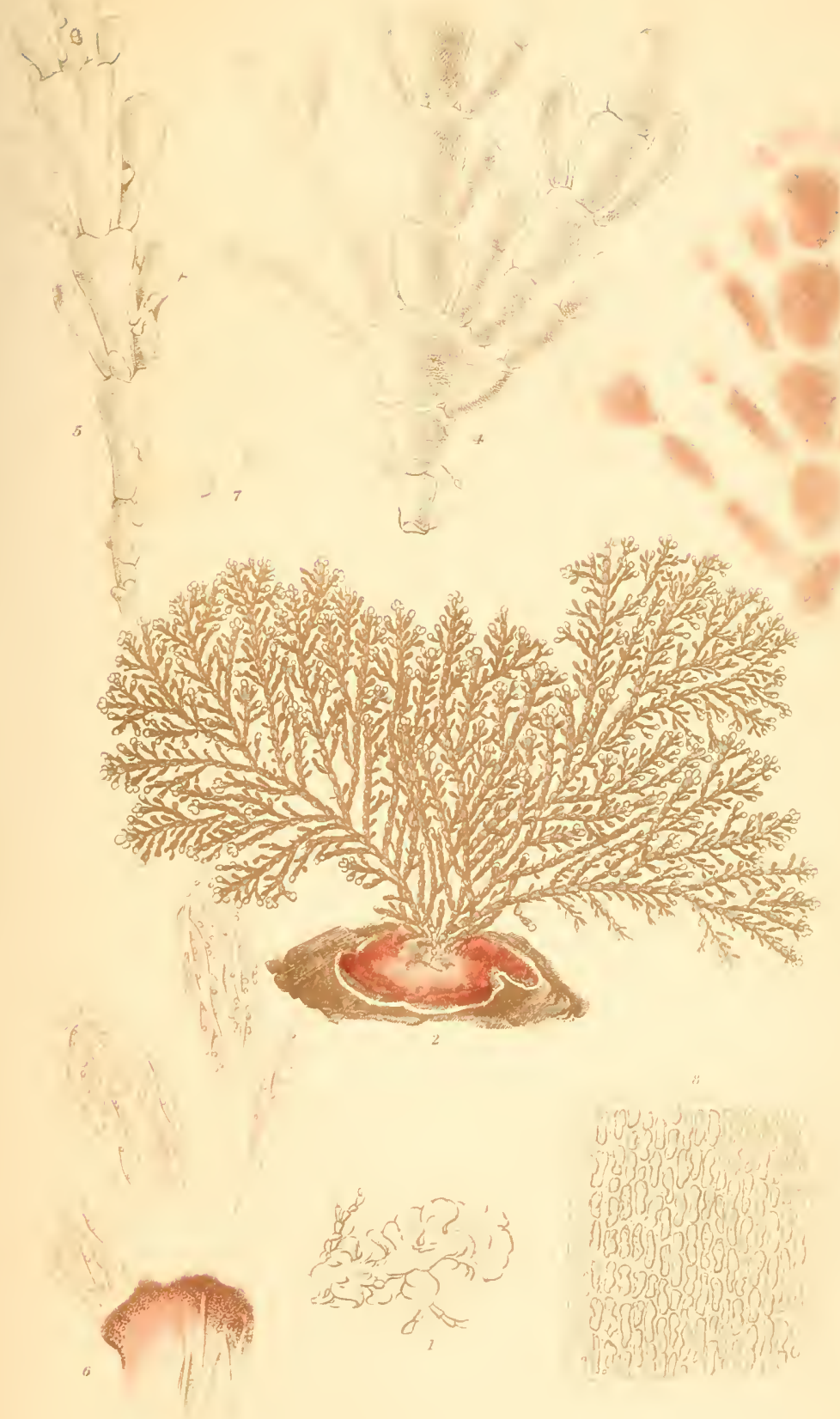







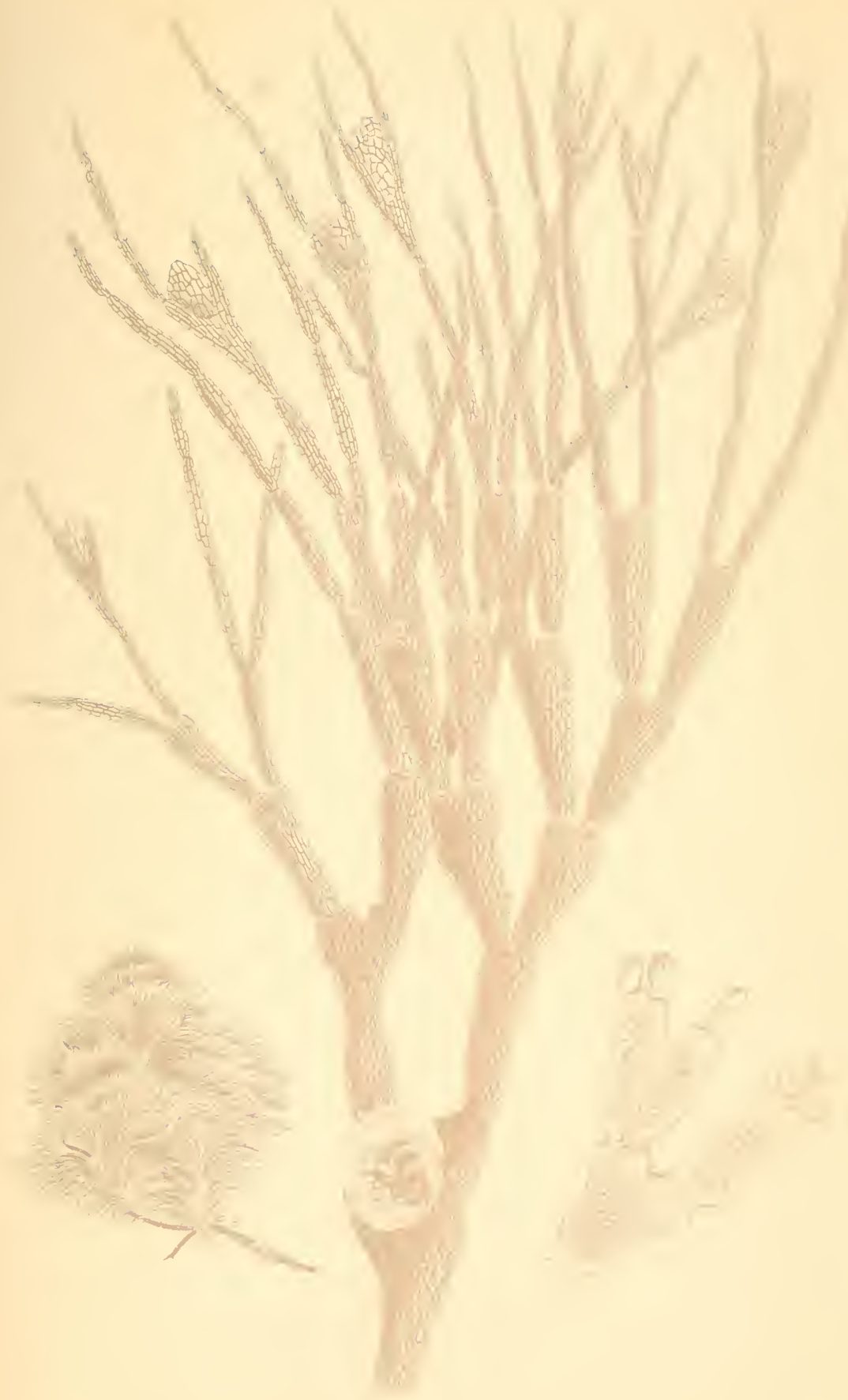






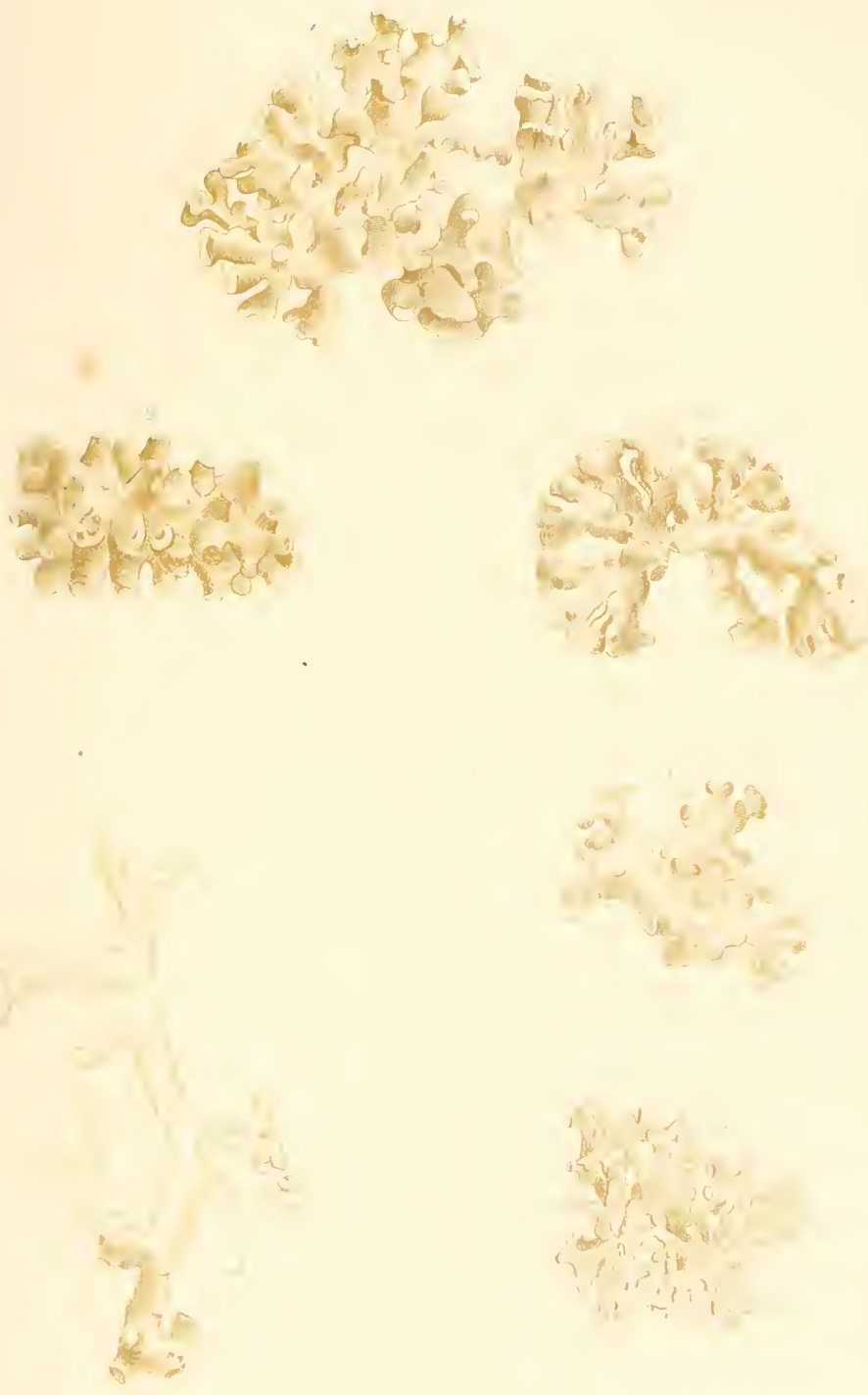




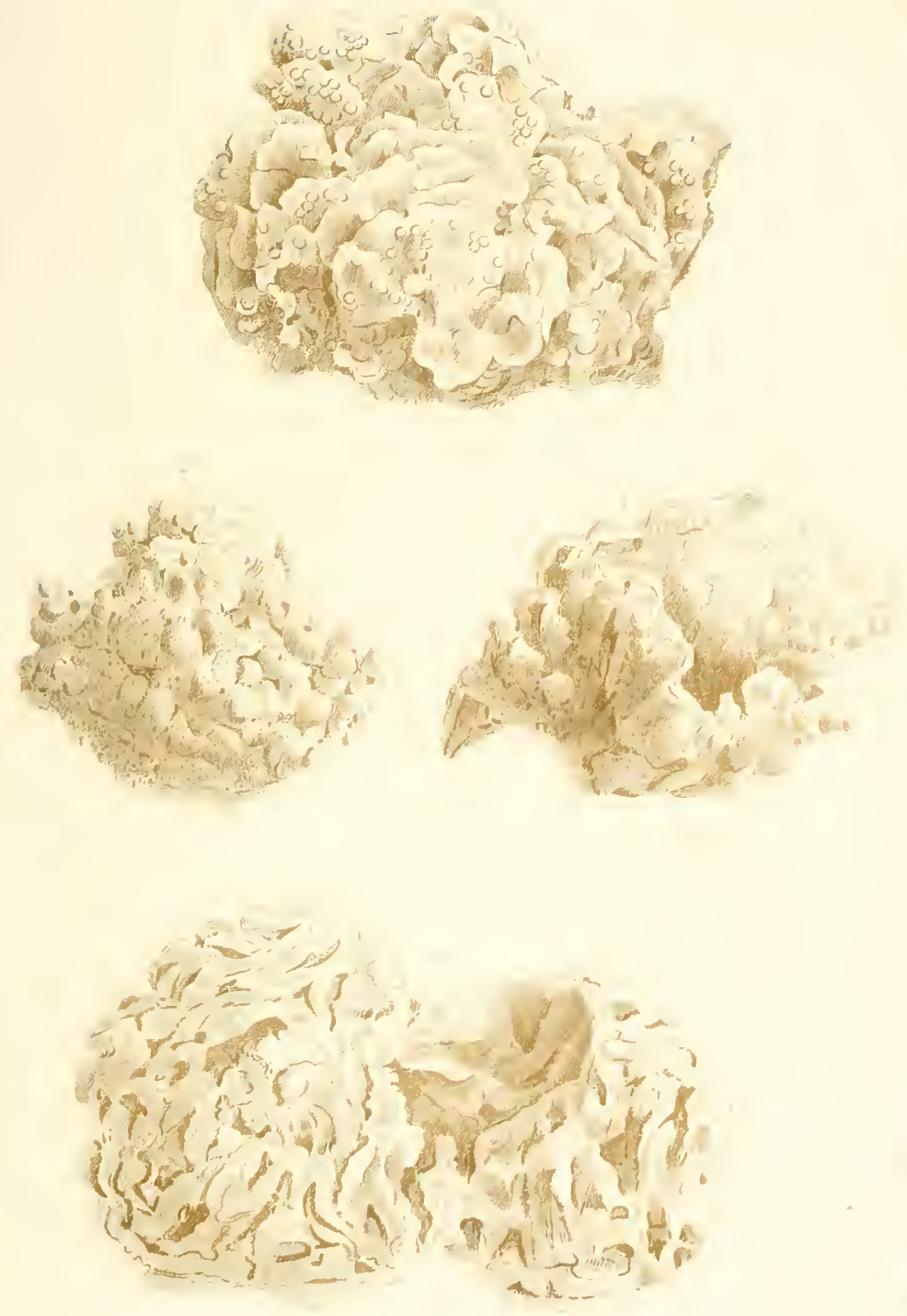





UNIVERSITY OF ILLINOIS-URBANA

\subsection{J64H COO2}

A HISTORY OF BRITISH SPONGES AND LITHOPH

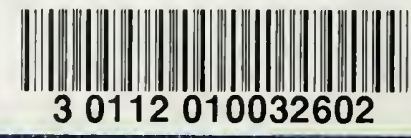

